\title{
Memory and Forgetting in the Nascent New Zealand Histories of James Cowan, Edith Statham and Horatio Gordon Robley
}

\author{
Lydia B. Whiting
}

\author{
A thesis \\ submitted to Victoria University of Wellington \\ in fulfilment of the requirements for the degree of \\ Master of Arts \\ in History
}

Te Herenga Waka Victoria University of Wellington 



\section{Abstract}

This thesis examines the nascent, early twentieth-century New Zealand histories created by James Cowan (1870-1943), Edith Statham (1853-1951), and Horatio Gordon Robley (1840-1930). It asks how their histories of the colonial past were shaped by their own experiences and by the contexts of the period c.1863-1940. In the early twentieth-century Cowan was a journalist, best known for his publication The New Zealand Wars (1922-23). Statham was an active volunteer in the Victoria League and then a government employee, dedicated to the work of refurbishing old soldier graves. Robley was a veteran of the New Zealand Wars residing in London, known for his ethnographic collecting, publications and artwork. This thesis considers how their work converged in efforts to preserve and narrate New Zealand's colonial history.

The discussion charts the lives and careers of these three history-makers through their publications, correspondence, manuscripts, reports and newspaper reports. It begins by situating each of the history-makers within the colonial era, considering their proximity to the events they would come to memorialise. The discussion then traces the three history-makers as they stepped into the new century, their work sitting within the tensions of belonging in New Zealand at this time. What they conveyed was both a sense of a belonging to a particular geographical and cultural locale, along with a strong allegiance to empire in wake of the Anglo-South African War and the death of Queen Victoria. The discussion then considers the era when all three focused in on the conflicts of the colonial period, beginning with Statham's soldier grave work from 1910 and ending with Cowan's publication of The New Zealand Wars in 1923. Funding this converging work was the New Zealand government. Preserving and narrating the history had gained public and political support, partly due to the sense of urgency that the generation who had fought in the wars was fast disappearing. The degree to which this historical work was considered valuable was underscored by both government funding and public interest at the same time as the country was facing a costly and confronting world war. The discussion then traverses their attempts to continue their historical work after 1923 and in the lead up to the 1940 centenary celebrations, a period when new forms of cultural belonging and modern scholarship moved away from those that had emboldened the work of Cowan, Statham and Robley decades earlier.

The nascent histories of Cowan, Statham and Robley represent a powerful and perplexing moment in the formation of New Zealand. They each narrated histories and public memories of and for 'New Zealand' in a particular context, one marked by both an intense attention to the local and a powerful imperial loyalty. Statham, having pursued a sense of progressive female citizenship in Dunedin, took up the commemoration of men who had died for empire as an extension of her public work. In doing so, Statham embodied the dichotomy of belonging in New Zealand. Cowan's candidacy for writing an official New Zealand War history was due to his proximity to those informants who were still alive at the end of the Great War. Cowan hoped to cultivate a habit of remembering actors and events of New Zealand's colonial past, but by rendering past conflict as resolved in the present, he only enabled the lapse into forgetting thereafter. Despite his London locale, Robley was intimately tied to New Zealand activities and aspirations over a span of 30 years. Robley was both an actor in the colonial past and a creator of its historical renderings, demonstrating that these nascent New Zealand histories were not just produced in New Zealand. 


\section{Acknowledgements}

First and foremost, I thank my supervisors Professor Charlotte Macdonald and Dr Arini Loader. Their guidance and critique sharpened my arguments and I am grateful for their unwavering support and encouragement throughout my postgraduate experience. My gratitude is due to the friends of Annette E. Black who established a scholarship fund in her memory, making it financially possible for me to complete this research that I enjoy so much. I am also appreciative of Victoria University for helping meet the costs of research trips.

To the wider Victoria University History Programme, I am grateful for the meaningful engagement throughout my undergraduate and postgraduate studies, especially the teaching staff who affirmed my excitement for history by providing such stimulating undergraduate courses from when I began in 2015. I am thankful to those in the Department who have supported me this year, both academically and personally, particularly my MA cohort, Maggie, Tommy, and Beth.

I greatly appreciate the work of the archivists, librarians, and curators at the various institutions. To Sue at the J.C. Beaglehole Room I am grateful for not only the assistance this year, but for years of advice and assistance in both academic and professional queries. I thank Helen Stevens and the staff at the Sir George Grey Special Collections at Auckland Library. Multiple lockdowns and a faulty roof almost kept me from some important records, but Helen was able to organise their retrieval despite the odds.

I am grateful to my parents for their immense support. I could not have asked for better company on my drive down the Great South Road than my father Glenn, who was largely responsible for making it the beneficial trip that it was, and my mum Michele who has always been so engaged in my work. I thank George, Lesa, Sylvia and Ash who have provided the necessary downtime and laughter, and Cashill for all the dinners delivered, the encouragement and the company during late nights in the office. Finally, I am grateful to my niece Frida, for reminding me to come back to the present every once in a while. 


\section{Table of Contents}

$\begin{array}{lr}\text { Abstract } & \text { i } \\ \text { Acknowledgements } & \text { ii } \\ \text { List of Abbreviations } & \text { iv } \\ \text { List of Figures } & \text { v }\end{array}$

Introduction $\quad 1$

Chapter One Inroads to Maoriland: Personal Experience, Nostalgia and Situating Self Within the Colonial Period, 1863-1901

Chapter Two Maoriland in the Shadow of a Matriarch: Cultural Locality and Imperial Belonging in the New Century, 1901-1914

Chapter Three 'Propelled by Change to Organise the Past':

Perfecting the Narrative of Colonial Memory, 1914-1923

Chapter Four History, Modernity, and the Forgetting of

Settlement, 1923-1940

96

Conclusion 


\section{List of Abbreviations}

\section{Newspapers}

Auckland Star AS

Evening Post EP

Evening Star ES

New Zealand Herald $\quad$ NZH

New Zealand Times $\quad$ NZT

$\begin{array}{ll}\text { Otago Daily Times } & \text { ODT }\end{array}$

Otago Witness $\quad$ OW

\section{Journals and Periodicals}

Dictionary of New Zealand Biography DNZB

Encyclopedia of New Zealand $\quad$ Te Ara

Journal of New Zealand Studies $\quad$ JNZS

New Zealand Journal of History $\quad$ NZJH

\section{Archives and Collections}

Alexander Turnbull Library, Wellington ATL

Appendices to the Journal of the House of Representatives AJHR

Archives New Zealand, Wellington $\quad$ ANZ

J.C. Beaglehole Room, Victoria University of Wellington JCBR

Sir George Grey Special Collections, Auckland City Library, Auckland G GSC 


\section{List of Figures}

Figure 1: 'Paul Kruger, president of the Transvaal', c. $1900 \quad 40$

Figure 2: ‘Hon. R. Seddon’, c. 1890

Figure 3: ‘To Be Erected in Auckland', Auckland Weekly News, 18 June 1914

Figure 4: 'War memorial on the corner of Wakefield and Symonds Street, Auckland' 68

$\begin{array}{ll}\text { Figure 5: ‘Maorilander’s Greeting to Kaiser Bill’, c. } 1914 & 71\end{array}$

Figure 6: Map of Edith Statham's New Zealand War Memorials $\quad 75$

Figure 7: James Adam Capper and Hekeria Te Rangi, 1 April 1914

Figure 8: Rangiriri Memorial Gateway Inscription $\quad 100$

Figure 9: 'Rangiriri: Unveiling ceremony after reconstruction in 1926’ 101

Figure 10: ‘James Cowan, with a moko drawn in pen’’ 124 


\section{Introduction}

On a blustery Wellington afternoon in April 1934, a crowd gathered in front of the halfcompleted façade of the long-awaited new Dominion Museum and National Art Gallery building. The site was perched upon a small, panoramic hilltop in the suburb of Mount Cook, providing an unobstructed sweeping view of the harbour, downtown and the surrounding suburbs. It is unsurprising, especially given the classical pillar design in the midst of construction, that the site would come to be seen as an 'acropolis' for the city of Wellington. ${ }^{1}$ Beneath a wind-swept string of union jacks, St. George crosses and southern constellations, the congregating onlookers observed the Governor General of New Zealand, Lord Bledisloe, lay the foundation stone of the new building. Through loud speakers perched upon the scaffolding Bledisloe addressed the crowd with the hopes 'that [I] might be deemed in the eyes of posterity to have laid the foundations, not only of a prospectively noble structure of striking architectural beauty and skillful internal arrangement but also and chiefly of a new - more stable and more coherent national fabric of higher education and cultural expansiveness... a solid pillar which would ever uphold a monolith of intellectual progress.' ${ }^{2}$ The building was the long awaited result of the plans put forth by the Science and Art Act 1913 to create a combined national institution for the nation's museum and art gallery, a place of prestige. ${ }^{3}$ The Act had formally incorporated the institutions under one piece of legislation, with a long term plan to have them eventually under the same roof. It had also stipulated that these government institutions would be the place for the systematic acquisition of 'articles and documents of scientific, artistic or historical value to be kept and exhibited therein respectively. ${ }^{4}$ Bledisloe's statements expressed the sentiment of a country that had been shaped, and would continue to shape, its past as a measure of its progress into the future.

The ceremony for the new museum and gallery was small in comparison to the dedication for the Carillon National War Memorial that towered over the city at the front of the Mount Cook site, which had taken place less than two years earlier. On 25 April 1932 thousands swarmed the streets surrounding the monument to watch Bledisloe switch on the 'lamp of remembrance' at the top of the Carillon tower, marking 16 years since Dominion troops landed at Gallipoli in what would be the defining battle of New Zealand's First World War experience. ${ }^{5}$ When the total site was completed in

\footnotetext{
${ }^{1}$ Conal McCarthy, Exhibiting Maori: A History of Colonial Cultures on Display, (Oxford: Berg, 2007), p.75.

2 'Pillar of Progress: New Dominion Museum', Hawera Star (HS), 14 April 1934, p. 9; 'Saturday's Ceremony', Evening Post (EP), 16 April 1934, p. 7.

${ }^{3}$ Science and Art Act, 1913, 4. GEO. V. No. 22;

http://www.nzlii.org/nz/legis/hist_act/saaa19134gv1913n22196/; accessed 26 January 2021.

${ }^{4}$ Ibid.

${ }^{5}$ Sydney Charles Smith, 'The dedication of the National War Memorial, the Carillon, in Wellington', 25 April 1932, 1/1-020293-G, Alexander Turnbull Library, Wellington (ATL); Jock Phillips, To the Memory: New Zealand's War Memorials, (Nelson: Potton and Burton, 2016), p. 151.
} 
1936, it stood as a transcendent monument to New Zealand memory: repositories filled with ethnological and other scientific collections, fine arts, and a conspicuous reminder of the recent and bloody sacrifice in what had come to be termed the Great War. The site had been set in motion in 1919, by the commitment made by the Department of Internal Affairs of $£ 100,000$ to an eventual national war memorial project. ${ }^{6}$ It suggests that without the urgency of Great War remembrance, the stipulations of the 1913 Act might have continued to languish. But in 1919 the Department was not just concerned with commemorating the recent past, it had also been funding two other memorialising and textualizing ventures of a more distant, colonial past. From 1913 the Department had paid Auckland resident, Edith Statham, $£ 65$ per annum to refurbish the gravesites of old soldiers and pioneers, and to erect memorials across the North Island where these soldiers had died fighting against Māori during the wars of the colonial period. ${ }^{7}$ From early 1918, the Department had agreed to pay journalist and writer James Cowan $£ 300$ per annum for two years to write a comprehensive history of the nineteenth-century wars. ${ }^{8}$

In 1919 Statham and Cowan came together in correspondence about their memory work, not just with each other but with veteran of the wars in New Zealand, Horatio Gordon Robley (then living in London). On 18 June, Statham wrote to Robley, addressing the triangular pathways of correspondence between the three: 'I was glad to hear from you, and am sending on your letter to James Cowan, I regret much that I have not yet had the pleasure of meeting him, have just missed him in my travels, I hope to do so when I return to Wellington in a few months [sic] time.' ${ }^{9}$ Statham's letter had followed a similar report from Robley to his friend and bibliographer Horace Fildes earlier in the year, that 'it is James Cowan [who] has the order to go ahead with the Wars History '45 till [the] last scrap in NZ. I have written him some notes, on my time - his style will be different from Percy Smith. I also [heard from] Mrs. [sic] Statham of the Internal Affairs Office [who] wrote me [that] the cemeteries and graves are all seen to now. ${ }^{10}$ Separated by time and place, this correspondence in 1919 brought Cowan, Statham and Robley together in acknowledgement of one another's work. But it was far from the first or last time that they would cross each other's paths.

This thesis charts the trajectories of these three people, from the moment of their 'arrival' in New Zealand in the nineteenth-century and across their working years until their work slowed in later life, from c. 1863 to 1940 . The discussion is particularly centered around the period of engagement in the work that I term 'history-making’ or the formalising of colonial memory. This spans the period from

\footnotetext{
${ }^{6}$ N.A. Park, 'Memorandum for the Honourable Minister of Finance', 9 March 1932, 'National War Memorial, Art Gallery and Dominion Museum 1928-1934’, ADRK 17391, Record Group T1, Box 359, Record 52/546, Archives New Zealand, Wellington (ANZ).

7 James Hislop to George W. Russell, 19 January 1916, 'War Graves - Monthly and General Reports’, ACGO 8333, IA1, Box 1287, Record 7/4/2, ANZ.

${ }^{8}$ Contract of James Cowan of Wellington, 9 March 1918, 'Departmental - Records - Historical - Appointment of Mr. J. Cowan', ACGO 8333, Series IA1, Box 1280, Record 4/2/13, ANZ.

${ }^{9}$ Edith Statham to 'General Robley’, 18 June 1919, 'Robley, H. G. (Major-General)', 1919, Box 10,

FILD0035a, J.C. Beaglehole Room, Victoria University of Wellington (JCBR).

${ }^{10}$ Horatio Gordon Robley to Horace Fildes, 10 March 1919, FILD0035a, JCBR.
} 
the start of Statham's government contract in 1913 and the publication of Cowan's second volume of The New Zealand Wars in 1923. The wider period of their history and memory making activities from roughly 1905, when Cowan and Robley were in correspondence with one another, to 1928, when Cowan and Statham completed their last collaboration on the memorial gateway at Rangiriri Cemetery in 1928, forms the larger arc of the discussion. Through an analysis that draws on their various publications, manuscripts, correspondence and newspaper articles, the discussion charts the formative experiences of the three history-makers, the development of their initiatives as history-makers and memory narrators, and how their histories were sparked by, and in turn shaped, the context around them. The thesis asks: Why did these history-makers turn to narrating the colonial past during this time? What were their own memories of this past that they were drawing from? What were the key themes of their renderings of the colonial past and what did their histories indicate about their perception of contemporary New Zealand and the world in which it existed, and their hopes for a collective New Zealand future?

Edith Mary Statham was born on 13 April 1853, in Liverpool, England. At the age of ten she sailed with her parents and three brothers aboard the Venus to the settlement of Dunedin in the South Island of New Zealand. ${ }^{11}$ Statham's family appeared financially comfortable and Statham and her siblings were well educated. ${ }^{12}$ Edith received training as a singer and later undertook a career in private nursing. ${ }^{13}$ From 1890, Statham set up a business as a typist and, when she was not working, was an active participant in local mobilisations for women's franchise, temperance, ladies' cycling and a variety of other causes for social betterment. ${ }^{14}$ Statham, as an unmarried woman, working for a living and organising politically, typified the 'new woman' ideal at a time when New Zealand was being touted as a leading liberal democracy. Statham's embrace of a progressive citizenship led her to volunteer for the Anglo-South African (Boer) War in 1899. This suggests that for Statham, imperial duty and social progress were not at odds. In 1910, then in Auckland, Statham became involved in the Auckland branch of the newly established Victoria League, an organisation set up in the memory of 'ultimate maternal icon' Queen Victoria, who had died in 1901, with the purpose of strengthening the imperial union amongst women in the respective colonies. ${ }^{15}$ It was here that Statham began the work to refurbish the graves of soldiers who had died fighting for empire in the wars of New Zealand's colonial period, to ensure their legacies be brought into the imperial fold as with the recent Boer War. ${ }^{16}$ In 1913

\footnotetext{
${ }^{11}$ Phillips, To the Memory, p. 35; 'Obituary’, Otago Daily Times (ODT), 15 February 1951, p. 9.

12 Jock Phillips, 'Statham, Edith Mary', Dictionary of New Zealand Biography (DNZB), Encyclopedia of New Zealand (Te Ara), 1996; https://teara.govt.nz/en/biographies/3s32/statham-edith-mary; accessed 15 May 2021; Pamela Wood, Dirt: Filth and Decay in a New World Arcadia, (Auckland: Auckland University Press, 2005), p. 7.

13 'Obituary, ODT, 15 February 1951, p. 9; Evening Star (ES), 3 May 1890, p. 3.

14 'The General Election’, ODT, 20 October 1893, p. 2.

${ }^{15}$ Katie Pickles, 'A link in 'the great chain of Empire friendship': the Victoria League in New Zealand', The Journal of Imperial and Commonwealth History, Vol. 33, No. 1, 2005, p. 29.

${ }^{16}$ Edith Statham to Under Secretary James Hislop, 6 September 1915, ACGO 8333, IA1, 1287, 7/4/2, ANZ.
} 
Statham's work was recognised by Joseph Ward's Government, and she was employed to continue the work under government contract. ${ }^{17}$ Statham maintained her imperialist attitude throughout her work with the government, but the work confronted the racial implications in this imperial agenda that she would have to reconsider in her framework of commemoration. When war casualties grew exponentially from 1915, Statham's work became focused on what came to be the massive enterprise of remembering the dead in distant battlefields. When Statham retired from the public service in 1928, she continued to engage with imperial duty and soldier commemoration through her position as Inspector of Soldier Graves for the Auckland Branch of the Returned Soldiers' Association (RSA). ${ }^{18}$ This was the same branch of the RSA that was active in the establishment of Auckland's War Memorial Museum, lobbying to ensure that the war memorial function took precedence over its other functions as a site. ${ }^{19}$ Statham's pursuit of progressive female citizenship remained shaped by an imperialist agenda throughout her life, whilst she also remained dedicated to ensuring the permanent memory of the local settler colonial story. In this tension she embodies one of the many contradictions of New Zealand's settler colonial society present in this thesis.

Statham's one-time government 'coworker' James Cowan brings rather different considerations to this discussion. Born in Auckland in 1870, at six months old Cowan moved with his family to a military settlement farm just outside the township of Kihikihi, in the Waikato. ${ }^{20}$ The farm lay partially atop the old Ōrākau battle site, where six years earlier Ngāti Maniapoto forces had endeavoured to hold off the invading imperial and colonial forces from the north. ${ }^{21}$ The defensive line had retreated south, beyond the Puniu River, which would eventually mark the border between the independent land of the Kingitanga and the settler farms on the newly confiscated lands. ${ }^{22}$ For much of his working life, Cowan would be defined by this 'borderland' of his youth and it would often serve as the opening credential whenever he engaged with 'Māori subjects' or stories of the frontier. ${ }^{23}$ This was particularly true of his first job as a journalist at the Auckland Star from 1888, where he became known for his reports on 'Māori affairs. ${ }^{24}$ At the turn of the century, Cowan remained focused on Māori, particularly by presenting Māori culture to a non-Māori audience in his travel-marketing work for the

\footnotetext{
17 Ibid.

${ }^{18}$ Edith Statham to Malcolm Fraser, 11 October 1932, 'War Graves - Cemeteries Auckland District - Care of Inspection by Miss E.M. Statham’, ACGO 8333, IA1, Box 1661, Record 32/1/26, Part 2, ANZ.

${ }^{19}$ Scott Worthy, 'Communities of Remembrance: Making Auckland's War Memorial Museum', Journal of Contemporary History, Vol. 39, No. 4, 2004, p. 603.

${ }^{20}$ David Colquhoun, 'Cowan, James', DNZB, Te Ara, 1996, updated 2012; https://teara.govt.nz/en/biographies/3c36/cowan-james; accessed 27 April 2021.

${ }^{21}$ Annabel Cooper, 'Nō Ōrākau: Past and people in James Cowan's places', Journal of New Zealand Studies (JNZS), No. 19, 2015, p. 63.

${ }^{22}$ Kerryn Pollock, 'King Country region - Te Rohe Pōtae', Te Ara; http://www.TeAra.govt.nz/en/king-countryregion/page-6; accessed 28 June 2021.

${ }^{23}$ Ariana Tīkao, 'Borderland: From Archive to Gallery: Working on James Cowan's Papers', JNZS, No. 19, 2015, p. 20.

${ }^{24}$ Chris Hillard, 'Stories of an Era not yet so very remote: James Cowan in and out of New Zealand History', JNZS, No. 19, 2015, p. 30.
} 
Department of Tourist and Health Resorts from 1902. ${ }^{25}$ In this work he became a narrator in the culture of Maoriland, the period in which settler society drew on Māori material to attempt to 'consolidate itself economically and culturally. ${ }^{26}$ Having grown up on a significant battlefield and having honed his 'expertise' on Māori subjects, in 1917 Cowan was the preferred candidate to write a history of the colonial wars in nineteenth-century New Zealand. The $50^{\text {th }}$ anniversaries of the major battles in the Waikato had recently taken place in 1913-14, and with the last of those who had fought in these climactic events coming to the end of their lives, there was a sense that a history needed to be written before it was 'too late. ${ }^{27}$ After the two volumes of his New Zealand Wars was published, Cowan continued to write on Māori subjects, often drawing on the research conducted during his government contract. ${ }^{28} \mathrm{He}$ would continue to publish with his particular formula of drawing on his own nostalgia for the colonial past, until his health precluded further work. ${ }^{29}$ By the 1930 s he was living in Connaught Terrace in Brooklyn, Wellington, with a direct view of the National War Memorial Carillon and Dominion Museum being built on the Mount Cook site below. ${ }^{30}$ Cowan had for most of his career, painted his bordering identity as important to depicting harmonious bicultural relations in his vision of New Zealand's nationhood, but by the later period of his life he was gazing upon a new vision of nationhood, one in which he was increasingly on the margins.

The third history-maker to enter this discussion of nascent 'New Zealand histories', is Horatio Gordon Robley, a former officer in the $68^{\text {th }}$ regiment who fought in New Zealand and had retired to a life as a gentleman collector and author in London. Robley is a complex, and to modern sensibilities, an unpalatable figure. But it is precisely those complexities of time, proximity and distance that makes his ability to contribute to New Zealand histories even more valuable as an addition to the discussion. Unlike his history-making contemporaries, Robley was not born in New Zealand, nor would he settle in the colony. Born in 1840 to a military general father stationed in Madeira, Portugal, Robley was inducted into a military lifestyle from an earlier age as well as developing an interest in art from his mother. ${ }^{31}$ In 1858, Robley joined the $68^{\text {th }}$ regiment of the British Army. In 1864 Robley and the $68^{\text {th }}$ were called to aid the imperial and colonial forces fighting against the uprising of Māori forces in the North Island of New Zealand. ${ }^{32}$ Robley spent all of two years in New Zealand, predominantly in the Bay of Plenty where he fought in the battles of Gate Pa and Te Ranga and spent a significant amount

\footnotetext{
${ }^{25}$ Lydia Wevers, 'Romance of the Rail', JNZS, No. 19, 2015, p. 40.

${ }^{26}$ Jane Stafford and Mark Williams, Maoriland: New Zealand Literature, (Wellington: Victoria University Press, 2006), p. 14.

27 James Cowan to William D.S. Macdonald, 16 November 1917, ACGO 8333, IA1, 1280, 4/2/13, ANZ.

28 'Payments to James Cowan For Writing Official Maori History and Articles for Publications', ACGO 8333, IA1, 1280, 4/2/13, ANZ.

${ }^{29}$ Hilliard, 'Stories of an Era not yet so very remote', p. 34.

${ }^{30}$ Pat Lawlor, Old Wellington Days, (Wellington: Whitcombe \& Tombs, 1959), p. 203.

${ }^{31}$ Horace Fildes, 'Major General H. Gordon Robley: Soldier and Artist', 1921, Fildes MSS 1507, Folder 1, JCBR, p. 4.

32 Horatio Gordon Robley, ‘Army Service from 1858', c. 1919, Notebook containing autobiographical notes by Maj.-Gen. H. Robley, Box 22, FILD00056, JCBR, p. 6.
} 
of time with local Māori, sketching and painting many of the scenes he had witnessed. ${ }^{33}$ The regiment was called away again in 1866. Despite this short length of time actually in New Zealand, the engagements would come to define both his work and his character upon his final return to Britain and through his retirement from the military in 1887. Residing in London, Robley began collecting Māori artefacts that had made their way into the European market through dubious nineteenth-century trading networks, including the collection of preserved Māori heads he has come to be most well-known for. ${ }^{34}$ Through this collection, and his 1896 publication on Moko; or Maori Tattooing, Robley was brought into discourses of Maoriland from London. Robley would get another opportunity to bolster his status as a 'New Zealander' when he caught wind of a history of the wars that had brought him to New Zealand in 1864 being funded by the New Zealand government in $1918 .{ }^{35}$ Caught in the excitement of this new focus on the colonial past, Robley engaged in a flurry of correspondence with those back in New Zealand. One of his key confidants was bibliographer Horace Fildes. In 1919, Fildes travelled to London, collecting notes, ephemera and some of Robley's reproduced watercolours. ${ }^{36}$ Robley, an elderly man by this time, remained in correspondence with those in New Zealand for another decade until his death at 90 years of age in 1930. Robley was gone by the time Lord Bledisloe lit the 'lamp of remembrance' at the National War Memorial in 1932, but once the Museum and Gallery building was in place it was Robley whose work would be part of this new national vision. In the Dominion Museum collections were 70 of Robley's sketches and watercolours, including those that Fildes donated in 1937, a year after the completion of the building. ${ }^{37}$ Robley had fought in the colonial wars as a young officer, in his retirement many decades later, he became active in shaping the memory and the history of those events in a very different political and cultural context. His appearance in the national museum stands as testament to his contributions to the creation of 'New Zealand', in London.

Cowan has undoubtedly received the most historiographical attention, with his historical legacy having been widely debated in the last forty years. When a revised edition of The New Zealand Wars was published in 1983, historian Michael King lent his voice to the introduction. ${ }^{38}$ King positioned himself as proponent of Cowan's nostalgic style of history, citing Cowan in his own story of nativism as a child growing up in Paremata near the locations of significant historical engagements between Māori and Pākehā. ${ }^{39}$ In some ways, King himself appeared as an echo of Cowan's work to foster a cultural locality in New Zealand, when he went on to publish his autobiographies, Being Pakeha (1985)

\footnotetext{
33 Ibid.

${ }^{34}$ Horatio Gordon Robley, 'Chapter on Maori Art Collecting and Book Thereon', c. 1919, Autobiographical notes by Maj.-Gen. H. Robley, FILD00057, JCBR, pp. 10-11.

${ }^{35}$ Horatio Gordon Robley to Horace Fildes, 10 March 1919, FILD0035a, JCBR.

${ }^{36}$ See acquisition information of Major General Horatio Robley, 'No 3 Gate Maketu Pa', 1865, Reg. no. 1992-

0035-1892, Te Papa Collections; https://collections.tepapa.govt.nz/object/98620; accessed 16 April 2021.

${ }^{37}$ Ibid.

${ }^{38}$ Michael King, 'Introduction', in James Cowan, The New Zealand Wars: A History of the Maori Campaigns and the Pioneering Period, Vol. I, $3^{\text {rd }}$ ed. (Wellington: Govt Printer, 1983), p. v.

${ }^{39}$ Ibid; Lydia Wevers has explored Michael King's story of nativism in his historical work in 'Being Pakeha:

The Politics of Location', JNZS, No. 4, October 2005, pp. 1-9.
} 
and Being Pakeha Now (1999) proposing on the front cover of the latter that Pākehā who were committed to 'this land and its people' were no less 'indigenous than Maori. ${ }^{40}$ King went on to praise Cowan's early oral history research methodology as well as delineating Cowan's mannerisms and ideas about Māori in the publication that were 'limiting', suggesting that Cowan often 'sentimentalised earlier Māori life to the point of unreality. ${ }^{41}$ In doing so, King went a step further in critique of Cowan than James Belich would in his 1986 work, The New Zealand Wars and the Victorian Interpretation of Racial Conflict. ${ }^{42}$ Belich's main line of argument in considering Cowan's legacy within the historical field was that Cowan's work had 'an obvious bias and obvious weaknesses, but to castigate him for being a man of his era is a fruitless exercise. ${ }^{43}$ To do so, Belich argues, would be to miss the intensity of the anglocentric mood of his context, in which he demonstrated 'impressive' balance. ${ }^{44}$

More recently, David Colquhoun has written the entry on Cowan for the Dictionary of New Zealand Biography. ${ }^{45}$ When Colquhoun does make a stated position on parts of Cowan's work, it is largely in line with other more contemporary analyses of Cowan such as Chris Hilliard's 1997 thesis chapter on Cowan. ${ }^{46}$ Neither of the considerations of these historians has been for Cowan as a 'man of his time', nor do they shy away from critiquing his romantic portrayals of colonial conflicts. ${ }^{47}$ Both have included discussions of Cowan's interactions with more modern scholars, particularly looking at the original draft of his 1940 Settlers and Pioneers as an example of Cowan's more articulate opposition to land confiscation. ${ }^{48}$ In doing so, Hilliard in particular, acknowledges the myth-making aspects of most of Cowan's work, but appears to lean towards a more favourable characterisation of Cowan particularly because of his opposition to the more repressive style of public history that had eclipsed his own. ${ }^{49}$ This sympathetic analysis appears to be the predominant interpretation of the 2015 special volume of the Journal of New Zealand Studies on James Cowan, with contributors including Hilliard, Annabel Cooper, Paul Meredith, Michael Belgrave, Vincent O’Malley. ${ }^{50}$ O’Malley would go on to republish his article as a chapter in The Great War for New Zealand: Waikato 1800-2000. ${ }^{51}$ Following in Cowan's war history footsteps, O’Malley had to consider Cowan (and Belich’s) approach to the New

\footnotetext{
${ }^{40}$ Michael King, Being Pakeha Now, (Auckland: Penguin Books, 1999).

${ }^{41}$ King, 'Introduction', p. viii.

42 James Belich, The New Zealand Wars and the Victorian Interpretation of Racial Conflict, (Auckland:

Auckland University Press, 1986).

43 Ibid, p. 16.

${ }^{44}$ Ibid.

${ }^{45}$ Colquhoun, 'Cowan, James', DNZB.

${ }^{46}$ Chris Hilliard, 'Island Stories: The Writing of New Zealand History', MA thesis, Auckland University, 1997; Chris Hilliard, The Bookmen's Dominion: Cultural Life in New Zealand, 1920-1950, (Auckland: Auckland University Press, 2006), continues to demonstrate a similar, slightly more sympathetic view of Cowan.

${ }^{47}$ Ibid, p. 43.

${ }^{48}$ Ibid, pp. 48-51.

${ }^{49}$ Ibid, pp. 48-51.

50 'James Cowan and the Legacies of Late Colonial Culture in Aotearoa New Zealand', JNZS, No. 19, 2015.

${ }^{51}$ Vincent O’Malley, The Great War for New Zealand: Waikato 1800-2000, (Wellington: Bridget Williams Books, 2016).
} 
Zealand Wars, in which he credits Cowan's more 'meaningful analysis' than Belich's for his own approach. ${ }^{52}$ O'Malley's publication is also significant to the focus on colonial memory in this thesis and will be revisited shortly. This thesis, focused specifically on Cowan's contributions to public remembering in the early twentieth-century context, is primarily concerned with his legacy within New Zealand memory.

In her contribution to the 2015 James Cowan collection, Lydia Wevers focuses on Cowan's travel writing, specifically looking at his 1928 brochure entitled Romance of the Rail. ${ }^{53}$ Within this specific example, Wevers has been able to tease out some of the deeper contradictions in Cowan's work, particularly in regards to his ambivalent attitude towards Māori within New Zealand society of the present and the future. Her textual analysis is effective in demonstrating Cowan's inability to divorce his positive view of Māori from his nostalgia for his childhood. ${ }^{54}$ Wevers' analysis has been particularly formative in this thesis for how her arguments of the persistent nature of Cowan's nostalgia might be visible in his work outside the travel writing realm.

The historiography on Robley and Statham has been comparatively scant. The foremost analysis of Robley's work has been Timothy Walker's 1985 art history thesis that analyses the historical context of Robley's collection of mokomokai but predominantly focuses on Robley's examination of the moko practice. ${ }^{55}$ Also within an art history realm, Leonard Bell has looked at Robley's watercolour and sketch representations of Māori as part of a broader study of Māori within European art in the late nineteenth century. ${ }^{56}$ Statham is yet to receive a full historical study, however her work has been brought to light by Jock Phillips, who first included a study of her soldier grave and memorial work in his study of New Zealand war memorials in $1990 .{ }^{57}$ Katie Pickles has also drawn Statham into an analysis of the Victoria League's imperial work in New Zealand. ${ }^{58}$

There have been some significant bodies of work that have brought the history-makers together into analyses of the different contexts traversed in this thesis. Roger Blackley's influential work looking at the collector, artist and exhibiting networks of Maoriland in 1880-1910, draws both Cowan and Robley into his analysis, though never in direct comparison or connection..$^{59}$ Kynan Gentry has drawn Cowan and Statham together in an analysis of history, myth and forgetting of the New Zealand Wars in

\footnotetext{
52 Ibid, pp. 12-13.

53 Wevers, 'Romance of the Rail'.

${ }^{54}$ Ibid, pp. 45-46.

55 Timothy Walker, ‘Robley: Te Ropere 1840-1930’, MA thesis, Auckland University, 1985.

${ }^{56}$ Leonard Bell, Colonial Constructs: European Images of Maori, 1840-1914, (Auckland: Auckland University Press, 1992), pp. 99-124.

57 Jock Phillips and Chris Maclean, The Sorrow and the Pride, (Wellington: Department of Internal Affairs, 1990), p. 31.

${ }^{58}$ Pickles, 'The Victoria League in New Zealand', p. 36.

${ }^{59}$ Roger Blackley, Galleries of Maoriland: Artists, Collectors and the Māori World, (Auckland: Auckland University Press, 2016), pp. 209, 237.
} 
his 2015 publication on historical consciousness and cultural identity in New Zealand 1870-1940. ${ }^{60}$ The opening chapter to Vincent O’Malley's work The Great War for New Zealand has offered part of the latest studies of the history-makers in the context of the remembering and forgetting of colonial conflict. ${ }^{61}$ As part of a broader long history of the 1863-1864 conflict in the Waikato, O’Malley draws on both Cowan's and Statham's work to look at the long term trends of the Waikato War in collective New Zealand memory, up to the present day. ${ }^{62}$

In demonstrating the salience of this converging moment in Cowan and Statham's memorymaking, O’Malley's work has undoubtedly been influential in the development of this thesis. However, in bringing a third history-maker in Robley, I hope to add an additional layer of analysis concerning who is making these colonial New Zealand histories and what that might say about where and with whom New Zealand memory was created. To this end, Charlotte Macdonald's 2015 article on 'The First World War and the Making of Colonial Memory' has also been a key source of inspiration. ${ }^{63}$ In her discussion, Macdonald considers all three-history-makers to draw conclusions about how the memory of the colonial period contrasted with remembrance of the recent war dead of the First World War. ${ }^{64}$ This thesis draws on Macdonald and O'Malley's juxtaposition with the memory of the First World War period, which also serves as a particular point of convergence between the three historymakers. Both Macdonald and O'Malley have broached the issue of the fluctuating remembering and forgetting of the New Zealand Wars outside of this point of convergence, using contemporary examples of Pākehā forgetting in their analyses. ${ }^{65}$ This thesis teases out some of the reasoning behind these fluctuations by providing some of the key cultural processes that accelerated from 1901, leading to the powerful and perplexing convergence of Cowan, Statham and Robley’s history-making between c. 1914 and 1923. In considering the history-makers' attempt to continue their historical work after 1923 and in the lead up to the 1940 centenary celebrations, the discussion demonstrates the ephemeral nature of historical memory within the logic of settler colonialism in New Zealand. In doing so, this thesis broadens the scholarship on Robley and Statham and situates Cowan's much-analysed work into a fuller cultural analysis of the different ideas of belonging in New Zealand, in the period c. 1901-1940.

This thesis is an analysis of Cowan, Statham and Robley's historical memory as a part of the deep contradictions at the heart of settler colonialism and draws on a series of settler colonial studies to situate their work within settler colonial processes. Patrick Wolfe's influential essay that argues for settler colonialism as a structure rather than an event, has been foundational to situating Cowan, Statham and Robley's intensive attempts to remember colonial conflict within a broader settler colonial process

\footnotetext{
${ }^{60}$ Kynan Gentry, History, Heritage, and Colonialism, (Manchester: Manchester University Press, 2015).

${ }^{61}$ O’Malley, The Great War for New Zealand: Waikato 1800-2000, pp. 15-31.

62 Ibid, pp. 17-28.

${ }^{63}$ Charlotte Macdonald, 'The First World War and the Making of Colonial Memory', Journal of New Zealand Literature, Vol. 33, No. 2, 2015.

${ }^{64}$ Ibid, p. 16-17.

65 Ibid, p. 15; O’Malley, The Great War for New Zealand: Waikato 1800-2000, pp. 15-17.
} 
that Wolfe reminds us is defined by its modernist forward momentum. ${ }^{66}$ Wolfe's other frequently drawn on idea is of elimination as the 'logic of settler colonialism', in which settler society expropriates territory, alienates, assimilates, converts indigenous peoples as part of the 'organising principles' of forming a new colonial society. ${ }^{67}$ J. Kēhaulani Kauanui’s revision of Wolfe’s 2008 essay, emphasising the endurance of indigeneity within this settler-colonial structure, has also been considered in the relationships traversed in this thesis. ${ }^{68}$ Nevertheless, Wolfe's work, along with that of Lorenzo Veracini, has been crucial for elucidating the irreversibly transformative aspects of settler colonial logic and its inextricable link to the principles of modernity. ${ }^{69}$ On this last point, Marilyn Lake's 2019 Progressive New World: How Settler Colonialism and Transpacific Exchange Shaped American Reform has been formative to understanding the contradictory relationships and ideas traversed in this thesis. ${ }^{70}$ In Progressive New World, Lake explores a similar turn of the century timeframe as this thesis, pointing to the significant convergence of racial sensibilities and the forging of an ideal social order by political reformers in Australasia and America. Though the task of the history-makers has been more to remember rather than politically reform, Lake’s paradoxical illustration has informed the awareness of these contradictions without trying to resolve their contrasting approaches to remembrance.

As broached by Macdonald and O’Malley, one key characteristic of postcolonial settlercolonial society is its habit of forgetting. Yet the three people at the heart dedicated a considerable effort to remembering and narrating the colonial past, when the 'logic' of settler colonialism was challenged by those peoples attempting to be displaced. This thesis explores this disrupting phenomenon and whether history-making and settler forgetting can be simultaneous. Paul Connerton's 'Seven types of forgetting' of the modern nation-state has been useful here. In considering the settler-colonial polity, this thesis looks specifically at Connerton's theory of 'the forgetting that is constitutive to the formation of a new identity. ${ }^{71}$ In his argument Connerton explains that this type of forgetting is not often seen as a loss but rather a discarding of memories that do not serve the 'management' of one's 'current identity and ongoing purposes. ${ }^{72}$ In his argument Connerton highlights the key focus of this thesis, that 'no narrative of modernity as a historical project can afford to ignore its subtext of forgetting. ${ }^{73}$

As Connerton acknowledges, there is a particular relationship between history and forgetting. There is a significant body of work exploring this dichotomy in settler societies. Wolfe and Veracini

\footnotetext{
${ }^{66}$ Patrick Wolfe, 'Settler Colonialism and the Elimination of the Native', Journal of Genocide Research, Vol. 8, No. 4, 2006, p. 388.

${ }^{67}$ Ibid, p. 387.

${ }^{68}$ J. Kēhaulani Kauanui, ““A Structure, Not an Event”: Settler Colonialism and Enduring Indigeneity’, Emergent Critical Analytics for Alternative Humanities, Iss. 5, No. 1, 2016.

${ }^{69}$ Lorenzo Veracini, The Settler Colonial Present, (London: Palgrave Mcmillan, 2015), p. 49.

${ }^{70}$ Marilyn Lake, Progressive New World: How Settler Colonialism and Transpacific Exchanged Shaped American Reform, (London: Harvard University Press, 2019).

${ }^{71}$ Paul Connerton, The Spirit of Mourning: History, Memory and the Body, (Cambridge: Cambridge University Press, 2011), p. 36.

${ }^{72}$ Ibid, p. 37.

${ }^{73}$ Ibid, p. 38.
} 
have both incorporated the relationship between history and settler colonial forgetting in their respective bodies of work. According to Wolfe, the selective amnesia in histories of the settler state operate as a fantasy of settler colonial logic, whereby indigenous peoples are removed from the stories of settler and landscape, in what he terms a 'solipsistic narrative. ${ }^{, 74}$ Veracini has built upon this point by addressing the 'victimologies' of settler histories, whereby the struggle with the land is emphasised to legitimise the settler claims to country, over indigenous and later migrant relationships with the land. ${ }^{75}$ There have been plenty of New Zealand contributions to this historical forgetfulness. Stephen Turner's 1999 essay 'Settlement as Forgetting' has demonstrated how history has the potential to be the deepest form of forgetting, by romanticising the colonial past to the point of denial of contact. ${ }^{76}$ The 'dream' of settler history, Turner argues, is that the present is better than the past, the new country better than the old, which presents particular issues for how to categorise Māori defiance. ${ }^{77}$ Charlotte Macdonald's 2019 study of New Zealand's historical forgetfulness through an exploration of New Zealand as a garrison colony rather than a settler colony, has been a powerful contemporary disruption of New Zealand's 'dream' or 'fantasy' of its settling past. ${ }^{78}$ This change in terminology, Macdonald argues, reminds contemporary New Zealand of the truly coercive nature of British military presence in the colonial period and demands recognition of New Zealand's history of settler colonialism and imperial governance. ${ }^{79}$ Turner and Macdonald are just two examples of an ongoing interrogation of history's active role in the forgetfulness of postcolonial settler societies like New Zealand. There has of course been an extensive body of work that offers new approaches in addressing New Zealand's relationship with its past that is working to decentre Pākehā from the theoretical framework of New Zealand history. ${ }^{80}$ This wealth of scholarship problematising New Zealand's historical forgetting has been crucial to understanding Cowan, Statham and Robley's early twentieth-century histories as part of a larger, settler colonial process.

In analysing the type of colonial memory that the three history-makers were fostering, this thesis has drawn on several memory studies. As the selective amnesia of settler societies suggests, the

\footnotetext{
${ }^{74}$ Patrick Wolfe, ‘Islam, Europe and Indian Nationalism: Towards a Postcolonial Transnationalism', in Ann Curthoys and Marilyn Lake (eds), Connected Worlds: History in Transnational Perspective, (Canberra: ANU EPress, 2005), p. 235.

${ }^{75}$ Lorenzo Veracini, 'Historylessness: Australia as a Settler Colonial Collective', Postcolonial Studies, Vol. 10, no. 2, 2007, p. 274.

${ }^{76}$ Stephen Turner, 'Settlement as Forgetting', in Klaus Neumann, Nicholas Thomas and Hilary Ericksen (eds.), Quicksands: Foundational histories in Australia and Aotearoa New Zealand, (Sydney: University of New South Wales Press, 1999).

${ }^{77}$ Ibid, p. 35.

${ }^{78}$ Charlotte Macdonald, 'Woolwich to Wellington: From Settler Colony to Garrisoned Sovereignty', New Zealand Journal of History (NZJH), Vol. 53, No. 1, 2019.

${ }^{79}$ Ibid, p. 66.

${ }^{80}$ See examples: Linda Tuhiwai-Smith, Decolonising Methodologies: Research and Indigenous Peoples, (Dunedin: Otago University Press, 1999); Nēpia Mahuika, “Closing the Gaps': From Postcolonialism to Kaupapa Maori and Beyond', NZJH, Vol. 46, No.1, 2011; Te Maire Tau, 'I-nga-ra-o-mua', JNZS, Vol. 10, 2011.
} 
way the past is remembered holds particular importance for cultivating a sense of a collective identity and many of the memory studies included in this discussion address the relationship between collective memory and the nation. A crucial contextual concern for Cowan, Statham and Robley's histories is that they occur within the same period as the 'memory boom' of Great War remembrance, which hold particular relevance to Statham's medium of the public memorial site. ${ }^{81}$ The concept of the memorial site as a phenomenon of the modern twentieth-century nation is a central feature of Pierre Nora's 198492 seven-volume study of les lieux de mémoire or sites of memory. ${ }^{82}$ In the New Zealand context, Jock Phillips' extensive research into New Zealand war memorials and Kathryn Hunter's 'glimpse' into Invercargill's mourning community have been amongst a body of work which has been formative in understanding the memorial site and its rituals of public bereavement. ${ }^{83}$ In Phillips' study he makes the key assertion that the history of the war memorial in New Zealand can only be understood within a British imperial context, a point on 'belonging' in New Zealand that forms an essential arc of this thesis and will be returned to shortly. ${ }^{84}$ Nora's concept of the site of memory as ‘between' memory and history is applicable across the work of all three history-makers. In a 1989 article, Nora focuses more generally on the 'symbiotic' relationship between memory, history and the nation, which has been key to understanding the collective consolidation occurring in Cowan, Statham and Robley's histories in their early twentieth-century context. ${ }^{85}$ In understanding how the history-makers framed the colonial conflicts within this memory boom context, Benedict Anderson's Imagined Communities has been useful, particularly in his articulations of the national mythologies that are created around antecedent internal conflicts. ${ }^{86}$ According to Anderson, civil wars are often used as a demonstration of brotherly antagonisms and give a sense of tested strength in national brotherhood of the present day. ${ }^{87}$ Many of these memory studies concern how Great War memory shaped the modern nation: While this overlaps with the topical concerns of this thesis, it is an idea in which a full analysis lies outside the scope of this discussion.

In the process of weaving together the work of remembering of the three history-makers, some further memory theories have been useful. Raphael Samuel's visual of the 'theatre of memory' has been useful to this conceptualisation of Cowan, Statham and Robley’s respective historical mediums: Cowan

\footnotetext{
${ }^{81}$ See Jay Winter, Remembering War: The Great War Between Memory and History in the twentieth century, (New Haven: Yale University Press, 2006).

${ }^{82}$ Pierre Nora, Rethinking France: Les Lieux de Memoire, Revised Edition (Chicago: Chicago Press, 2001).

${ }^{83}$ Phillips, To the Memory; Kathryn Hunter, “'Sleep. on dear Ernie, your battles are o’er’: A Glimpse of a Mourning Community, Invercargill, New Zealand, 1914-1925’, War in History, Vol. 14, No, 1, 2007.

${ }^{84}$ Phillips, To the Memory, p. 17.

${ }^{85}$ Pierre Nora, 'Between Memory and History: Les Lieux de Mémoire’, Representations, No. 26, Spring 1989, p. 10.

${ }^{86}$ Benedict Anderson, Imagined Communities, Revised Edition (London: Verso, 2006), pp. 201-202.

${ }^{87}$ Ibid.
} 
and print media, Statham and public space, and Robley's contributions to the 'theatre' of the museum. ${ }^{88}$ Samuel's visual of the theatre, gives a sense of the network of correspondence between the three historymakers in their respective theatres, as casting a nexus of memory across their shared 'audiences.' Anderson has formed a similar argument in his theory of the interlinked relationship between the census, the map and the museum as a 'totalising classificatory grid' of the 'late colonial state's thinking about its domain. ${ }^{89}$ What these memory-focused studies suggest is that while Cowan, Statham and Robley’s history-making occurred within a forgetful settler-colonial context, their localising narratives did have impact within the brief era in which their memory-making converged.

Notions of belonging form a key strand of discussion in the thesis. While I have situated the work of the three history-makers within the logic of settler colonialism, in this next section I will delineate the different considerations of cultural belonging in the c.1901-1940 period. In this period there were significant attempts to create a sense of a cultural locale in New Zealand, but simultaneously it was a period in which New Zealand society sought to affirm its imperial citizenship. James Belich has recognised this in Paradise Reforged, identifying both a culture of national and imperial identification amongst New Zealand's settling population during the period from 1880 to the 1920 s that he terms as 'the great tightening' of social, moral and racial integration. ${ }^{90}$ Historian Kathryn Hunter has vividly described this coexistence as the 'tangled knot' of belonging, in her work looking at national and imperial belonging during the First World War. ${ }^{91}$ The image of a 'tangled knot' is particularly salient to this discussion of the activities of three different individuals, each coming to a sense of belonging in their own way, yet in paths that crossed and converged.

Broader discussions of both the sense of belonging to a cultural locale and belonging to the wider empire are explored through the work of Cowan, Statham and Robley. Chapters One and Two explore Cowan and Robley's participation in the early generation of cultural nationalism present in the discourses around Maoriland. To contextualise their contributions to this realm this thesis draws on Jane Stafford and Mark Williams’ Maoriland research into New Zealand literature in 1872-1914 and Blackley's Galleries of Maoriland. ${ }^{92}$ The discussion of Cowan and Robley's work throughout the thesis will also incorporate historian Peter Gibbons’ influential idea of the ‘cultural colonisation’ referring to the 'plunder' of Māori culture and accepted displacement of Māori in early articulations of New Zealand as a nation. ${ }^{93}$ In order to encapsulate the imperial fervour in the wake of the Anglo-South African War

\footnotetext{
${ }^{88}$ Macdonald has also drawn on this 'theatres of memory' idea in 'The First World War and the Making of Colonial Memory’; Raphael Samuel, Theatres of Memory, Volume I: The Past and Present in Contemporary Culture, (London: Verso, 1994).

${ }^{89}$ Anderson, pp. 163-164.

90 James Belich, Paradise Reforged, (London: Penguin Books, 2002), p. 121.

${ }^{91}$ Kathryn Hunter, 'National and Imperial Belonging in Wartime: The Tangled Knot of Australians and New Zelanders as British Subjects during the Great War', Australian Journal of Politics and History, Vol. 63, No. 1, 2017, p. 32.

92 Stafford and Williams; Blackley, Galleries of Maoriland.

93 Peter Gibbons, 'Cultural Colonisation and National Identity’, NZJH, Vol. 36, No. 1, 2002, pp. 5-17.
} 
and Queen Victoria’s death, Katie Pickles' multiple studies into the rise of female imperialism across the empire out of this catalytic turn-of-the-century moment have been formative. ${ }^{94}$ Because of this, Pickles' work has been key to situating Statham and her more imperial-driven work within the same time period as Cowan and Robley's cultural nationalism. Steven Loveridge's thesis which looks at the cultural mobilisation in New Zealand in the lead up to the Great War and the concept of New Zealand as a distinctive part of 'a global British order' has also been key to understanding the strength of the imperial sentiment in New Zealand in that 1901-1914 time frame. ${ }^{95}$ While Robley was more like Cowan in his engagement in the discourses of Maoriland, his London location has added some important considerations for the intimate relationship between New Zealand and the imperial metropole. Felicity Barnes' exploration of the 'New Zealand's London', or as she terms it the 'appropriation' of London by visiting New Zealanders, has been crucial for understanding both the imperial sentiment of many of these travellers back to the metropole and also how Robley was able to engage with New Zealanders from London. ${ }^{96}$

This thesis traverses the distinctly martial nature of early New Zealand history, with the New Zealand Wars, the Anglo-South African War and the Great War each defining the focus of Cowan, Statham and Robley's constructions of the past. Macdonald recognises this in her work looking at New Zealand as a garrison colony, emphasising the centrality of war to 'political, constitutional, fiscal, social and cultural change within societies and polities. ${ }^{97}$ This emphasis on martial engagements holds important considerations for the gendered aspects of the history-makers' work, and also how those intersect with racial sensibilities. Steven Loveridge's work examining the underlying themes of masculinity in the portrayals of modernity in New Zealand leading up to the Great War has been formative to understanding the inseparability of masculine ideals and progressivism in New Zealand. ${ }^{98}$ Loveridge, along with Franchesca Walker, have both demonstrated how the Māori martial race myth was incorporated into ideas of New Zealand as a modern, martially superior nation serving the empire at war. ${ }^{99}$ To understand how the history-makers contributed to this sense of a bicultural martial identity, this thesis has drawn upon the work of Brendan Hokowhitu, who has demonstrated how myth-making about Māori and war has created false interpretations of Māori masculinity. In his 2008 work addressing the false assertion that Māori society was traditionally patriarchal, Hokowhitu outlined the perception

\footnotetext{
${ }^{94}$ Pickles, 'The Victoria League in New Zealand'; Katie Pickles, Female Imperialism and National Identity, (Manchester: Manchester University Press, 2002).

${ }^{95}$ Steven Loveridge, 'Sentimental Equipment: New Zealand, the Great War and Cultural Mobilisation', Doctor of Philosophy in History, Victoria University of Wellington, 2013, p. 30.

${ }^{96}$ Felicity Barnes, New Zealand's London: A Colony and its Metropolis, (Auckland: Auckland University Press, 2012), p. 46.

${ }^{97}$ Macdonald, 'Woolwich to Wellington, p. 66.

${ }^{98}$ Steven Loveridge, ' 'Soldiers and Shirkers’ Modernity and New Zealand Masculinity During the Great War', NZJH, Vol. 47, No. 1, 2013.

99 Ibid, p. 66; Franchesca Walker, “"Descendants of a Warrior Race”: The Maori Contingent, New Zealand Battalion, and Martial Race Myth’, War \& Society, Vol, 31, No. 1, 2012, p. 5.
} 
of Māori 'evolution' as a transformation from 'violent savage to noble savage, to hued citizen. ${ }^{\text {'00 I }}$ have previously incorporated this model into a textual analysis of Cowan's rendering of Māori figures in his historical writing to demonstrate that Cowan's favoured 'type' of Māori was the 'noble savage' of a recent past, those who demonstrated a 'traditional' patriarchal behaviour but not the full 'reversion' to Hokowhitu's notion of the 'violent savage.' ${ }^{101}$ While the focus of this thesis takes another direction, this type of 'selection' of preferred Māori men is apparent in all three of the history-makers' work, demonstrating Hokowhitu's argument that Māori masculinity has been both 'imbibed with privilege and denied it. ${ }^{102}$ This holds particular pertinence for Cowan and Robley's romantic histories that focus on 'heroic' forms of masculinity, Māori in their 'traditional' patriarchal form and adventurous Pākehā pioneers and protagonists.

This martial context holds a particular set of concerns for Statham as a woman who threw her life's work into affirming the importance of the male soldier-citizen through war memorials and commemoration. Understanding how Statham fits into these ideas of masculine modernity requires a look at the formulation of her sense of progressive female citizenship while she was in Dunedin between 1863 and 1900. Before Statham was volunteering as a frontline nurse in the Anglo-South African War or memorialising those who fought for empire in New Zealand, she was actively involved in franchise, temperance, and other progressive Dunedin organisations. In this context, Barbara Brookes, Annabel Cooper, and Robin Law's edited volume Sites of Gender, which explores the gendered nature of modernity in Southern Dunedin 1890-1939 has been an important source. ${ }^{103}$ Statham's Dunedin background is therefore crucial to understanding her sense of imperial duty as an extension of progressive citizenship. If the modern, martial, democratic soldier-citizen is forged through war, then Statham's foray into martial memory-making appears as an attempt to create the same social and political emancipation for herself. Statham is deeply dichotomous in this respect, embodying the contradictory nature of progressive, settler societies like New Zealand, as has been argued by Marilyn Lake. Lake's chapter on 'Woman Suffrage as an Object Lesson', has informed this discussion of Statham's progressive female agency within the realm of heroic, masculine and martial histories. ${ }^{104}$ The argument also draws connections with the discourse around the status of white women in the 'progressive new world' and the status of indigenous peoples. ${ }^{105}$

\footnotetext{
${ }^{100}$ Brendan Hokowhitu, ‘The Death of Koro Paka: “Traditional” Māori Patriarchy', The Contemporary Pacific, Vol. 20, No. 1, 2008, p. 118.

${ }^{101}$ Lydia Whiting, 'Memories of the Masculine: James Cowan and the Homogenising of a New Zealand Collective Memory', BA(Hons) Research Essay, Victoria University of Wellington, 2019, p. 11.

${ }^{102}$ Brendan Hokowhitu, 'Producing Elite Indigenous Masculinities', Settler Colonial Studies, Vol. 2, No. 2, 2012, p. 29.

${ }^{103}$ Barbara Brookes, Annabel Cooper and Robin Law (eds.), Sites of Gender: Women, Men and Modernity in Southern Dunedin, 1890-1939, (Auckland: Auckland University Press, 2003).

${ }^{104}$ Lake, p. 150.

105 Ibid.
} 
All three of these history-makers occupy ambivalent positions from a contemporary standpoint. As is evident in the historiography, Cowan's work has received plenty of debate about how to conceptualise his contributions to the field of history or to wider considerations for Māori and Pākehā relations. The general consensus in the historical field is that Cowan's published works had some significant flaws in their romanticisation of colonial relations between Māori and Pākehā. ${ }^{106}$ But that Cowan’s research collecting accounts from both Māori and Pākehā informants demonstrated a personal research methodology that was ahead of its time. ${ }^{107}$ Without disregarding this multifaceted nature of Cowan's legacy, this thesis addresses how his work contributes to the wider discourse of memory that was present as he wrote his histories and how it was part of a wider set of activities.

Statham's memorialising work has pertinence in relation to the recent international discussions around statues and other public sites of memory as colonial legacies. In recent years this debate has reached epochal levels, particularly in the American South. ${ }^{108}$ More locally, the debate has thrown New Zealand's many statues and places named after problematic historical figures such as Captain James Cook into sharp relief. ${ }^{109}$ Statham was closely tied to the construction of one of New Zealand's most divisive monuments: the New Zealand War Memorial on the corner of Symonds and Wakefield Street in Auckland's central city. The memorial has been the subject of protest and defacement for many years. ${ }^{110}$ As this thesis delineates, Statham's logic in deciding what and who were to be memorialised is decidedly more complex than many of these examples can illustrate. But they do, however, offer important considerations about the historical medium of the memorial site and the long-term impact of Statham's contributions to colonial memory and nascent history-making.

Robley, who has predominantly come to be known to a contemporary audience through his collection of mokomokai, has possibly the most enduringly difficult legacy of the three history-makers. A particularly confronting image of him with his full collection is often the first result if one was to search Robley on the internet. To this part of Robley's legacy there is much room for critique, particularly given the repatriation of his collection in 2014 to New Zealand's national museum, Te Papa Tongarewa and the recent debate surrounding the ethical procedures for museums holding kōiwhe

\footnotetext{
106 See Wevers, 'Romance of the Rail'.

${ }^{107}$ See Paul Meredith, 'Tēnā koe Hēmi Kāwana: A Ngāti Maniapoto Half-Caste from Kihikihi Greets James Cowan', JNZS, Vol. 19, 2015.

${ }^{108}$ A notable example has been the Robert E. Lee statue, recently removed in Charlottesville, North Carolina; Maya Yang and Oliver Milman, 'Charlottesville removes Confederate statues that helped spark deadly rallies', The Guardian, 10 July 2021; https://www.theguardian.com/us-news/2021/jul/10/charlottesville-statue-; accessed 13 July 2021.

109 “'Stop immortalising a legacy of murder”: Which NZ statues need to be toppled?’, The Spinoff; 12 June 2020; https://thespinoff.co.nz/atea/12-06-2020/stop-immortalising-a-legacy-of-murder-which-nz-statues-needto-be-toppled/; accessed 13 July 2021.

${ }^{110}$ Phillips, To the Memory, p. 52.
} 
tangata. ${ }^{111}$ Such a full inquiry lies outside the scope of this thesis, though their importance is fully acknowledged. Robley's inclusion into a discussion of New Zealand memory and nascent histories is however, important in addressing his early twentieth-century engagement in 'New Zealand' conversations from London. Rather than a stand-alone figure outside of a New Zealand discourse, Robley was an active participant in creating New Zealand's colonial memory and is just as much a creator of New Zealand's cultural history as Cowan and Statham.

The first chapter considers the colonial period in New Zealand as Cowan, Statham and Robley experienced it. Structured by their separate experiences, the chapter chronicles the moment of their respective 'arrivals' in New Zealand through to their work towards the end of the nineteenth century. First to arrive was Statham in 1863, whose experiences in Dunedin as a well-off single woman, were marked by her engagement in early feminist movements within the politically and socially minded climate of the Southern city. Robley followed shortly after, arriving in Auckland in 1864 as officer in the $68^{\text {th }}$ regiment of the British army. His time in New Zealand was short but influential to the remainder of his work within the period. Cowan finally 'arrived' in 1870, as an infant to another embattled context, the newly established military settlements of the Waikato, where he would experience his formative years in the shadow of the deadly conflicts between Māori and Pākehā. These separate experiences, dictated by both their own and secondhand records of the time, are crucial to understanding the individual experience at the heart of those they would eventually dictate for the collective.

The second chapter charts the new formative era in the history-makers' work in the early years of the twentieth-century until the outbreak of the First World War in 1914. Taking into consideration the technological and political developments in national and international communications, this chapter observes the way in which the three history-makers represent the 'entangled' national and imperial sentiments in New Zealand at the time. It begins with Robley's attempts to have his collection of mokomokai incorporated in a national New Zealand museum collection. The discussion then turns to Cowan's work to market New Zealand as a destination in his work at the Department of Tourist and Health Resorts. The chapter then charts the growth of imperial ideologies following the end of the Anglo-South African War and the death of Queen Victoria, as demonstrated in Statham's involvement with the Auckland branch of the Victoria League established in 1909. Finally, the chapter turns back to Robley in London, who captures the dual locations of belonging in his experimentation with the Edwardian picture postcard medium.

\footnotetext{
111 'National Repatriation Policy for Kōiwhi Tangata and Associated Burial Taonga within Aotearoa', Museums Aotearoa, 24 June 2021; https://www.museumsaotearoa.org.nz/publications/repository/national-repatriationpolicy-koiwi-tangata-and-associated-burial-taonga; accessed 13 June 2021.
} 
The third chapter concerns the period between 1914 and 1923 in which all three of the historymakers collaboratively focused on the memory of the colonial period and how to formalise it into an enduring public historical narrative. The discussion begins by looking at the first few years of Statham's government position as inspector of old soldier graves then turns to the flurry of $50^{\text {th }}$ anniversaries of colonial battles in 1914, in which all three would be involved. With the war getting underway in the same year, the discussion will consider how this impacted the framing of colonial memory by each history-maker. After analysing some of the 'historical' decision making of Statham in her work, the discussion then considers how Cowan's government position came about from the end of 1917. The discussion then explores Robley's heightened engagements with New Zealand soldiers and even hosting the Prime Minister in London due to the ongoing war effort in Europe. The chapter then returns to the letter that has introduced this thesis and looks at Robley's push to be involved in the history-making in New Zealand, both as author and as subject. The discussion ends at the publication of The New Zealand Wars, with a brief look at the some of the key themes as they relate to those put forth by Statham and Robley.

The final chapter examines how Cowan, Statham and Robley's histories were received in the years in which new attitudes towards scholarship and modernity were taking hold. Beginning with Cowan after The New Zealand Wars was published, the chapter charts his continuing governmentfunded publications on Māori history and travel topics up until 1930. Turning to Statham within the same period, the discussion includes a look at her final activities with the government, refurbishing the gravesite at Rangiriri from 1925. By this time, Robley was aging, and the next part of the discussion considers the ways in which he reconsidered his legacy in those final years before his death in 1930 . The last section of the chapter considers how Statham and Cowan's later work contrasted with and was increasingly surpassed by new ideas of modernity and remembering of the past. This was most evident in their marginal position in the preparations for the 1940 centennial celebrations. 


\section{Chapter One \\ Inroads to Maoriland: Personal Experience, Nostalgia, and Situating Self Within the Colonial Period 1863-1901}

Between 1911 and 1923 James Cowan, Edith Statham, and Horatio Gordon Robley formalised a set of historical narratives of New Zealand's colonial period. By the time Cowan had published the second volume of his New Zealand Wars history in 1923, he was 53, Statham was 70 and Robley was 83. That is to say that all three history-makers had been alive during the period which they were drawing into their nascent New Zealand histories. For each of them, the wars of the 1860s - what we now know as the New Zealand Wars - was central to their interests. But their proximity to those events and peoples that they would come to include in their narratives differed greatly. This chapter asks: what were Cowan, Statham and Robley's personal experiences of New Zealand's colonial period? How were their individual experiences and personal memories related to place and proximity to the wars with iwi in the North Island? The discussion will also consider the sources which we have for knowing about the history-makers' colonial experiences and how this informed their later portrayals of the period. As Pierre Nora argues in his theoretical analysis of the relationships between memory, history, and the nation, 'memory is by nature multiple and yet specific; collective, plural, and yet individual. History on the other hand, belongs to everyone and to no one, whence its claim to universal authority.' ${ }^{1}$ The purpose of this first chapter is therefore to explore the individual memory and experience of Cowan, Statham and Robley in order to identify the subjectivities at the heart of their portrayals of the historical past.

The 'colonial period' is generally used to define the period of New Zealand's history from the signing of the Treaty of Waitangi in 1840 to around about 1907 when New Zealand became a Dominion. All three history-makers 'arrived' in New Zealand in this period: Edith Statham in Dunedin in 1863, Horatio Gordon Robley followed shortly after in 1864, and James Cowan whose 'arrival', or rather his birth, followed in 1870. The colonial period of our discussion encompasses the concept of settlement, but also New Zealand as a colonial outpost, a place of temporary visitation. Settlement refers, on the one hand, to physical migration and establishment of new communities. But in this chapter it also concerns what Avril Bell has described as 'the narratives of peoplehood and belonging' in the

\footnotetext{
${ }^{1}$ Pierre Nora, 'Between Memory and History: Les Lieux de Mémoire’, Representations, No. 26, Spring 1989, p. 9.
} 
familiarising of place in the colony. ${ }^{2}$ As the collective experiences of the three history-makers delineated in this chapter suggest, narratives of belonging to New Zealand in the colonial period are not just about making a home in the new land. As settler colonial theorist Lorenzo Veracini explains, while colonial and settler colonial narrative forms are structurally distinct, they often interact and overlap with one another. ${ }^{3}$ 'Colonialism reproduces cycles of oppositions between civility and barbarism; colonialism immobilises relationships and establishes a pattern of repetition. In marked contrast, settler colonialism mobilises peoples in the teleological expectation of irreversible transformation. ${ }^{4}$ Together, the narratives surrounding Cowan, Statham and Robley's colonial movements and engagements exemplify the coexistence of these colonial and settler colonial structural purposes. In other words, the exploration of Cowan, Statham and Robley's personal colonial experiences will demonstrate their collective considerations of belonging as a part of settlement as well as belonging to empire.

The chapter is structured around the chronological order in which Statham, Robley and Cowan 'arrived' in the colony. The first section will consider Statham's experience following her arrival at the settlement of Dunedin from 1863. Unlike Cowan and Robley, Statham's colonial experience is observed through her presence in local newspaper reporting rather than through her own recollections. The reports nevertheless exemplify narratives around settlement and settler polities, particularly in her specific context of Dunedin. I will begin with a discussion of the British perceptions of Dunedin as an idealistic location for settlement, along with the ways in which this perception was challenged. After discussing Statham and her family's social status and her occupational trajectory, the first section will then analyse Statham's most prolific period of activity in Dunedin as a 37 to 47-year-old between 1890 and 1900. The analysis of this period will demonstrate the ways in which Statham's progressive female identity was significant in creating an exemplary new world settlement in Dunedin, particularly when she engaged in movements promoted as part of social betterment. At the close of the decade, Statham's departure from Dunedin to assist New Zealand's contingent in the Boer War will ultimately demonstrate the extent to which her view of female citizenship and social betterment was intimately tied to imperial ideology.

The second and third sections of the chapter considers the experiences of Robley and Cowan who followed Statham in 1864 and 1870, respectively. However, before their experiences can be brought into a discussion with Statham and her presence in contemporary newspaper reports, the discussion will begin by explaining the sources of information we have about their experiences. Unlike Statham, both Robley and Cowan presented their own experiences through recollections written in the

\footnotetext{
${ }^{2}$ Avril Bell, 'Bifurcation or Entanglement? Settler Identity and Biculturalism in Aotearoa New Zealand', Continuum, Vol. 20, No. 2, 2006, p. 256.

${ }^{3}$ Lorenzo Veracini, 'Telling the End of the Settler Colonial Story', in Fiona Bateman and Lionel Pilkington (eds.), Studies in Settler Colonialism: Politics, Identity and Culture, (London: Palgrave Macmillan, 2011), p. 205.

${ }^{4}$ Ibid, p. 207.
} 
years following the end of the Great War in 1918. This timely detail will be important for understanding how their experience, often focusing on their relationships with Māori and Māori culture, were simultaneously interested in the cultural relationship with empire. This difference in how we have come to 'know' each of the three history-makers also makes for a salient point of reflection about the gendered nature of who is writing autobiographically at this time. The second section continues with Robley's recollection of his soldier experience in what he termed as 'the land of the Maori', during the New Zealand Wars. The discussion then looks at his experience upon his return to England, with the inclusion of sources outside of his own recollections. In particular, it will look at his foray into ethnology through his collection of mokomokai and how this garnered him a sense of expertise around the Māori past and the ability to describe its value to settler belonging in New Zealand.

The third and final section of the chapter looks at Cowan's childhood, a story of settlement in the Waipa Valley of the Waikato that deeply contrasts Statham's experience in Dunedin. Unlike Statham, Cowan's colonial experience became an ongoing point of reference for him in his publications on New Zealand and Māori history. The discussion goes on to explore Cowan's own journey of using his experience with Māori in his childhood to garner a sense of expertise in the field of Māori affairs when, in 1888, he moved to Auckland to begin a career in journalism. The discussion then considers the journalism field in 1890s Auckland and how this facilitated Cowan's populist reputation as an expert on Māori topics. The chapter ends at the climactic moment of Cowan's growing reputation when he was hired by Henry Partridge in 1901 to write the accompanying biographies to Gottfried Lindauer's exhibition of Māori portraits.

Edith Mary Statham was born on 13 April 1853, in Liverpool, England and at the age of ten she moved with her parents, William Statham and Ellen Hadfield, and three younger brothers to New Zealand, arriving aboard the Venus to Dunedin in $1863 .{ }^{5}$ As historian Erik Olssen has illustrated, settlement in Otago had long been part of a vision of a 'New World garden' particularly by entrepreneur, pamphleteer and founder of the New Zealand Company, Edward Gibbon Wakefield. ${ }^{6}$ The arrival of the first two emigrant ships in 1848, having been funded by the Scottish Presbyterian Lay Association testified to the inherently religious tone of such the vision for Otago settlement. ${ }^{7}$ By the time the Statham family would have been made aware of Otago settlement the region had accumulated a substantial amount of wealth, first through the pastoral industry and then by 1861 through the discovery of gold. ${ }^{8}$ Advertisements for Otago settlement in Britain from the 1850s focused on the 'arcadian' beauty and abundance of resources, captivating desires for potential material accumulation but without the moral

\footnotetext{
${ }^{5}$ Phillips, To the Memory, p. 35.

${ }^{6}$ Erik Olssen, A History of Otago, (Dunedin: John McIndoe, 1984), p. 31.

${ }^{7}$ Ibid, p. 33.

${ }^{8}$ Ibid, pp. 55-56.
} 
decay of the old world cityscape. ${ }^{9}$ Prior to the gold rush influx, 'health of the body' was one of the most stated reasons given by settlers for choosing to settle in Dunedin, the nature and climate of the area, along with the promise of 'moderate labour' instead of the toil of urban space in Britain. ${ }^{10}$ The idea that the New Zealand colonies were ideal, healthy places to live remained pervasive throughout the first few decades of settlement. As Barbara Brookes argues in her exploration of gender and health in Southern Dunedin, a report on the statistics of New Zealand 1889 claimed that 'the death rate in New Zealand contrasts very strikingly with those in the other Australasian colonies and with European countries, and furnishes evidence of the great salubrity of the climate of the colony.' ${ }^{11}$

Unlike their settling counterparts in Taranaki and other areas of the North Island, this idealisation was not as challenged by local iwi and hapu willing to take up arms to defend their land and sovereignty. When settlers first arrived in the Dunedin/Port Chalmers area, Kāi Tahu Māori resided predominantly near the Taiaroa Heads near the harbour entrance, on the Taieri Plains to the south or at Waikouaiti to the north. ${ }^{12}$ As Dunedin began to form as a urban hub, Māori were absent from electoral data, which was due to in part to the continuance of rural living in that area as well as early assimilative measures around surnames that might present Māori as European on paper. ${ }^{13}$ Nevertheless, settlement in Dunedin was notable for its monoculturalism and overwhelming Scottish origins of the majority. ${ }^{14}$ However, there were alternate ways in which the settler dream of an Arcadia in Otago was undermined. As Dunedin grew, predominantly due to the sudden and massive influx of miners and the wealth acquired from the Otago goldrush of the early 1860s, so too did the risk it presented for the health of settlers. ${ }^{15}$ As Pamela Wood has argued, from the 1860s, the time of the Statham family's arrival, the streets were often caked with unsightly mud and with an insufficient sanitation and rubbish system, the sight of the Dunedin streets prior to the 1890s suggested that even a city in the new world had the potential to regress into urban decay. ${ }^{16}$ It was these moments of dirtiness along with outbreaks of disease throughout the community, Wood argues, that threatened to undermine the originating ideas and actions upon which the Otago settlement had been founded. ${ }^{17}$

There is not a wealth of information about the Statham family's activities in Dunedin during these early years, but some indication can be drawn from Statham's obituary and local newspaper reporting. According to Jock Phillips, Statham's father William worked as a solicitor in Dunedin. ${ }^{18}$ As

\footnotetext{
${ }^{9}$ Wood, p. 17.

${ }^{10}$ Ibid, pp. 20-21.

${ }^{11}$ Barbara Brookes, 'The Risk to Life and Limb’, in Brookes, Cooper and Law (eds.), Sites of Gender, p. 288.

12 Wood, p. 18.

${ }^{13}$ Annabel Cooper, Erik Olssen, Kirsten Thomlinson and Robin Law, 'The Landscape of Gender Politics: Place, People and Two Mobilisations’, in Brookes, Cooper and Law (eds.), Sites of Gender, pp. 36-37.

${ }^{14}$ Ibid.

${ }^{15}$ Wood, p. 7.

${ }^{16}$ Ibid, pp. 33, 51.

${ }^{17}$ Ibid, p. 161.

18 Phillips, 'Statham, Edith Mary', DNZB, Te Ara, 1996; https://teara.govt.nz/en/biographies/3s32/statham-edithmary; accessed 15 May 2021
} 
for Statham's brother Charles, he too served as a solicitor and was actively involved in the local Anglican diocese, suggesting that the Statham family, being both English and Anglican, were in the minority of the predominantly Presbyterian Scottish settlement. ${ }^{19}$ Little is known about the details of the Statham children's education but according to Statham's obituary, she at some point trained as a singer and dabbled in amateur acting, then taking up private nursing after training at Dunedin Hospital. ${ }^{20}$ As Patricia Sargison has noted, from 1882 pupil nurses would begin at the hospital under rather haphazard conditions and only a few would end up being appointed at the hospital itself, which might explain Statham's transition to 'private' nursing. ${ }^{21}$ Aside from this detail from her obituary and a couple of early recitals reported on in during the 1870s, Statham's activities are harder to trace from this time. ${ }^{22}$ That is until in May 1890, when it was reported in the Evening Star that 'Misses Statham and Rigg', two 'surgical nurses' had moved from Waiwera, north of Auckland, to a residence on Cumberland Street in the centre of the Dunedin township. ${ }^{23}$ Statham's obituary would later mention that she had struggled with (unidentified) health issues as a nurse, so it is possible that she had been staying at the Waiwera hot springs to alleviate her symptoms. ${ }^{24}$ It should also be mentioned that Rigg, or Emily Rigg as she appears in the Stone's directory, appears frequently in the records of Statham's time in Dunedin and briefly later on, but little is known of her life outside of these records. ${ }^{25} \mathrm{It}$ is hard to know whether Statham as a private, surgical nurse was categorised within more of a domestic work realm, or something more akin to the increased social authority of nursing after the Nurses Registration Act $1901 .{ }^{26}$ By 1890, Statham was a 37 year-old single working woman, which indicated a degree of autonomy.

It was the period between Statham's return to Dunedin in 1890 from Waiwera and her departure from the city in 1900 that the most defining moments of Statham's colonial experience occurred. Before detailing Statham's actions during this time, some further contextualisation of this period is required. Settlement in Dunedin had always strived to be 'antidotal' to poverty and social evils of the British old world, and from the late 1880s mobilisations to address those social issues became significant in the city. ${ }^{27}$ Statham's return in 1890 could not have come at a more pivotal time. By 1890 Dunedin was the colony's most industrialised city and it was home to the Union Shipping Company, the largest of its

\footnotetext{
${ }^{19}$ Olssen, A History of Otago, p. 40.

${ }^{20}$ Phillips, To the Memory, p. 35; 'Obituary', ODT, 15 February 1951, p. 9.

${ }^{21}$ Patricia Sargison, 'Gender, Class, and Power: Ideologies and conflict during the transition to trained female nursing at two New Zealand hospitals, 1889-95’, Women’s History Review, Vol. 6, No. 2, 1997, p. 186.

${ }^{22}$ See 'Good Templar Soiree', ODT, 2 September 1875, p. 3.

${ }^{23}$ ES, 3 May 1890 , p. 3.

24 ‘Obituary’, ODT, 15 February 1951, p. 9; Margaret McClure, The Wonder Country: Making New Zealand Tourism, (Auckland: Auckland University Press, 2004), p. 13.

25 'Emily S. Rigg', Stone’s Directory, 1900, ‘Edith Mary Statham’, Ref. File 438, Sir George Grey Special Collections, Auckland City Library, Auckland (GGSC).

${ }^{26}$ Erik Olssen, 'Working Gender, Gendering Work: Occupational change and Continuity in Southern Dunedin', in Brookes, Cooper and Law (eds.), Sites of Gender, p. 75.

${ }^{27}$ Cooper, et. al., 'The Landscape of Gender Politics', p. 41.
} 
kind in Australasia. ${ }^{28}$ It was also a year of major strike action. The launching of the Maritime Council in Dunedin in 1889 had led to a colony-wide strike against the Union Shipping Company's inaction in 1890 during Australian strikes. ${ }^{29}$ But in Dunedin these mobilisations took on particularly gendered considerations. Due to a variety of demographic and economic reasons, Dunedin by the early 1890s had become a primary centre of women's suffrage agitation, with 57 per cent of Dunedin's female population signing the 1893 petition for suffrage. This contrasted with 25 per cent of the overall New Zealand female population. ${ }^{30}$ There was some convergence between female suffrage mobilisations and predominantly male union activity; the 1889 Tailoresses union, organised by prominent local men and headed by suffragist Harriet Morison, exemplified the overlapping concerns for female equality and improving working conditions for all workers. ${ }^{31}$ However, the predominantly male nature of the early Dunedin union movement, could also work to marginalise women in the new politics of social class, particularly for those who viewed the quest for sufficient working conditions and pay as part of the male breadwinners ability to provide for his family. ${ }^{32}$ As Cooper, Olssen, Thomlinson and Law have argued, local ‘working men's' paper, the Workman actively opposed women's suffrage and the influx of women into the paid workforce. ${ }^{33}$ While Statham's work as a private nurse, most probably lay outside this reproach, these attitudes demonstrates that even in this progressive context, there were many in society who viewed a woman's place as being in the household. This is important to remember when considering all the ways Statham would step out into the public realm in her subsequent years.

After Statham moved back to Dunedin, she became intimately involved in political activity and agitation. In October 1893, a month after women had won the right to vote, Edith Statham was listed in the Otago Daily Times as a member of the newly formed Women's Franchise League, with Marion Hatton at the helm. ${ }^{34}$ By April of the following year, six months after New Zealand women had the chance to vote in their first election, Statham was advertising the League's meeting under the title of 'honorary secretary. ${ }^{35} 1894$ was also the year that Statham appeared to move into what Erik Olssen identifies as 'white blouse work' as a freelance typist, placing regular advertisements in the Otago Daily Times for the services she conducted from an office at 27 Princes Street in the city. ${ }^{36}$ Her obituary later stated that Statham had taken up clerical work because of health issues, though it could be suggested that typist work as part of women's occupational frontiers was an attractive change from nursing that often could err on the side of domestic work, an area that Olssen suggests was becoming unpopular for

\footnotetext{
28 Ibid.

${ }^{29}$ Mark Derby, 'Strikes and labour disputes - Early labour disputes', Te Ara, 2011; http://www.TeAra.govt.nz/en/strikes-and-labour-disputes/page-2; accessed 20 June 2021.

${ }^{30}$ Cooper, et. al., 'The Landscape of Gender Politics', p. 44.

${ }^{31}$ Ibid. p. 41.

32 Olssen, A History of Otago, pp. 86-88.

${ }^{33}$ Cooper, et. al., 'The Landscape of Gender Politics', p. 44.

34 'The General Election’, ODT, 20 October 1893, p. 2.

35 ES, 3 April 1894, p. 3.

${ }^{36}$ ODT, 7 June 1894, p. 3; Olssen, A History of Otago, pp. 71-72.
} 
women by the 1890s. ${ }^{37}$ Nevertheless, obtaining an office and presumably a typewriter gave Statham ample opportunity to spread the Franchise League's agenda in the form of letters to the editor. ${ }^{38}$

Edith Statham was also active in a wide range of interests that further demonstrate her embodiment of progressive female citizenship alongside her political organising and typist business. As local reports indicate, Statham was also engaged in ladies cycling and the debates around health and wellbeing, along with the formation of the colony's 'new woman' ideal in the 1890s period. Across Britain and the imperial colonies, female cycling, amongst other activities of women's leisure activities were on the rise in this decade. ${ }^{39}$ But as Brookes, Olssen and Beer have demonstrated in their work on leisure, gender and modernity in Dunedin from 1890, female cycling operated within a particular discourse around how forms of leisure were seen as conducive to or in hindrance of the livelihood of the community. ${ }^{40}$ As Catharine Coleborne and Ondine Godstchalk argue in their exploration of family health in the Australasian colonies from 1850 to 1910, middle-class and upper-class women like Statham 'were often at the forefront of the creation of colonial cultures of health. ${ }^{41}$ Statham was acutely aware of health and wellbeing in the settlement. Having already travelled to Waiwera for a unknown illness in c. 1890, Statham reportedly suffered a bout of severe influenza in $1895 .{ }^{42}$ During 1895 , Statham's advertisements for her typing services were replaced with requests for a 'health and seaside resort' for her to stay at. ${ }^{43}$ The health of settler women was of particular interest during this time. When it came to how they engaged in leisurely activity this often sparked debate about how certain sports impacted a woman's fertility, particularly in New Zealand where the Pākehā birthrate was plummeting between 1881 and $1901 .{ }^{44}$ While this may not have been a concern for Statham herself given her singlestatus, it did impact on the discourse around female participation in sports like cycling. Nevertheless, as Brookes, Olssen and Beer have noted, throughout the 1890s, the rhetoric moved away from the fear for the negative impacts of sporting activity on a woman's health and fertility, to the idea that fitness was essential to discharging a woman's 'reproductive duties', a concept championed in the early work Dr Truby King at Otago University. ${ }^{45}$ Along with her occupational developments, Statham's

\footnotetext{
${ }^{37}$ Olssen, A History of Otago, p. 73; 'Obituary’, ODT, 15 February 1951, p. 9.

38 Edith M. Statham, 'The Women’s Franchise League’, ES, 11 August 1894, p. 1.

${ }^{39}$ Beata Kiersnowska, 'Female Cycling and the Discourse of Moral Panic in Late Victorian Britain', Journal of the Spanish Association of Anglo-American Studies, Vol. 41, No. 2, 2019, pp. 91-92.

${ }^{40}$ Barbara Brookes, Erik Olssen and Emma Beer, 'Spare Time? Leisure, Gender and Modernity', in Brookes, Cooper and Law (eds.), Sites of Gender, pp. 151-189.

${ }^{41}$ Catharine Coleborne and Ondine Godtschalk, 'Colonial Families and Cultures of Health: Glimpses of Illness and Domestic Medicine in Private Records in New Zealand and Australia, 1850-1910’, Journal of Family History, Vol. 38, No. 4, 2013, p. 406.

42 'Cycling Notes', ES, 1 February 1896, p. 2 (supp.).

${ }^{43}$ ES, 6 November 1895, p. 3.

${ }^{44}$ Cooper, et. al., 'The Landscape of Gender Politics', p. 25.

45 Brookes, et. al., 'Spare Time? Leisure, Gender and Modernity’, p. 166.
} 
contributions to Dunedin's culture of bicycle riding put her in a decisive position to help foster a sense of health and vitality in the colony's new form of femininity. ${ }^{46}$

Across 1895 and 1896 Statham appeared in local reports as a founding member of the newly formed 'Mimiro Cycling Club' for ladies. In an initial report in August 1895 it was stated that the members had 'unanimously' elected to name their club after a Māori word, 'mimiro' citing its meaning of swift movement. ${ }^{47}$ The first meeting was held at Statham's home, where the members agreed that they did not wish to compete in racing but to foster 'cycling among ladies' as a means of pleasant enjoyment and recreation. ${ }^{48}$ Other reports made mention that Statham's office building on Princes St was used by those ladies out for a 'recreational' ride to store their bicycles. ${ }^{49}$ In October 1895, the Evening Star reported that Statham, as 'hon. secretary' of the ladies cycling club, had expressed gratitude for the 'warm interest' taken in the club from the general public after the cycling ladies had experienced the jeering 'malignant attentions of the larrikin class. ${ }^{50}$ What these reports suggested was that female participation in cycling was to be done in a manner that maintained upper-class feminine respectability, racing was out of the question. ${ }^{51}$ It also appears that the cycling ladies had received some verbal abuse from while riding in public but that the 'general public' was predominantly supportive of their recreational cycling. ${ }^{52}$ The connection between cycling, suffrage, social mobility and the wellbeing of the community was further exemplified by Statham when it was reported from 1897 that she and Rigg had begun to operate a bicycle business, selling imports from Britain and the United States. ${ }^{53}$ At the same time, Statham and Rigg had also opened their own department store in the old Colonial Bank Buildings, a venture that was praised in the Otago Witness because 'the fact that they have also been nurses will ensure promptitude in the dispatch of any business relating to sickness. ${ }^{54}$ While little more is known of these business ventures beyond these newspaper reports, they serve as further reminders of Statham's relentless pursuit of a progressive female citizenship. Whether it be through the community concerns of health and wellbeing, or egalitarian politics, Statham was eager to take up new opportunities and was energetic in her pursuits.

Statham's colonial experience was exemplary of the 'program of progress' of 'new world' democracies, distinguished from the old world by their labour reforms, women's rights and community organisations for social betterment. ${ }^{55}$ This settler colonial vision is perhaps emphasised by the fact that aside from the Māori name of Statham's cycling club, there is little semblance of a Māori presence in

\footnotetext{
${ }^{46}$ Ibid, p. 165.

47 'Cycling', Otago Witness (OW), 8 August 1895, p. 35.

48 Ibid.

49 'Notes by Demon', OW, 3 October 1895, p. 35.

50 'Cycling Notes', ES, 5 October 1895, p. 1 (supp.).

${ }^{51}$ Brookes, et. al., 'Spare Time? Leisure, Gender and Modernity’, p. 165.

${ }^{52}$ Ibid.

${ }^{53}$ ES, 7 August 1897, p. 3.

${ }^{54}$ OW, 19 August 1897, p. 43.

${ }^{55}$ Lake, pp. 12, 18.
} 
this vision at all, let alone one that might challenge the idealism of a new world society like Statham's. ${ }^{56}$ Yet for all of this new world distinction, it did not mean that Edith Statham and her contemporaries in Dunedin, as in New Zealand as a whole were uninterested or uncommitted to the wider empire.

The first indication that Statham saw her work within a frame of imperial allegiance was in a June 1897 letter to the editor of the Evening Star entitled 'Public Library vs. Children's Ward. ${ }^{57}$ The letter concerned a sum of money that had been publicly collected in Dunedin in preparation for Queen Victoria's Silver Jubilee to be celebrated in March of the following year. It had been planned that the sum of money would be put towards a public library in 'celebration of the record reign.' Statham disagreed:

I feel that it is not quite in accordance with the expressed wish of our Most Gracious Majesty, who has always had the greatest sympathy with the poor and suffering. It is her wish that all the money collected for memorials of this most peaceful reign shall take the form of hospitals or something akin to them... That, I think, would be the most suitable way of celebrating that most important event in the history of Otagonians. ${ }^{58}$

The letter appeared to typify what Marilyn Lake terms as the 'politics of maternalism' that formed a strand of suffrage agitations in New Zealand as with elsewhere in new world societies. ${ }^{59}$ As Lake argues, these 'politics' could be deployed to serve a range of political causes, and posited white women reformers as 'central to fashioning new kinds of maternalist welfare states. ${ }^{\text {, } 00}$ This maternalistic strand of suffrage arguments is key to understanding how elite white women in former British colonies like New Zealand started turning towards Queen Victoria as example of 'the ultimate maternal icon' towards the turn of the twentieth century. ${ }^{61}$ On the one hand Statham's philanthropic work with the Society for the Protection of Women and Children from 1899 seems to support the link between Statham's progressive female identity, maternal welfare and imperial sentiment. ${ }^{62}$ However Statham was a single woman, who up until this point had focused on her own economic and leisurely freedoms rather than promoting her own role as a mother. It is most likely that in this example, Statham’s concerns as a former nurse, happened to align with the ‘expressed wish’ of Queen Victoria’s concerns for social welfare.

The most definitive moment in which Statham's developing civic role was translated into imperial allegiance was in 1899 when the empire went to war with the Boers in the Transvaal, South Africa. In December 1899, two months after the war was announced and Premier Richard Seddon had

\footnotetext{
56 Ibid, p. 14.

${ }^{57}$ Edith Statham, 'Public Library vs. Children’s Ward', ES, 3 June 1897, p. 3.

${ }^{58}$ Ibid.

${ }^{59}$ Lake, p. 178.

${ }^{60}$ Ibid, p. 176.

${ }^{61}$ Pickles, 'The Victoria League in New Zealand', p. 29.

62 'Charitable Aid Board', ES, 16 February 1899, p. 3.
} 
offered assistance, it was reported in the Otago Daily Times that Statham and Rigg had organised a 'corps of ladies' to manufacture 'badges of the national colours' at a patriotic fundraising meeting. ${ }^{63}$ Statham and Rigg's organised manufacturing of the badges, to be sold 'for the benefit' of the patriotic fund, was described in the report as a 'yeoman service', capturing the distinction of women of the new world in imperial duty. ${ }^{64}$ The report also included a congratulatory message from Seddon himself: 'Hearty congratulations on the success of last night's meeting. Loyalty and patriotism of the people in the emergency will be most gratifying to our kindred at Home, and will inspire the respect of other nations.' 65 The Mayor of Dunedin, Robert Chisholm, published his response to the Premier, that Dunedin had 'love and loyalty to the mother country' and that 'a high sense of duty to the Empire had moved the citizens of Dunedin to rise to the occasion.' 66

But organisational 'yeomanry’ was merely the tip of the iceberg of Statham's sense of imperial allegiance. Two months earlier when the war had been declared, Statham and Rigg volunteered for service as nurses with the New Zealand contingent being sent to the Transvaal. ${ }^{67}$ This was despite, in Statham's case, having retired from nursing for at least five to six years. In January 1900, the report came back from Wellington that Statham and Rigg's offer had stood alone and that only in the event that 'a number' of nurses volunteered would the government provide the expenditure for their travel to South Africa. ${ }^{68}$ Throughout the following months a small number of nurses from around New Zealand had added their names to the list of women willing to accompany the New Zealand contingent. ${ }^{69}$ By March it appeared that there was some confusion over whether the 'Imperial Authorities' would approve the New Zealand nurses' service but that a sufficient number had applied to garner the government's support. $^{70}$ Nevertheless, the general public rallied around the volunteer nurses, particularly in Whanganui where the Ladies Committee had gathered enough funds to pay for the transport of seven local nurses. ${ }^{71}$ In April it was reported in the Otago Witness that Statham and Rigg had not been selected to have their transport to the Transvaal funded, but that 'a number of friends clubbed together' to raise the funds needed for their passage. ${ }^{72}$ At the fundraising event, Mayor Chisholm lamented the loss of the two women saying that they were 'well-known figures in Dunedin', having done 'excellent work' in the city and would be missed. ${ }^{73}$ On 2 June 1900, Statham and Rigg departed on the steamship Te Anau bound for Auckland, presumably where they would transfer to a ship destined for the Transvaal. ${ }^{74}$

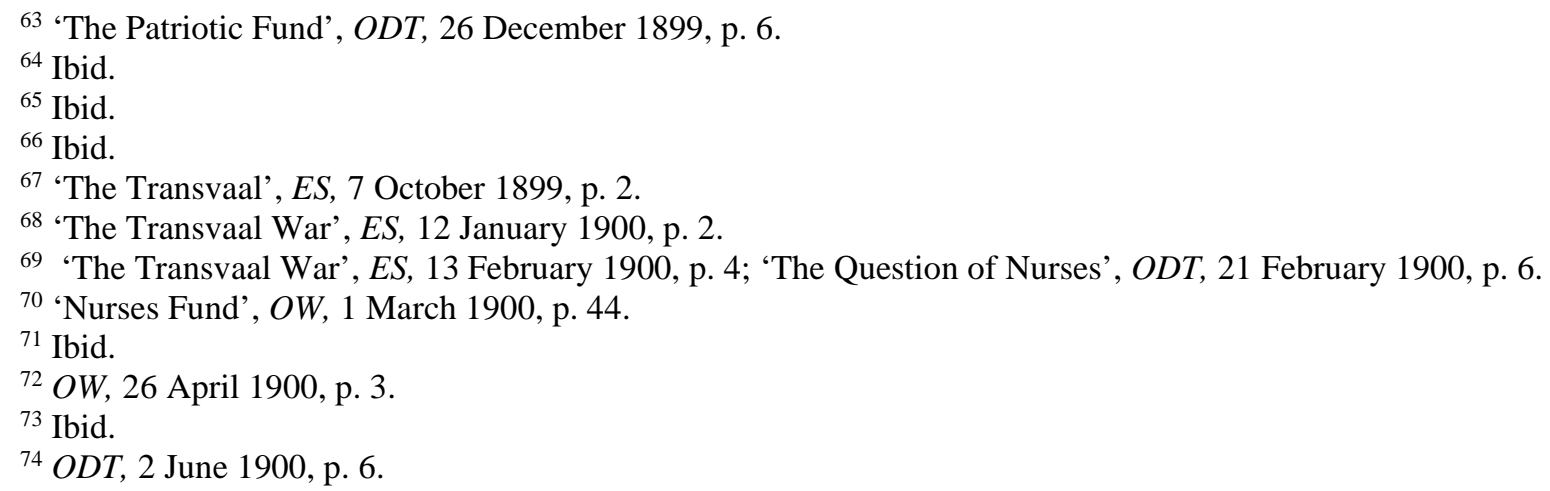


Apart from the series of public farewells Statham and Rigg's names did not feature in any further local New Zealand news. ${ }^{75}$ There were no reports of their arrival in South Africa nor any reports of them aiding the frontline. In October 1900, Statham's name did reappear, not in a cable from the battlefield but in a report from the Auckland Star announcing her appointment as assistant secretary of the Auckland Cycle Roads League. ${ }^{76}$ In February 1901, Statham was elected as the secretary of the Auckland branch of the Women's Christian Temperance Union (WCTU), another organisation she had previously been involved in Dunedin. ${ }^{77}$ It appeared that when Statham and Rigg arrived in Auckland, they had stayed there, rather than going on the South Africa. It is unclear why they never went on to the Transvaal. It may have been that those imperial authorities Seddon had referred to never gave their approval for the nurses' passage to the Transvaal, or that their retirement from nursing had made them less qualified than other nurses. As John Crawford and Ellen Ellis have articulated in their work on New Zealand's role in the South African War, the imperial front was in dire need of medical aid, and that Statham and Rigg were not the only New Zealand nurses were eager to serve, but in the end only 35 nurses had been sent to South Africa. ${ }^{78}$ Equally possible is that upon arrival in Auckland Statham saw an opportunity to improve local society in the same ways she had in Dunedin. As Cooper, Olssen, Thomlinson, and Law have argued, unionism, the WCTU and suffrage action in Auckland were comparatively weak compared to the Dunedin mobilisations. ${ }^{79}$ Whatever the reason, Statham may not have gone to the Transvaal, but she showed no signs of relinquishing her female imperialist agenda. In a letter to the editor of the Auckland Star in January 1902, referencing the ongoing tensions between Britain and Germany, Statham proposed the creation of a women's league for the boycott of German goods, as had been done in Oamaru:

'Sir, allow me to respectfully suggest to my fellow citizens of the gentler sex the advisability of forming ourselves into a league and taking action on the lines of our honoured friends in little Oamaru. Let us take a vow to uphold the dignity, etc., of our Empire... I think that a league or union should commence in Auckland, the home of many brave men who have fought for our noble Queen and country, and in the veins of whose descendants the warm blood of affection and patriotism is flowing still. ${ }^{80}$

With that call to action, Statham marked the beginning of a new era in her organisational work, rallying around 'noble Queen and country', a sentiment that led to the formation of the Victoria League. It was this League which was to occupy a central role in the rest of Edith Statham's life.

\footnotetext{
75 'Women’s Christian Temperance Union', ES, 27 June 1900. P. 7; ‘Women and Children’s Protection Society’, ES, 31 July 1900, p. 5.

76 'Amusements', Auckland Star (AS), 4 October 1900, p. 8.

77 Untitled, AS, 15 February 1901, p. 4.

78 John Crawford, Ellen Ellis, To Fight for the Empire, (Auckland: Reed books, 1999), pp. 41-42.

79 Cooper, et. al., 'The Landscape of Gender Politics', p. 44.

${ }^{80}$ Edith Statham, 'To the Editor', AS, 17 January 1902, p. 3.
} 
The colonial experiences of Horatio Gordon Robley and James Cowan are markedly different from that of Statham's in Dunedin, and so are the sources from which we can glean their biographical information. Unlike Statham, how we know of Robley and Cowan comes from both the usual range of biographical sources, and, crucially, from biographical recollections they wrote later in their lives. For both, recalling their accounts of their colonial formation were central. Robley's autobiographical information comes from the series of notes given to Horace Fildes in 1919. Fildes, in turn, compiled them into an unpublished biography, that largely retains Robley's narrative voice. ${ }^{81}$ Cowan's memoirs appear in multiple publications, particularly from the 1930s.

Robley's colonial experience in New Zealand was formed by being plunged into the conflict with Māori in Tauranga as an ensign in the British army, at the height of hostilities in the New Zealand Wars. Horatio Gordon Robley was born in Madeira, Portugal on 28 June, 1840 to retired British army officer John H. Robley and local artist, Augusta J. Robley. ${ }^{82}$ As Fildes later put it, this parentage was influential in setting his own direction; 'for a future career young Robley's inclination was for the Army, and so followed the vocation of his father. It will thus be seen that from his paterfamilias he had implanted in him a preference for Bella! Horrida Bella! And from his mother he inherited a worship of les beaux arts..., 83 At the age of eighteen, Robley did follow in his father's footsteps by purchasing an ensignship in the British army and within the year was traveling as part of the $68^{\text {th }}$ regiment to India aboard the Colgrain. ${ }^{84}$ After ' 126 days' in Madras, Robley and the regiment departed to escort Sepoys to Rangoon in Burma after the siege of Delhi where Robley also took charge of the guard of the exiled Mogul Emperor, Bahadur Shah II. ${ }^{85}$ While Robley was in Burma, an outbreak of war had been announced in New Zealand, drawing about 6,000 troops from across the Empire in the first two years. ${ }^{86}$ By late 1863, the war had escalated in the Waikato and Robley's regiment was ordered from Burma to proceed on active service. On 8 January 1864 the $68^{\text {th }}$ regiment sailed into Waitemata Harbour:

The troops were conveyed from ship to shore by the cutters and launchers of H.M. ships Curacoa and Esk... Proceeding along Queen St we entered Albert Barracks square where we found that some members of the $65^{\text {th }}$ regiment had pitched fifteen tents for our reception on Barracks Green, twenty men being accommodated to each tent. It was thus that I landed in the land of the Maori, a country I was quickly to find a grand place to get to. ${ }^{87}$

\footnotetext{
${ }^{81}$ Walker, 'Robley: Te Ropere 1840-1930’, p. 2.

${ }^{82}$ Walker, 'Robley: Te Ropere 1840-1930’, p. 3.

${ }^{83}$ Fildes, 'Major General H. Gordon Robley: Soldier and Artist', 1921, Fildes MSS 1507, JCBR, p. 4.

${ }^{84}$ Horatio Gordon Robley, ‘Army Service from 1858’, c. 1919, FILD00056, JCBR, p. 1.

${ }^{85}$ Ibid; Johannes Andersen, 'Obituary: Horatio Gordon Robley, 1840-1930’, The Journal of the Polynesian Society, Vol. 40, No. 1, March 1931, p. 39.

${ }^{86}$ Andersen, p. 39.

${ }^{87}$ Fildes, 'Major General H. Gordon Robley: Soldier and Artist', c. 1919, FILD00057, JCBR, p. 15.
} 
'The Land of the Maori' was the most central aspect of Robley's 1919 narrative of his military career and he made sure as he recounted his experience in New Zealand, that he cast his position during the events of his stay as decisive. 'In a short time' after arriving in Auckland, Robley at the $68^{\text {th }}$ were transferred to Tauranga, landing at the Te Papa mission station where they started building redoubts. ${ }^{88}$ In the weeks leading up to the attack on Gate Pā, Robley became acquainted with the landscapes and the features of the battlefield:

[the native land was] marked by a distant hill across the peninsula... it happened that in pursuit of a duck I had gone on a long way by the shore, and I found I was accidentally on the native side of that very hill - a sketch map was drawn of how I got round - and kept to myself - When in short time the Maori came to occupy, and began their trenches and fencing - It was interesting to look with glasses at this busy working on spot I had a plan of - I then told my colonel who took me to Sir Duncan. ${ }^{89}$

The significance of this battle at Pukehinahina (Gate Pā) that Robley was situating himself in, cannot be understated. The battle was one in which 'Sir Duncan', referencing Lieutenant-General Duncan Cameron, had been in command of a major artillery attack of 1,650 men, one of which was Robley - a dominating number over the 200 Ngāi Te Rangi, Ngāti Pūkenga and Ngāti Koheriki defenders. ${ }^{90}$ For this reason, the advancement on the 'insignificant' pā site looked to the British regiments as promising of an easy defeat. That promise was quickly disproved when the British forces entered the pā and were fired upon by concealed Māori combatants from bunkers below. ${ }^{91}$ The Māori defenders had made a humiliating example of the British army, and amongst the British casualties of the failed assault was ten officers. ${ }^{92}$ As a young, 23 year old junior officer, it is no wonder this moment would loom large in his memories of his time in New Zealand.

Robley's recollections continued to emphasise his prominent position in the events, mentioning his selection as a marksman to watch over the water supply of the opposing forces the day before the battle. ${ }^{93}$ When the 'disastrous' attack took place, Robley and the $68^{\text {th }}$ had been positioned at the rear of the assault party. ${ }^{94}$ Robley would later claim that upon entering the pā after the fighting had subsided, he 'administered' rum to wounded Māori combatants, including Ngāti Tukairangi chief Reweti Manotini. ${ }^{95}$ This was also the point in which Robley made a detailed sketch of the fortifications, which he hurriedly delivered to the captain of a departing steamer, to eventually be published in the Illustrated

\footnotetext{
${ }^{88}$ Robley, ‘Army Service from 1858', c. 1919, FILD00056, JCBR, p. 6.

${ }^{89}$ Ibid, p. 7.

${ }^{90}$ Vincent O’Malley, The New Zealand Wars Ngā Pakanga o Aotearoa, (Wellington: Bridget Williams Books, 2019), pp. 137-139.

${ }^{91}$ Ibid, p. 140.

92 Ibid.

${ }^{93}$ Robley, ‘Army Service from 1858', c. 1919, FILD00056, JCBR, p. 8.

${ }^{94}$ Ibid, p. 9

${ }^{95}$ Fildes, 'Major General H. Gordon Robley: Soldier and Artist', 1921, Fildes MSS 1507, JCBR, p. 59.
} 
London News of 23 June. ${ }^{96}$ Aside from positioning himself in a potentially decisive position in what was a significant moment of defeat for the British army, this sketch of Gate Pāa, along with eight other sketches published in the Illustrated London News, did suggest that Robley held an important role in providing 'reportorial contributions' to its London readership. ${ }^{97}$ The sketches included depictions of the battle of Te Ranga six weeks later, specifically the moment of surrender at Te Papa lead by Hori Ngatai although it appears that Robley did not take part in the actual fighting on the day. ${ }^{98}$

After recounting his proximity to and decisive engagement in those significant moments in 1864 Robley went on to recount that in 1865 , he had obtained leave from the $68^{\text {th }}$ 'to join Captain Gilbert Mair N.Z.C. and his Arawa warriors' chasing after 'the fanatic tribe who drunk the blood of Rev. Mr. Volkner in his church at Opōtiki. ${ }^{99}$ Volkner's demise would become more significant to Robley's story once he had returned from service and was living within Victorian London. Nevertheless, according to Robley, this final period of his time in New Zealand was spent attending Ngāi Te Rangi events, exploring and sketching his experiences around the Bay of Plenty area. During this time, Robley began a relationship with a Māori woman from Matapihi, named Herete Mauao, and together they fathered a son, naming him Hamiora Tu Ropere, after his father. ${ }^{100}$ According to Walker, Robley continued to have a relationship with his son and grandchildren after his time in New Zealand, another significant consideration of Robley's attachment to the young colony. ${ }^{101}$ Nevertheless, by early 1866, the 68th had been called for service elsewhere in the Empire and on 14 March 1866, Robley and his regiment returned home by way of 'Cape Horn and the Azores.' ${ }^{102}$ As Robley framed it in his narrative: 'my personal connection with New Zealand was now ended and I left that fine country, the land of the Maori with feelings of upmost regret...' ${ }^{103}$ Robley then recounted that after eleven more years of service both at home and in outposts such as Mauritius, Natal and Ceylon, he retired from the military in 1887 and settled in London. ${ }^{104}$

This round journey of Robley's as a soldier was exemplary of a romantic colonial narrative, but that romance was not neccessarily indicative of romantic hero-worship of those Victorian soldiers. As Veracini argues, 'colonial narratives normally have a circular form, they correspond to an Odyssey consisting of an outward movement followed by interaction with exotic and colonised 'others' in foreign surroundings, and by a final return to the original locale. ${ }^{105}$ Veracini is of course referring to

\footnotetext{
96 Robley, c. 1919, FILD00056, JCBR, p. 10.

${ }^{97}$ Les W. Melvin, Horatio Gordon Robley: Soldier Artist in the Bay of Plenty 1864-1866, 2nd ed. (Tauranga: Tauranga Historical Society, 1990), p. 7; Leonard Bell, Colonial Constructs; European Images of Maori, 1841914, (Auckland: Auckland University Press, 1992), p. 99.

${ }^{98}$ Robley, 'Army Service from 1858', c. 1919, FILD00056, JCBR, p. 11; Melvin, p. 7.

99 Robley, ‘Army Service from 1858', c. 1919, FILD00056, JCBR, p. 13.

${ }^{100}$ Walker, 'Robley: Te Ropere 1840-1930', p. 42.

101 Ibid.

102 Fildes, ‘Major General H. Gordon Robley: Soldier and Artist’, 1921, Fildes MSS 1507, JCBR, p. 106.

103 Ibid.

${ }^{104}$ Robley, ‘Army Service from 1858', c. 1919, FILD00056, JCBR, pp. 14-37.

105 Veracini, ‘Telling the End of the Settler Colonial Story’, p. 205.
} 
Homer's Odyssey the mythical story of the trials and tribulations of Odysseus as he sailed across the Aegean to get home. There are certainly 'Odyssean' aspects of Robley's account, particularly when describing his route home via the Azores archipelago he adds a colourful account of 'nymphs bathing below the embrasures' of a fort at the water's edge.' ${ }^{106}$ Painting himself as being on a Homeric hero's journey, has particular relevance to the 1919 context with which the narrative was written down but the reality of being in the British Army in the nineteenth century differed greatly from the deified characters of the romantic past. At the time that Robley served in the $68^{\text {th }}$, the regimental system was still strongly hierarchical. ${ }^{107}$ When Robley joined in 1858 , to join a regiment officers had to purchase their military rank 'up to and including lieutenant colonel.' ${ }^{108}$ Robley had upon enlistment, purchased a 'ensignship' for $£ 450$, which while it was the lowest rank available, was a significant cost and suggests that Robley, following in his father's footsteps would have seen military service as a respectable career path, particularly if one could move up in the ranks of the regiment. ${ }^{109}$ However, due to a number of reasons, including the abolition of the rank purchasing system in 1871, along with the growing widespread need for British soldiers throughout the empire at any given time, by the time Robley retired in 1887 the British army had become as Richard Sinnreich explains: 'manned largely by its most disadvantaged members of British society and officered largely by its most advantaged, serving as a convenient depository for lower-class Britain's unemployed and as an outlet for its restless upper-class youth as much as an instrument of foreign policy. ${ }^{110}$ Having been promoted to lieutenant colonel in 1881 and to Major-General by the time of his retirement, ${ }^{111}$ Robley possibly had some semblance of a heroic image at the time of his journey's end but what he definitely did have was social standing. This is important for understanding the commanding and respected nature of his military rank as he explored new career ventures in London.

On his retirement, living in London, Robley took up his New Zealand interests. It was here where he began his ethnographic collecting of mokomokai from private collections, museums, and auction houses around Europe. Whenever Robley recounted the underpinnings of this ethnographic collecting, the narrative always began with the scene inside Gate Pā, when not only did Robley sketch the pā itself, but he had also recorded what he termed as the 'living face decoration' or moko, on the faces of dying combatants. ${ }^{112}$ According to Robley, he had brought these sketches back with him to London and was planning to write a book on 'the art of Maori tattooing' using their example, when, he

\footnotetext{
106 Ibid, p. 107.

${ }^{107}$ Richard Hart Sinnreich, 'An Army Apart', in Peter R. Mansoor (ed), The Culture of Military Organisations, (Cambridge: Cambridge University Press, p. 2019), pp. 159-160.

108 Ibid, p. 163.

${ }^{109}$ Ibid, p. 160; Walker, 'Robley: Te Ropere 1840-1930’, p. 3.

110 Ibid, p. 156.

${ }^{111}$ Walker, ‘Robley: Te Ropere 1840-1930’, p. 5.

112 Fildes, 'Major General H. Gordon Robley: Soldier and Artist', 1921, Fildes MSS 1507, JCBR. p. 60; Horatio Gordon Robley, 'History of a Collection, Maori Art', c. 1919, FILD00057, JCBR, p. 1.
} 
wrote, a chance had led to his 'supreme collecting.' ${ }^{\text {'13 }}$ This 'chance' came in 1893 when Robley noticed a mokomokai in the window of a phrenologist's office on Brompton Road in London. ${ }^{114}$ This would come to be the first of fourteen mokomokai that Robley purchased between 1893 and $1896 .{ }^{115}$ The next mokomokai in his collection came from the Meetham Sale in Plymouth, where he reportedly secured it against 'many bidders' and a further two would be purchased from the Wallace Collection in Edinburgh. ${ }^{116}$ Robley never mentioned the specific dates of these acquisitions, nor the prices he paid for them but he did suggest that they had cost him a good deal and that at times he had to 'oblige the seller with a loan.' ${ }^{117}$

It appeared both in his recollections and at the time that Robley was garnering a sense of notoriety in this process of collecting, and that he enjoyed playing into misinterpretations of the collection and his time in New Zealand. When recollecting the purchase of one of the Wallace Collection mokomokai, Robley mused at the surprise he had given the crowded room of auction attendees, when he greeted the mokomokai with a hongi, which he then explained to the crowd was 'an old rite of the most interesting savage people. ${ }^{118}$ When attending a ball in 1894, a year after he had started his collection, Robley recounted a conversation he had with the hostess:

But weren’t they cannibals? You never did, did you? Shouldn’t like to have it generally known, was my reply, but it wasn’t so bad. Oh how horrid! ${ }^{119}$

Robley clarified in his autobiographical notes that his response had been facetious. ${ }^{120}$ This was not however, the last time Robley would play up the savage tropes of Māori. His recollections of New Zealand included vivid narration 'the tribe who drank the blood of Rev. Volkner', including Kereopa the infamous 'eye-eater', also suggesting that he had become 'friends' with Taraia at a Tauranga 'war dance and canoe racing' event, 'who had cooked 2 native Christians in 1842. ${ }^{121}$ At the time of his later recollections Robley reported that he had run into an old comrade who had also served at Gate Pā, who had remembered him as the '68th officer always down on one knee sketching corpses'. ${ }^{122}$

Robley's playing up of the macabre was further evidenced by reports on him and his collection in British publications and photographs from the 1890s, some of which he had kept as ephemera and

\footnotetext{
${ }^{113}$ Robley, 'History of a Collection, Maori Art', FILD00057, JCBR, p. 1.

114 Ibid.

${ }^{115}$ Walker, 'Robley: Te Ropere 1840-1930’, p. 6.

116 Robley, 'History of a Collection, Maori Art', c. 1919, FILD00057, JCBR, p. 2.

${ }^{117}$ Ibid.

118 Ibid, pp. 2-3.

${ }^{119}$ Horatio Gordon Robley to Horace Fildes, 24 March 1921, 'Robley, H. G. (Major-General), 1921, Box 10, FILD0035c, JCBR.

${ }^{120}$ Horatio Gordon Robley, ‘Army Service from 1858’, c. 1919, FILD00056, JCBR, p. 73.

${ }^{121}$ Horace Fildes, 'Major General H. Gordon Robley: Soldier and Artist', Unpublished Manuscript, 1921, Fildes MSS 1507, JCBR, p. 93; Horatio Gordon Robley, 'Army Service from 1858’, c. 1919, FILD00056, JCBR, p. 13.

${ }^{122}$ Robley, 'History of a Collection, Maori Art', c. 1919, FILD00057, JCBR, p. 15.
} 
passed to Fildes, indicating a sense of enjoyment in the infamy. The mokomokai had been made accessible to Robley because of the burgeoning trade of the early part of the nineteenth century, but the common misconception about Robley's collection was that he had head-hunted the mokomokai himself while in New Zealand. ${ }^{123}$ In Robley's collection of ephemera was a newspaper article from Liverpool labelling him as a 'head-hunter', along with a satirical cartoon from a 1894 copy of Judy: The London Serio-Economic Journal portraying a scene where Robley knocks someone's head off their shoulders and steals it away. ${ }^{124} \mathrm{He}$ also included an image of himself observing two of the mokomokai with a little girl. On the back was a description written in Robley's handwriting where he talks about himself in third person: 'Photo taken by Mr. Stevens of a little neighbour of his looking at two of my specimen heads... The constant study of mokomokai has made H.G.R.'s face resemble an indifferent specimen.' ${ }^{125}$ Robley appeared to relish the 'spice' that these stories, regardless of their factuality, brought to his 'exotic' earlier life of a distant place and time.

Robley's collecting and analysing of mokomokai was characteristic of the 'object-based epistemology’ of scientific research at that time, and this afforded him some professional credibility. ${ }^{126}$ Mokomokai had featured as part of European understandings of Māori culture ever since naturalist Joseph Banks came into possession of a Māori mokomokai in $1770 .{ }^{127}$ By the mid nineteenth-century, particularly due to their increased appearance in the European market, mokomokai were synonymous with the term 'curio', to the Victorian sensibilities they were odd, bizarre and exotic. ${ }^{128}$ As Conal McCarthy argues, throughout the nineteenth century, the term ‘curio' became increasingly relegated to commercial sphere of collectors and 'curio dealers' whereby 'objects' like mokomokai were valued as fascinating marvels and little else. ${ }^{129}$ In contrast, museums were being influenced by the burgeoning natural history scholarship and development in human sciences that constructed the 'specimen' as an object that stood for all other objects of its type. ${ }^{130}$ By the time that Robley was collecting the mokomokai, the ethnographic value of the specimen object as 'concrete, objective and difficult to distort', with the ability to collapse the temporal and spatial distance between ethnographer and the culture in question, was widely accepted. ${ }^{131}$ The specimen object therefore held a crucial place in this new realm of human sciences, particularly given the undercurrent messaging of the disappearing

\footnotetext{
${ }^{123}$ Walker, 'Robley: Te Ropere 1840-1930’, pp. 47-49.

124 'A Famous Head-Hunter in Liverpool', 'Required to purchase, a dried tattooed New Zealand head - Colonel R. 7 St Albans Place, Haymarket', Judy: The London Serio-Economic Journal, 18 June 1894, 'Miscellaneous MSS notes and photographs concerning Major-General Robley’, Fildes MSS 1507, Folder 2, JCBR.

125 'Horatio Gordon Robley with two mokomokai', Box, Fildes MSS 1507, Folder 2, JCBR.

${ }^{126}$ Conal McCarthy, Exhibiting Māori, p. 21.

127 "Maybe they are a delicacy here", Joseph Banks, J.C. Beaglehole (ed.), The Endeavour Journal of Joseph Banks 1768-1771, Vol. I, (Sydney: Halstead Press, 1962), p. 457.

${ }^{128}$ McCarthy, Exhibiting Māori, p. 20.

129 Ibid.

130 Ibid.

${ }^{131}$ E. Pishief, 'Augustus Hamilton's 'scientific specimens or 'Maori Art': agency and the social life of things', Journal of the Royal Society of New Zealand, Vol. 47, No. 1, 2017, p. 133.
} 
indigene as a by-product of a colonising British world. ${ }^{132}$ Robley would later articulate the hopes of professional recognition in this work when suggesting that the transferal of the collection to a museum would elevate his name 'as a scientist in perpetuity. ${ }^{, 133}$ Not only had Robley obtained his first mokomokai from a phrenologist, by the time he had four 'specimen' mokomokai, he had been invited as part of a 'medical congress' to the home of collector Sir Jonathan Hutchison, where he would obtain a fifth specimen for his collection. ${ }^{134}$

As an extension of his interest in the art of moko, Robley's collection was not just for scientific purposes, it was an ethnological exploration of the art of moko and the mokomokai as traditional Māori art objects. By the time Robley started his collection in 1893, such an exploration echoed a growing ethnological art tradition in New Zealand to visualise the 'lost world' of traditional, prehistorical Māori art. ${ }^{135}$ The country that Robley had once termed the 'land of the Maori', the place of his soldiering travels had been becoming increasingly concerned with the Māori past that had predated its European settlement, harnessing its imagery for a sense of local self-fashioning as a part of the culture of Maoriland. ${ }^{136}$ By 1894 Robley began planning for a publication on Māori tattooing that would incorporate the sketches he had made in New Zealand and analyses of his ever-growing collection of mokomokai specimens. ${ }^{137}$ While mention of Robley was still infrequent in New Zealand at this time, by the beginning 1895 reports of his collection of 'Maori relics and curiosities' and his intention to publish an illustrated book on Māori tattooing began cropping up in New Zealand newspapers. ${ }^{138}$ In June 1896, Moko;or Maori Tattooing was published at Robley’s own expense by London publishers Chapman and Hall. ${ }^{139}$ The book was dedicated to those who had 'served against the warriors of New Zealand' standing as a reminder of the martial nature of Robley's inroad to Maoriland. ${ }^{140}$ It was clear that there had been at least some interest from Robley's antiquarian contemporaries in New Zealand in the lead up to the publication, when he included a letter of support in the preface from 'godfather of ethnological collecting', Sir George Grey. ${ }^{141}$ Grey’s letter to Robley typified the ‘spirit of lamentation' for the imminent loss of authentic Māori culture that was permeating the culture of Maoriland: ${ }^{142}$

Dear Sir, - I think your illustrations of Maori tattooing are interesting and valuable, as they give with great correctness some of the patterns of Maori tattooing; and the portraits are equally

\footnotetext{
132 McCarthy, Exhibiting Māori, p. 21.

133 Horatio Gordon Robley to Horace Fildes, 2 February 1921, FILD00035c, JCBR.

${ }^{134}$ Horatio Gordon Robley, 'Chapter on Maori Art Collecting and Book Thereon', c. 1919, FILD00057, JCBR, p. 3.

135 Blackley, Galleries of Maoriland, p. 43.

${ }^{136}$ Ibid, p. 45.

${ }^{137}$ Walker, 'Robley: Te Ropere 1840-1930’, p. 6.

138 ‘Anglo-Colonial Notes’, NZH, 22 January 1895, p. 6; ‘Anglo-Colonial Notes’, ODT, 24 January 1895, p. 4.

${ }^{139}$ Walker, 'Robley: Te Ropere 1840-1930', p. 6.

140 Robley, Moko; or Maori Tattooing, dedication.

${ }^{141}$ Blackley, Galleries of Maoriland, p. 2.

142 Ibid, p. 6.
} 
interesting as they give excellent illustrations of the art of "moko" which is rapidly passing away, and will soon be forgotten. ${ }^{143}$

The preface also included a letter from English politician and scientist John Lubbock, who gave a frank interpretation of the fate of the Māori subjects of Robley's study:

'Dear Sir, - I beg to acknowledge the receipt of your letter, and shall be happy to see your book on New Zealand tattooing. It is most important to preserve all evidence of a life which is rapidly disappearing.' 144

Lubbock's statement seemed to strike to the heart of what Grey, and many other Pākehā ethnologists operating in Maoriland, were inferring in their melancholic nostalgia for a prehistorical Māori heyday.

Robley himself outlined his purpose for the publication in the opening of the preface to 'present a series of illustrations of the art of moko or tattooing, as practised by the Maoris. It is fast vanishing, and a record of it by one who has studied the subject for many years may be worth publication., ${ }^{145}$ Robley separated the publication into two parts. The first focused on moko: isolating and analysing the 'grotesque' and 'arabesque' ornamental aspects of moko design to prove the 'artistic faculty' of the tohunga tā moko. ${ }^{146}$ According to Walker, Robley's appreciation of moko was 'the correlation between the physical properties of the practice of moko and the quality of its designs. ${ }^{147}$ In the second he focused on the history of mokomokai: continuing to 'illustrate the art of moko and its interest as design', but focusing on the trade and dissemination of mokomokai in the early nineteenth-century as a major detractor of their authenticity as examples of traditional Māori culture. ${ }^{148}$ In the chapter entitled 'The Decadence of Moko' Robley reminded his readership that with the art of moko inevitably set to 'vanish', mokomokai would be key to the study of the authentic art. ${ }^{149}$ Despite the apparent enjoyment of the notoriety he had garnered in collecting the mokomokai, when discussing the 'principal object of the custom' he described it as not one of 'mere brutality' but one of distinction, 'to keep alive the memory of the dead. ${ }^{150}$

Robley drew on a variety of New Zealand ethnological sources, including Edward Tregear. Eleven years earlier Tregear had published The Aryan Maori, a work that James Belich has argued as

\footnotetext{
${ }^{143}$ George Grey to Horatio Gordon Robley, 3 August 1894, Moko; or Maori Tattooing, (London: Chapman and Hall, 1894), p. xi.

${ }^{144}$ John Lubbock to Horatio Gordon Robley, 1 December 1894, Moko; or Maori Tattooing, p. xi.

${ }^{145}$ Robley, Moko; or Maori Tattooing, p. ix.

${ }^{146}$ Ibid, pp. 64-97.

${ }^{147}$ Walker, 'Robley: Te Ropere 1840-1930', p. 75.

${ }^{148}$ Robley, Moko; or Maori Tattooing, p. 129.

${ }^{149}$ Ibid, p. 122.

${ }^{150}$ Ibid, pp. 132-133.
} 
an important assimilatory idea in the cultural programme of settler nationalism in New Zealand. ${ }^{151}$ Robley's ethnic theorising in Moko; or Maori Tattooing tended towards Egyptian or Thracian comparisons of moko rather than Tregear's Aryan, Indian origin theory. ${ }^{152}$ While these comparisons themselves had a similar shared ancestry connotation, Robley would later incorporate the ideas into one long theory of an eastward migration of Māori from the Levant, through India and South Asia to New Zealand. ${ }^{153}$ The publication was thus exemplary of the preservatory language of Maoriland, and even dabbled in some of the defining racial theories of the period.

After it was published, Moko; or Maori Tattooing appeared to put Robley on the map. Six months after its publication in 1896, Robley was invited to speak on his collection at the Royal Anthropological Institute in London, bringing the collection itself in tow. ${ }^{154}$ In a letter to fellow British military veteran G.H. Tate-Stoate shortly after the publication of Moko, Robley reported that not only had he received a nice letter from the former president of the Cape Colony, Cecil Rhodes, after he obtained a copy on a trip back to England, but that Queen Victoria herself had also read the publication. ${ }^{155}$ More pertinent however was the degree to which it brought him to the attention of a wider New Zealand audience. By the time Moko was published in 1896, Robley and the publication itself was reported in a number of New Zealand newspaper outlets across the colony. ${ }^{156}$ The book had more immediate impact in circles of 'diasporic Pākehā' in London at the time. ${ }^{157}$ It is unclear how Robley came to meet the new agent-general at New Zealand House, William Pember Reeves, but in July 1897 he was invited to present his collection at a dinner put on 'by the meat trade' to honour Premier Richard Seddon who had been in London to attend Queen Victoria’s Diamond Jubilee. ${ }^{158}$ Recounted in his usual fashion, Robley mused at the way his collection, amongst the display of exported produce shocked those attending. ${ }^{159}$ When Pember Reeves published his own short history of New Zealand in 1898, The Long White Cloud - Ao Tea Roa, he listed Robley along with the likes of Augustus Hamilton, Sir Walter Buller, Percy Smith and Edward Tregear in his note of acknowledgement and citation of work 'on the Maoris.' ${ }^{160}$ Polynesian Society member John C. Adams, would later describe

\footnotetext{
151 James Belich 'Myth, Race and Identity in New Zealand', NZJH, Vol. 31, No. 1997, as cited in Tony Ballantyne, Webs of Empire: Locating New Zealand's Colonial Past, (Wellington: Bridget Williams Books, 2012), p. 28.

152 Robley, Moko; or Maori Tattooing, pp. 3, 144, 157.

${ }^{153}$ Horatio Gordon Robley, ‘A History of the Maori Tiki’, c. 1920, ‘Article by Robley’, MS-Papers-1387-14, ATL.

${ }^{154}$ Walker, 'Robley: Te Ropere 1840-1930’, p. 6.

155 Horatio Gordon Robley to G.H. Tate-Stoate, 14 January c. 1897-1901, 'Horatio Gordon Robley - Outward Correspondence', MS-Papers-1387-13, ATL.

156 ‘Anglo-Colonial Notes, New Zealand Herald (NZH), 22 January 1895, p. 6; ‘Current Topics’, OW, 26 November 1896, p. 3.

157 Blackley, Galleries of Maoriland, p. 206.

158 Ibid, p. 207.

${ }^{159}$ Horatio Gordon Robley, ‘Army Service from 1858’, c. 1919, FILD00056, JCBR, p. 67.

${ }^{160}$ William Pember Reeves, The Long White Cloud - Ao Tea Roa, (London: Horace Marshall and Son, 1898), pp. ix, 417.
} 
Pember Reeves' 1898 portrayal of Robley's work on moko as 'eulogistic.' ${ }^{161}$ In the preface to his history Pember Reeves asserted:

I believe that there amongst the people of the Mother Country a minority, now ceasing to be small, which takes a quickening interest in the Colonies... they have come to realise that those newcomers into the circle of civilised communities, the daughter nations of Britain, are not unworthy of English study and English pride. ${ }^{162}$

In that same year, both Pember Reeves and Robley were amongst twenty or so 'New Zealanders' who gathered for a banquet at the Café Roche in Soho. As Blackley writes, the event included both those born in New Zealand as well as some of those like Robley, who had earned a sense of 'membership' to the colony from spending a portion of their lives there. ${ }^{163}$ By this time, Robley was regularly reported on back in New Zealand in the 'anglo-colonial' or 'personal' notes section of local newspapers, wherein a London correspondent would keep those in the colony up to date on the daily events of people of interest back in the metropole. ${ }^{164}$ When news of the Anglo-South African War swept across the British Empire and its colonies in 1899 and Seddon had offered up a New Zealand contingent to support the British forces, Robley took the opportunity of this pivotal moment to display both his work on moko and his strengthened affiliation with New Zealand. In June 1900, having had his collection returned to him from Liverpool where it had been on display, ${ }^{165}$ Robley sent a depiction of the leader of the Transvaal Paul Kruger to The Graphic sporting a tā moko made to look like the Māori King Tāwhiao [see fig. 1]. ${ }^{166}$ The sketch was rich with meaning for both those living in the metropole and those in New Zealand. The Anglo-South African War was the most large-scale, industrialised effort the British world had seen, and as Dion Georgiou argues, the British discourse was often centred on the 'dehumanising of a white enemy previously reserved for non-white natives.' ${ }^{167}$ Robley's image of Kruger seemed to encapsulate this notion, but it also appears to reference the prominent place that Tāwhiao held in the imagination of Maoriland. Particularly because Tāwhiao had travelled to Auckland in 1882 after the opening of the King Country and to London in 1884 where he was constantly stalked by metropolitan journalists. ${ }^{168}$ The war had, in 1900, inspired a flurry of carnivals and events around London in order to raise funds for families of deceased combatants. ${ }^{169}$ One of these events was London's 'National Bazaar' held at Kensington Palace in July 1900, where those representing the different

\footnotetext{
${ }^{161}$ John C. Adams to 'the president and members of the Council of the Polynesian Society', 10 November 1925, 'Polynesian Society Records - Correspondence', 80-115-04B/01, ATL.

162 Pember Reeves, p. v.

163 Blackley, Galleries of Maoriland, p. 207.

164 ‘Anglo-Colonial Notes', ODT, 22 March 1898, p. 2; 'Personal Notes from London’, AS, 12 February 1900, p. 3.

165 Walker, ‘Robley: Te Ropere 1840-1930’, p. 6.

166 'Personal Notes from London', AS, 6 June 1900, p. 2.

${ }^{167}$ Dion Georgiou, 'Restaging Mafeking in Muswell Hill: Performing Patriotism and Charitability, Historical Research, Vol. 91, No. 254, 2018, p. 747.

168 Blackley, Galleries of Maoriland, p. 215.

169 Georgiou, p. 744.
} 
colonies within the empire put up stalls to sell themed goods. ${ }^{170}$ Robley, who along with a few of the diplomats' wives, was involved in setting up the New Zealand stall and had contributed a 'large portrait' version of his Kruger-Tāwhiao sketch to be sold alongside 'Maori dolls and greenstone ornaments'. ${ }^{171}$ It seems that by this time Robley would have had every reason to feel confident in his reception in New Zealand. Robley had become well acquainted and on good terms with agent general Pember Reeves, those within his circle of prominent New Zealanders and was also in regular contact with the London correspondents of those New Zealand newspapers. ${ }^{172}$ In 'conversation' with one such correspondent, Robley reported in April 1901 that with one more recent addition, his collection of mokomokai then stood at 32. ${ }^{173}$ Robley's full collection Maori curios, that included pounamu, carvings and weaponry was not just exemplary of those ethnological art collections of his contemporaries back in New Zealand but was set apart, at least in Robley's view by the 32 mokomokai. The next step for Robley would be

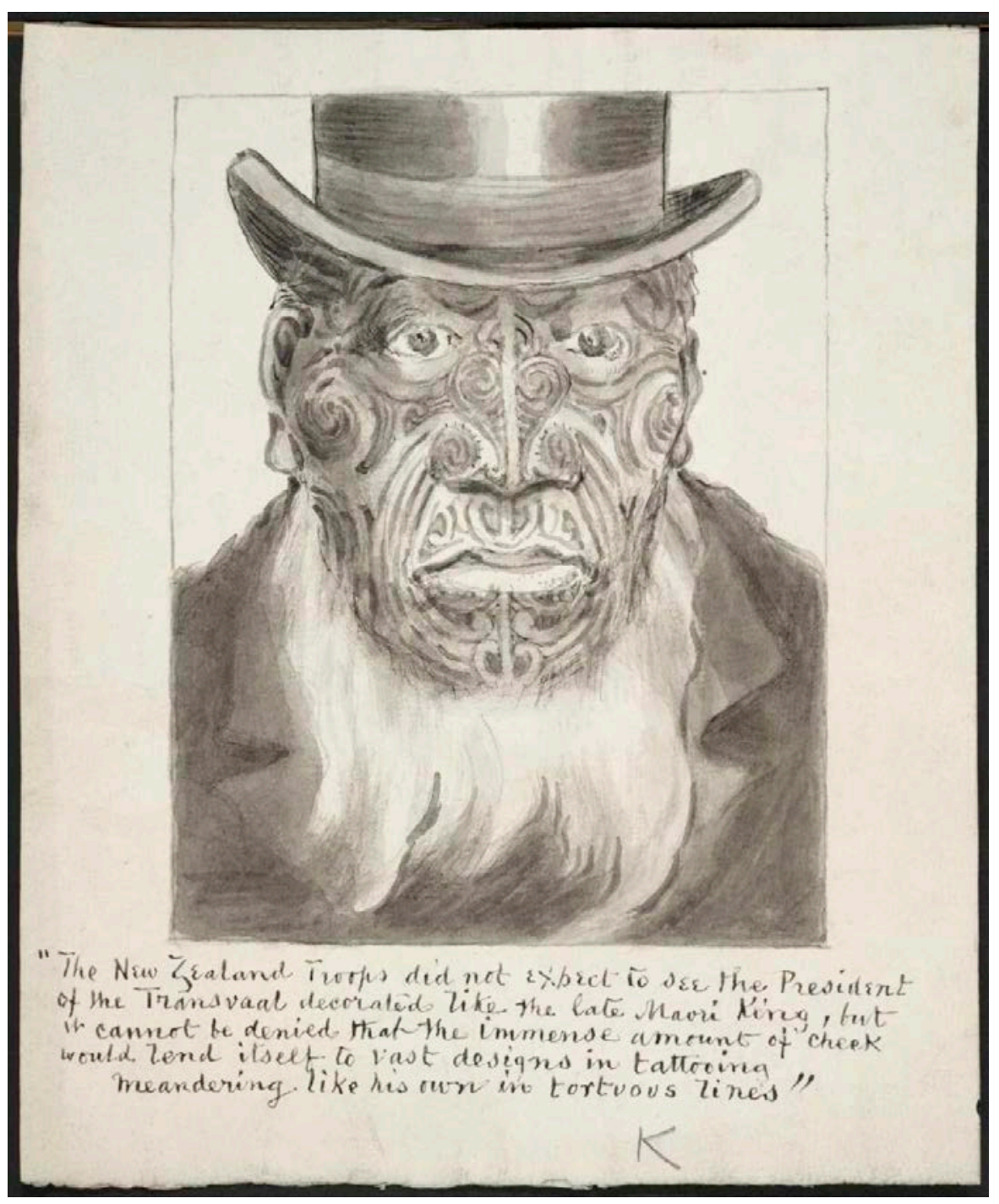

Fig 1. - Horatio Gordon Robley, 'Paul Kruger, president of the Transvaal, drawn with Māori facial tattoo', c. 1900, A-080-025, Alexander Turnbull Library, Wellington.

170 'News of the War: The Great London Bazaar', Evening Post (EP), 7 July 1900, p. 5.

171 Ibid.

172 ‘Anglo-Colonial Notes’, ODT, 22 April 1901, p. 3.

173 Ibid. 
to have them officially recognised not just by those engaged in Maoriland's culture of display but by those governing its policies.

Turning now to the youngest of the three history-makers, James Cowan's colonial experience shares many of its contextual concerns with those of Statham and Robley, but as the only 'native-born Pakeha ${ }^{174}$ his experience adds unique considerations for settler and indigenous relationships. This next section looks at the childhood of Cowan on the embattled aukati border in the Waikato and how this translated into his professional life as a journalist in Auckland. Like Robley, many of the accounts of Cowan's early life were dictated by Cowan himself in his publications from the New Zealand Wars in 1922 and onwards. Unlike Robley, who wrote a full autobiographical chronology of his life and work, Cowan's recollections often show up as launching points for his later historical retellings of interactions between colonial peoples and the land and its inhabitants. Because his recollections reference the contexts of his childhood, they are often presented through a nostalgic hue - distant, mythical but also central to Cowan's perception of his life and professional credibility. They provide important details of Cowan's trajectory as it relates to proximity and place.

Seven years after the Statham family had arrived in Otago and less than five years after Robley had been and gone from the Bay of Plenty, Irish immigrant William Andrew Cowan and his wife Elizabeth Qualtrough welcomed a son who they named James Cowan. He was born on 14 April, in 1870 at the Qualtrough family homestead in Pakuranga, Auckland. ${ }^{175}$ According to David Colquhoun, William Cowan had emigrated from Ireland to fight in the battles of the Waikato invasion, though Cowan himself rarely ever made mention of his father's early occupation. ${ }^{176}$ Nevertheless, it was likely because of his father's soldiering that Cowan and his family moved to the newly established military settler farmland near Kihikihi in the Waikato when he was just six months old. ${ }^{177}$ As Vincent O’Malley has discussed, the 'planting' of military settlers on land that had been confiscated from Waikato-Tainui was a 'key rationale of Raupatu. ${ }^{\text {, }}{ }^{178} \mathrm{O}$ 'Malley argues that the view of the colonial government was that settling soldiers (and their families) on confiscated land, would serve as a 'protective buffer' for any future uprisings by Kīngitanga forces. ${ }^{179}$ By the time the Cowan family had moved onto the land 1870 , this settlement scheme had largely been considered a failure for the initial struggle to cultivate the land and sustain themselves, which had overwhelmed many of the original 'settlers. ${ }^{\text {'180 }}$ Many sold their lands quickly, some heading to the Otago goldfields that had afforded Statham's town of Dunedin with such

\footnotetext{
174 James Cowan, The Maori: Yesterday and To-Day, (Christchurch: Whitcombe \& Tombs, 1930), p. 148.

175 Colquhoun, 'Cowan, James', DNZB, Te Ara, 1996, updated 2012;

https://teara.govt.nz/en/biographies/3c36/cowan-james; accessed 27 April 2021.

176 Ibid.

177 Cooper, ‘No Ōrākau: Past and people in James Cowan’s places’, p. 72.

178 Vincent O’Malley, The Great War for New Zealand; Waikato 1800-2000, p. 499.

179 Ibid, p. 453.

180 Ibid, p. 468.
} 
wealth and prosperity. ${ }^{181}$ By 1868, 58 per cent of those initial military settlers had left. ${ }^{182}$ According to Cowan, who wrote particularly vividly about the scenes of his childhood in his 1940 Settlers and Pioneers, the family had been sold their new property by one of those departing militia officers. ${ }^{183}$ Not only was the property contested for its place on confiscated land, it also sat upon the site of the battle of Ōrākau, the last of the Kīngitanga's defensive battles against the Waikato Invasion. ${ }^{184}$ As Cowan wrote at the top of an account of Ōrākau in 1935, this childhood proximity to the site of Ōrākau was formative to his sense of self:

That sacred spot is in my earliest recollections of childhood, for my father's farm included part of the battlefield, the pa site was close to our homestead, and the traditions and place-magic of Orakau became part of my very being. ${ }^{185}$

Such a statement, expressed a preoccupation with the land and territorial belonging, which Patrick Wolfe argues as the 'specific, irreducable element' of settler colonial rhetoric. ${ }^{186}$

The Cowan family farm sat on the soil of conflicts past, but it was its adjacency to the aukati border of the King Country that brought the ongoing impact of that conflict into sharp relief for Cowan. In the wake of the government force's conclusive attack at Ōrākau, King Tāwhiao and some of his people retreated south into Ngāti Maniapoto lands into what would become the autonomous region known as Te Rohe Pōtae or the King Country. ${ }^{187}$ The aukati or boundary between Ngāti Maniapoto land and the newly confiscated settler farms was marked in the Kihikihi area by the Puniu River just south of the Cowan family property. ${ }^{188}$ But for Cowan as a child, this distinct separation was marked more by the visual contrasts of the landscape. As Michael Belgrave and Annabel Cooper illustrate in their analyses of Cowan, the 'small easily exhausted plots' of military settlements sat in constant juxtaposition with the 'semi-wild abundance' of the land beyond the border. ${ }^{189}$ That land had once been the site of what Cowan described in 1922 as the 'golden age' of abundant horticultural and agricultural production by Waikato and Ngāti Maniapoto groups. ${ }^{190}$ As Hazel Petrie has explored in Chiefs of Industry, what was once a thriving industry, at one time sustaining early Auckland settlement, had been forced to draw labour away from food production in the 1860s in order to protect lands as government

\footnotetext{
${ }^{181}$ Ibid, p. 465; Olssen, A History of Otago, p. 56.

182 Ibid.

183 James Cowan, Settlers and Pioneers, (Wellington; Department of Internal Affairs, 1940), p. 44.

${ }^{184}$ Cooper, ‘No Ōrākau: Past and people in James Cowan’s places’, p. 63.

185 James Cowan, Hero Stories of New Zealand, (Wellington: Harry H. Tombs Ltd, 1935), p. 99.

${ }^{186}$ Wolfe, 'Settler Colonialism and the Elimination of the Native', p. 387.

${ }^{187}$ Kerryn Pollock, 'King Country region - Te Rohe Pōtae', Te Ara; http://www.TeAra.govt.nz/en/king-countryregion/page-6; accessed 28 June 2021.

188 Ibid.

${ }^{189}$ Michael Belgrave, 'James Cowan: Autobiographical Historian and Traveller in Time’, JNZS, No. 19, 2015, p. 53.

190 James Cowan, The Old Frontier: Te Awamutu, The Story of the Waipa Valley, (Te Awamutu: Waipa Post and Publishing Company, 1922), p. 18.
} 
forces moved in from the north. ${ }^{191}$ In Settlers and Pioneers, Cowan described the landscape with his characteristic nostalgic hue:

The first home I knew, the first trees and flowers, were on the soil that had less than ten years before been a battlefield... The farm lay with a gentle tilt to the north. Wheat was much grown and gave large yields. Memory lingers on the many peach groves and cherry groves, Maori planted, laden with the largest and sweetest fruit ever grown. ${ }^{192}$

Those memories of the landscape, often recounted as Cooper argues with 'harmonious calm in the likeness of rural England' is crucial to understanding Cowan's later ambivalent treatment of Māori within a rhetoric of modernity and progress. ${ }^{193}$

The aukati remained a stark testimony to the area's recent contestation right up until the 1882 proclamation of amnesty for those, including Te Kooti, who had sought refuge behind the border and the King Country was gradually 'opened' from the year after. ${ }^{194}$ As Belgrave highlights, the first thirteen years of Cowan's life was still a time of regular drills and the expectation to be ready to defend their frontier, some isolated events of violence on the aukati only exacerbated this ongoing sense of alarm. ${ }^{195}$ But this tension did not dictate all Māori-settler relationships during this period and for Cowan as a child this was particularly true, at least in the way he presented it in later years. Cowan's childhood 'fossicking around the Ôrākau trenches' and in and around the old groves of trees was spent with both Pākehā and Māori his own age, one of which, Te Huia Raureti would later become a key informant for Cowan's research. ${ }^{196}$ Furthermore, the Māori defenders of Ōrākau and once the 'bogeymen' of the settler imagination Rewi Maniapoto and Wahanui Huatere had been a familiar sight in Cowan's youth and had even come to be 'calming mediators' between settlers and Kīngitanga. ${ }^{197}$ It has also been suggested by Belgrave that an eleven year old Cowan was most probably present to witness King Tāwhiao and 76 supporters mark peace (but not submission) with William Mair at Alexandra in July 1881. ${ }^{198}$ It would seem that Cowan's colonial experience, distinct from that of Statham and Robley's, was defined by its dichotomy of being both proximate to significant moments of conflict as well as being marked by the innocence of a childhood of peaceful coexistense.

In terms of the Cowan family's financial position, it appears that Cowan's childhood and teenage years differed greatly from those of Robley and Statham. The Cowan family farm seemed to

\footnotetext{
${ }^{191}$ Hazel Petrie, Chiefs of Industry, (Auckland: Auckland University Press, 2006), pp. 140, 269.

192 Cowan, Settlers and Pioneers, p. 44.

193 Cooper, 'No Ōrākau: Past and people in James Cowan’s places’, p. 68; Belgrave, p. 51.

194 Tui Adams, Ngahinaturae Te Uira, Ann Parsonson, 'Behold a Kite that Flies Towards You: the Kiingtanga and the 'Opening' of the King Country’, NZJH, Vol. 31, No. 1, 1997, p. 101.

195 Belgrave, p. 54.

${ }^{196}$ Ibid, p. 51; Cooper, ‘Nō Ōrākau: Past and people in James Cowan’s places’, p. 69.

197 Ibid.

198 Ibid.
} 
maintain them while Cowan was in Kihikihi, and he reflected on the 'simple' nature of their livelihood in Settlers and Pioneers, calling it 'comfortable and happy, however primitive in some ways. ${ }^{199}$ Farm production in New Zealand had notably increased during the period of Cowan's youth, but in his own account of life on the farm he asserted that it was something more akin to the pioneering days, a fullyself-contained lifestyle and he later lamented the move away to more industrialised production. ${ }^{200}$ Cowan attended the public school in Kihikihi, and by the time he had turned sixteen he had gained fluency in te reo in his milieu. ${ }^{201}$ In December 1886, it was reported in the New Zealand Herald that Cowan had sat and passed his civil service examination. ${ }^{202}$ On this basis, historian Chris Hilliard notes, he was offered a cadetship at the Native Department in Wellington which he ultimately turned down partly because his mother thought he was too young to move to the city. ${ }^{203}$ According to Colquhoun, Cowan first tried his hand at journalistic writing a year after, writing two articles, presumably on local topics for the New Zealand Herald. ${ }^{204}$ By 1888, he had been offered a position as a junior reporter for the Auckland Star, and had moved to Auckland to take up the job. ${ }^{205}$ It appears that the timing of this appointment was opportune, as the Auckland Star in July of that year carried a notice that Cowan's father, William had applied for bankruptcy. ${ }^{206}$ The report of his surrender of the property near Ōrākau cited that 'his losses were chiefly caused through dealings in native land' and that he had 'held on longer than he should have done with the hope that things would mend. ${ }^{207}$ These circumstances indicate that not was all amicable as Cowan's later nostalgic renderings of his frontier childhood suggested. There is nothing to suggest that there was any relationship between this event and Cowan's appointment, what it does demonstrate however was the degree to which the role at the Auckland Star was not just an opportunity, but perhaps a necessity, for Cowan to earn his own living. But as the next section looking at Cowan's journalism career attests, junior reporting was not necessarily an escape from the toil of a farming youth.

To be a junior journalist in Auckland in 1888 was not a privileged nor a well-remunerated position but it did hold the possibility for steep incline to more influential editor positions as well as great potential for building reputation amongst a readership. As Margaret Rees-Jones illustrates the position of junior reporter was at the very bottom of the editorial ladder. Akin to 'footsoldiers' their work collecting news from the regions often involved challenging conditions and was much more

\footnotetext{
${ }^{199}$ Cowan, Settlers and Pioneers, p. 45.

${ }^{200}$ Ibid, p. 48; David Hastings, Extra! Extra!: How People Made the News, (Auckland: Auckland University Press, 2013), p. 175.

${ }^{201}$ Colquhoun, 'Cowan, James', DNZB, Te Ara.

202 'Civil service examinations', NZH, 27 December 1886, p. 6.

203 Hilliard, 'Stories of an Era Not Yet So Very Remote’, p. 30.

${ }^{204}$ Colquhoun, 'Cowan, James', DNZB, Te Ara.

205 Hilliard, 'Stories of an Era Not Yet So Very Remote', p. 30.

${ }^{206}$ AS, 21 July 1888, p. 8.

${ }^{207}$ Ibid.
} 
physical than the image of journalism perpetuates. ${ }^{208}$ It was not unusual for these reporters, particularly those in more provincial towns, to ride horseback to some of the more difficult destinations to get to, and this mode of transport was often featured in Cowan's recounts of some his backblock journeys. ${ }^{209}$ The demands of this type of reporting would have particularly applied to Cowan who became the Auckland Star's resident expert in 'Māori affairs' and specialist in the apparently related genre of travel journalism. ${ }^{210}$ It is hard to definitively say what Cowan would have been paid at this early stage, particularly because the period with which he was beginning his career was one where 'fortunes had a habit of fluctuating. ${ }^{211}$ The example of Allan Stanley Muir, another amateur reporter, provides clues. Muir started at the New Zealand Herald in 1911 on $£ 1$ a week and reported working fourteen hour days. ${ }^{212} \mathrm{~A}$ wage like this would have been enough to get by but it would have hardly compensated for the intensity of the labour nor the number of hours worked. However, there was a clear path of opportunity in the journalism world if that was where a young reporter wanted to stay. As Rees-Jones argues, junior reporters had the potential to rise to general or senior reporting or even to sub-editing or board positions and it was often that they did elevate their role in their later years. ${ }^{213}$ The top editor position was harder to obtain, particular in the case of the Auckland Star during Cowan's time as Thomson Leys, who won the position after sub-editing for four years, held on to the top position for another forty-five years. ${ }^{214}$ Leys, a one-time political candidate, held a variety of powerful affiliations during the time that Cowan was at the Star. He was in close communication with politicians and diplomats such as William Pember Reeves, Richard Seddon and John Ballance. ${ }^{215}$

Regardless of journalist's aspirations, their reporting roles gave them an opportunity to build a reputation across the ever-increasing readership from the 1870s. By the time that Cowan had entered the busy scene of Auckland print media the two big publications of the morning New Zealand Herald and evening Auckland Star had been going head to head for recognition as the top publication in New Zealand. ${ }^{216}$ However it was the Star that time and time again came out on top of circulation and readership during the 1890s, with figures from 1898 reporting that over 15,000 copies a day were being circulated to Auckland's total provincial population of nearly 180,000. ${ }^{217}$ There was a certain mutual relationship between these daily newspapers and their communities of readers. As the only form of

\footnotetext{
208 Margaret Reese-Jones, Printer's Progress: A New Zealand Newspaper Story 1840-2014, (Gisborne: Gisborne Herald Co. Ltd., 2015), p. 150.

${ }^{209}$ Ibid; For example see James Cowan, Tales of the Maori Bush, (Christchurch: Whitcombe and Tombs, 1934), p. 15.

${ }^{210}$ Hillard, 'Stories of an Era not yet so very remote', p. 30; Cooper, 'No Ōrākau: Past and people in James

Cowan's places', p. 64.

${ }^{211}$ Rees-Jones, p. 149.

212 Ibid, pp. 149-150.

213 Ibid, pp. 149, 158.

${ }^{214}$ Hastings pp. 134-135.

${ }^{215}$ Ibid, p. 184.

${ }^{216}$ Ibid, p. 144.

${ }^{217}$ Ian F. Grant, Lasting Impressions: The Story of New Zealand's Newspapers 1840-1920, (Masterton: Fraser Books, 2018), p. 509.
} 
information about public concerns, readers needed to be able to trust these publications and editors like Leys worked to position them not just as 'gatherers and sellers of news and advertising' but also as advocates for the interests within those communities. ${ }^{218}$ Part of this sense of communal advocacy of newspaper journalism was that while there was some room to push political agendas of the different publications, (the Star for example was known for its unwavering support of the Seddon government), when it came to the news they 'had to give readers what they wanted. ${ }^{219}$ It is in this realm of newspaper considerations for circulation and popularity amongst a predominantly urban readership that Cowan was gathering accounts from Māori informants and publishing on Māori topics. As a 'back-blocks cultural broker' Cowan, as Hilliard demonstrates, like many of his contemporaries was careful to not go so far as to publish those Māori accounts in their original reo, not even in a bilingual format. ${ }^{220}$

What is significant about this opportunity for reporters to build reputable connections with readers, however, is that it happened at a time when journalism was still anonymous or written under pseudonyms. ${ }^{221}$ This is likely why it is difficult to trace specific reports in Cowan's early journalism career, or as Colquhoun points out, much information about his personal life during the 1890s. ${ }^{222}$ The period when Cowan was at the Star, did see significant some significant events relating to Māori and colonial relations that it is most likely that Cowan reported on, such as the death of King Tāwhiao and Rewi Maniāpoto in 1894 or, as Blackley suggests, the visit Tāwhiao's successor Mahuta made to Auckland in $1901 .{ }^{223}$ Aside from Māori affairs, Cowan was also a part of the Star's literary staff and in 1893 was given the opportunity to interview prominent writer Robert Louis Stevenson, when Stevenson visited Auckland from Samoa. ${ }^{224}$ In 1894 Cowan married Eunice Lilia Nicholas, the daughter of Edwin Owen of Auckland and Lililia Nicholas of Niue. ${ }^{225}$ Colquhoun also highlights that Cowan took an interest in the naval activity of Auckland's port, as well as yachting and rowing during this time in Auckland. ${ }^{226}$ In 1899 Cowan was sent aboard one of those ships by the Star, presumably because of his reputation for reporting on indigenous matters, to sail to Samoa to report on the second civil war and the partition of Western Samoa into a German colony. ${ }^{227}$ When he recounted his trip much later in 1939,

\footnotetext{
${ }^{218}$ Hastings, p. 136.

${ }^{219}$ Ibid, pp. 187, 218.

${ }^{220}$ Ibid, p. 103; Hilliard, 'Stories of an Era not yet so very remote’, p. 30; Cooper, 'No Ōrākau: Past and people

in James Cowan’s places’, p. 30; Paul Meredith, p. 9.

${ }^{221}$ Hastings, p. 174.

${ }^{222}$ Colquhoun, 'Cowan, James', DNZB, Te Ara.

${ }^{223}$ Roger Blackley, 'The Plutarch of Maoriland: James Cowan and Pictures of Old New Zealand', JNZS, Vol. 19, 2015, p. 111.

${ }^{224}$ Colquhoun, 'Cowan, James', DNZB, Te Ara.

225 'The Social Sphere', Observer, 11 August 1894, p. 8.

${ }^{226}$ Colquhoun, 'Cowan, James', DNZB, Te Ara.

227 James Cowan, 'Memories of Old Samoa', New Zealand Railways Magazine, Vol. 14, Iss. 1, 1939;

http://nzetc.victoria.ac.nz/tm/scholarly/tei-Gov14_01Rail-t1-body-d6.html; accessed 29 June 2021.
} 
Cowan 'disentangled' himself from the politics of the situation and instead discussed the Samoan traditions he experienced. ${ }^{228}$

He remained close to Māori subjects which at some point, probably in 1901, Blackley has surmised, caught the attention of Henry Partridge, a prolific local art collector in Auckland who had that year opened a gallery of Māori portraits by Gottfried Lindauer. ${ }^{229}$ The gallery on Queen St quickly became what Blackley has described as a 'Mecca for Māori, tourists and locals alike.' ${ }^{230}$ With the experience and meaning of viewing the images Māori, many of whom were deceased, being vastly different for those Māori and Pākehā visitors by 1901. Cowan, now well known for his proximity to the Māori world, and his literary skills developed by his rigorous work at the Auckland Star, was hired by Partridge to write the accompanying biographies of those Rangatira depicted in Lindauer's portraits. ${ }^{231}$ The catalogue, entitled Maori Biographies, Sketches of Old New Zealand, was exemplary of the 'salvage' mentalities of Maoriland ethnographical art that Robley was also espousing from London. In the introduction Cowan writes:

it is the hope of the compiler that this collection of lives of Maori celebrities will excite the attention of the public and heighten the interest in these typical members of the New Zealand native race. Mr. H.E. Partridge's collection of Maori portraits is unrivalled in the world, and it gives the visitor from abroad as well as the colonist an excellent idea of the native people of the old school, the dignified rangatiras and warrior-chiefs, who have now nearly all passed away to the Reinga, the Underworld of death. Another very few years will see the last of the tattooed old chiefs who are the surviving types of a splendid savage race. ${ }^{232}$

There is a sense in this passage that Cowan was mourning a loss. Not for the loss of Māori people as such, that would be a claim that would contradict the prolific nature of Māori visitation to the gallery itself. ${ }^{233}$ Instead it was a loss of a type of Māori figure that was becoming inextricable from Cowan's memory of his youth on the Waikato frontier. Rewi and Tāwhiao, having died seven years earlier perhaps embodied this concern of Cowan's. Installing fear, awe and respect in a young Cowan, particularly in the aukati context with which he came to know them, Rewi and Tāwhiao epitomised a Māori world that Cowan, it seemed, saw as preferable, and the fact that this mournful loss was articulated in a gallery handbook, within the context of display was significant.

\footnotetext{
${ }^{228}$ Ibid.

${ }^{229}$ Blackley, 'The Plutarch of Maoriland', p. 111.

${ }^{230}$ Blackley, Galleries of Maoriland, p. 18.

${ }^{231}$ Blackley, 'The Plutarch of Maoriland', p. 111

${ }^{232}$ James Cowan, Maori Biographies, Sketches of Old New Zealand, (Auckland: Brett Publishing Co., 1901), p. 2. ${ }^{233}$ Blackley, Galleries of Maoriland, p. 18.
} 


\section{Chapter Two \\ Maoriland in the shadow of a Matriarch: Cultural Locality and Imperial Belonging in the New Century 1901-1914}

By 1901, Statham had moved from Dunedin and settled in Auckland, Robley, still in London had published Moko; or Maori Tattooing establishing himself as an author and an expert on Māori topics and Cowan had just published his gallery handbook of biographies for Henry Partridge in Auckland. The turn of the century thus marked significant moments of change for each of the three history-makers but as this present discussion demonstrates, their nineteenth-century colonial experiences would continue to shape their respective activities within a period marked by further societal and technological change. 1901 had also seen the death of Britain and the empire's longest standing monarch, Queen Victoria, and the decision by the Seddon government to not take part in Australian federation across the Tasman. The Anglo-South African War that had touched upon the lives of Statham and Robley in particular, ended in the following year. The development of more efficient travel options, new capacities for photography within print media and New Zealand's entry into the 1901 international penny post agreement all indicated a new dynamic of intercultural and interpersonal relationships between those in New Zealand and those in the metropole. ${ }^{1}$ The years that followed, as Jane Stafford and Mark Williams argue, signalled a merging of Maoriland with a mood of imperial enthusiasm. $^{2}$ Looking at the period from 1901 to the beginnings of the Great War in 1914, this chapter charts the way in which the tensions between the sense of a cultural locality and belonging as a part of the wider British empire is reflected in the history-makers’ work. It also charts the variety of concerns and opportunities that prompted each of these three to address more urgently and actively the need to record, narrate and create New Zealand's history. As their paths began to cross in this shared desire to save, or preserve aspects of the past, the history-makers embody the increasingly 'entangled' ${ }^{3}$ national and imperial belonging of the New Zealand public between the end of the Anglo-South African and the beginning of the Great War.

As Stafford and Williams articulate, Maoriland can be framed as the period in which New Zealand settler society 'consolidated itself economically and culturally.' ${ }^{4}$ While this was alluded to in the work of Cowan and Robley in the first chapter, it becomes increasing apparent in their work in the new century, Robley engaging in debate surrounding Māori antiquities and Cowan starting a new role

\footnotetext{
${ }^{1}$ Blackley, Galleries of Maoriland, p. 183; Peter Gilderdale, 'Stoic and Sentimental: The Emotional Work of the Edwardian Greetings Postcard', JNZS, No. 22, 2016, p. 4.

2 Stafford and Williams, p. 11.

${ }^{3}$ See Hunter, 'National and Imperial Belonging in Wartime’, p. 32.

${ }^{4}$ Stafford and Williams, p. 14.
} 
at the Department of Tourist and Health Resorts. ${ }^{5}$ In these realms Cowan and Robley were both creating a sense of Māori prehistory of the land, in a way that Peter Gibbons has termed as 'cultural colonisation' by Pākehā intellectuals from the 1890s. ${ }^{6}$ That is, Gibbons has argued, the production or invention of 'the Māori' for the purposes of Pākehā of an early national identity. ${ }^{7}$ However, as Tony Ballantyne and Roger Blackley have both argued, Gibbons' argument has a 'hegemonic' nature for the way it omits moments of Māori agency and collaboration in the culture of Maoriland during the period of this discussion. ${ }^{8}$ Gibbons' argument, with its focus on literature does have particular relevance to Cowan and Robley's histories after the First World War. ${ }^{9}$ But this discussion, similar to Blackley's own analysis of 'Pākehā Propaganda' and Cowan and Robley's dubious contemporary Trevor Lloyd, ${ }^{10}$ looks at the earlier, alternative articulations of Pākehā identity before the war threw the sense of nationhood into sharp relief. Meanwhile, Statham, who begins work with the Victoria League, strengthening cultural ties with the imperial motherland in the name of Queen Victoria herself, adds an important new dimension of Pākehā concerns during the height of Maoriland discourse. It was one thing to utilise Māori culture for a cultural and economic purposes, bringing 'Maoriland into national and international focus. ${ }^{11}$ But perhaps surprisingly, it was Statham at the Victoria League who was the first to attempt to draw Māori into imperial and martial recognition in an effort to preserve the memory of the men who had fought for empire on New Zealand soil. Statham's primary concern during this 1901-14 period, was to highlight the imperial duty of being proximate to the place where imperial soldiers had fallen, to record their memory on site. The 1901-14 period thus marks the era in which the three began deliberating what parts of the New Zealand past were of value to informing collective belonging whether it be to the new country locale or to a British imperial order.

The discussion begins by looking at what Robley deemed as valuable to informing New Zealand's local identity when he began to market his collection of mokomokai to the New Zealand government, hoping to have his collection purchased for its national importance. Turning then to Cowan, the discussion looks at his move to Wellington in 1902, where he begins his position at the Department of Tourist and Health Resorts with Superintendent of the Department Thomas E. Donne, another crucial player in Maoriland's culture of display. From the end of Cowan's time at the Department in 1909, the discussion then turns to Statham and the Victoria League, her Auckland Branch having been assembled within the same year. One of the founding objectives of the League was the recognition of those who fell in the South African War, which inspired the Auckland branch to consider tending to the 'gravesites of those who fell in the Maori wars', and it is this area in which Statham made

\footnotetext{
${ }^{5}$ Blackley, Galleries of Maoriland, p. 21

${ }^{6}$ Gibbons, p. 6

${ }^{7}$ Ibid, p. 13.

${ }^{8}$ Ballantyne, p. 291; Blackley, Galleries of Maoriland, p. 11.

${ }^{9}$ Gibbons, p. 6.

${ }^{10}$ Blackley, Galleries of Maoriland, pp. 183-189.

${ }^{11}$ Ibid, p. 189.
} 
a name for herself in her new Auckland context. In this work, Statham would catch the eye of the Minister of Internal Affairs, Francis Bell, who, in 1913, would offer her a position to continue the work under government contract. After exploring some of Statham's early work with soldier graves, the discussion returns to Robley, who around the same time, began to explore the picture postcard as another way to communicate what he saw as valuable to a sense of New Zealand's local fashioning. The chapter will end by looking at Robley's 1914 depiction of 'the Maorilander's greeting to Kaiser Bill' as a product of the merging sentiments of a Maoriland locale and imperial allegiance and informed by an increasingly martial historical focus in New Zealand.

From the turn of the century Robley began his formal attempt to have his collection of mokomokai purchased by the New Zealand government in his belief that they held particular national value to the place from where they had originated. While there were those close to Robley who supported his claims of the collection's public value to New Zealand, as well as at least some of the general public in New Zealand, Robley's efforts occurred at a particular time of debate about the place of Māori antiquities in the development of a national museum collection. According to Robley, the first time he had made an offer of sale of his collection of mokomokai had actually occurred at the Holborn Restaurant in London at the time of the Queen's Diamond Jubilee back in 1897, where he had meet Premier Seddon for the first time. ${ }^{12}$ Recalling the event to Fildes twenty years later, Robley claimed that he had intimated repatriating the mokomokai back to New Zealand in conversation with Seddon at the event, who had responded in support of the proposition. ${ }^{13}$ According to Robley, there were already opposers within the government who had refused the offer by wire the same day Seddon departed by ship. ${ }^{14}$ Seddon's supposed interest in the collection did seem to corroborate his interest in creating a cultural locale in New Zealand. He had, according to biographer Tom Brooking become intimately involved in the climate of Maoriland through his 1903 provision for a 'New Zealand Intercolonial Fair' which would become the Christchurch International exhibition in $1906 .{ }^{15}$ Boasting an array of exhibits that demonstrated New Zealand's exemplary settlement and development, the exhibition also included an array of ethnological displays to bring the ancient Māori world into view for visitors. ${ }^{16}$ There is also some sense that Robley would be hopeful of Seddon being a potential ally for his hopes of repatriation

\footnotetext{
12 Blackley, Galleries of Maoriland, p. 209.

${ }^{13}$ Robley, 'Chapter on Maori Art Collecting and Book Thereon', c. 1919, FILD00057, JCBR, p. 14.

${ }^{14}$ Ibid.

15 Tom Brooking, Richard Seddon: King of God's Own, (London: Penguin Books, 2014), p. 396.

${ }^{16}$ Ibid, p. 398.
} 


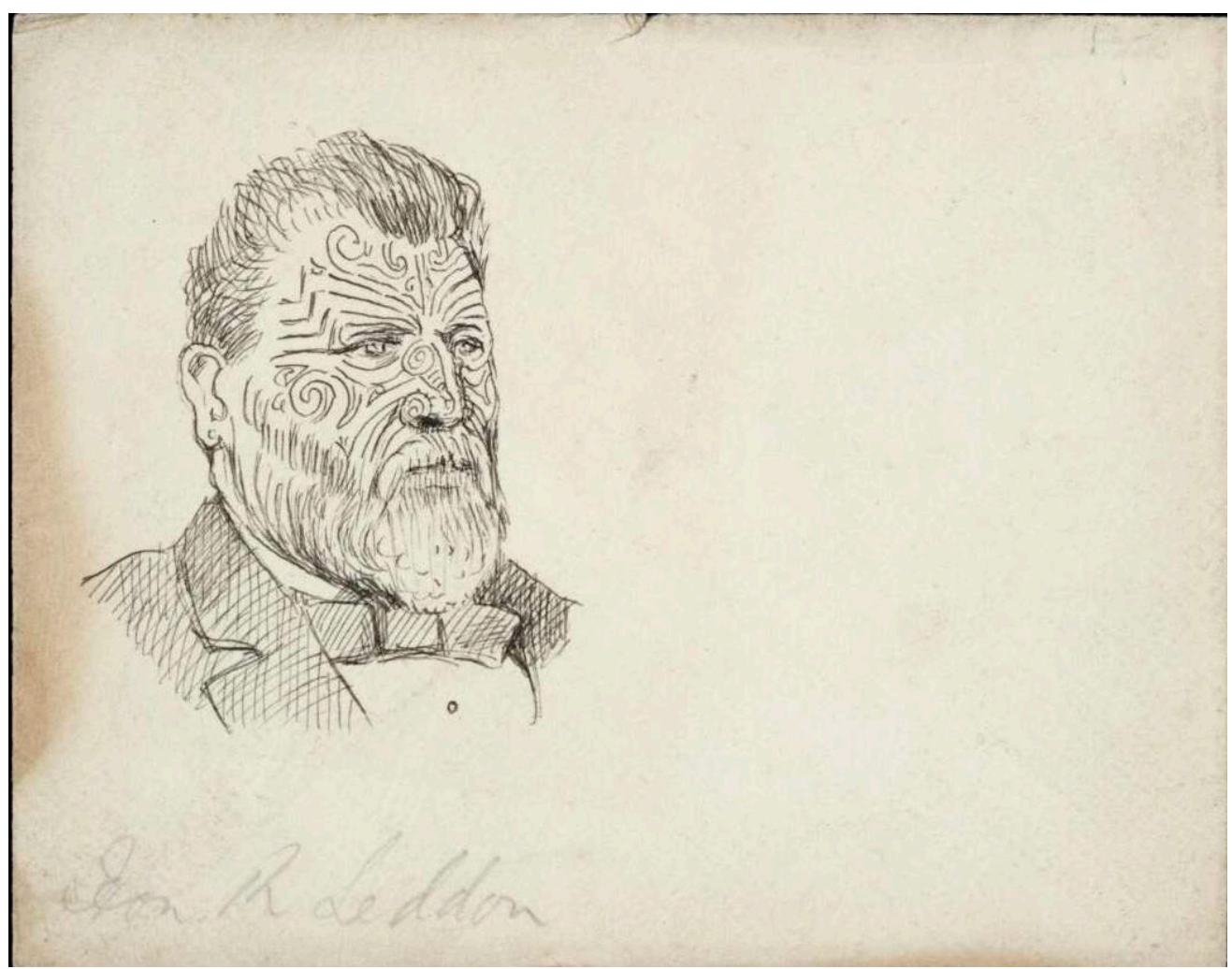

Fig. 2 - Horatio Gordon Robley, 'Hon. R. Seddon', ca. 1890, E-280001, Alexander Turnbull Library, Wellington.

at the time, as illustrated by a sketch Robley had done of the Premier with a full tā moko [see fig. 2]. The sketch has been dated by the Alexander Turnbull Library as being from 1890, the year Seddon and the Liberal Party had won the election. But given Robley's penchant for bringing moko and Māori culture into topical interest as he had with his portrait of Paul Kruger, it is just as possible that Robley had completed this sketch in reference to Seddon's premiership from 1893, or after Robley met Seddon in London in 1897, or in response to the resounding triumph of his Liberal Government in 1899, the same year that Seddon sent a colonial contingent to aid empire against Kruger's Boer forces. ${ }^{17}$ Regardless of its exact provenance, the image of the Seddon provides an important visual demonstration of the hopes that Robley had for his work on moko and the place of the mokomokai in New Zealand in the new century.

Aside from Seddon's early vote of support, there were other examples of support for the collection's repatriation to New Zealand. In an article in the Thames Star in October 1901, a London correspondent of the Bulletin (or perhaps from Robley himself) was quoted to the effect that highlighted the value of a collection like Robley's at the time in a tongue-and-cheek fashion:

The finest and rarest collection of Maori relics in or out of Maoriland is in the possession of Major General Robley who fought for some purpose in the native wars of Seddonia. No museum in Maoriland, nor the pick of all museums can compete against the British Soldier's little lot. [The Collection is] superb - in the expert antiquarian's eyes. To the man-in-the-

\footnotetext{
${ }^{17}$ Ibid, p. 188.
} 
street... They are bunched in their cupboard shelves, devilish scaring... Recently a wealthy Austral offered $£ 4000$ odd for the collection, and the offer was accepted on condition that it did not leave England. Perhaps King Seddon, however, can win these treasures back to their homeland. ${ }^{18}$

The 'expert antiquarians' in New Zealand who respected Robley's collection included the likes of Dr Thomas Hocken an ethnologist and collector from Dunedin. Hocken sent a letter to Robley in 1902 stating; 'Not only is your collection unique but it typifies a branch of savage art that is most interesting and one which as now almost wholly disappeared. ${ }^{19}$ According to Robley, the two had met in Italy during his years of collecting mokomokai and taking sketches from European exhibits and the two had maintained a collaborative relationship on the topic throughout the years before Hocken's death in 1910. ${ }^{20}$ Hocken’s letter echoed the lamenting nature of Grey's words in Moko; or Maori Tattooing, that Robley had saved something that was otherwise going extinct, preserving the memory of this 'branch of savage art.' Robley had also, in 1902, been visited by a contingent of Māori soldiers in London for King Edward's coronation, and according to Robley, the opinion of these Māori soldiers was that the collection was 'a treasure of their art' and should be returned to their land. ${ }^{21}$ There was a sense that Robley's collection had value in New Zealand as relics of a Māori prehistory and as treasures of the colonial modernity of 'Seddonia.'22 But as this last example illustrates, there were reasons for the collection to be repatriated outside of a project of settler-colonial self-fashioning.

According to Timothy Walker, it was in 1899 that Robley had officially placed the collection under formal offer to the New Zealand government. ${ }^{23}$ Little is known about the conditions of this initial offer, but in a letter to Hocken in August 1900, Robley reported that the government had not answered his communication. ${ }^{24}$ In April of 1902, Robley reported to a New Zealand Herald correspondent that he had offered the New Zealand government his entire collection of 'Maori art', including carvings, pounamu, 'fighting weapons' along with the entire collection of mokomokai 'on very easy terms' back in June of $1901 .^{25}$ Incensed by their lack of response to this 'priceless' offer, Robley told the correspondent that former governor Lord Onslow whom Robley had presumably met through his connection to the agent-general's office in London, had 'written out to the colony strongly recommending its acquisition. ${ }^{26}$ Robley sold the rest of the collection and kept the mokomokai,

\footnotetext{
18 'Maori Relics', Thames Star, 8 October 1901, p. 2.

${ }^{19}$ Horatio Gordon Robley, 'Chapter on Maori Art Collecting and Book Thereon', c. 1919, FILD00057, JCBR, pp. 13-14.

${ }^{20}$ Horatio Gordon Robley to Elsdon Best, undated, MS-Papers-0072-05A, ATL; Walker, 'Robley: Te Ropere 1840-1930', p. 73.

${ }^{21}$ Horatio Gordon Robley, ‘Army Service from 1858’, c. 1919, FILD00056, JCBR, p. 72.

22 Blackley, Galleries of Maoriland, p. 48.

${ }^{23}$ Walker, 'Robley: Te Ropere 1840-1930’, p. 6.

${ }^{24}$ Ibid.

25 'Personal Items from London', NZH, 7 April 1902, p. 6.

26 Ibid.
} 
reporting the interest of an American Museum to the New Zealand correspondent. ${ }^{27}$ It is no wonder then that Robley's next move was to focus more on those elite 'experts' who he know would value the collection the way he did. In December of 1902 it was reported in the New Zealand Times and the Evening Post that Robley had 'intimated' an offer to the Wellington Philosophical Society. ${ }^{28}$ The Christchurch Press gave further detail to this claim by reporting that Robley had initially approached the New Zealand Institute (that incorporated the Wellington Philosophical Society) for the sale but due to the too high a price of $£ 1850$, had been put through to the government. ${ }^{29}$ The founding principles of the institute were 'to promote the general study and cultivation of the various branches and departments of art, science, literature and philosophy. ${ }^{30}$ It is therefore unsurprising that Robley viewed it as means of either finding a buyer who saw the fine art value in the collection or at least a means of fostering some support amongst those with intellectual standing in the colony.

At the time that Robley was making these initial offers, the New Zealand government was also deliberating about the development of a 'national museum' particularly in relation to the organising a representative display of Māori ethnographic art. By 1901 the collections of the colonial museum, housed in a wooden, borer-prone building, which stood behind the parliamentary buildings in Wellington, were looking increasingly outdated. ${ }^{31}$ Director of the museum James Hector, had failed to keep up with the developments in the educational use of the specimen object, and the colonial museum appeared more like a 'cabinet of curiosities' rather than a scientific display. ${ }^{32}$ The crammed array of disparate items at the colonial museum stood in contrast to the work of Thomas Cheeseman at Auckland Museum who by this point had separated the Māori ethnographic items out and displayed them in the taxonomic, scientific fashion. ${ }^{33}$ It was also increasingly apparent, particularly through the generous giftgiving of Rotorua iwi during the Royal tour of 1901, that Māori objects were leaving the country at an alarming rate, which concerned not only Pākehā salvage ethnologists, but also some Māori who were increasingly active in the preserving of their own past. ${ }^{34}$ It was this set of events that brought the collaborative effort of Augustus Hamilton, who had just published Maori Art, and native minister (and close ally of Seddon), James Carroll in the development of the Maori Antiquities Act 1901. ${ }^{35}$ The act predominantly focused on the government's responsibility to provide a 'National Maori Museum, for the preservation of the antiquities of the Polynesian race. ${ }^{36}$ In a separate document Hamilton used to

\footnotetext{
27 Ibid.

${ }^{28}$ New Zealand Times (NZT), 17 December 1902, p. 4; 17 December 1902, p. 4.

${ }^{29}$ Press, 17 December 1902, p. 7.

${ }^{30}$ New Zealand Institute Act 1867, No. 36; http://nzlii.org/nz/legis/hist_act/nzia186731v1867n36364/; accessed 19 May 2021.

31 'The New Museum', EP, 2 June 1909, p. 3; accessed 5 April 2021.

${ }^{32}$ Conal McCarthy, Exhibiting Maori, p. 43.

33 Ibid, p. 45.

${ }^{34}$ Ibid, pp. 50-51.

35 Blackley, Galleries of Maoriland, p. 80.

36 "The Maori Antiquities Act, 1901", Appendix to the Journals of the House of Representatives (AJHR), 1901, Session I, G-08, p. 1.
} 
promote the national museum idea described it as 'a Valhalla for Maori, a place in which the memories of their great ones can be enshrined and perpetuated. ${ }^{37}$ According to Blackley, in his formative role Carroll articulated the wider support from leading chiefs that the museum could be a 'decisive asset for the benefit of Māori. ${ }^{38}$ Furthermore, the act's limitation on exporting Māori antiquities amongst other stipulations, give an element of protection and agency, after a period in which the pillaging behaviours certain collectors had created a rightful distrust between many Māori and those Pākehā engaging in display culture. ${ }^{39}$

In May 1902, it was reported in the New Zealand Herald that Carroll had received the deputation of members of the council of the Auckland Institute along with some interested members of the Auckland public on the topic of the Māori Antiquities Act. ${ }^{40}$ The primary concern of the deputation was the potential location of the proposed national museum, arguing that such a national collection should be held at the Auckland Museum not just because of the efforts of Cheeseman and the institute to make the 'collection of articles representing Maori art' as reputable as it was. But also because of the Auckland Public had previously raised the funds to buy new collections for the Auckland Museum and felt deserving of recognition of such public display of support. ${ }^{41}$ As Blackley has illustrated, Auckland had been the home of key Maoriland instigating organisations such as the Auckland Society of Arts, the New Zealand Art Students' Association and the Lindauer Art Gallery (with accompanying biographies written by James Cowan) operating nearby. ${ }^{42}$ However, the deputation was not merely concerned with location of the national collection. It was also reported that local liberal politician George Fowlds who was part of the deputation, had pressed Carroll on Robley's 'offer' of his collection to the New Zealand government. ${ }^{43}$ It appeared from this interaction that not only did the concerned members of the Auckland public want Robley's collection in New Zealand, they also saw it as part of a prospective national, Māori ethnological art collection. The sentiment would be echoed in March the following year in a letter to the New Zealand Herald editor by William J. Napier, who would later come be involved in the Victoria League alongside Statham. ${ }^{44}$ In his letter, Napier described the potential loss of Robley's collection as a ‘national calamity', particularly Napier argued, if the collection were to end up with the German scientists who had also taken interest. ${ }^{45}$ The collection was seen as valuable to the memory of a New Zealand past, to Napier its loss would not only impact New Zealand as a nation but also threatened to fall into the hands of the enemy of empire.

\footnotetext{
${ }^{37}$ Blackley, Galleries of Maoriland, p. 80.

${ }^{38}$ Ibid.

${ }^{39}$ Ibid, p. 158.

40 'Collection of Maori Curios', NZH, 26 May 1902, p. 7.

${ }^{41}$ Ibid.

42 Blackley, Galleries of Maoriland, p. 32; Blackley, 'The Plutarch of Maoriland', p. 111.

43 'Collection of Maori Curios', NZH, 26 May 1902, p. 7.

44 'Maori Curios in England', NZH, 21 March 1903, p. 6 (supp.).

45 Ibid.
} 
However, it was James Carroll's response to Fowlds in the 1902 that marked the beginning of the end of Robley's attempt to have the heads repatriated back to New Zealand, stating that: 'the cabinet did not consider that it should be purchased. It consisted mainly of preserved heads and was thought to be too gruesome. ${ }^{46}$ It is unclear whether this was immediately relayed to Robley as the reason that he had not received a response to his initial offers nor was it clear form this passage that Carroll was solely responsible for the rejection. According to Walker however, in May of 1906 Robley received word that Carroll was primarily responsible for the rejection. ${ }^{47}$ According to an article published in the Evening Star in December of 1907, Robley had re-offered the collection to the government, most likely at a lower rate and after waiting eighteen months, again with no response, he formally withdrew the offer. ${ }^{48}$ The article went on to suggest that perhaps the government could be forgiven for not wanting the 'grisly relics of inter-tribal strife for the purpose of exhibiting them in the public museums of the Dominion' ${ }^{49}$ Another published in the Observer four days later echoed the sentiment; 'It has been stated and reiterated that the collection is unique of its kind. Probably it is, but uniqueness is not the sole desideratum in the formation of our museums. Haven't we had enough of such grisly specimens along the way? 50

While Carroll's exact sentiment about the collection is unknown, and as these articles demonstrate, he was far from the only one in New Zealand questioning their value in the national museum, this did not stop Carroll from becoming the sole focus of Robley's outrage at the rejection. In conversation with a London correspondent for the Evening Star in 1907, Robley suggested that Carroll's refusal was due to his inferior lineage:

The personage advising the Government is either content with the four specimen heads now in New Zealand museums, or is so ignorant of the history of the country that he imagines it was only slaves that left their heads on the tribal battlefields, or that he has no sympathy with tatus of rank because he could boast none in his own family. ${ }^{51}$

Robley felt so strongly about the role that Carroll's lineage (perhaps in reference to Carroll's mixed lineage) played in his refusal of the collection that he was still asserting it as the reason for the rejection to Horace Fildes twelve years later. ${ }^{52}$ In reality, if Carroll had been responsible for the rejection it may have been because the collection did not suit his vision of the national Māori antiquities collection at a time when he, along with other Māori MPs, were navigating an era of assimilatory policies to advance

\footnotetext{
46 'Collection of Maori Curios', NZH, 26 May 1902, p. 7.

${ }^{47}$ Walker, 'Robley: Te Ropere 1840-1930’, p. 8, 18.

${ }^{48}$ Ibid, p. 8; ES, 24 December 1907, p. 6.

${ }^{49} E S, 24$ December 1907, p. 6.

50 Observer, 28 December 1907, p. 4.

${ }^{51}$ ES, 24 December 1907, p. 6.

52 Horatio Gordon Robley, 'Chapter on Maori Art Collecting and Book Thereon', c. 1919, FILD00057, JCBR, pp. 14-15.
} 
Māori interests. ${ }^{53}$ Nevertheless, to Robley, in the moment of rejection, his expertise with moko and mokomokai outweighed Carroll's opinion when it came to deciding what parts of New Zealand history were deserving of representation in a national museum collection.

For Robley back in London, whatever the reason for it, the rejection was a major disappointment. Not only was it a rejection of his life's work since retirement, but also because of the lost opportunity to potentially visit to the country that had shaped him so profoundly as a young junior officer. In a letter to his old comrade, Gilbert Mair, in April 1906, Robley expressed the wish to 'go rounds of New Zealand again' and as Walker has argued, there is a sense in Robley's correspondence during this time that in offering his collection to the New Zealand government, he had also anticipated a passage back to New Zealand. ${ }^{54}$ Robley's desire to return to New Zealand was not just about taking his place in the pantheon of Pākehā 'expert antiquarians.' The potential of reuniting with his son, Hamiora Tu Ropere, and now grandchildren, also played a significant part in his emotional ties with the country. ${ }^{55}$ In 1907, Robley reportedly accepted an offer of $£ 1,500$ for all but five of the mokomokai from the American Museum of Natural History in New York. ${ }^{56}$

However, the rejection and consequential sale to an American buyer, did not spell the end of his contribution to exhibitory representations of a New Zealand past. In May of the same year, though it is unclear whether it happened before or after the sale, Robley was able to exhibit 'some' of his collection for another Premier, Joseph Ward, who was in London to attend the 1907 Imperial Conference. ${ }^{57}$ While he was not able to get the mokomokai into a national museum in New Zealand, in December of 1905, Superintendent of the Department of Tourist and Health Resorts, Thomas E. Donne quietly secured seventy of Robley's sketches and watercolours. ${ }^{58}$ The collection that primarily depicted scenes of Robley's New Zealand Wars experiences was acquisitioned into the Colonial Museum's collections but was not put on display right away. ${ }^{59}$ This was the first indication in the work of the three history-makers, that the colonial wars between settler and imperial forces and Māori had potential to be a central historical focus. But in 1905, Hamilton, who had by then taken up the directorship at the Colonial Museum, along with other Pākehā ethnologists, appeared more interested in 'penetrating the mist of Māori prehistory' to find a narrative of a New Zealand locale than attempting to incorporate the instances of colonial conflict of a more recent era. ${ }^{60}$ By the time the sketches and watercolours would go on display in 1914, they would have a new sense of value for their depictions of a moment of martial significance in New Zealand's past.

\footnotetext{
53 Blackley, Galleries of Maoriland, p. 79.

${ }^{54}$ Walker, 'Robley: Te Ropere 1840-1930’, pp. 8, 57.

55 Ibid, pp. 42-43.

${ }^{56}$ Ibid, p. 9.

57 'Anglo-Colonial Notes', Lyttelton Times, 24 May 1907, p. 4.

${ }^{58}$ NZT, 16 December 1905, p. 5.

59 Ibid.

${ }^{60}$ Blackley, Galleries of Maoriland, p. 46; McCarthy, Exhibiting Maori, pp. 46-47.
} 
While Robley was navigating the complexities of Maoriland in the new century, Cowan went from reporting on Māori Affairs at the Auckland Star, to transforming that knowledge into marketing New Zealand at the Department of Tourist and Health Resorts. The Department had been the brainchild of Joseph Ward, then Minister of Railways, who selected his friend Thomas Donne to be superintendent of the new government initiative for tourism publicity. ${ }^{61}$ When it opened in February 1901, the Department had clear aspirations for how it wanted to present New Zealand to visitors, exemplified by its cable address simply being 'Maoriland. ${ }^{\text {' } 2}$ Developed in response to over thirty years of a growing tourist trade in New Zealand, when Cowan moved to Wellington to join the Department in 1903, the government-directed initiative was firm in its role in what Cowan himself described as 'pioneering the country for the pleasure-hunter. ${ }^{63}$ It was here where he met superintendent Donne. As Margaret McClure has discussed, Donne spearheaded the Department in promoting New Zealand as an exotic and exciting destination for European travellers. ${ }^{64}$ The appeal of New Zealand as an attractive destination had to be made by rhetorically and discursively looking inwards.

Cowan's tourist 'literary matter' helped create and devise the theme of the Department itself, providing a visual of wild exploration in outside the New Zealand city whereby Māori culture was present and central but also naturalised as part of that environment. This was particularly pertinent to the 'geyserland' of the Rotorua area where the Department set up the first agency for tourists the year Cowan started in $1903 .{ }^{65}$ Aside from marvelling at the geothermal activity of the area, tourists could visit villages like Whakarewarewa where local Māori guides would lead them through the daily life of a traditional Māori village. ${ }^{66}$ For Cowan in 1903, the primary task was to publicise not the already buzzing tourist destinations of the Rotorua area but also those areas previously untouched by tourist visitation. ${ }^{67}$ Keeping with this work, Cowan left Wellington in 1905 to tour the South Island, where the rugged and wild landscapes would provide a 'spice of adventure' for Cowan's travel guides. ${ }^{68}$ In the first apparent indication that Cowan and Robley would become collaborators in their work, when Cowan was in the South Island, he sent a letter directly to Robley reporting on some of the moko he had come across in his visit to 'various Maori Kaingas. ${ }^{\text {'69 }}$ It appeared from the correspondence that Cowan had read Robley’s work, and the letter was part of an established discussion between the two

\footnotetext{
${ }^{61}$ Margaret McClure, The Wonder Country: Making New Zealand Tourism, (Auckland: Auckland University Press, 2004), pp. 26-27.

${ }^{62}$ Blackley, Galleries of Maoriland, p. 228.

63 James Cowan, New Zealand or Ao-tea-roa, (Wellington: Dept. of Tourist and Health Resorts, 1908), p. 19 as cited in McClure, p. 29.

${ }^{64}$ McClure, p. 30.

65 Ibid, p. 59.

${ }^{66}$ Ibid, pp. 31-32.

${ }^{67}$ Colquhoun, 'Cowan, James', DNZB, Te Ara, 1996.

${ }^{68}$ Ibid; McClure, p. 65.

69 James Cowan to Horatio Gordon Robley, 30 May 1905, 'Horatio Gordon Robley - Inward Correspondence’, MS-Papers-1387-12, ATL.
} 
about the origins of moko, with Cowan suggesting that the examples found demonstrate a similar lineage to Marquesan tattoo. ${ }^{70}$

This trip to the South Island was one part of Cowan's nationwide tour which would come to provide the materials for his most definitive work with the Department, New Zealand;or Ao-tea-roa published in 1907. New Zealand or Ao-tea-roa typified the Department fostering of a tourist industry based on a cultural performance of an ancient Māori past, particularly in those chapters dedicated to the scenery of the North Island. In his section on Geyserland, Cowan utilised imagery of Māori performing 'traditional' tasks in his description of the scenery: 'Maoris [paddle] their canoes over the calm blue lakes, and [spend] their untroubled days lounging in baths of Elysian warmth and softness. ${ }^{71}$ The South Island Cowan wrote, 'with its great snowy range, its rushing ice-fed rivers, windy tussock-grassed plains, and dark illimitable forests, was less suitable a home for the Maori. ${ }^{72}$ But it provided the perfect climate for the modern day traveller or 'sportsman-tourist. ${ }^{, 73}$ In a separate section dedicated to an ethnological discussion of Māori culture itself, Cowan included a sketch by Robley as an example of moko, perhaps as a product of their correspondence at the time. ${ }^{74}$

The guidebook also provided a description of the Department itself, as well as some of its affiliated concerns. As McClure argues, the Department's goal was not just to draw in 'pleasureseeking' tourists but also prospective permanent settlers. ${ }^{75}$ Cowan highlighted this in New Zealand or Ao-tea-roa when he directed readers toward Donne's other affiliated government agency:

A useful informative office associated with the Department of Tourist and Health resorts is the Department of Industries and Commerce, of which T.E. Donne is also the executive head. The chief objects of the department are to supply information regarding the world's market to New Zealand exporters... to see the country's produce and manufacturers are placed upon British or foreign markets in a condition best suited to merchants and customers... and to give reliable information to persons in any country who may desire to settle in New Zealand... ${ }^{76}$

While there had always been commercial considerations in the activities of Maoriland, Cowan's inclusion of this detail in a book about tourism signified a general promotion of New Zealand beyond just tourism.

Cowan's statement from New Zealand or Ao-tea-roa also highlights the important relationship the Department would hold with the New Zealand image in London. As Felicity Barnes has argued the

\footnotetext{
70 Ibid.

${ }^{71}$ Cowan, New Zealand or Ao-tea-roa, pp. 58, 97, as cited in Gentry, p. 34.

${ }^{72}$ Cowan, New Zealand or Ao-tea-roa, p. 5.

${ }^{73}$ Ibid, p. 10.

${ }^{74}$ Cowan, New Zealand or Ao-tea-roa, p. 73.

${ }^{75}$ McClure, p. 57.

${ }^{76}$ Cowan, New Zealand or Ao-tea-roa,p. 19.
} 
New Zealand High Commission, although its purpose would shift drastically by 1914, was initially a place where New Zealand's interests would be represented in the metropole. ${ }^{77}$ As McClure argues, Pember Reeves who had held the Agent-General position from 1896, held the belief from the time he took the position that it was the responsibility of the Agent-General's office in London to provide consistent advertising that could work in conjunction with the systemisation of the tourism industry. ${ }^{78}$ It is no wonder then that upon its publication in 1907, Reeves requested that Prime Minister Joseph Ward send him 500 copies of Cowan's New Zealand publication, to which Ward sent him 500 copies. ${ }^{79}$ The intimate connection the work of the Tourist Department and High Commission was further exemplified by Donne's transfer from superintendent of the Tourist Department to being selected as the new 'commercial and immigration advisor' to the High Commissioner in London in $1909 .{ }^{80}$ Cowan, also left the Department in 1909, taking up freelance writing instead. ${ }^{81}$ Though Cowan and Donne went in separate directions they remained in contact. Donne, who had secured Robley's sketches and watercolours of colonial war subjects in 1905, would later demonstrate avid support of Cowan's later historical work.' 82

Another significant product of Cowan's time with Donne and Department of Tourist and Health Resorts, was his account of 'Pakeha-Maori', Kimble Bent. When Cowan moved to Wellington in 1903, Donne introduced him to Kimble Bent after inducing Bent to come to Wellington to be interviewed and photographed. ${ }^{83}$ Bent, who had deserted the British Army and joined the Hauhau forces in Taranaki around the same time that Robley had begun his leave with Mair and the Arawa forces in 1865, was an example of what Cowan described as a 'nearly extinct type of decivilised outlander', a 'pakehaMaori. ${ }^{, 84}$ It was thus through the specific symbol of Bent as a Pākehā-Māori, that Cowan would first broach the subject of the wars in New Zealand as a valuable moment of the New Zealand past. After Cowan interviewed Bent he published the narrative as a weekly newspaper serial in the Auckland Star from 1906, then after his contract with the Department had ended, Cowan published the full Adventures of Kimble Bent narrative as a book in $1911 .{ }^{85}$ According to Cowan, Bent embodied the quintessential Pākehā-Māori character, not just through the thirteen years spent with the Hauhau forces, but because of series of qualifiers in the way he engaged with Māori culture:

\footnotetext{
${ }^{77}$ Felicity Barnes, New Zealand's London: A Colony and its Metropolis, (Auckland: Auckland university press, 2012), p. 46.

${ }^{78}$ McClure, p. 25.

${ }^{79}$ Joseph Ward to William Pember Reeves, 9 March 1908, 'Outwards Letterbook - High Commissioner 19051913', ACGO 8336, IA 4, Box 168, Item 171, ANZ.

${ }^{80}$ [The role of Agent-General was substituted by the role of High Commissioner in 1905, and Pember-Reeves was appointed to the new position] ES, 17 March 1909, p. 4.

${ }^{81}$ Colquhoun, 'Cowan, James', DNZB, Te Ara.

82 Thomas E. Donne to James Cowan, 17 June 1918, 'Correspondence with Jim’s Friends’, MS-Papers-11946173, ATL.

${ }^{83}$ James Cowan, Adventures of Kimble Bent, (Christchurch: Whitcombe and Tombs, 1911), p. ix.

${ }^{84}$ Ibid, p. $x$.

${ }^{85}$ James Cowan, 'The Adventures of Kimble Bent', AS, 15 September 1906, p. 9.
} 
He has been out of bush exile many years, but is still living with his Maori friends, and is still known by his Maori name, Tu-nui-a-moa, which his chief Titokowaru gave him in 1868. When he writes me, he usually writes in Maori, and he is practically Maori himself, for he has lived the greater part of his life as a Maori, and he has assimilated the peculiar modes of thought and some of the ancient beliefs of the natives, as well as their tongue and customs. ${ }^{86}$

By 1911 Cowan seemed increasingly interested in the topic of Pākehā-Māori, and in the same year published an article on another infamous Pākehā-Māori, Barnet Burns. ${ }^{87}$ Cowan’s Pākehā-Māori publications served as an evocative end to a decade of promotional renderings of Māori culture, not just about Māori but about New Zealand as a whole. Cowan had gone from espousing the 'settler dreamtime' of tourist literature, presenting New Zealand landscapes as accessible and alluring, with Māori as an ancient, almost mythical, backdrop. ${ }^{88}$ In Bent's narrative, Cowan began to broach the subject of Māori defiance to settlement in New Zealand, but only for how it shaped the character of his Pākehā-Māori protagonist. It would not however, be the last time that Cowan would revisit Māori defiance or the colonial wars as a historical project. Two years after he published Adventures of Kimble Bent, Cowan remarried, following the death of his first wife Eunice in 1909, this time to Eileen Stowell, daughter of Māori scholar Hāre Hongi (Henry Stowell). ${ }^{89}$ The couple relocated to Christchurch, with Cowan also moving back into full time newspaper work for the Christchurch Star and Lyttelton Times. ${ }^{90}$

Edith Statham appeared comparatively quiet at the time that Robley and Cowan were attempting to create New Zealand as a destination and a settler locale, but as a few infrequent local newspaper reports suggest, she was just as active on a community level. Not only had she taken up the position as honorary secretary of the Auckland branch of the Women's Christian Temperance Union, she had continued to pursue her interest in cycling, becoming the assistant secretary of the (male and female) Auckland Cycle Roads League. ${ }^{91}$ It appeared from these engagements that Statham was still very much concerned with pursuing a progressive female citizenship as she had done so successfully in Dunedin. While she had not gone to South Africa as a nurse, in March 1901 she continued with a sense of duty to the war when she collaborated with a group of other Auckland women, including the wife of George Fowlds, to organise a reception for returning 'imperial troops. ${ }^{92}$ The notice of her collaboration on the reception came two months after the death of Queen Victoria in England. A month later a group of women in London came together to establish a 'women's association', named 'in the memory of our

\footnotetext{
${ }^{86}$ Cowan, Adventures of Kimble Bent, p. viii.

${ }^{87}$ James Cowan, 'Barnet Burns the Tattooed Trader’, The Weekly Graphic and New Zealand Mail, 5 July 1911, 'Correspondence and Papers about Moko’, MS-Papers-11310-11, ATL.

88 Turner, pp. 35-36.

${ }^{89}$ Colquhoun, 'Cowan, James', DNZB, Te Ara.

${ }^{90}$ Ibid.

91 'Cycle Boards Bill’, AS, 15 March 1901, p. 2; ‘Advertisements’, AS, 27 July 1901, p. 2.

92 ‘Advertisements’, AS, 5 March 1901, p. 8.
} 
late Gracious Queen, and with the desire to continue the great work of closer union throughout the Empire for which she did so much'. ${ }^{93}$ Not only was the establishment of the League a response to Queen Victoria's death, but also reflecting a sense of duty like Statham's, of recognising the imperial soldiers who were still fighting in South Africa and to remedy the 'lack of arrangements' for those who had fallen on the Transvaal battlefields. ${ }^{94}$ Once established, the League formalised its guiding principles: 'The conservation in memory of Queen Victoria, of the deeds of British soldiers and sailors, and other patriotic men and women in the Empire, and the assistance and hospitality shown to overseas visitors in England. 95

According to Katie Pickles, the League quickly spread around the Empire, with the first in New Zealand appearing in Statham's old domain of Dunedin in 1905, after a member of the Dunedin elite, Mrs. W.H. (Rachel) Reynolds returned from England and had relayed the League's objectives. ${ }^{96}$ From the time the League was established in London, it had been the project of elite women who had sought to follow the example of Queen Victoria as an 'ultimate maternal icon', and 'mother of empire' ${ }^{97}$ As Julia Bush articulates, imperial organisations like the Victoria League often served the principles both 'female imperialists' and 'imperial feminists. ${ }^{98}$ For female imperialists, the maternalist aspect of the Victoria's memory aided their own position as mothers of the empire, which served a certain branch of elite white women's feminism in the increasingly maternalist welfare states of new world countries like New Zealand. ${ }^{99}$ According to Pickles, this was a prominent feature of the Victoria League's membership in Otago and New Zealand more widely, with the wives of colonial politicians and businessmen often leading the way. ${ }^{100}$ However as Bush argues it was the sense of imperial duty surrounding the Anglo-South African War that made the League attractive for 'imperial feminists':

They were organising for Empire upon a gendered basis, and thus publicly and privately asserting both women's ability to self-organise, and their entitlement (indeed, duty) to contribute to national greatness. On this basis, the ladies' imperialist associations were engaged in a process of self-reinforcement and redefinition of gender roles that had much in common

\footnotetext{
${ }^{93}$ Victoria League, 'Executive Committee Minutes', 2 April 1901, as cited in Julia Bush, 'Edwardian Ladies and the "Race" Dimensions of British Imperialism', Women's Studies International Forum, Vol. 21, No. 3, 1998, p. 281.

94 Bertram O. Stokes, A History of the Victoria League for Commonwealth Friendship in New Zealand, (Auckland, 1979), p. 1; Alma Newstead Simmons, Fifty Years of the Victoria League in Auckland, New Zealand 1910-1960: Golden Jubilee Year, (Auckland: Pelorus Press, 1960), p. 3.

95 Newstead Simmons, p. 3.

96 Pickles, 'The Victoria League in New Zealand', p. 34.

${ }^{97}$ Ibid, p. 32.

${ }^{98}$ Bush, p. 282.

${ }^{99}$ Ibid; Lake, p. 176.

${ }^{100}$ Pickles, 'The Victoria League in New Zealand', p. 35.
} 
with "imperial feminism." The definition of imperial duty and the redefinition of womanhood went hand-in-hand. ${ }^{101}$

This separation between the League's elite maternalism and duty to the imperial soldier is crucial for understanding how Statham as a single, non-elite woman, who had always sought economic independence, could view it as part of her ongoing pursuit of progressive female citizenship.

In 1909, an 'informal meeting of ladies’ was held at the Burleigh Street residence of Miss Ada Morrison in Auckland, to discuss the formation of a local branch of the Victoria League after the secretary of the London branch, Miss Meriel Talbot, had paid a visit to country. ${ }^{102}$ Statham was not present at the initial meeting in 1909, but after joining the League in early 1910, was quickly appointed as assistant secretary of the entire branch and by late 1911 she held the honorary secretary role. ${ }^{103} \mathrm{In}$ the first report of the Auckland branch of the Victoria League to the headquarters in London, Statham was touted for her 'strenuous' advocacy for the organisation's principles. ${ }^{104}$ In her role as Honorary Secretary Statham oversaw multiple organisational functions, some of which suggested an early crossover with Cowan's work at the Department of Tourist and Health Resorts. One such function was the 'Hospitality to Empire Visitors'. In the 1912 report to the members of the Auckland branch Statham outlined that if the League could ensure that visitors from the homeland were comfortable that it would 'do much to advance the cause of the work and bind our Empire closer together.' ${ }^{105}$ The League was very much concerned with fostering a welcoming environment for new settlers from Britain. In the same report Statham proposed the League 'induce educated women to come out to the Dominion' to facilitate an advisory system to promote and accommodate new settlement. ${ }^{106}$ Unlike the rhetoric of Maoriland however, the League was more concerned with fostering a sense of cultural belonging to empire rather than creating a sense of a distinctive locale. The Literature and Education committee for example, in an effort to get children in New Zealand to the standard of literacy back in England, began circulating English literature to 'lonely settlers in the back blocks' and their children. ${ }^{107}$ In the branch report from 1911-12 Statham noted that ten libraries had been sent to country schools, two parcels of literature to private individuals and that essay competitions amongst school children were all seen as opportunities to 'further the cause of the League. ${ }^{\text {'08 }}$ However, it was Statham's work as secretary of

\footnotetext{
101 Bush, p. 282.

102 'Victoria League: Aims and Objects', 18 November 1909, First Minute Book, 1909-1918, Box 43, NZMS

1244, GGSC; Pickles, 'The Victoria League in New Zealand', p. 34.

103 Newstead Simmons, p. 5.

${ }^{104}$ Hilda Carr Rollett, 'Victoria League of Auckland', The Victoria League Ninth Annual Report, 1910-1911, (2 Millbank House, Westminster, London S.W., 1911), p. 74.

105 Edith Statham, 'Report to the President and Members of the Victoria League', 7 March 1912, Box 43, NZMS 1244, GGSC.

${ }^{106}$ Ibid.

107 'Reports of the Branches: Auckland', Victoria League: Report of the Fourth Dominion Conference, 24-25 November, 1925, Box 37, NZMS 1244, GGSC, p. 3.

${ }^{108}$ Edith Statham, 'Report to the President and Members of the Victoria League', 7 March 1912, Box 43, NZMS 1244, GGSC.
} 
the Victoria League's 'Care of Soldiers' Graves Committee', that earned her a reputation as an 'enthusiastic worker for the cause' and would eventually bring her into direct engagement with both Robley and Cowan. This next section looks at the imperial lens with which Statham viewed commemoration for soldiers while she was still conducting the work with the Victoria League.

The Victoria League's founding concern for the 'lack of arrangements' for gravesites of imperial soldiers who had died on the distant battlefields of the Transvaal, brought about a particular inspiration for Statham and the League's Auckland branch. The league's alliance with the Guild of Loyal Women in South Africa from 1901, had been the primary way in which the League had ensured that gravesites of imperial soldiers there were being tended to. ${ }^{109}$ Drawing on this duty of the locale, it appeared that the Auckland branch of the league had recognised that there had been imperial soldiers who had fallen on New Zealand soil too, and their gravesites had not been tended to either. From the 'informal meeting of ladies' in 1909, a focus on the 'state of the gravesites of British soldiers who fell in the Maori wars' was listed as a primary objective. ${ }^{110}$ In a later 1911 letter to Liberal Auckland MP George Fowlds, who had previously supported the repatriation of Robley's collection of mokomokai, Statham made it clear that the 'Care of Soldiers' grave work was primarily a 'peg on which to hang imperialism.' ${ }^{111}$ League members immediately got to work attempting to 'arouse action' amongst Auckland city councillors to do something about the condition of the graves of soldiers buried in the Symonds Street cemetery. The response from the city council was read to a meeting of the branch's general council stating that they had regretted their 'inability to help [in] memorialising the graves of soldiers buried in Symonds St cemeteries', suggesting that it was because of funding limitations. ${ }^{112}$ By August of 1910 it had been decided that the League would appeal to the public for $£ 300$ and to the government to match the subscriptions pound for pound, to carry out the work of refurbishing the Symonds Street graves. ${ }^{113}$ It was around this point in time that Statham joined the League and was appointed to the Secretarial position of this committee.

According to Statham, in February 1911, the care of graves committee met with Prime Minster Joseph Ward, who promised the matter would receive immediate attention. ${ }^{114}$ However, before he could follow up in the matter, the committee had discovered that many of the graves had already lost their inscriptions, 'the very names of the men almost forgotten', Statham would later lament. ${ }^{115}$ Before Ward could get back to them, the committee turned to the Auckland City Council for assistance in creating

\footnotetext{
${ }^{109}$ Newstead Simmonds, p. 3.

110 'Victoria League: Aims and Objects', 18 November 1909, First Minute Book, 1909-1918, Box 43, NZMS 1244, GGSC.

111 Phillips, To the Memory, p. 36.

112 'Meeting of the general council', 17 August 1910, First Minute Book, 1909-1918, Box 43, NZMS 1244, GGSC.

113 Ibid.

${ }^{114}$ Edith Statham to Under Secretary James Hislop, 6 September 1915, ACGO 8333, IA1, 1287, 7/4/2, ANZ.

115 Ibid.
} 
one shared monument for the 'memory of officers and men of the Navy and Army and the Friendly Maories who fought for us in the Maori Wars. ${ }^{, 16}$ The Council responded by gifting a site for the memorial on the corner of Wakefield and Symonds Streets, and the committee made some initial designs for a monument that would cost between $£ 300$ and $£ 400$. By this point the committee met with Ward again, and presented him the shared monument designs, to which he responded by 'promising' $£ 100$ upfront and suggested that the committee approach the public for contributions too. ${ }^{117}$ By 25 February 1911, the committee published a notice in the Auckland Star that the government had offered $£ 100$ to $£ 100$ locally subscripted, going on to announce:

subscription lists will within a few days be placed in our banks, insurance offices and shops. The League hope that all will be represented on these lists; the soldier's widow with her mite, the cadet and the scout with his modest coin, as well as the prosperous and the always generous. ${ }^{118}$

In a report to the president of the branch in March by then secretary Mrs Hilda Carr Rollett, she noted that Ward had gestured for a further $£ 1000$ in assistance for the scheme, but there was no indication that this had been followed through at that time. ${ }^{119}$ Carr Rollett also reported that as Honorary Secretary of the committee, Statham, had not only been central to administering the communication and funding surrounding the Symonds Street memorial but had also already visited grave sites in Drury, Opotiki, Taupo and would be visiting Ngaruawāhia by the end of the month. ${ }^{120}$ But by June it became apparent that $£ 200$ would not be enough to erect 'a handsome and worthy' memorial on the conspicuous Symonds Street site. According to Statham, the committee approached the central government again to obtain the potential further funding that had been gestured. ${ }^{121}$

By December 1911, Carr Rollett stepped down from the Honorary secretary position of the League's Auckland branch and Statham was appointed in her place. ${ }^{122}$ In January of 1912 Statham wired Ward to follow up on the intimation of $£ 1000$ in funds for the memorial, suggesting that the proposed memorial was now looking like it could cost $£ 2000 .{ }^{123}$ Ward replied stating that $£ 500$ for the memorial project would be authorised immediately and that a further $£ 533$ would be given to the upkeep of those individual graves at Symonds Street and the other sites in the North Island that Statham had already been visiting. ${ }^{124}$ The League continued to raise public funds for the memorial project. On 24

\footnotetext{
116 Ibid.

117 Ibid.

118 'In the Memory of Our Old Soldiers', AS, 25 February 1911, p. 11.

${ }^{119}$ Hilda Carr Rollett, 'Report to the President and Members of the Victoria League', 6 March 1911, 'Early reports, minutes, etc.’, Box 43, NZMS, GGSC.

120 Ibid.

${ }^{121}$ Edith Statham to Under Secretary James Hislop, 6 September 1915.

${ }^{122}$ Edith Statham, 'Report to the President and Members of the Victoria League', 7 March 1912, NZMS 1244, Box 43, GGSC.

${ }^{123}$ Edith Statham to J.G. Ward, 12 January 1912, Ephemera (Loose), Boxes 1, 4, 14, 15, NZMS 1244, GGSC.

124 J.G. Ward to Edith Statham, 15 January 1912, Ephemera (Loose), Boxes 1, 4, 14, 15, NZMS 1244, GGSC.
} 
May 1912 or 'Empire Day', the League held a grand 'Empire Concert' at the town hall and placed an advertisement for subscriptions in the souvenir booklet that read; 'this Committee has the honour of collecting funds towards a memorial monument to all who died in bringing this fair Dominion into the imperial fold. ${ }^{125}$ In the annual report for the 1911-12 year Statham proudly reported this progress to the London headquarters of the League:

The Government has appointed the League to undertake the long neglected work of renovation of the soldiers' graves, and work, has now begun in earnest in this direction. Steps are also being taken in regard to the proposed memorial to be erected in the city to the memory of those who fell in the Waikato Wars. It is hoped to interest both old and young in this work, and instil some ideas of the history of New Zealand into their minds by means of meetings and lectures of a patriotic nature, bringing into prominence at them the incidents of the wars in New Zealand. ${ }^{126}$

This marked a key moment in Statham's work when, not only was she enacting her entitlement and duty to promoting empire through the memory of its fallen soldiers, but she was identifying knowledge of New Zealand's history in fostering this sense of patriotism.

The message was both of imperial loyalty and of local distinction. Which is perhaps why Ward's Liberal Government, would not only be willing to fund the League's memorialising work, but took particular interest in Statham herself. In March 1913, Statham received a personal letter from then Minister of Internal Affairs, Francis Bell, offering that she continue the grave renovation and memorialising work under government contract. ${ }^{127}$ As Statham recounted of this governmental interest in 1915:

Mr. Bell supposed that my wide experience as Hon. Secretary of the Care of Graves Committee of the [Victoria League] would be valuable, and I was pleased to accept the appointment, which I have the honour to hold ever since. ${ }^{128}$

Statham did indeed take up the position, but it would not be until August 1914 that she would leave the Victoria League and continue as the government inspector of old soldier graves. ${ }^{129}$ The remainder of this discussion pertains to the work Statham continued to do with the Victoria League, predominantly focusing on the Symonds Street memorial, before officially resigning as Honorary Secretary 18 months later to focus on the work as a government initiative.

\footnotetext{
125 'Souvenir Programme of Grand Empire Concert, 24 May 1912, Ephemera (Loose), Boxes 1, 4, 14, 15, NZMS 1244, GGSC, p. 25.

${ }^{126}$ Edith Statham, 'Victoria League of Auckland', Victoria League Tenth Annual Report 1911-12, (London: Victoria League, 1912), p. 60.

${ }^{127}$ Edith Statham to Under Secretary James Hislop, 6 September 1915, ACGO 8333, IA1, 1287, 7/4/2, ANZ.

${ }^{128}$ Ibid.

${ }^{129}$ Ibid.
} 
In June 1913, Statham reported that the government had finally raised the fund for the memorial to the $£ 1000$ they had intimated two years earlier. ${ }^{130}$ By July, Statham and the League published an advertisement in many of the main centre newspapers across New Zealand and Australia for memorial design proposals from the general public. The advertisement read:

A sum of $£ 1000$ has been promised by the Minister for Finance to the Victoria League of Auckland, to enable it to erect a memorial to commemorate the deeds of soldiers, and sailors who fell in the New Zealand Wars. Steps are now being taken by the League towards accomplishment of the idea which it has promoted for several years, its first concern being to secure an appropriate design for the memorial... Authors of designs will be free to suggest the material to be used in the construction of the memorial, but the cost must not exceed $£ 1000$. The author of the selected design will be entrusted with the carrying out of the work. The triangular reserve at the junction of Wakefield and Symonds Streets has been given to the League by the City Council as a site for the memorial, and about $£ 150$ has been subscribed in the city to meet contingent expenses. Designs are to be sent to the league not later than January $10[1914]{ }^{131}$

The advertisement was met with some opposition, one response came on 30 July from Henry Green who suggested that perhaps $£ 1000$ might be better put towards the Veteran Home funds along with a more economical option of putting a plaque to the war dead on the town hall. ${ }^{132}$ Statham personally responded to Green by pointing out that on the one hand the money had already been allocated for the specific purpose of a memorial. But on a deeper level she asserted:

We wish not only to honour the dead but to remind the living of the work they did for us so many years ago, and so we decided to erect the proposed memorial in a prominent position for this purpose... if we put a tablet on the Town Hall as you suggest, but few people, comparatively speaking, will ever see it, and by the same rule an addition to the Veteran's home, however necessary, would also fail to convey the idea to the people of Auckland because only those visiting the Home would ever know what had been done., ${ }^{133}$

Just as the soldiers had done their duty in serving empire on the battlefield, so too, it seemed, did Statham see it as her duty to ensure their sacrifice was remembered and would continue to be remembered by ensuring the memorial was in a prominent, public position.

\footnotetext{
${ }^{130}$ Edith Statham, 'Report to the Council', 24 June 1913, Box 43, NZMS 1244, GGSC.

131 'Maori War Heroes: Victoria League’s Memorial’, NZH, 19 July 1913, p. 8.

132 Henry Green to Edith Statham, 30 July 1913, ACGO 8333, IA1, 1287, 7/4/2, ANZ.

${ }^{133}$ Edith Statham to Henry Green, c. 4 August 1913, ACGO 8333, IA1, 1287, 7/4/2, ANZ.
} 
Statham was not alone in her hopes for a conspicuous monument. As Jock Phillips points out, before the government had raised its offer to the £1000, local architect John Park had offered a design that comprised three flights of stairs with a middle shaft and two figures of a 'native' kneeling before an imperial soldier, but this had been rejected by the council for not being conspicuous enough. ${ }^{134}$ With the new, more enticing funds available the League received about twenty competitive entries in the following six months. In the week following the competition's close in January of 1914, the League received word that a late entry from London was on its way in the mail. The design was by Thomas Eyre Macklin, who was also responsible for a memorial in

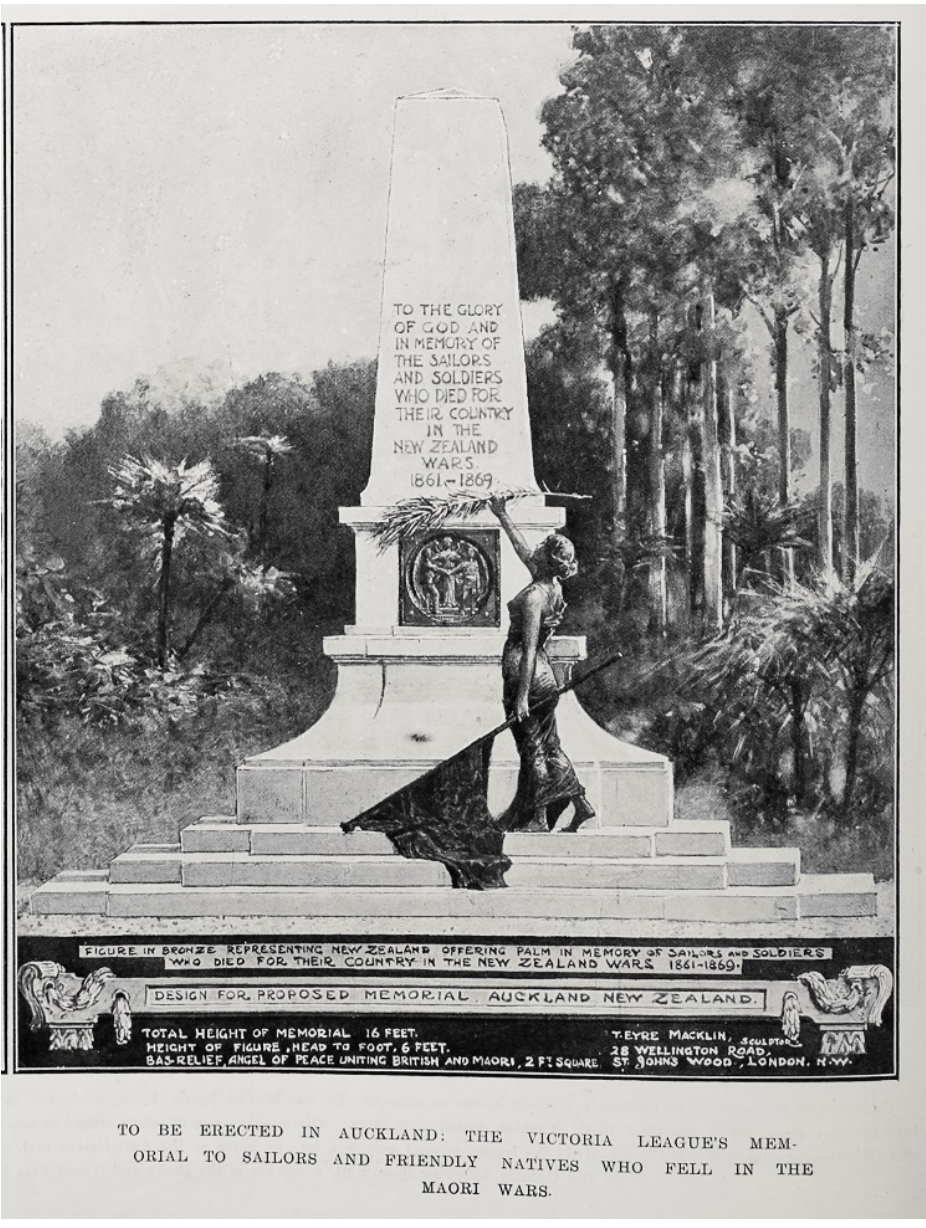

Fig. 3 - 'To Be Erected in Auckland', Auckland Weekly News, 18 June 1914, AWNS-19140618-40-4, Sir George Grey Special Collections, Auckland.

Newcastle-upon-Tyne to the British

Soldiers who fell during the South African war, featuring a tall obelisk with a winged victory figure at the top. ${ }^{135}$ In early June, Macklin's design of an obelisk and a draped female figure in bronze 'with an upraised palm branch in the right hand and the New Zealand flag drooped in the left hand', was officially selected by the committee that included the Auckland Mayor, and local architects and businessmen [see fig. 3]. ${ }^{136}$

The design proposal included a template inscription, that referred to 'the soldiers and sailors and friendly natives who fell in the New Zealand Wars (1861-1869). ${ }^{137}$ This date range had been the cause of complaint for a member of the public, to whom Statham responded by ensuring them that no inscription had been confirmed and that the one included in the design had merely been a suggestion of Macklin's and that he had been advised to alter it. ${ }^{138}$ As stipulated in the original advertisement, the

\footnotetext{
134 Phillips, To the Memory, p. 38.

135 'Personal Notes from London', AS, 16 January 1914, p. 8.

136 ‘A Triumphant Industry’, AS, 9 June 1914, p. 4; Phillips, To the Memory, p. 38.

137 'Maori War Memorial', NZH, 11 June 1914, p. 10.

${ }^{138}$ Ibid; Edith Statham, 'Maori War Memorial’, NZH, 16 June 1914, p. 10.
} 
selected designer of the monument was responsible for carrying out its construction. The $£ 1000$ was transferred to Macklin via the new high commissioner, Thomas Mackenzie, in London. ${ }^{139}$ Seeking an authority on the 'Maori Wars' and on 'Maori lore', Macklin then sought out Robley in August 1914 to draw up appropriate text for his monument. ${ }^{140}$ It is unclear whether Robley's contribution is the one that ultimately ended up on the memorial. Macklin's bronze sculpture had arrived in New Zealand alone in $1915 .{ }^{141}$ The inscription that did make it to the final product read:

In memory of the brave men belonging to the imperial and colonial forces and the friendly Maoris who gave their lives for the country during the New Zealand Wars 1845-1872. [see fig. 4]

The wording certainly echoed the dedication to Robley's Moko; or Maori Tattooing eighteen years earlier. ${ }^{142}$ According to Phillips, before this final inscription was fully approved by the government after Macklin's monument had arrived in 1915, the League had tried to have the wording tweaked to 'for country and Empire' which was ultimately denied. ${ }^{143}$ Statham formally resigned as Honorary Secretary

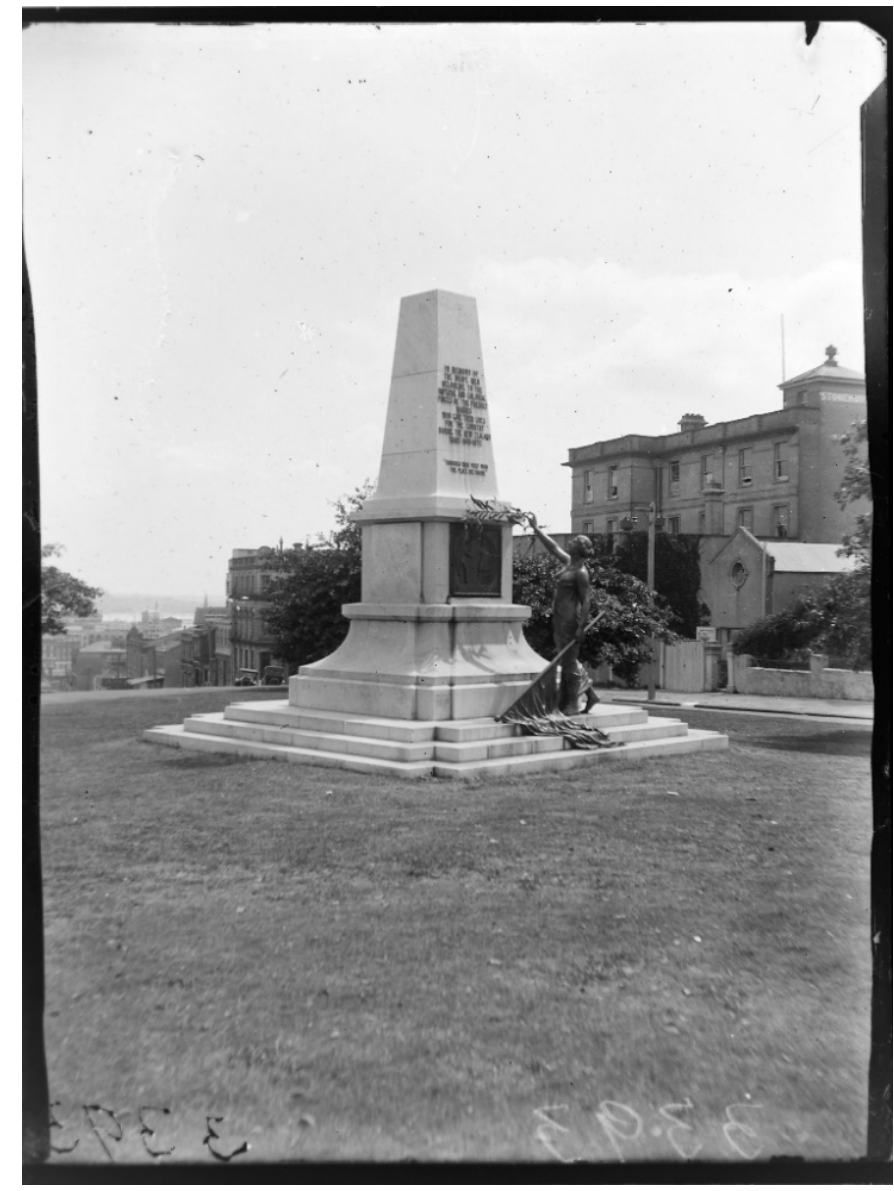

Fig. 4 - Left: James D. Richardson, 'War memorial on the corner of Wakefield and Symonds Street, Auckland', Ref. 4-3393, Sir George Grey Special Collections, Auckland. Right: Symonds Street memorial inscription, photo by author, 7 August 2020.

\footnotetext{
${ }^{139}$ NZH, 4 August 1914, p. 6.

140 Ibid.

${ }^{141}$ AS, 28 August 1919, p. 4.

142 Robley, Moko; or Maori Tattooing, p. iii.

143 Phillips, To the Memory, p. 38.
}

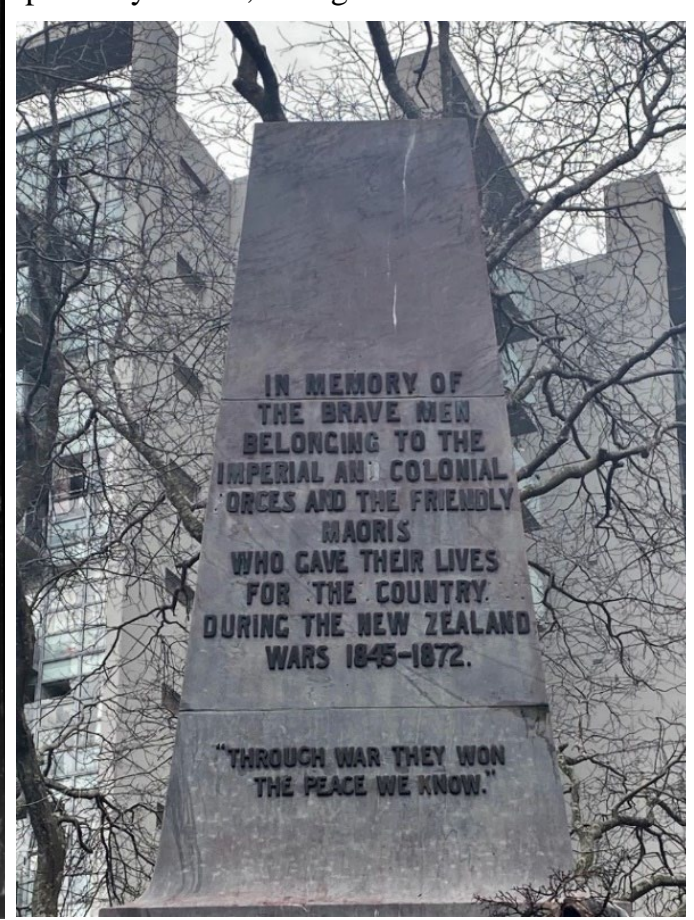


of the League in August 1914. After over a year of splitting her time between the League position and her government role focusing on the soldier graves, she would focus solely on the government initiative, which meant she was drawn away from the Symonds Street memorial project. ${ }^{144}$ The government had seen the value in her imperial soldier grave work from 1912. But as the country prepared to go to war for the empire again, her experience memorialising imperial soldiers who fought in distant battlefields away from the homeland, would take on a whole meaning as New Zealand prepared to join the battlefields of Europe.

Back in London, when he was not assisting Macklin with his inscription, Robley was also considering the onset of war and what that might mean for 'the land of the Maori' of his youth. After the rejection of his collection in 1906 and the sale to the American Museum of most of the collection in 1907, Robley tended to his wounds, sending a letter to Donne at the Department of Tourist and Health Resorts stating that he would not bother any more with any new offers for the remaining mokomokai. As Donne had suggested, it was not the right time. ${ }^{145}$ The rejection appeared to quieten Robley's interventionist approach to New Zealand's national artistic collections, but he continued to engage in ethnological study, particularly of pounamu and his collection of hei tiki, which he would eventually publish in his second study in $1915 .{ }^{146}$ But he also took the opportunity of his affiliation with New Zealand House in London to meet with with New Zealanders visiting the metropole, continuing to propagate a sense of Maoriland through his production of picture postcards. In Felicity Barnes' work looking at the relationship between New Zealand and the London metropole in the early decades of the twentieth century, Barnes acknowledged New Zealand House's earlier function to market New Zealand for tourism purposes. The primary point of her argument however was that in the early decades of the century, New Zealand House operations were geared towards New Zealand travellers, as the doorway that 'opened into the heart of the imperial metropolis.' ${ }^{147}$ It was an 'appropriation' of the centre that Barnes argues may look like pure nationalism but was also designed to foster a sense of home in the old imperial metropolis. ${ }^{148}$ It was a dynamic that encapsulated the congruency of imperial and nationalist identities in New Zealand at this time. In the period following the rejection of his collection, Robley had the opportunity to engage with far more New Zealanders in London than ever before. As Barnes argues, by 1912, New Zealand House had begun to 'sag' under the weight of New Zealand visitors and their needs. ${ }^{149}$

\footnotetext{
${ }^{144}$ Ibid.

${ }^{145}$ Horatio G. Robley, to Thomas E. Donne, c. 1908, MS-Papers-1387-13, ATL.

${ }^{146}$ Horatio Gordon Robley, Pounamu - Notes on New Zealand Greenstone, (London: T.J.S. Guilford \& Co., 1915).

${ }^{147}$ Barnes, p. 46.

148 Ibid.

${ }^{149}$ Ibid, p. 50.
} 
The picture postcard proved a popular form to relationships between individuals in New Zealand and Britain as two-way movements between Dominion and Metropolis increased. The picture postcard form had been in use in Europe since the 1870s from whence it developed from a medium primarily for business, to more personal uses. ${ }^{150}$ It was not until 1898 when the New Zealand government had allowed their personal use, and New Zealand's entry into the 1901 International Penny Post, that the postcard would become a mainstay of communication between those in New Zealand and those in the metropole. ${ }^{151}$ As Peter Gilderdale has demonstrated, the 'hands across the sea' postcard design, with its emblem of clasped hands, was a particularly potent demonstration of the relationship between newer settlers and those back home. ${ }^{152}$ Robley was prolific in creating picture postcards ever since he began collecting and sketching of Māori specimens towards the end of the nineteenthcentury. ${ }^{153}$ But as Robley's contributions to the medium suggests, the Edwardian picture postcard was also a means of circulating Māori imagery as a continuation of his creation of a New Zealand locale from London.

In late 1909, Robley sent a postcard to educationalist Henry Hill, that had the infamous image of Robley with his full collection of mokomokai mounted on the wall behind him. The reproduction of the image appeared rather amateurly done, with the image itself taking up only a third of the blank space, possibly further evidence that whether a sketch or photograph, Robley was producing these postcards himself. ${ }^{154}$ In another set of examples from 1913, Robley's collection of mokomokai again was the inspiration for a set of postcards which he had sent to a Mrs Craig Brown. ${ }^{155}$ Such postcard representations of the mokomokai appear as an attempt to have himself and the collection find some popular recognition in New Zealand despite being sold to the American museum in $1907 .{ }^{156}$ The reproduction of Māori imagery echoed the trends of artists and collectors in New Zealand. William F. Gordon was one prominent example, who was also making copious reproductions of his colonial war photographic portraits at the same time. ${ }^{157}$ A further two or three of Robley's postcards held at the Alexander Turnbull Library depicting hei tiki and carvings but are without a specified date, might also be attributed to this period as they also feature in Robley's publication on Pounamu that was published in $1915 .^{158}$

\footnotetext{
${ }^{150}$ Gilderdale, p. 5.

${ }^{151}$ Ibid.

152 Ibid, p. 6.

${ }^{153}$ Horatio Gordon Robley to Sir Walter Buller, c. 1897-1906, MS-Papers-1387-13, ATL.

${ }^{154}$ Horatio Gordon Robley to Henry Hill, c. December 1909, 'Inward correspondence - T F Cheeseman, W

Petrie, J Drummond and others', MS-Papers-0172-010, ATL.

${ }^{155}$ Horatio Gordon Robley to Ms. Craig Brown, c. 1913, 'Sketches', MS-Papers-0016-03, ATL.

${ }^{156}$ NZT, 14 November 1907, p. 4.

${ }^{157}$ Rebecca Rice, 'The ‘Gordon Collection' of Photographic Portraits Relating to the New Zealand Wars', NZJH, Vol. 52, No. 1, 2018, p. 51.

${ }^{158}$ Horatio Gordon Robley, 'Hei-tiki', E-280-017-1, ATL; Horatio Gordon Robley, 'Maori Carving’, E-280-

005, ATL.
} 
With the outbreak of war in 1914, Robley took the opportunity of the postcard form to suggest how Māori and the culture of Maoriland might look before New Zealand's troops saw any combat. In a postcard sent to Gordon in New Plymouth, Robley sketched a scene entitled 'The Maorilander's Greeting to Kaiser Bill' and featured a white dominion soldier holding what appears to be a mokomokai in the face of the scared looking Kaiser Wilhelm II of Germany [see fig. 5]. The image, somewhat like artist Trevor Lloyd's satirical renderings of both Māori and the culture of Maoriland, appeared to use humour to depict how the Dominion might deploy the scary or 'savage' trope to an imperial battlefield. ${ }^{159}$ Trevor Lloyd demonstrated a similar propagation of Māori involvement in a cartoon published in the Auckland Weekly News in September 1914 depicting Māori men in traditional attire which he entitled 'where is Te Kaiser?' ${ }^{160}$ But in 1914 Robley and Lloyd, would have had no idea of the brutal war to come, let alone the reality of how Dominion Soldiers, including the Māori contigent, would experience it. ${ }^{161}$ Robley would continue to provide visitors to London with picture postcards with tiki and Māori carvings, but this time the visitors would be some 60,000 New Zealand troops who would pass through London over the next four years. ${ }^{162}$ Robley, later recalling this time to Donne, suggested that many of these travelling soldiers 'liked a reminder of home, small pictures of a tiki they could post off with their letters there. ${ }^{363}$ By the time the war had ended in 1918, the nature of Robley's engagement with New Zealand would change once again, from metropolitan donor and expert commentator to a key protagonist in its founding narrative.

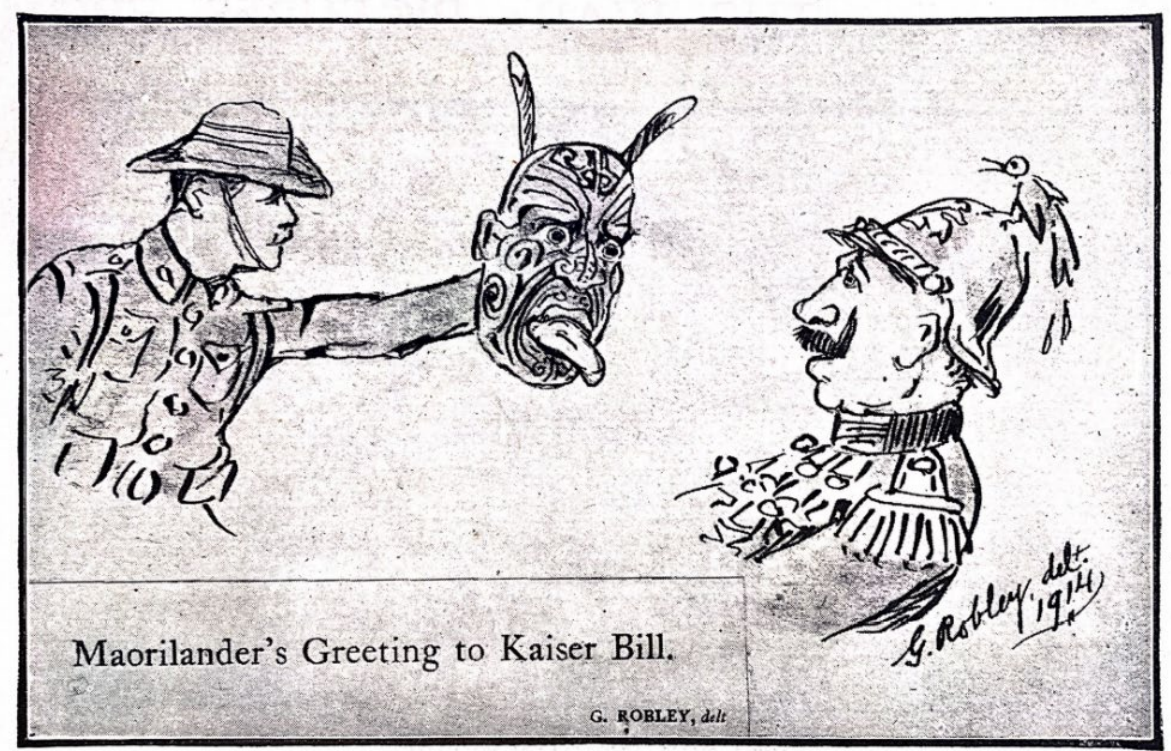

MAORILAND'S GREETING TO KAISER BILL.

This postcard sketch, which is the work of General G. Robley, late 68th Regiment, is reproduced by courtesy of Mr W. F. Gordon, of New Plymouth.
Fig. 5 - Horatio Gordon Robley, 'Maorilander's Greeting to Kaiser Bill', 1914, Fildes, MSS 1507, Folder 2, J.C. Beaglehole Room, Victoria University of Wellington.

\footnotetext{
159 Blackley, Galleries of Maoriland, 190-192.

${ }^{160}$ Auckland Weekly News, 24 September 1914, p. 46, as cited in Loveridge, “'Soldiers and Shirkers”, p. 67.

${ }^{161}$ Walker, “'Descendants of a Warrior Race’, p. 5; Loveridge, “Soldiers and Shirkers”, p. 67.

162 Anna Maguire, 'Looking for Home? New Zealand Soldiers Visiting London During the First World War', The London Journal, Vol. 41, No. 3, 2016, p. 282.

163 Horatio Gordon Robley to Thomas E. Donne, c. 1921, MS-Papers-1387-14, ATL.
} 


\section{Chapter Three \\ 'Propelled by Change to Organise the Past': ${ }^{1}$ Perfecting the Narrative of Colonial Memory \\ 1914-1923}

Less than one month after war had been declared in August 1914, New Zealand forces led by Colonel Robert Logan arrived at the beaches of German Samoa, capturing the colony in a rather jingoistic manner, with little opposition from the Germans. ${ }^{2}$ But nothing could quite prepare the colony for the bloodshed that would be experienced eight months later, when on 25 April 1915 Dominion soldiers landed at Gallipoli in Turkey. By the end of the campaign in late 1915, 2779 or one sixth of those Dominion soldiers had died. This included crippling losses to the 500 strong Māori contingent who by the time of evacuation had only 134 men left standing. ${ }^{3}$ The participation of the contingent had initially been promoted by the Māori MPs Peter Buck, Āpirana Ngata, Maui Pomare and Taare Parata, who saw the an opportunity for advancing Māori interests in the anglo-world's hero-worship of men sent to fight on battlefields. ${ }^{4}$ On one level this chapter explores all the ways in which the Māori MPs were correct to believe this about war and its narratives. In a letter to Elsdon Best that appeared to be from 1915, Robley reported that he had 'got a censor passed letter from a friend Dardanelles way, so learnt of the fine AU and NZ troops in a confidential way, the casualty lists at the Government Offices I see posted up - what a toll NZ is enduring. ${ }^{5}$

While the war raged on the Western front, Edith Statham, James Cowan and eventually Robley continued their work on the colonial past, now in the context of a new and urgent call to arms of a different kind, that would come to define nation as well as empire. This chapter concerns the period of substantial crossover in the historical work of Statham, Cowan and Robley. It begins with the flurry of $50^{\text {th }}$ anniversaries of the New Zealand Wars in 1914 and ends with the publication of Cowan's second volume of his 'national history of the wars in New Zealand' or The New Zealand Wars, in $1923 .{ }^{6}$ How did the three history-makers frame their respective histories of the colonial period during this period of enhanced duty to empire, tremendous loss and new understandings of nationhood? Who was reckoned

\footnotetext{
${ }^{1}$ Pierre Nora, 'Between Memory and History: Les Lieux de Mémoire’, Representations, No. 26, Spring 1989, p. 8.

${ }^{2}$ Ian McGibbon, 'New Zealand’s First Conquest', New Zealand International Review, Vol. 39, No. 1, 2014, p. 18.

${ }^{3}$ Walker, “Descendants of a Warrior Race’”, p. 5.

${ }^{4}$ Ibid, p. 12.

${ }^{5}$ Horatio Gordon Robley to Elsdon Best, c. 1915, 'Inward Correspondence - H.G. Robley', MS-Papers-007205A, ATL.

${ }^{6}$ James Cowan to George W. Russell, 28 November 1917, ACGO 8333, Series IA1, 1280, 4/2/13, ANZ.
} 
'historical' by Cowan, Statham and Robley and what did this say about the function of history at this time? How did military sacrifice, empire and nation provoke new forms of public memory?

In one respect, the coalescing historical work of Cowan, Statham and Robley discussed in this chapter advances the dichotomous character of belonging of their work delineated in the previous chapter. It is during this 1914-23 era in which the three history-makers most embody what Kathryn Hunter describes as the 'entangled knot of belonging' to both a nation and an empire. ${ }^{7}$ Their histories during this time continue to naturalise the settlement of the Pākehā population at the dawn of a new age of nationhood, along with validating a sense of imperial citizenship amidst a brutal war fought in the name of empire. Furthermore, the intense martial focus of this 1914-23 period would have deep implications for how the history-makers would frame the conflicts of the colonial past. In his argument of the cultural colonisation by Pākehā intellectuals in the early twentieth century, Peter Gibbons explains this as a dialectic habit of early New Zealand historians: 'with the development of the nation regarded as the primary narrative, the colonial period becomes a precursor to the era of nationhood, and colonisation, inaugurating the colonial period, becomes an episode in the early history of the nation.' ${ }^{8}$ The martial nature of this nation-shaped narrative also holds particular considerations for gender. As Stephen Loveridge has explored in his work on masculinity and modernity in the Great War, one of the most popular narratives of the Dominion experience was that Pākehā and Māori men, fighting together as comrades, had developed a sense of martial, modernist brotherhood. ${ }^{9}$ This notion of a cross-cultural fraternity for New Zealand touched upon the work of all three history-makers and would influence the ways in which they would position the New Zealand Wars when Māori and Pākehā were opposing combatants. To understand the unifying nature of a narrative relationship between past antagonism and present comraderie Benedict Anderson's explanation of fratricide, that is, the killing of one's own brother, is relevant: '[fratricide] reflects a deep reshaping of the imagination of which the state was barely conscious, and over which it had, and still has, only exiguous control... the imagining of fraternity, without the reassurance of fratricide, cannot be born. ${ }^{10}$ As this chapter illustrates, the nascent histories of Cowan, Statham and Robley demonstrate the particularities of the Great War present for both remembering the past and informing collective identity for the future.

This discussion begins by revisiting Statham in 1913, after she was appointed as inspector of old soldier graves for the Department of Internal Affairs, focusing on the neglected gravesites around the country, erecting monuments wherever individual graves could not be identified. The process for Statham was not just about conducting her imperial duty of remembering imperial soldier sacrifice but also preserving 'the only history' that New Zealand had. ${ }^{11}$ Following Statham's memorialising work,

\footnotetext{
${ }^{7}$ Hunter, 'National and Imperial Belonging in Wartime’, p. 32.

${ }^{8}$ Gibbons, p. 6.

${ }^{9}$ Loveridge, “'Soldiers and Shirkers', p. 68.

${ }^{10}$ Anderson, pp. 201-202.

11 Phillips, To the Memory, p. 36.
} 
the discussion leads into the flurry of $50^{\text {th }}$ anniversaries of the battles in New Zealand in 1914, involving all three history-makers to some degree. The discussion then analyses Statham's deliberations over who was considered 'historical' and therefore worthy of memorialisation. The Symonds Street memorial had provided the simplest template for how to memorialise soldiers from the New Zealand Wars within an imperialist agenda: that was, everyone who fought for the empire against those Māori designated as 'rebels.' But as this chapter demonstrates Statham's memorialising of the New Zealand War period would force her to reconcile the position of all Māori in her imperial vision of the New Zealand past.

The next part of the chapter considers the moment when Statham and Cowan came directly in contact as they both produced historical work for the Department of Internal Affairs. At the tail end of the Great War Cowan, along with new inspector of recruiting services Colonel Thomas Porter, began lobbying the government for Cowan to write a national history of the wars in New Zealand. By 1918 the government had agreed to pay Cowan for the history work and he began traveling the country gathering veteran accounts. As part of his contract Cowan was also tasked with gathering material for the new National Historical Collection, a stipulation of the Science and Art Act 1913, focusing on 'native historical and other information.' ${ }^{12}$ Robley continued to produce New Zealand history during this period. Robley's watercolours of the colonial war period finally went on display at the Dominion Museum in 1914. Then, in 1918, he caught wind of Cowan's national history project and began a series of correspondence with those in New Zealand about his own experiences and their value to New Zealand memory. The chapter concludes by exploring the final publication of Cowan's two volumes of The New Zealand Wars in relation to Statham and Robley's work; what memories of the colonial period the three had collectively produced and what this suggested about what they envisioned for New Zealand society in the post-war age.

After accepting the offer of employment from Minister of Internal Affairs, Francis Bell in March 1913, Edith Statham began her role as the official 'inspector of old soldier graves' in Auckland. ${ }^{13}$ In the position Statham worked directly to Under-Secretary James Hislop, who was the recipient of Statham's exhaustive monthly reports on the work. ${ }^{14}$ As was the case with the Symonds Street memorial, it became increasingly apparent to Statham that preserving the memory of those who served the empire within New Zealand was not just about scoping out strictly British gravesites, but also recognising the loyalty of those kūpapa Māori who fought for the Crown. While she worked to refurbish the graves of European soldiers in the Symonds Street cemetery, Statham began refurbishing graves in the wider Auckland region, which initially did not challenge that clear line of imperial distinction

\footnotetext{
${ }^{12}$ Colonel Thomas W. Porter, Memorandum for the Governor General, 21 January 1918, ACGO 8333, IA1, 1280, 4/2/13, ANZ.

${ }^{13}$ Edith Statham to James Hislop, 6 September 1915, ACGO 8333, IA1, 1287, 7/4/2, ANZ.

${ }^{14}$ Phillips, To the Memory, p. 40.
} 
between 'friendly' and 'rebel.' Two months after Statham accepted the government position, she reported visiting and assessing the gravesite of Ngā Puhi leader Eruera Patuone at the Church of England cemetery in Devonport. Statham noted in the government logbook in May 1913 that $£ 10$ had been paid to McNab and Mason 'for renovating the grave of Eru Patuone, Maori War Veteran.'15 Patuone, who had a history of alliance with the British, had been predominantly involved in the signing of the Treaty of Waitangi and had also developed an advisory relationship with Governor George Grey before 1865, during the Waikato Wars. ${ }^{16}$ Statham's restoration of Patuone's grave was thus a relatively uncomplicated extension of the Victoria League's commemorative work for the imperial cause.

But as Statham would quickly realise her new governmental role would bring about a whole new set of challenges particularly once she left the context of Auckland. On one of her first trips out of the city in June 1913, Statham travelled to Te Awamutu to inspect the cemetery at the local St John's

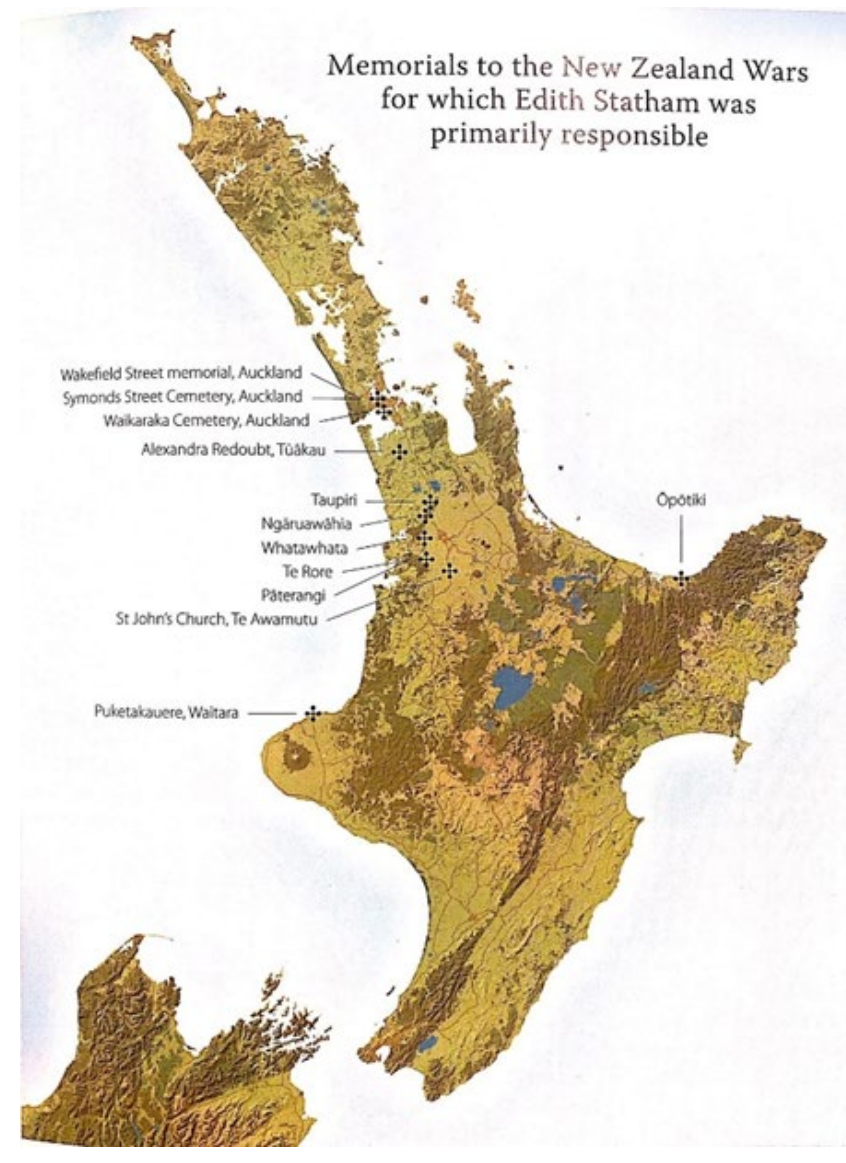

Fig. 6 - Jock Phillips, To the Memory: New Zealand's War Memorials, (Nelson: Potton and Burton, 2016), p. 37.
Church. ${ }^{17}$ On the property was a shared monument to the British troops killed at the battles of Rangiaowhia, Hairini and Ōrākau that had been erected in 1888 at government expense but the site also included six unmarked graves believed to be kūpapa Māori. ${ }^{18}$ Like the graves she had refurbished back in Auckland, as well as the other 'Māori War' memorials she had begun work on such as that at Whatawhata, Ngāruawāhia, Te Rore, Pāterangi and Opōtiki, this extension of imperial memory would be easy; these men had fought for the Crown. However, after commissioning the local vicar, F.W. Clarke, to research and write an inscription for the men, he informed Statham that the men were not kūpapa; they were Kīngitanga fighters who had been taken captive by the British at Hairini and Ōrākau and who had subsequently died of

\footnotetext{
${ }^{15}$ Edith Statham, May 1913, 'Folder of notes and papers relating to Maori War and Historical Cemeteries, Graves and Memorials’, ACGO 8398, Series IA 76, Box 1, Item 1, ANZ.

${ }^{16}$ Angela Ballara. 'Patuone, Eruera Maihi', DNZB, Te Ara, 1990, updated 2010;

https://teara.govt.nz/en/biographies/1p12/patuone-eruera-maihi; accessed 3 July 2021.

${ }_{17}$ Phillips, To the Memory, p. 41.

${ }^{18}$ Vincent O’Malley, “'Recording the Incident with a Monument”: The Waikato War in Historical Memory', JNZS, Vol. 19, 2015, p. 83.
} 
their wounds. ${ }^{19}$ Clarke suggested that they move forward and commemorate the men anyway for they had died in recognisably heroic circumstances; laying down their lives for their cause. Statham's immediate superior James Hislop agreed to the inscription that read 'Erected by the New Zealand Government in Memory of the Maori warriors who fell in the battles of Hairini and Orakau 1864'. But when Clarke changed 'warriors' to 'heroes' at the last minute, Statham felt that such a characterisation went too far, and she did not approve. ${ }^{20}$

Soon thereafter another monument was erected under similar circumstances at Te Ranga in Tauranga, which brought the activities of Statham and Robley together again. Despite their indirect collaboration on the Victoria League's Symonds Street memorial, Robley took to the task of acknowledging opposing Māori more readily than Statham. In recalling his experiences at Te Ranga to Horace Fildes in 1919, Robley described the burial of 'the one hundred and eight Maori dead' upon the end of the fighting in 1864. The men, including Rawiri Puhirake, had been buried within a Christian service conducted by Archdeacon Brown, a scene which Robley ended by proclaiming 'and so sepulchered in such a tomb dost lie, that kings for such a tomb would wish to die. ${ }^{21}$ Such a claim that Māori innately expressed and shared in the romantic belief of a good, worthy heroic death, would come to be a part of the 'Maori Amor Patriae' that Cowan expanded upon in his work. ${ }^{22}$ But for Robley, who had spent the last twenty years engaged in conversations about the ancient Māori past and its importance to New Zealand's national character, the prospect of giving the Māori opposition a heroes' memorial was far less confronting than it might have been for Statham.

On 15 April 1912, the Bay of Plenty Times reported that 'a movement was afoot amongst the Natives of the Tauranga district' to erect a monument over the grave of Rawiri, with the intention to approach the Native Minister to assist with funding. ${ }^{23}$ The article also mentioned that 'General Robley, who now resides in England' intimated his willingness to assist by collection of subscriptions 'in the Old Country. ${ }^{24}$ Two months later, a gathering of Māori either descended from Rawiri or having fought alongside him met with local Pākehā veterans and politicians to discuss the project. The article stated that Puhirake was worthy of a memorial because of his 'abandonement of the old-time savageries of warfare, and his strict orders for the humane treatment of the wounded and prisoners, and for noninterference with unarmed persons helped to uplift the Maori character. ${ }^{25}$ A letter from Robley was read out expressing his support for the monument, followed up by a statement from John C. Adams

\footnotetext{
${ }^{19}$ Ibid.

${ }^{20}$ Phillips, To the Memory, p. 41.

${ }^{21}$ Fildes, 'Major General H. Gordon Robley: Soldier and Artist', 1921, Fildes MSS 1507, JCBR, p. 77.

22 James Cowan, The New Zealand Wars: A History of the Maori Campaigns and the Pioneering Period, Vol. II, $3^{\text {rd }}$ ed. (Wellington: Govt Printer, 1983), p. 1.

${ }^{23}$ Bay of Plenty Times (BPT), 15 April 1912, p. 4.

24 Ibid.

25 'The Gate Pa Recalled: An Interesting Gathering’, BPT, 19 June 1912, p. 5.
} 
who was also present, pointing out that 'some time back’ Robley had already committed $£ 5$ 6s to the cause. $^{26}$

The monument was unveiled on the anniversary of the battle, 21 June 1914, with a ceremony that was poised as a commemoration of the honourable conduct on both sides with a sense of mutual respect. ${ }^{27}$ The inscription upon the monument followed that sentiment from the initial gathering about Rawiri's rejection of his authentic ‘old-time savageries' and ended on a romantic statement of supposed 'post-colonial peace': ${ }^{28}$

The seed of bitter feelings between the two races thus sown in the battlefield, has since borne ample fruit. Disaffection has since given place to loyalty and hostility to friendship. British and Maoris now living together as one people. ${ }^{29}$

The sentiment matched Robley's own perception of the Tauranga wars and subsequent events, particularly in his relationship with Hori Ngatai of Ngāi te Rangi who he described as 'a fine specimen of his race, tall and straight, with clear cut intelligent features... [a] patriarchal chief.' ${ }^{30}$ When Robley later recounted his friendship with Ngatai he made sure to include examples of 'maimai aroha' between the two. This included Ngatai's 1901 visit to London where he gave Robley a pounamu ear pendant, in remembrance of the days they fought and their 'subsequent friendship., 31

The ceremony commemorating both sides of the battle was a far cry from the tension that Statham had felt over the inappropriate use of the term 'hero' for Māori opponents. But by the time Rāwiri's Te Ranga monument was unveiled in June 1914, not only was Statham present at the ceremony, six weeks later she was suggesting (though without success) that another monument to the greater collective of the Te Ranga opposition be erected. ${ }^{32}$ While Robley had been collaborating on the Tauranga monument from afar, Statham's focus had shifted towards the battle site of Ōrākau 'where the last shot was fired in the Waikato War. ${ }^{33}$ On 20 November 1913, Statham reported to Hislop that Hamilton members of the Victoria League had sought her advice on collecting subscriptions for a monument on the site of the battle, just southeast of the Kihikihi township. ${ }^{34}$ The monument had been in development since 1911 and by the time Statham was made aware of the matter all that was left was to finalise the inscription. ${ }^{35} \mathrm{Up}$ until that point, the monument had primarily been under the jurisdiction

\footnotetext{
26 Ibid.

${ }^{27}$ Macdonald, 'The First World War and the making of Colonial Memory', p. 25.

${ }^{28}$ Brendan Hokowhitu and Tiffany Page, 'Post-Colonial Peace', Junctures, Vol. 14, 2011, p. 14.

${ }^{29}$ Phillips, To the Memory, p. 43.

${ }^{30}$ Fildes, 'Major General H. Gordon Robley: Soldier and Artist', 1921, Fildes MSS 1507, JCBR, p. 81-82.

${ }^{31}$ Ibid.

32 Phillips, To the Memory, p. 44.

${ }^{33}$ Edith Statham to James Hislop, 20 November 1913, 'War Graves - Orakau’, ACGO 8333, IA1, Box 1292, Record 7/4/38, ANZ.

34 Ibid.

35 Phillips, To the Memory, p. 44.
} 
of a group of local Pākehā who had set up a jubilee committee in preparation for the 50th anniversary of the battle. The committee was chaired by Hamilton architect, F. Ernest Smith and had appointed J.W. Ellis to correspond with local iwi about the upcoming anniversary, perhaps with the cross-culturual collaboration of the gatherings prior to Te Ranga in mind. ${ }^{36}$ On 26 February, Ellis sent out a flyer in both English and te reo to 'the Maori tribes who fought against us in the Waikato War', where he stipulated the agenda for commemorating the battle:

We Europeans have always considered that defence of Orakau as the grandest fight made by the Maoris... [we] are trying to make the unveiling of the Orakau monument on the Jubilee of this grand fight worthy of this great occasion, and we want you Maoris to worthily represent the brave men who fought and died there... That we Europeans are always ready to appreciate a gallant foe is shown from the following extract from General Cameron's despatch re the Orakau battle... "It is impossible not to admire the heroic courage and devotion of Maoris [sic] in defending themselves for so long against overwhelming numbers...”37

In light of this, the committee proposed that the unveiling would occur on the first of April, the date of the 'splendid defence made by the Maoris [sic]' rather than the day the fighting subsided. ${ }^{38}$ Along with ensuring that a worthy inscription of the two recognisable leaders of the opposing forces, General Cameron and Rewi Maniapoto would be placed on either side of the monument in time for the Jubilee ceremony two months later. ${ }^{39}$ The committee appealed directly to the government for further funding in order to complete this inscription in time, which was approved by Hislop on 13 March and hastily completed mere days before the event. ${ }^{40}$ The committee, in an effort to cement the unveiling ceremony as a celebration of Rewi Maniapoto at Ōrākau, distributed a biographical pamphlet about the chief who personified the romantic portrayal of the defence with his 'brave words' 'ka whawhai tonu matou, Ake! Ake! Ake!' ${ }^{41}$ The pamphlet was finished off with Ellis' claim of confidence that 'Kingite Maoris' would support his 'contention that Rewi Maniapoto was a true and brave leader of his people. ${ }^{42}$ However, when the commemorations began on the first of April, there was a small number of Ngāti Maniapoto

\footnotetext{
${ }^{36}$ F. Ernest Smith to James Hislop, 18 March 1914, ACGO 8333, IA1, 1292, 7/4/38, ANZ [signs off as chairman]; J.W. Ellis, 'To the Maori Tribes Who Fought Against Us in the Waikato War', 26 February 1914, ACGO 8333, IA1, 1292, 7/4/38, ANZ.

${ }^{37}$ Ibid.

${ }^{38}$ Ibid.

${ }^{39}$ Ibid.

${ }^{40}$ James Hislop to F. Ernest Smith, 13 March 1914, James Hislop to F. Ernest Smith, 25 March 1914, ACGO 8333, IA1, 1292, 7/4/38, ANZ.

${ }^{41}$ J.W. Ellis, 'Rewi Maniapoto at Orakau and Rewi Maniapoto "The Fighter"', (Hamilton: Argus Print, 1914), ACGO 8333, IA1, 1292, 7/4/38, ANZ.

${ }^{42}$ Ibid.
} 
veterans and descendants, but not a Kīngitanga leader in sight. ${ }^{43}$ How the Kingitanga felt about Rewi was beside the point, the 1914 commemoration it seemed, ultimately served a Pākehā purpose.

Statham, who was present at the service became much more involved in the months following the Jubilee. Through a series of correspondence with Hari Wahanui of Ngāti Maniapoto and other interested parties, Statham had by June 1914, been alerted to the fact that only the Māori dead remained on the Ōrākau site, and the main road that had been established nearby cut right through where the old pā site had been. ${ }^{44}$ This appeared to have a profound impact on Statham. From the moment she began her imperial soldier work the location of the dead was of utmost importance. It is why she and the Auckland branch of the Victoria League began the work in the first

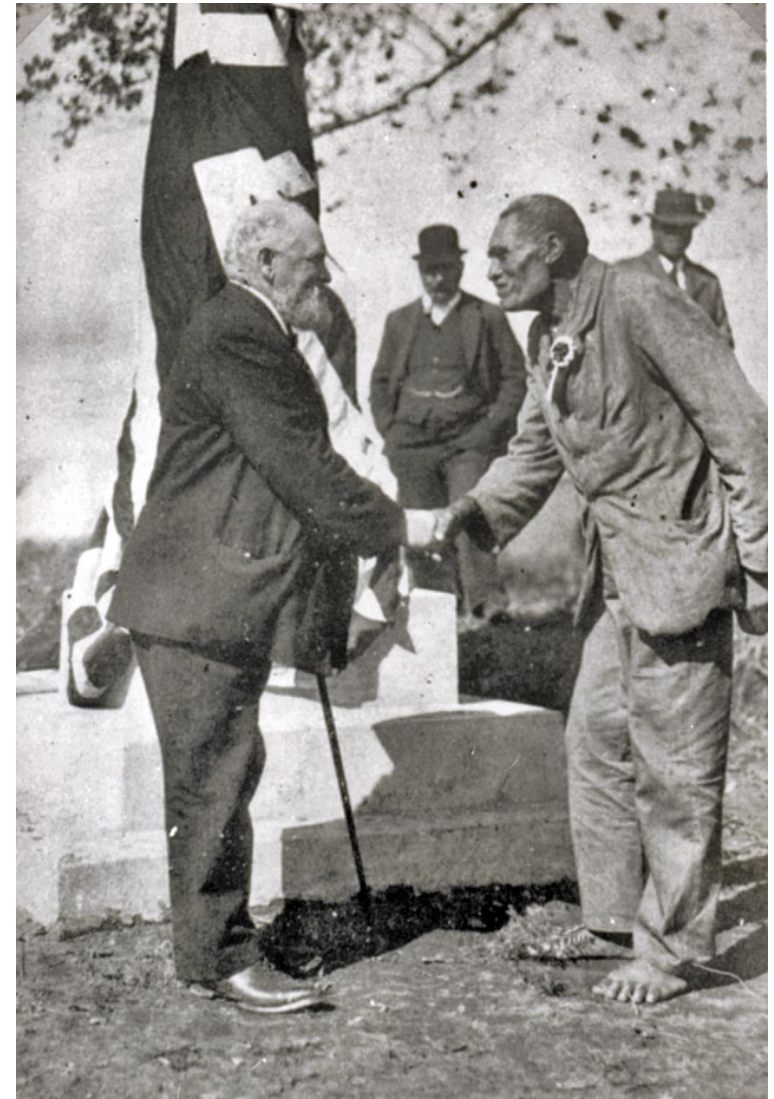

Fig. 7 - James Adam Capper and Hekeria Te Rangi, 14 April 1914, Ref. PH1497, Te Awamutu Museum, Te Awamutu. place. The League had facilitated the marking of burial sites and remembrance of fallen soldiers in the distant battlefields of South Africa, and in recognition of their proximity to those fallen imperial soldiers in New Zealand the Auckland branch had taken it upon themselves to ensure that those graves were marked and memorable. By this point, having been at the Ōrākau commemoration, Statham was starting to see the commemoration of opposing Māori as something that could be done in a way that did not contradict imperial allegiances. That perhaps in marking the spot of certain Māori combatants Statham might continue to exercise imperial duty, while also incorporating an emphasis on the national locale depicting its history.

Statham attempted for two years to get fallen Māori at Ōākau their own monument. But after being denied by the government as Phillips notes, due to 'many months of a costly war', she modified her approach to focus just on elaborating the inscription on the memorial that already stood. ${ }^{45}$ In March 1916 she approached member of the New Zealand Veteran's Association Henry Walton to obtain an

\footnotetext{
${ }^{43}$ Macdonald, 'The First World War and the making of Colonial Memory', p. 22; Phillips, To the Memory, p. 44.

${ }^{44}$ Edith Statham to James Hislop, 25 June 1914, ACGO 8333, IA1, 1292, 7/4/38, ANZ.

${ }^{45}$ Phillips, To the Memory, p. 45.
} 
inscription about 'who Rewi was and what he did. ${ }^{46}$ Walton was able to obtain a passage about Rewi for the inscription in December of that year from 'Te Heu Heu' who he described as 'one of the biggest chiefs on this island. ${ }^{47}$ Presumably Walton was referring to a member of the Te Heuheu family of Ngāti Tūwharetoa, a neighbouring iwi whose lands once were a part of the nineteenth-century rohe potae. ${ }^{48}$ Statham requested a translation of the text which read:

Rewi Maniapoto was one of the highest chiefs of Ngati-Maniapoto and Ngati-Raukawa. He was upholder of the Kingdom of Potatau Te Wherowhero and Tāwhiao, and at the time of the war waged by the Pakeha race against the Maori King, he fought in the war on the side of the Maori King, with the result that he was defeated here at Orakau, his tribe subdued, and his lands taken by conquest. ${ }^{49}$

In a letter to Hislop in January 1917, Statham expressed her disapproval; 'I do not quite like it, as it does not set forth the main fact that I was anxious to give publicity to viz,. that Rewi was the Chief commanding the Maori troops and made such a gallant defence against our men. ${ }^{50}$ Herein lies the crux of Statham's acceptance of Māori into her commemorative role; Māori would only be commemorated as long as their personal attributes reflected those of the dutiful imperial soldier or citizen.

Statham had begun the work with a focus on the soldiers and battlefields of the colonial period, but as the work continued she appeared to realise the power she had unleashed in the memorialising work when questions came about alternative figures of the past. In her first report as secretary of the Auckland branch of the Victoria League, Statham had made mention of the importance of 'instilling some ideas of the history of New Zealand' into the minds of both the 'old and the young. ${ }^{51}$ But at that point she still considered that 'patriotic' concept as inextricably linked with 'bringing into prominence at them [sic] incidents of the wars in New Zealand. ${ }^{52}$ Four years later, this attitude of Statham's appeared largely unchanged when she remarked to Hislop in January 1916 that the old soldier cemeteries were 'all the history that we have in N.Z. ${ }^{53}$ As time went on, Statham's concept of history was beginning to extend beyond just martial engagements. In September 1916 she reported that she had

\footnotetext{
${ }^{46}$ Edith Statham to Henry Walton, 16 March 1916, ACGO 8333, IA1, 1292, 7/4/38, ANZ; 'Death of a Veteran, Dominion, 21 August 1920, p. 6.

${ }^{47}$ Henry Walton to Edith Statham, 28 December 1916, ACGO 8333, IA1, 1292, 7/4/38, ANZ.

${ }^{48}$ Martin Wikaira, 'Ngāti Tūwharetoa - Lands and people', Te Ara, 2005, updated 2017; http://www.TeAra.govt.nz/en/ngati-tuwharetoa/page-1; accessed 3 July 2021.

49 'Translation', ACGO 8333, IA1, 1292, 7/4/38, ANZ.

${ }^{50}$ Edith Statham to James Hislop, 15 January 1917, ACGO 8333, IA1, 1292, 7/4/38, ANZ.

${ }^{51}$ Edith Statham, 'Victoria League of Auckland', The Victoria League Tenth Annual Report, 1911-1912, (2

Millbank House, Westminster, London S.W., 1911), p. 60.

52 Ibid.

53 Edith Statham to James Hislop, (recieved) 12 January 1916, 'War Graves - Rangiriri’, ACGO 8333, Series IA1, Box 1289, Record 7/4/20, ANZ.
} 
hopes to devote more attention to the 'branch of work' arranging for the care and attention to the 'various historical places of the Dominion.' 54

By 1917, Statham appeared to be presented with that kind of opportunity when on 8 January a bush fire broke out on Taupiri mountain, destroying the grave marking of King Tāwhiao. Statham, seeing the news of the bush fire reported in the New Zealand Herald, cut out the article and attached it to a letter to James Hislop that read: 'Sir, the enclosed cutting from the Auckland Herald appeared a week or two ago, and I forgot to send it on to you until now, does the matter affect the Department in any way, that is, is the grave of the Maori King reckoned historical? ${ }^{55}$ Hislop took Statham's enquiry to the Director of the Dominion Museum, Dr James Allen Thomson. Thomson, then took the question of the 'historical position of King Tawhiao' to Elsdon Best who replied with the following:

Tawhiao was the son of Potatau Te Wherowhero, a Waikato chief of high standing in the last century... He was an important man from the Maori point of view, but was not very much in contact with Eurpoeans, except during his trip to England. From our point of view Tawhiao occupied a middle position; he was neither an ally, not yet a bitter relentless enemy. Hence he might be classed with Te Whiti. Under the circumstances, it would seem correct to describe Tawhiao as a historical person and it would be a graceful act to treat his grave as a historical grave. There is, however, a political aspect viz. that the "King" movement is still extant and is influencing the attitude of Waikato natives towards recruiting. [My emphasis $]^{56}$

Hislop forwarded Best's statement to Statham, concurring with it by stating that no action be taken by Statham 'at least until the war is over.' ${ }^{57}$ Statham, appearing slightly relieved at the response, replied 'I certainly think with you that we should not take any steps to renovate his grave, at all events until we are asked to do so. ${ }^{58}$ As this correspondence demonstrated, defining New Zealand's 'historical' figures was inextricable from the Great War context with which their incorporation was being debated. Te Puea Herangi and Waikato-Tainui had been in staunch opposition against conscription because of the invasion and raupatu in the Waikato that Statham had been commemorating. ${ }^{59}$ Statham appeared tentative in her government role here, almost in recognition that the 'memory' of those battles for Waikato-Tainui was not a distant bell toll but a constant, lived reality.

In October 1917, Statham was presented with a decidedly less difficult figure for her to incorporate into the historical definition, when she was approached by Major F. Newcombe about the

\footnotetext{
${ }^{54}$ Edith Statham to James Hislop, (recieved) 23 September 1916, ACGO 8333, IA1, 1287, 7/4/2, ANZ.

55 Edith Statham to James Hislop, 22 January 1917, 'War Graves - King Tāwhiao', ACGO 8333, IA1, Box 1294, Record 7/4/69, ANZ.

${ }^{56}$ Elsdon Best, quoted by James A. Thompson to James Hislop, 27 January 1917, ACGO 8333, IA1, 1294, 7/4/69, ANZ.

${ }^{57}$ James Hislop to Edith Statham, 14 February 1917, ACGO 8333, IA1, 1294, 7/4/69, ANZ.

58 Edith Statham to James Hislop, 20 February 1917, ACGO 8333, IA1, 1294, 7/4/69, ANZ.

${ }^{59}$ Michael King, Te Puea: A Biography, Rev. Ed. (Auckland: Hodder and Stouton, 1978), pp. 77-78.
} 


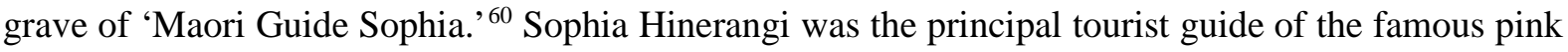
and white terraces at Lake Rotomahana, who, following their destruction in the 1886 Tarawera eruption, had continued her career as a guide at Whakarewarewa near Rotorua until her death in December 1911. ${ }^{61}$ Newcombe had asked Statham if the government would be willing to erect a stone over her grave. Unlike the case of Tāwhiao, Statham was clear in her view when delivering the proposal to Hislop:

Sophia was the means of saving the lives of several Europeans at Wairoa at the time of the Tarawera Eruption, and therefore can most certainly be called a historical personage. ${ }^{62}$

By 'saving the lives of several Europeans' and Sophia perfectly fitted the mould of imperial ideas of being both Māori and worthy of recognition. While this historical framing appears to further exemplify the tendentious, imperial nature of Statham's selective memory, there is also something to be said about how Sophia as a career woman may have fitted into Statham's own pursuit of progressive female citizenship. ${ }^{63}$ This process of selection by Statham suggested that Māori would have a presence in New Zealand historical memory, but only a conditional one.

For most of the time that Statham had been travelling through the Waikato, Bay of Plenty and Northern Taranaki sites, Cowan largely remained in Lyttelton, where he continued reporting for the Lyttelton Times and Christchurch Star. ${ }^{64}$ Like the rest of New Zealand, in 1914 Cowan followed the proclamations of war and considered how the Dominion might contribute to the imperial conflict. When the New Zealand contingent stormed the beaches of Apia in August, Cowan was inspired. Drawing upon the materials he had gathered on his trip to Samoa in 1899, Cowan compiled an illustrated booklet entitled 'Samoa and its Story' which included the New Zealanders' landing as part Samoa's historical timeline. ${ }^{65}$ When it was released it was reported in newspapers as 'very opportune' in its timing and as a 'souvenir', 'particularly suitable for all New Zealanders to mail to friends overseas. ${ }^{66}$ Because of the anonymity of journalists at this time, it is difficult to ascertain whether Cowan had been in a reportorial position when the commemorative monuments in Tauranga and Waikato were being unveiled just before the outbreak of war. A photograph of four of the Ngāti Maniapoto combatants on the battlefield at the 1914 commemoration is commonly attributed to Cowan, but in Cowan's own work is cited as

\footnotetext{
${ }^{60}$ Edith Statham to James Hislop, 11 October 1917, 'War Graves - Maori Guide (Sophia) Rotorua’, ACGO 8333, IA1, Box 1294, Record 7/4/75, ANZ.

${ }^{61}$ Jenifer Curnow, 'Hinerangi, Sophia', DNZB, Te Ara, 1993, updated 2015; https://teara.govt.nz/en/biographies/2h37/hinerangi-sophia; accessed 23 July 2021.

${ }^{62}$ Edith Statham to James Hislop, 11 October 1917, ACGO 8333, IA1, 1294, 7/4/75, ANZ.

63 Jenifer Curnow, 'Hinerangi, Sophia', DNZB, Te Ara.

${ }^{64}$ Colquhoun, 'Cowan, James', DNZB, Te Ara.

65 James Cowan, Samoa and its Story, (Christchurch: Whitcombe and Tombs, 1914), p. 58.

${ }^{66}$ Press, 24 October 1914, p. 1; 'New Books and Publications', Press, 31 October 1914, p. 7.
} 
being taken by G. Bourne ${ }^{67}$ It has been hypothesised by historians David Green and Vincent O’Malley, that Cowan was there as a representative for the Auckland Star. ${ }^{68}$ Though without confirmation of this, and considering Cowan's Christchurch locale, it is equally as possible that he had not been there.

Another report published in the notes and comments section of the Lyttelton Times, a month after the unveiling of the Ōrākau monument, and a couple of days after Te Ranga, also suggested that whoever had written it was profoundly impacted by the occasions:

The passage of the years quenches the old racial hatreds, though not the pure flame of patriotism. Even in New Zealand we have seen deadly animosities swept away in two generations. Only the other day Europeans and Maoris gathered at Tauranga to do the honour to the memory of the gallant Rawiri, the chief who inflicted the defeat at the Gate Pa upon a picked force of the British navy and army, and who fell in the trenches of Te Ranga a few weeks later. The brotherly celebrations of Pakeha and Maori at Orakau, too, will be fresh in the memory. These battles were but fifty years ago, yet the two races join in fraternal worship of each other's heroes. The memory of Bannockburn remains as a common heritage for the AngloSaxon-Celtic stock, an inspiration to heroic deeds and to desperate blows for freedom; and a white New Zealand mounted rifles regiment in the North has taken lesson from the brown rebels whom Cameron defeated but could not conquer, and as adopted the reply at Orakau "we will fight on for ever and ever" as its motto and has inscribed it in Maori upon its colours, an antipodean "scots wha hae." 69

The extravagant account of the recent events in the North Island, amongst the hum of daily commentaries, suggested a passion of someone intimately tied to the people and the place.

Nevertheless, Cowan appeared rather absent in publications and reports over the next two years, as the Dominion's soldiers landed and withdrew from Gallipoli and moved to the western front. It was not until November 1917, that he would reappear in print in a significant way. In early November Cowan, along with veteran Colonel Thomas Porter, met with the Minister of the Department of Tourist and Health Resorts, William Macdonald, to propose that Cowan be funded by the government to record 'native historical and other information as a national work. ${ }^{\text {,70 }}$ Porter's engagement from this early stage was significant. A veteran of the wars with Māori himself, serving in the pursuit of Te Kooti, Porter had also been in command of the seventh New Zealand contingent during the South African War, and upon his return had served as military commander of the Canterbury district, amongst other, more

\footnotetext{
67 James Cowan, The New Zealand Wars Vol. I, p. 405.

68 Vincent O’Malley, The Great War for New Zealand:Waikato 1800-2000, p. 23.

${ }^{69}$ Lyttelton Times, 24 June 1914, p. 8.

70 James Cowan to William D.S. Macdonald, 16 November 1917, ACGO 8333, IA1, 1280, 4/2/13, ANZ.
} 
political postings. ${ }^{71}$ His involvement with Cowan's late 1917 proposition however, came at the same time that he had been made inspector of recruiting services, assisting with the detection of men evading conscription. ${ }^{72}$

Cowan's initial proposal to Macdonald appeared as a continuation of his earlier tourism work. Not only did he pitch the potential 'New Zealand War History' and 'Maori Historical and legendary material' to the Minister of Tourism and Health Resorts, but he also explicitly suggested that the research could also be used for 'articles and booklets for advertising purposes, for circulation by the Tourist Department, similar to the literary matter which I prepared during my six years engagement with the Tourist Department (1903-1909). A great deal of useful material for publicity purposes could be written this way, for use by the Department when the opportunity offers. ${ }^{73}$ The correspondence with Macdonald suggested that Cowan was still seeing the work within a Maoriland lens, except with the collaboration with Porter suggesting a move from the slightly more light-handed appropriations of the turn of the century to something politically defined. It also marked the moment that Cowan began to explicitly centralise his authority and expertise, on the basis of having grown up with Māori on the border between te ao Māori and settler endeavours, in his work. In rounding out his suitability for the task Cowan cited his 'intimate knowledge of the Maoris [sic] and the Maori language, from boyhood, would, I submit, be of service in such work; and I think my literary record would guarantee the attractive presentation of the data obtained. ${ }^{, 74}$

It appears that at this early part of the lobbying to have a history of the 'Maori wars' along with 'valuable information regarding the Maori' gathered and written, there was confusion over who should be tasked with the job. ${ }^{75}$ The initial call for a history had come from Napier Mayor and former correspondent of Robley, Henry Hill. In October 1917 Hill wrote to Prime Minister Massey directly suggesting that it be Porter who write the history, suggesting his 'reminiscences dealing with Te Kooti, Hauhauism and the King movement' would be invaluable. ${ }^{76}$ But it became apparent that Porter, most probably preoccupied with his duties in the present war, would not be able to produce a history of the 'Maori Wars.' But as evidenced by the correspondence with Macdonald, Porter and Cowan were already in communication about the potential history and Cowan's eagerness for the position. During this time a series of other figures joined the campaign to support Cowan's recruitment. On 1 December 1917, J. Allen Thomson, Director of the Dominion Museum, wrote to Under Secretary of the Department of Internal Affairs, James Hislop, suggesting that in the absence of Porter, Cowan could

\footnotetext{
71 J. A. B. Crawford. 'Porter, Thomas William', DNZB Te Ara, 1993;

https://teara.govt.nz/en/biographies/2p26/porter-thomas-william; accessed 4 July 2021.

72 Ibid.

73 James Cowan to William D.S. Macdonald, 16 November 1917, ACGO 8333, IA1, 1280, 4/2/13, ANZ.

${ }^{74}$ Ibid.

75 James Hislop, G.W. Russell, 6 December 1917, ACGO 8333, IA1, 1280, 4/2/13, ANZ.

${ }^{76}$ Henry Hill to William F. Massey, 8 October 1917, ACGO 8333, IA1, Box 1280, 4/2/13, ANZ.
} 
write a 'popular history' of the wars, suitable for educational purposes. ${ }^{77}$ Hislop, concurring with Thomson's views, passed on the message of support for Cowan, as well as a part of Hill's original letter, to the Minister of the Department of Internal Affairs George W. Russell. ${ }^{78}$ In his own direct correspondence with Russell on 4 December, Porter supported Cowan's appointment over his own:

I have no desire, nor do I consider myself capable of such a responsibility. I have much material that I would gladly supply and assist such a qualified linguist as Mr. Cowan. As previously recommended it is an important work the expense of which could be borne jointly by the Internal Affairs, Tourist and Native Departments. ${ }^{79}$

Perhaps the most resounding messages of support came from long-standing editor of the Auckland Star Thomson Leys, who had overseen Cowan's journalism work in his early career. In his initial correspondence with Russell, received on 7 December, Leys argued:

The government employed Mr. Colenso and Mr. John White for many years to write early histories of the Maoris; and a history of New Zealand's share in the present war - a much less important matter from a national point of view than the struggles of which our early settlers were engaged is now contemplated. Do you not think that the government should avail themselves of the service of Mr. Cowan - who is at present free to undertake the work? ${ }^{80}$

Leys' argument inferred that the present war, regardless of its significant and ongoing toll on New Zealand, was not as important to nationhood as the wars that had been fought on New Zealand soil. While there were two sides to the wars in New Zealand, it seems that Leys identified a history of those wars as an opportunity embolden a sense of the locale, by emphasising the 'struggle' of pioneering ancestors to strengthen a national attachment to place. ${ }^{81}$

Cowan directly addressed Russell in a letter received around the same time of Leys', advocating for the 'national history of the wars of New Zealand' and his suitability for the role. In his opening passage, Cowan's sentiment both echoed the principles of the Victoria League, whilst leaning more into a nationalist rhetoric as much as imperial allegiance:

The wars between the Maoris and the British and Colonial forces and the troubled and uncertain conditions of settlement attendant upon those wars not only formed the most adventurous and romantic epoch in New Zealand's history but were the most vital period of its national existence. Those events were at the very foundations of the Dominion's life; they touched our people more directly than even the great war to-day, for the danger was within our own gates.

\footnotetext{
77 J.Allen Thompson to James Hislop, 1 December 1917, ACGO 8333, IA1, 1280, 4/2/13, ANZ.

78 James Hislop to George W. Russell, 6 December 1917 , ACGO 8333, IA1, 1280, 4/2/13, ANZ.

${ }^{79}$ Colonel Thomas W. Porter to George W. Russell, 4 December 1917, ACGO 8333, IA1, 1280, 4/2/13, ANZ.

80 Thompson W. Leys to George W. Russell, 27 November 1917, ACGO 8333, IA1, 1280, 4/2/13, ANZ.

${ }^{81}$ Veracini, 'Historylessness', p. 274.
} 
It was only the successful settlement of these wars that made it possible for the Dominion to take its present place in the ranks of the fighting countries in the Empire's defence. ${ }^{82}$

Cowan went on to outline his methodology: that the war history would be borne out of both Māori and European participant accounts, along with the prospective chronology of the events, from 'Hone Heke's war in the north' in 1845-46 to 'Te Kooti's campaigns' in $1868-1871 .{ }^{83}$ He then finished his proposal with the strong topical assertion that 'the proper recording of our war history is a national responsibility. ${ }^{, 84}$

This martial declaration, in part pertaining to the contemporary war was also in reference to sense of urgency that ran through all of the letters in support of the work to the government at this time: that the work must be done before the passing of potential informants. In Cowan's earlier correspondence to Macdonald, his position as the middleman between the government, wider Pākehā society and the people of the past, which in Cowan's inferences was the category where Māori lay, was made even more crucial by that fact that informants were dying:

[I] beg to express the opinion that that it would be wise not to delay the task of interviewing the sources of information, European and Maori, until after the war or some indefinite period, for the authorities on these events of the past are fast disappearing through death. ${ }^{85}$

The statement echoed Hill's earlier sentiments that 'a few more years will naturally see the passing of the earlier actors in the drama of settlement of the North Island. ${ }^{, 86}$ Leys too, in his insistent manner asked 'now, is the Government willing that this final opportunity of obtaining information from firsthand sources be neglected? I hope not. ${ }^{87}$ The urgency in this sentiment was reminiscent of Pākehā ethnologies that both Cowan and Robley were, to varying degrees, producing around the turn of the century. Much of the value of Māori antiquities and sources of information lay in the idea that traditional or authentic Māori culture was on the verge of disappearing forever. ${ }^{88}$ This, in turn, placed value on the work of experts and middlemen like Cowan who could salvage remnants of history and tradition. But in this set of correspondence about New Zealand history and the wars between British and Colonial forces and Māori, it seemed that settler informants were made to seem just as on the verge of vanishing as those Māori informants. The task it seemed, was not just a salvaging of a certain 'type' of Māori, but

\footnotetext{
82 James Cowan to George W. Russell, 28 November 1917, p. 1, ACGO 8333, IA1, 1280, 4/2/13, ANZ.

83 Ibid, pp. 3-4.

84 Ibid, p. 5.

85 James Cowan to William D.S. Macdonald, 16 November 1917, ACGO 8333, IA1, 1280, 4/2/13, ANZ.

${ }^{86}$ Henry Hill to William F. Massey, 8 October 1917, ACGO 8333, IA1, 1280, 4/2/13, ANZ.

87 Thompson W. Leys to George W. Russell, 27 November 1917, ACGO 8333, IA1, 1280, 4/2/13, ANZ.

${ }^{88}$ Conal McCarthy, "Empirical Anthropologists Advocating Cultural Adjustments”: The Anthropological Governance of Āpirana Ngata and the Native Affairs Department', History and Anthropology, Vol. 25, No. 2, 2014, p. 287.
} 
also the 'type' of European that could meet the warrior race as equal adversaries on the battlefield, who were also key in the ‘struggle' of making a 'home' in the landscapes of New Zealand.

Russell and Hislop, both apparently supportive of the prospect of hiring Cowan on a government salary to conduct the research, began the work to bring the issue before the Cabinet and gather the resources of remuneration for Cowan's prospective position. ${ }^{89}$ However, given that the country was three years into a costly war, the government did not have a wealth of funds to support a new officer's salary. After deliberating on whether Cowan's salary might come out of the estimates for the Dominion Museum, it was ultimately decided in December 1917 that the government could not fund Cowan to do the history work at that time. ${ }^{90}$ Porter responded to this verdict in January 1918 by gathering a series of further referees for Cowan, including Leys, collector and gallery owner, Henry Partridge, editor of the Christchurch Star D. McLennan and a review from the Melbourne Argus that suggested Cowan's work on Māori was the best since Frederick Maning's Old New Zealand. ${ }^{91}$ In the meantime Russell then broke the news to Leys in late January 1918, whose response was of characteristic form:

I was very sorry to learn from your letter of the $21^{\text {st }}$ of January that the Cabinet has decided against the appointment of Mr. Cowan, to prepare an official history of the Maori Wars... Very heavy expenditure is being incurred to in connection to the historical records of New Zealand's share in the present war and yet a matter which, to my mind, is of equal urgency and importance is being neglected... The New Zealander of the future should be proud of the courage, enterprise and self-reliance of the pioneer settlers as the Americans to-day are of the heroes of the Revolution. But, unfortunately, there is nothing to stimulate their patriotism or to impress upon the minds of the generation of young New Zealanders the fact that colonisation of these islands was characterised by distinctive features that have exercised a material influence in developing the country. ${ }^{92}$

On 16 February, Prime Minister Massey became involved, responding to Porter's report and assuring him that he would bring the matter before Russell for reconsideration. ${ }^{93}$ As a result, the decision was reversed and by 28 February 1918, Russell and Hislop reported to the various interested parties that

\footnotetext{
${ }^{89}$ George W. Russell to Thompson W. Leys, 4 December 1917; G.W. Russell to James Hislop, 21 December 1917, ACGO 8333, IA1, 1280, 4/2/13, ANZ.

${ }^{90}$ F. Brooker to James Hislop, 17 December 1917, ACGO 8333, IA1, 1280, 4/2/13, ANZ.

${ }^{91}$ Colonel Thomas W. Porter, ‘Memorandum', 21 January 1918, ACGO 8333, IA1, 1280, 4/2/13, ANZ.

92 George W. Russell, to Thompson W. Leys, 28 January 1918; Thompson W. Leys to George W. Russell, 1 February 1918, ACGO 8333, IA1, 1280, 4/2/13, ANZ.

${ }^{93}$ William F. Massey to Colonel Thomas W. Porter, 16 February 1918, ACGO 8333, IA1, 1280, 4/2/13, ANZ.
} 
Cowan had been officially engaged in the work. ${ }^{94}$ By 9 March, Cowan was set up with a room in the 'old Custodian's residence' on Featherston Street in Wellington to conduct the historical work. ${ }^{95}$

The contract that Cowan received on his first day stipulated administrative matters, such as his remuneration of $£ 25$ per month, or $£ 300$ a year for a period of two years, but also set forth how Cowan's history was being framed within a governmental vision of the future. ${ }^{96}$ In the agreement, it was stated that the history that would be compiled by Cowan would become 'sole property of the government of the Dominion of New Zealand', giving the government 'full title to the copyright' and making Cowan's work a piece of public property. ${ }^{97}$ It also stipulated that the collection of 'data and publications in relation to the early history of the Dominion', an aspect of the project that had always featured as part of Cowan's proposals, would be conducted under the provision of the Science and Art Act 1913. The Act was the foundation of a proposal to have the Dominion Museum, Art Gallery and Library all in one location, but it also had stipulated the intention to fill those repositories with new acquisitions 'of articles and documents of scientific, artistic or historical value. ${ }^{98}$ While the Act itself did not explicate the work as a project of collecting nation-defining articles, it laid down the soil for the accumulation of documents that would earn such national standing. The Treaty of Waitangi, for example, having been 'rediscovered' by Robley's confidant Dr Thomas Hocken in 1908 in water-damaged and rat-eaten condition, was, in 1913, sent by the Internal Affairs Department to the Dominion Museum to undergo repairs for preservation. ${ }^{99}$ As Cowan's contract demonstrates, this kind of gathering of materials was for a collection of the nation. Cowan it seems was acutely aware of his responsibility, when on his first request to Hislop to travel out of Wellington he reaffirmed knowledge of his duty to gather material for the 'National Historical Collection Established by the Board of Science and Art.' ${ }^{100}$ Having previously been a 'foot soldier' in the world of New Zealand newspaper journalism, Cowan was now a fieldworker collecting material for a National Historical Collection.

In conducting the general collecting side of his work, Cowan's work began to cross over with Statham's efforts. In a letter to Cowan in July 1918, Under-Secretary James Hislop requested that Cowan start to obtain photographs of significant churches Cowan had reported on in his fieldwork so far, as well as 'other matters of interest relative to historic monuments in New Zealand.' ${ }^{101}$ The purpose behind this suggestion was to publish a booklet on those historic sites. The gravesites attached to many of these churches were tended to by Statham in the early years of her government contract, some of

\footnotetext{
${ }^{94}$ George W. Russell to Thompson W. Leys, 28 February 1918, ACGO 8333, IA1, 1280, 4/2/13, ANZ.

95 James Cowan to George W. Russell, 7 March 1918, ACGO 8333, IA1, 1280, 4/2/13, ANZ.

${ }^{96}$ ‘Contract of James Cowan of Wellington', 9 March 1918, ACGO 8333, IA1, 1280, 4/2/13, ANZ.

${ }^{97}$ Ibid.

98 Science and Art Act, 1913, 4. GEO. V. No. 22;

http://www.nzlii.org/nz/legis/hist_act/saaa19134gv1913n22196/; accessed 26 January 2021.

${ }^{99}$ State Services Commission, The Journey of the Treaty, (Wellington: 2005), p. 11.

100 James Cowan to James Hislop, 29 April 1918, ACGO 8333, IA1, 1280, 4/2/13, ANZ.

101 James Hislop to James Cowan, 20 July 1918, ‘Inward Correspondence Re Cowan’s Literary Work’, MS-

Papers-0039-03, ATL.
} 
which, such as St Stephens in 1927 and St Paul's in 1929, were later reported by Statham to be transferred from the Church of England to local council 'to be preserved as a historical spot.' ${ }^{102}$ It is unclear whether Statham was entirely aware of, or concerned about the Science and Art Act established the same year her government contract had started. However, she started to demonstrate an awareness of the Act by sending significant material items that she came across in her memorial and grave renovation work to the Dominion Museum. In March 1917, Statham reported to Hislop about the condition of the cemetery at Rangiriri, pointing out 'a most peculiar wooden cross', that along with an inscription she explained had 'some very odd carvings and appears to have had some pieces of tin inlaid. It is in a pretty good state of preservation, but I am afraid it will not last much longer in the open.' ${ }^{103}$ Statham then asked: 'Do you not think it would be a good thing to present it to the Old Colonists Museum, it is quite a curiosity, and if indoors would last a long while yet?' ${ }^{104}$ Regardless of Statham's knowledge of the Act, the example appears as testament to the collaborative effort to preserve by the history-makers, despite the different approaches to public memory that brought them to this moment.

By 1919 it was clear that Cowan and Statham were crossing paths in their work, as evidenced by their respective correspondence with their contemporary in London, Horatio Gordon Robley. Robley it appeared, had caught wind of Cowan's wars history and in March 1919 had sent a letter to his soonto-be-biographer Horace Fildes, reporting not only Cowan's work but Statham’s too:

It is James Cowan [who] has the order to go ahead with the Wars History '45 till [the] last scrap in NZ. I have written him some notes, on my time - his style will be different from Percy Smith. I also [heard from] Mrs. [sic] Statham of the Internal Affairs Office [who] wrote me [that] the cemeteries and graves are all seen to now. ${ }^{105}$

In a response from June of the same year from Statham to Robley, she affirmed that she and Cowan were also in correspondence:

I was glad to hear from you, and am sending on your letter to James Cowan, I regret much that I have not yet had the pleasure of meeting him, have just missed him in my travels, I hope to do so when I return to Wellington in a few months [sic] time. ${ }^{106}$

The triangular communication between the three during this early 1919 period indicated a sense of collaboration in preserving certain events and peoples of the colonial past. But as the next section

\footnotetext{
102 'Devonport - Old C of E Cemetery', 'St Stephens Cemetery - Old Soldiers Graves', ACGO 8398, IA 76, 1, 1 , ANZ.

${ }^{103}$ Edith Statham to James Hislop, 31 March 1917, ACGO 8333, IA1, 1289, 7/4/20, ANZ.

104 Ibid.

${ }^{105}$ Horatio Gordon Robley to Horace Fildes, 10 March 1919, FILD0035a, JCBR.

${ }^{106}$ Edith Statham to 'General Robley’, 18 June 1919, FILD0035a, JCBR.
} 
demonstrates the nature of the relationships, particularly between Cowan and each of the other two, served rather different purposes.

For Statham, who continued to work away on the memorials and gravesites, Cowan's work promised to be a written companion to the significant sites she was working with. In August 1920, Statham had returned to Ōrākau to assist with drafting an inscription on the battle site memorial. Later submissions for an inscription were much less detailed, containing mostly short biographical details and considerations to add the famous 'Ake! Ake! Ake!' line. ${ }^{107}$ But by this point the prospect of a separate memorial just for the Māori who were buried at the Ōrākau site was being entertained by the Kihikihi locals, and Statham was on board. ${ }^{108}$ When Statham arrived back at Ōākau, she again deliberated what information was necessary to include in the memorial inscription. As part of these deliberations, she remarked to Hislop that both 'men and women' had laid down their lives for the pa but that 'Mr. Cowan in his history will be sure to mention the fact. ${ }^{109}$ There is a sense here that Statham was cognizant of how her and Cowan's work were relating and how their work might collaboratively shape the experience of those reading the history and visiting the historical site.

More significantly for Robley, Cowan's official history of the period and events in which he made his 'inroad' to New Zealand, fighting in the British Army against Tauranga Māori in 1864-66, appeared the perfect opportunity to finally make his name and his work known in the 'land of the Maori.' A month after the erection of the monument at Te Ranga in June 1914, Robley had finally achieved part of his wish in his earlier attempts to repatriate his collection of mokomokai. That was, to have his collection be displayed as part of a national New Zealand collection of art. The watercolours and sketches made by Robley and purchased by Donne in 1905 were put on display at the Dominion Museum. ${ }^{110}$ The timing of the exhibition corresponded with the flurry of 50th anniversaries of battles of the 1860s. Aside from this, Robley had continued to create visual narratives of New Zealand and especially New Zealand at the time of the 1860s wars. He did this through his production of tiki sketches for New Zealand soldiers to send back to their families from the metropole and in the moments of engagement at New Zealand House. The most prominent example was his involvement in the decoration and set up of a reception to welcome Prime Minister Massey to London in 1917. In an article about Massey's time in London in the Christchurch Press, it was reported that the function was held at the Hotel Cecil and that Robley had been commissioned to design and decorate a speech platform, which he chose to depict as the 'front of a Maori runanga.' ${ }^{111}$ The meeting with Robley had an impact on Massey. In 1919, the Prime Minister promised Robley that he would

\footnotetext{
107 J. Allen Thomson to James Hislop, 20 May 1920, ACGO 8333, IA1, 1292, 7/4/38, ANZ.

${ }^{108}$ Edith Statham to James Hislop, 5 August 1920, ACGO 8333, IA1, 1292, 7/4/38, ANZ.

109 Edith Statham to James Hislop, 5 August 1920, ACGO 8333, IA1, 1292, 7/4/38, ANZ.

110 'Maori War Pictures; Historical Collection', NZH, 20 July 1914, p. 8.

111 'Ministers at Home: Arrival in England', Press, 4 December 1916, p. 10.
} 
argue for a series of mokomokai sketches which Robley had retained to be purchased by the New Zealand government. ${ }^{112}$

Massey's promise paled in comparison to the opportunity that was now being presented by Cowan's historical work: if Robley could contribute to this major account of the wars he might find a place in a narrative that would be of wide influence. In a letter from Robley to collector and bibliographer Horace Fildes in March 1919, Robley applauded Cowan's selection as the person to write the 'Wars History '45 till [the] last scrap in NZ' and that he had already written Cowan some notes about his own experience in New Zealand during that time. ${ }^{113}$ As highlighted in Chapter One, at some point during that year, Fildes travelled to London where he obtained Robley's full collection of autobiographical notes about, not just his time in New Zealand, but all the activity thereafter that had been shaped by the experience. ${ }^{114}$ In the account, Robley painted his journey to and from 'the land of the Maori' as his own odyssey, investing characters and experiences with mysticism. The most high-flown moment was when he described seeing nymphs at the water's edge on his return via the Azores. ${ }^{115}$

The autobiographical account provided to Fildes by Robley did not explicitly state that it was for the purpose of Cowan's history, but the series of correspondence with Fildes and Cowan thereafter suggested that was exactly what it was for. Throughout the next two years it appeared from his correspondence with Fildes that Robley had become fixated on having his account of his time in New Zealand included in Cowan's writing. In a series of letters during October and November 1920, Robley instructed Fildes to send on the copies of his sketches of Gate Pā and other events for Cowan to use as a 'photo guide'. ${ }^{116}$ In another letter, referencing Lindauer's portrait of Taraia, he asked Fildes to pass on the part of Robley's account about his friendship with Taraia to Cowan. ${ }^{117}$ On 30 November, Robley contacted Cowan directly again recounting some of his experiences, reminding him that Fildes had the full accounts of certain points of potential interest to Cowan, such as the time that he was selected as a marksman for the Māori water supply before the battle of Gate Pā. ${ }^{118}$ Another element of Robley's appreciation of his importance to Cowan's narrative was his contemporary London context that put him in proximity, not just with the events of New Zealand's colonial past, but also the recent war that had set Cowan's official history in motion. In a note to

\footnotetext{
112 Horatio Gordon Robley to Elsdon Best, 4 May 1919, MS-Papers-0072-05A, ATL.

${ }^{113}$ Horatio Gordon Robley to Horace Fildes, 10 March 1919, FILD0035a, JCBR.

${ }^{114}$ Walker, ‘Robley: Te Ropere 1840-1930’, p. 10.

${ }^{115}$ Fildes, 'Major General H. Gordon Robley: Soldier and Artist', 1921, Fildes MSS 1507, JCBR, p. 107.

${ }^{116}$ Horatio Gordon Robley to Horace Fildes, 10 November 1920, 'Robley, H. G. (Major-General)', 1920, Box 10, FILD00035b, JCBR.

${ }^{117}$ Horatio Gordon Robley to Horace Fildes, ‘Hallowe’en’ 1920, FILD00035b, JCBR.

${ }^{118}$ Horatio Gordon Robley to James Cowan, 30 November 1920, 'Correspondence’, MS-Papers-11310-105, ATL.
} 
Fildes in 1921, Robley emphasised his encounters with the soldiers who had been on leave in London and being able to witness their 'exemplary' behaviour:

at the end of the Great War, I must record the opinion in London of NZ troops those who wore the joy hats, that when they returned to the Dominion and were no more seen, the remembrance of them, was of an act of gentlemen cavaliers of the very best, that is what they took away from London and its visitors. We missed the wearers of the Joy hat, I was proud to see the pictures of their deeds and places [drawn] by splendid artists amongst them, who recorded war scenes so truthfully. ${ }^{119}$

In a letter to Donne from about the same time, Robley underlined his unique position as a witness to New Zealand's coming of age; 'I had seen NZ in '66 begin on her own without imperial troops - Now New Zealand was in force aiding Empire; and with such good men as all knew., ${ }^{120}$

There was little evidence to suggest how Cowan was responding to this correspondence from Robley. By February 1920 Cowan reported his progress to Hislop:

I have visited the greater number of the places associated with the wars, making topographical notes and sketches. Wherever possible I have had the assistance on the spot of European and Maori veterans who served in the engagements. Battlefields and sites all over the islands have been examined, and material for a complete set of illustrations of these places is being obtained... The result is that a very large amount of valuable material has been accumulated and more is coming to hand from eyewitnesses and participants in the most important events in New Zealand history... I am anxious to gather as much oral testimony as possible before it is too late. In another four or five years the opportunity will be gone. ${ }^{121}$

Cowan had originally intended to structure the projected publication on the New Zealand Wars as four volumes: the first covering from 'Heke’s War in the North' to the fighting at Wanganui; the second covering 'the Waikato Campaign;' the third covering 'the Hauhau wars and fighting in Taranaki;' and the fourth discussing 'The Hauhau wars on the East Coast and Te Kooti's trail. ${ }^{122}$ After three years and four requests for extension on the two year project Cowan had condensed the material into two volumes, the first being published in 1922 and the second in $1923 .{ }^{123}$

Cowan's publication, incorporating the written and oral accounts of both Pākehā and Māori veterans in a lively, exciting historical account, was like nothing that had come before. As Leys had

\footnotetext{
${ }^{119}$ Horatio Gordon Robley to Horace Fildes, c. 1921, FILD00035c, JCBR.

${ }^{120}$ Horatio Gordon Robley, 'A History of the Maori Tiki by Te Ropere’, MS-Papers-1387-14, ATL.

121 James Cowan to James Hislop, 18 February 1920, ACGO 8333, IA1, 1280, 4/2/13, ANZ.

122 James Cowan to James Hislop, 8 March 1918, ACGO 8333, Series IA1, 1280, 4/2/13, ANZ.

123 James Hislop to the Minister of Internal Affairs, 8 March 1920, 11 March 1921, 30 June 1921, 7 September 1921, ACGO 8333, Series IA1, 1280, 4/2/13, ANZ.
} 
pointed out about the work at the beginning of Cowan's contract, 'there is plenty of romance in the early history of New Zealand without embellishing fact with fancy; and we are now far enough away from the events to view them impartially and in their true perspective. ${ }^{124}$ When Cowan published The New Zealand Wars four years later he claimed both of Leys’ assertions: Describing his approach as having 'the impartial spirit of the historian', Cowan explored the 'adventure-teeming' lives of the pioneers and veterans of his fieldwork. ${ }^{125}$ Cowan pushed the nationalist sentiment in the work in a variety of ways. Most prominent was his distinction between the colonial forces that were more astute in their opposition to Māori than the blundering imperial forces. ${ }^{126}$ Cowan's emphasis on both 'the military genius of Maori' and 'the soldiering capacity of the settler Volunteers' was imbued with ideas of the martial colonial masculinity that permeated the mythologies of New Zealand's distinction amongst the imperial forces in the Great War. ${ }^{127}$ His description of Ngāpuhi combatants as 'the pick of Maori manhood' which he goes on to detail as 'tall fellows, with the shoulders and chests of athletes and the straight backs of soldiers', echoed the rhetoric of New Zealand's exemplary modern and superior masculinity on the battlefields of Europe, compared the 'degenerative' forms of masculinity in the old world. ${ }^{128}$ Cowan would often drive home the hereditary predisposition for this uniform New Zealand modern masculinity, by indicating the shared martial characteristics between Māori and those of Scottish and Irish ancestry. ${ }^{129}$

Such assessments were not applied to all Māori combatants however, just those whose stories would fit into an archetypal heroic narrative. In line with the portrayals of Ōrākau, if Māori combatants were willing to lay down their lives for their cause Cowan would portray them as noble and heroic, worthy of European praise, such as in the examples of Hone Heke and Te Ruki Kawiti at Ruapekapeka or when Ngāti Haua, Waikato and Maniapoto refused to bow down at Mahoetahi. ${ }^{130}$ The account of Ōrākau was unsurprisingly filled with colourful, romantic imagery of Rewi and Ngāti Maniapoto, choosing 'death before dishonour.' ${ }^{131}$ When it came to incorporating those Māori of the Hauhau forces, Cowan drew the line of acceptable behaviour between those who could control their innate martial savagery and those, like the 'fanatic' Hauhau, who in Cowan's mind had lost all semblance of appropriate, civilised behaviour. ${ }^{132}$ The publication marked the endurance of the Pākehā dictation of an ancient Māori past, sending the message that those 'traditional' Māori virtues would be

\footnotetext{
124 Thompson W. Leys to George W. Russell, 7 March 1918, ACGO 8333, IA1, 1280, 4/2/13, ANZ.

${ }^{125}$ Cowan, The New Zealand Wars Vol. 1, p. xiii.

126 Ibid, p. 161, 183.

${ }^{127}$ Ibid, p. 161; Loveridge, "'Soldiers and Shirkers”, p. 66.

${ }^{128}$ Ibid, p. 55, Loveridge, “'Soldiers and Shirkers”, p. 63.

${ }^{129}$ Cowan, The New Zealand Wars Vol. II, pp. 8, 17,

${ }^{130}$ Cowan, The New Zealand Wars Vol. 1, pp. 87, 107.

${ }^{131}$ Ibid, p. 208.

132 Ibid, pp. 175, 241.
} 
acceptable in New Zealand's future, as long as they did not challenge the notion of New Zealand as an exemplary Dominion within imperial cultural values.

Despite Robley's frequent correspondence, aside from including Robley's sketch of the Gate Pa trenches and the surrender of Ngai-te-Rangi at Te Papa, Cowan did not mention Robley's account at all. ${ }^{133}$ In a letter to Fildes in January 1923 close associate of Cowan, Gilbert Mair, explained that 'his narrative of Gate Pa was all too brief', but as Mair understood Cowan had 'had orders to curtail it.' 134 Not all had been lost however. In September 1920, a year after he had obtained Robley's autobiographical notes, Fildes published an abridged version of the narrative in the Evening Post entitled 'The Maori Wars: Major General Robley, Soldier and Artist.' 135 There was evidence to suggest that all the correspondence from Robley did have an effect on how he was received by those in New Zealand. In February 1924, it was reported in the Christchurch Press that Robley's collection of 35 mokomokai had recently been purchased by the American Museum. ${ }^{136}$ The next day Fildes contacted the paper clarifying that the collection had actually been sold in 1908, not recently. ${ }^{137}$ In response to what appeared to be renewed interest in Robley and his former collection, Fildes went on to say: 'it was General Robley's earnest hope that the New Zealand government would purchase the collection, and more than one opportunity was given to do so. ${ }^{138}$ Regardless of popular perception, Robley always had the support of his correspondents in New Zealand. In 1923 for example, Robley recounted a letter from Gilbert Mair that read: 'You are the greatest acknowledged authority - [Māori] look upon you as the preserver of the most interesting custom existing. ${ }^{139}$ Robley was not a significant part of the written history of the events that brought him to New Zealand, but as the next chapter demonstrates, he would find alternative ways to leave a legacy as well as reflecting on the one he already had.

By the time Cowan published The New Zealand Wars in 1922-23, the nature of Statham's work had finally been impacted by the costs and needs of the recent war that had followed her old soldier grave work all along. By the time armistice was called in 1918, around 18,000 New Zealand men had died with 16,697 of those being buried where they had fallen. ${ }^{140}$ In response to this huge task of memorialising the recent war dead of the continental battlefields, Statham was transferred in 1921 to the new ‘War Graves Division’ of the Department of Internal Affairs, working under L.E. Scott. ${ }^{141}$ The work involved inspecting the suitability of the often publicly-funded memorials around the country for the local soldiers buried in distant places and caring for the graves of those soldiers who had died shortly

133 Cowan, The New Zealand Wars Vol. II, pp. 430, 438.

${ }^{134}$ Gilbert Mair to Horace Fildes, 8 January 1923, 'Mair, Gilbert, 18 Nov 1920 - 8 Jun 1923’, FILD00027, JCBR.

${ }^{135}$ Horace Fildes, 'Maori Wars: Major General Robley’, 4 September 1920, EP, p. 9.

136 'To-Day’s News’, Press, 26 February 1924, p. 8.

137 'Maori Heads', Press, 27 February 1924, p. 11.

138 Ibid.

139 Robley, ‘Army Service from 1858', c. 1919, FILD00056, JCBR, p. 74.

140 Phillips, To the Memory, p. 87.

${ }^{141}$ Ibid, p. 46. 
after their return to New Zealand. ${ }^{142}$ Hislop informed her that any further old grave work would have to be done in her own time, her role as the official 'inspector of old soldier graves' coming to an end. ${ }^{143}$ But for Statham, who had never been afraid to push the government on her entitlement and duty to contribute to national and imperial greatness, the change in position would not spell the end of her engagement with the graves and the memory of a colonial past.

${ }^{142}$ Edith Statham, 'Report on work for June 1921', 8 July 1921, Edith Statham to Mr. Scott, 29 July 1921, ACGO 8333, IA1, 1661, 32/1/26, 1, ANZ.

${ }^{143}$ Phillips, To the Memory,p. 46. 


\section{Chapter Four History, Modernity, and the Forgetting of Settlement 1923-1940}

By the first months of 1923, Edith Statham was well into her new role assisting the establishment and maintenance of New Zealand Expeditionary Force (NZEF) memorials, Horatio Robley had not made it into James Cowan's historical account but was receiving ample affirmation from those friends in the Dominion and Cowan had by April finally got the second volume of The New Zealand Wars to print. The reception of Cowan's New Zealand Wars was resoundingly positive. The reviewer for the New Zealand Herald applauded the first volume for its virtues, insisting: 'It is a real history. It contains no trace of prejudice. It is fearlessly truthful. One feels instinctively that here is a record in which no attempt has been made to exaggerate virtues or obscure unpleasant facts. It is just to the pakeha and to the Maori.' ${ }^{1}$ Another from the Evening Post entitled 'The New Zealand Wars: 'Brave white and braver brown' claimed that 'many books have been written about New Zealand History, but this is the best of them all.' ${ }^{2}$ Cowan's publication marked a significant moment in New Zealand's understanding of its own past. This chapter looks at the period after its publication from 1923 to the point in time when Cowan and Statham's work began to slow as the centennial year of 1940 approached, and ten years after their old collaborator Robley had died. Examining these final years of Cowan, Statham and Robley's careers and lives, this chapter addresses how their portrayals of the colonial past continued in their more varied work into the 1920s, a decade marked by more concerted memory making in the wake of Great War losses. It also looks at the nature of this new work and how the historymakers themselves sought to influence developments around new and positive public engagements with the history of New Zealand they had propagated. As their careers and lives came to an end, this chapter reflects on the relationship between their own colonial experiences set forth in the first chapter and the reality of what they were able to achieve in their respective lifetimes.

This chapter predominantly looks at the later work of younger two of the three history-makers, Cowan and Statham, though attention will be paid to the final years of Robley's life before his death in 1930. It is structured in two major parts: the first being an examination of their final years under government salary, with one more collaboration between the two at Rangiriri cemetery, Statham retired from the public service in 1928 while government funding of Cowan's writing ended in 1930. This first section begins with Cowan's work after The New Zealand Wars, then Statham's work at Rangiriri, finishing with an analysis of their different experiences under government contract. The two sections are separated by a discussion of the last years of Robley’s life. The discussion of Robley's final years

\footnotetext{
1 ‘Our Own History’, NZH, 2 December 1922, p. 1.

2 'New Zealand Wars: “Brave white and braver brown”, EP, 22 February 1922, p. 10.
} 
is an exploration of his reflections on his life and career, a period that begins with his affiliation with the Tauranga Savage Club and ends with a statement of humility about his long held claims of expertise and appropriations of Māori culture. The final part of the discussion looks at Cowan and Statham's work during the 1930s and the ways in which they attempted to sustain their focus on local history for future generations, through Statham's continued work at the Symonds Street cemetery and in Cowan's writing for children and involvement with those devising the school curriculum. Cowan, Statham and Robley's nascent, formative histories of place answered a settler-colonial need for territorial belonging in New Zealand. But when a more modern, professional style of history took hold, their histories and their intentions also became casualties of the settler colonial will to forget. In this chapter the contradictory nature of the history-makers' emphasis on colonial conflict within the necessary forgetfulness of New Zealand society is evident, and so is the overall implication of history in that process.

When Cowan finished the second volume of The New Zealand Wars in 1923, his government contract had technically come to an end. The government however, continued to supply him with a stipend for his continued production of articles and books to do with 'Maori history' right up until 1930. ${ }^{3}$ This was most likely to ensure that the material that was collected by Cowan during his fieldwork between 1918-1922 did get to see publication. At the time of the publication of The New Zealand Wars, this had become an issue of increasing concern at the Journal of the Polynesian Society, whose shrinking membership had created a back log of publishable research. ${ }^{4}$ While Cowan continued to receive government funding to write histories with the material he had collected, in 1923 the problems at the Polynesian Society provided the opening for the establishment of the Board of Māori Ethnological Research. The Board has been described by Conal McCarthy and Paul Tapsell as 'a remarkable story of indigenous agency' because of the way in which the Māori MPs involved, such as Apirana Ngata and Peter Buck, were able to steer Māori research towards a more Māori agenda. ${ }^{5}$ Despite Cowan's newly ratified reputation for being a just and fair representative of those (including Māori) giving accounts in his work, it was another prominent Pākehā ethnologist, Elsdon Best who was selected by Ngata to be involved in the new board for Māori research. ${ }^{6}$ In a later letter from Ngata to Buck, Ngata indicated a distaste for Cowan's 'populist' style of historical writing. ${ }^{7}$ Cowan's absence from the project

\footnotetext{
3 'Payments to James Cowan for Writing Official Maori History and Articles for Publications', 1934, ACGO 8333, IA1, 1280, 4/2/13, ANZ.

${ }^{4}$ Conal McCarthy and Paul Tapsell, 'Te Paori Whakapapa: The Origins, Operation and Tribal Networks of the Board of Maori Ethnological research 1923-1935’, Journal of the Polynesian Society, Vol. 128, No. 1, 2019 , p. 91.

${ }^{5}$ Ibid, p. 88.

${ }^{6}$ Conal McCarthy, “"Two branches of the brown Polynesians”: ethnographic fieldwork, colonial governmentality, and the "dance of agency", in Katie Pickles and Catharine Coleborne (eds.), New Zealand's Empire, (Manchester: Manchester University Press, 2016), p. 55.

${ }^{7}$ Blackley, Galleries of Maoriland, p. 237.
} 
seemed to serve as the first indication that his attempts to turn colonial conflict into a romantic localising narrative did not convince all his readers.

Nevertheless, over the next few years Cowan continued to push the ideas which he had set forth in the major publication. This was particularly true of his 1926 collaboration with Māori MP Maui Pomare on The Maoris in the Great War, in which Cowan appears to consolidate the relationship between the past antagonisms of the New Zealand Wars with the camaraderie on the battlefield that was being asserted during the First World War. In Greg Wood's 2010 study of Cowan's New Zealand Wars, he goes as far as to speculate that Cowan and Pomare's account of the Māori Contingent and Pioneer Battalion during the First World War was actually supposed to function as the third and final volume of The New Zealand Wars. ${ }^{8}$ Wood's interpretation suggests that Cowan was bringing those Māori fighting in the various battles from 1840 to 1914-18 into one cohesive developmental line, underlined with ideas of appropriate applications of old warrior behaviours. The Maoris in the Great War did seem to consolidate ideas around the symbolic nature of Māori on the battlefield to suit both national and imperial rhetoric in New Zealand. In the second chapter Cowan claimed that 'Those Pakeha New Zealanders who knew Maori well were delighted to think he was being given an opportunity to display his fighting qualities after many years of peace.' He went on to include a quote by 'an old colonist' from 1914:

These traditions, stories of great and glorious deeds of warfare, are the best guarantee we have that the Maori, even under the strange and disturbing conditions of modern warfare, will be a soldier of whom the Empire may be proud. All Maoris are intensely loyal to their race and intensely jealous of its reputation, and now that the Maori race is merged in the British Empire, that loyalty and that jealousy are transferred to Britain... if they are sent to the fighting line there will not be a man of them who will shrink from laying down his life for the Empire of which he is a part. I know that these men will welcome any chance to bring new glory to the Maori race, even at the sacrifice of their own lives. ${ }^{9}$

The publication appeared to set in stone Cowan's historical framework of his 1922-23 publications, whereby the New Zealand Wars functioned as a precursor to racial harmony in the Great War.

While Cowan enjoyed his newfound position as an acclaimed historian, Statham continued her work with NZEF memorials. The work with the new War Graves Division still required Statham to travel, but this time to focus on inspecting the newly erected Great War memorials and ensuring that all the deceased NZEF soldiers names (and their memory) were accounted for. ${ }^{10}$ In this work for the recent

\footnotetext{
${ }^{8}$ Greg Wood, 'Revisiting James Cowan: A Reassessment of the New Zealand Wars', MA Thesis, Auckland University, 2010, pp. 69-70.

${ }^{9}$ James Cowan, The Maoris in the Great War; A History of the Native Contingent and Pioneer Battalion Gallipoli 1915, France and Flanders, 1916-1918, (Auckland: Maori Regimental Committee, 1926), p. 11.

${ }^{10}$ L.E. Scott to Edith Statham, 7 June 1922, ACGO 8333, IA1, 1661, 32/1/26, 1, ANZ.
} 
war dead, Statham honed her creative eye for dignified, attractive and conspicuous monuments that would foster public remembrance. This had been a concern of Statham's from the 1910-14 period in which she was developing the Symonds Street memorial with the Victoria League in Auckland. ${ }^{11}$ In June 1921, while reporting to her new superior, L.E. Scott, Statham lamented the Parkinson and Co. masonry of a Returned Servicemen's Association's (RSA) memorial erected at Waikumete Cemetery in Auckland. The stonework, Statham complained 'did not appeal as a work of art.' ${ }^{12}$ In July 1921, after inspecting the new Parkinson and Co. monument at Waiuku she expressed similar concerns, criticising the bad workmanship, which she lamented again was 'not artistic at all. ${ }^{13}$ These memorials, often raised by the local community, were important sites of mourning for those who were distant from their deceased loved ones. But for Statham inspecting their standard, the work was also about encouraging a more collective ritual of remembrance of the soldier-citizen, and to do this, memorials had to be reverential, artistic, and inviting public monuments.

Despite this overwhelming responsibility to provide and ensure memorialisation of thousands of Great War soldiers buried in foreign lands, Statham would get another opportunity to revive her former position as government inspector of old soldier graves. In March 1924 James Hislop received a memorandum from the Minister of Internal Affairs who had visited the graveyard near the battle site of Rangiriri, reporting it to be in a very 'unkempt state. ${ }^{14}$ Upon receiving this notice, Hislop sent Statham's superior Scott to Rangiriri and make a report. ${ }^{15}$ Statham had her eye on the state of neglect of the Rangiriri grave site since $1912 .{ }^{16}$ Once the Minister's memorandum came through, Statham picked up where she had left off as best as she could with her limited spare time, this time in collaboration with Scott. By August 1925, the renovation work was underway refurbishing the memorials and grave markers that already stood. ${ }^{17}$ The project brought Statham back in collaboration with Cowan, when in the next month, referring to a telephone conversation between the two, Scott sent Cowan a letter asking him to amend and approve the lettering to be erected above the entrance way to the Rangiriri grave site. ${ }^{18}$ Cowan approved the inscription without amendment, the final copy presenting as much less challenging to the beliefs held by Statham a decade earlier [fig. 8]. ${ }^{19}$ There was no overt romanticism, just a note of the 'British casualties' and the 'Maori losses.' It also included the painful fact of the Rangiriri battle that 183 Māori had been taken prisoner, which seemed to contrast to the carefully worded 'heroic' inscriptions at St Johns in Te Awamutu and at Tauranga. The inscription

\footnotetext{
${ }^{11}$ Edith Statham to Hy Green, c. 4 August 1913, ACGO 8333, IA1, 1287, 7/4/2, ANZ.

12 Edith Statham to Mr. Scott, 20 June 1921, ACGO 8333, IA1, 1661, 32/1/26, 1, ANZ.

${ }^{13}$ Edith Statham to Mr. Scott, 29 July 1921, ACGO 8333, IA1, 1661, 32/1/26, 1, ANZ.

${ }^{14}$ Richard Bollard to James Hislop, 3 March 1924, ACGO 8333, IA1, 1289, 7/4/20, ANZ.

15 James Hislop to Richard Bollard, 13 March 1924, ACGO 8333, IA1, 1289, 7/4/20, ANZ.

${ }^{16}$ Edith Statham to Francis Bell, 30 May 1912, ACGO 8333, IA1, 1289, 7/4/20, ANZ.

17 James Hislop to Richard Bollard, 26 August 1925, ACGO 8333, IA1, 1289, 7/4/20, ANZ.

${ }^{18}$ L.E. Scott to James Cowan, 9 September 1925, ACGO 8333, IA1, 1289, 7/4/20, ANZ.

19 James Hislop to Richard Bollard, 21 September 1925, ACGO 8333, IA1, 1289, 7/4/20, ANZ.
} 
appeared as a 'fact' of history rather than a commemoration, seemingly influenced by the newer forms of war memorials in which the names of the dead were listed in a matter-of-fact fashion.

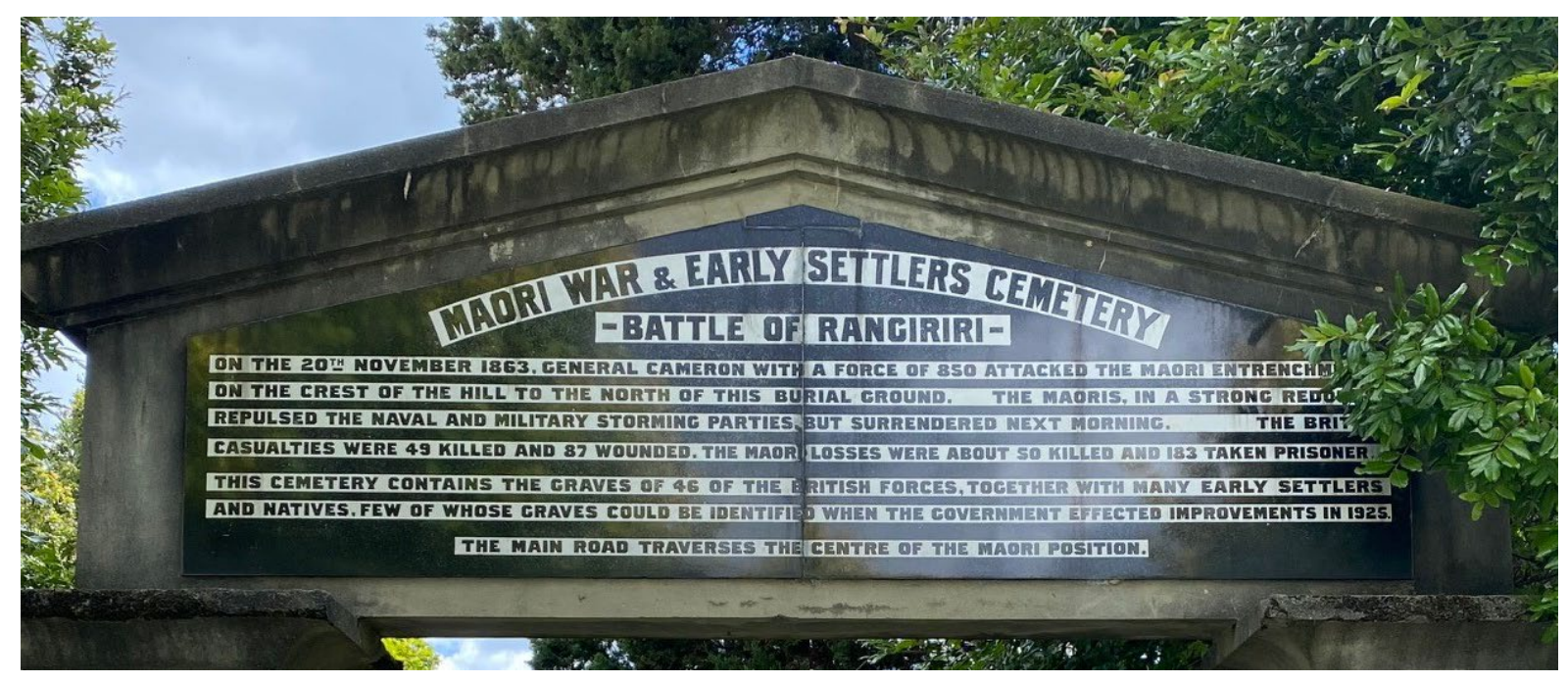

Fig. 8 - Rangiriri Memorial Gateway Inscription, photo by author, 4 January 2021.

In April 1927, the new Rangiriri grave site was unveiled in a ceremony that included government officials, members of Waikato-Tainui and veterans of the battle. A group shot, taken inside the cemetery, depicts Statham on the left hand, one of the few women present at the ceremony, standing next to a man in a fedora who looks remarkably similar to James Cowan [fig. 9]. The various photographs of the day show Minister of Internal Affairs, Richard Bollard, being shown around the trenches by the unnamed Māori veterans along with another of Bollard with Captain Stitchbury, who had escorted the prisoners that day, together with the two unnamed Māori veterans [fig. 9]. The image was a far cry from the enthusiastic handshake between 'old adversaries' James Adam Capper and Hekeria Te Rangi at the Ōrākau commemoration thirteen years earlier [fig. 7]. The Rangiriri restoration was amongst the last of the historical projects for Statham under government contract. In 1928 she reached the maximum age for public service employment and retired. ${ }^{20}$

${ }^{20}$ Phillips, To the Memory, p. 48. 

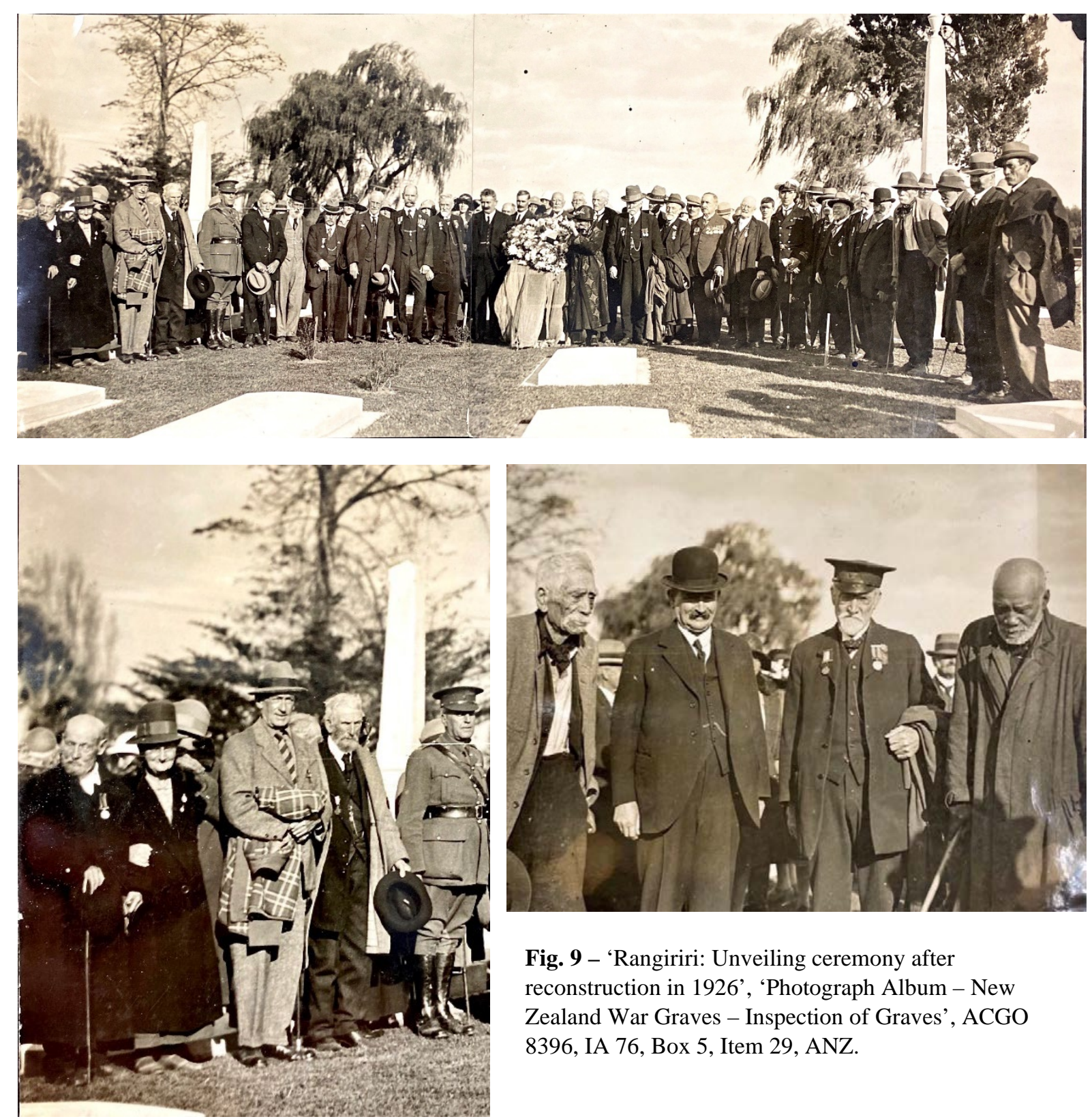

Fig. 9 - 'Rangiriri: Unveiling ceremony after reconstruction in 1926', 'Photograph Album - New Zealand War Graves - Inspection of Graves', ACGO 8396, IA 76, Box 5, Item 29, ANZ.

The end of Statham's contract in 1928 provides an opportune moment to reflect upon the differences in her working relationship with the government compared with Cowan's - a comparison made much more pertinent considering the impact of the history-makers' collective emphasis on martial, masculine ideologies. After a career in junior reporting and making a name for himself as a travel writer and freelance journalist, when Cowan came into a government contract that involved writing an official New Zealand history, he affirmed his position in the realm of professional ethnological and scientific men. This included some of the main players within the Dominion Museum such as Elsdon Best and James Allen Thomson, the latter having spearheaded the Science and Art Act to bring documents of 'scientific, artistic or historical value' together to inform a sense of a collective 
dominion identity. ${ }^{21}$ Cowan, it seems, regardless of where he had come from, was aware of the significance of his professional advancement and would advocate for himself as such. Not only did he feel at ease requesting numerous extensions of his contract to complete the 'valuable' work, he also, in 1920, advocated for his own rise in pay by the same amount that permanent government staff were going to be receiving. ${ }^{22}$ After both volumes of The New Zealand Wars were published, Cowan wrote to the Department of Internal Affairs again, this time requesting $£ 50$ in arrears for the time and money spent putting the last volume through the press after the final termination date of his contract. ${ }^{23}$ In this letter Cowan made a case for his own professional value:

with regard to my application for $£ 50$ extra payment for work done on Vol. II of the History, I wish to point out that any other professional man, a lawyer for instance, would expect payment for extra work done for the government; however deep his interest in the work he could not afford to give the government or any other employer his time for nothing. My position is exactly the same. ${ }^{24}$

Cowan the history-writer was a far cry from the 'foot soldiering' days of his reporting youth. He was now a 53-year-old, successful, respected author and expert, and he expected to be remunerated as such.

The reality for Statham, as a female government worker, was strikingly different. When Statham, who had produced the most widely accessible, physical medium of memory to the nascent New Zealand histories, attempted the same advancement as her male counterparts, she was quickly immobilised. As a member of Victoria League and other women's organisations, Statham had certainly improved the standing of women in the dominion, not by changing gendered notions of women as maternal, natural carers but by shifting the narrative of their essential nature to the collective. ${ }^{25}$ As Marilyn Lake argues, with this shift came new employment opportunities, as once-voluntary positions were professionalised. ${ }^{26}$ But while Statham may have forged a career path within this realm, she had always been focused on a progressive female citizenship with equal entitlement to contribute to national greatness as men could. She did this by preserving the memory of imperial soldier citizens and was selected for a remunerated government contract in 1913, but her experiences under contract were distinctly different from Cowan's five years later. Unsurprisingly, her salary paled in comparison to Cowan, despite being negotiated before the costs of war had started adding up. ${ }^{27}$ Cowan, on $£ 25$ per

\footnotetext{
${ }^{21}$ Science and Art Act, 1913, 4. GEO. V. No. 22;

http://www.nzlii.org/nz/legis/hist_act/saaa19134gv1913n22196/; accessed 26 January 2021; J. Allan Thomson, G. Hogben, 'Organization of Scientific and Industrial Research', AJHR, 2 October 1917, Session I, H-47, p. 7.

22 James Cowan to James Hislop, 14 September 1920, ACGO 8333, IA1, 1280, 4/2/13, ANZ.

23 James Cowan to Mr. Kelleher, 16 January 1924, ACGO 8333, IA1, 1280, 4/2/13, ANZ.

${ }^{24}$ Ibid.

${ }^{25}$ Pickles, 'The Victoria League in New Zealand', p. 31.

${ }^{26}$ Lake, p. 179.

${ }^{27}$ Phillips, To the Memory, p. 45.
} 
month, was on almost 80 per cent more than Statham’s $£ 65$ per annum. ${ }^{28}$ This difference in salary was compounded by the questioning by the Minister of Internal Affairs of Statham's 'competence to control' any additional expenditures associated with the work. ${ }^{29}$ In the same period of time that Cowan was asking for extensions to his contract (and his pay) and asking for raises from Under-Secretary Hislop, Statham's years of tireless work and dutiful monthly reports on the old soldier graves had to be continued voluntarily in Statham's own time outside of work. ${ }^{30}$

Statham's contrasting experience continued into the post-contract years. Appearing to have not lost the 'enthusiasm for the cause', Statham was all too happy to continue her work, even the work that extended beyond the old soldier grave project back into the low paid or volunteer realm. When she reached the age limit for public service employment in 1928, she joined the Auckland branch of the RSA, continuing to focusing on the NZEF memorials, as well as the new graves veterans and those surviving veterans themselves. ${ }^{31}$ Given that she had once been employed by the government to erect and maintain the NZEF memorials, in 1935 she requested government assistance for a 'small allowance of $£ 15$ to $£ 20$ per annum' to merely cover transport to the new grave sites she was responsible for. ${ }^{32}$ The response from the Under-Secretary of Internal Affairs, Joseph Heenan, was telling. To Statham, who asked, ‘surely my services are worth paying something for?' he answered:

so far as the granting of an allowance of $£ 15$ to $£ 20$ this would require the special approval of the Public Service commissioner, and as things are there is no possibility of this. Your assistance in the matter of drawing attention from time to time to any war graves needing renovation is welcomed. I would point out however that such assistance was volunteered by you... It was intimated in earlier correspondence that it was not intended or expected that you should make special visits to cemeteries to inspect war graves. ${ }^{33}$

In pursuit of a progressive female citizenship in the new world, Statham became devoted to the memory of soldiers, as key markers of imperial loyalty and newly configured as the male soldier-citizen for the modern nation. Statham crafted memory and history of these martial political formations that were fundamentally exclusionary of women. In doing so, she embodied the constitutive contradictions of settler colonial progressivism, both uplifted in her work and repressed by it. ${ }^{34}$

\footnotetext{
${ }^{28}$ James Hislop to George W. Russell, 6 December 1917, ‘Contract of James Cowan of Wellington’, 9 March 1918, 8333, IA1, 1280, 4/2/13, ANZ.

${ }^{29}$ James Hislop to George W. Russell, 19 January 1916, ACGO 8333, IA1, 1287, 7/4/2, ANZ.

${ }^{30}$ Phillips, To the Memory, p. 46.

31 J.A. Young to J.A. Mowbray, 29 September 1933, ACGO 8333, IA1, 1661, 32/1/26, 1, ANZ.

${ }^{32}$ Edith Statham to Joseph Heenan, 23 September 1935, ACGO 8333, IA1, 1661, 32/1/26, 2, ANZ.

33 Joseph Heenan to Edith Statham, 1 October 1935, ACGO 8333, IA1, 1661, 32/1/26, 2, ANZ.

${ }^{34}$ Lake, p. 174.
} 
As for Cowan and Statham's old collaborator Robley, the period from 1923 to the turn of the decade looked remarkably different, particularly as Robley seemed to have reached an old age that stimulated reflections on his life and legacy. At the beginning of the decade, Robley began to consider how his legacy might be represented in an obituary hopefully to be written by one of his 'many friends' in New Zealand. ${ }^{35}$ On 19 July 1919, Fildes received a letter from Robley in which he named William F. Gordon, prolific collector of New Zealand war photography and ephemera, as a potential candidate 'one day (soon perhaps)' to be the one to write his obituary. ${ }^{36}$ In another letter to Fildes in October of that year, he listed some of his recent correspondents such as Elsdon Best, Prime Minister William Massey, Colonel Thomas W. Porter and Gilbert Mair, categorising them as 'the obituary friends. ${ }^{37}$ In a letter to Best in June of the following year, Robley reported that Thomas E. Donne had asked him to write a little of his service 'so as to have obituary ready. ${ }^{38}$ Robley partially got his wish in the newspaper special that Fildes had published about him in September 1920. ${ }^{39}$ Furthermore, in 1926, Colonel Thomas Porter published a book entitled Legends of the Maori and Personal Reminiscences of the East Coast of New Zealand, which he dedicated to Robley. ${ }^{40}$

Before Robley was to have any actual obituary written for him, he received other honours in the form of lifetime memberships to both the Tauranga Savage Club in 1923 and to the Polynesian Society in $1925 .{ }^{41}$ The affiliation with the Tauranga Savage Club was significant for the way in which it suggested that Robley had continued an ambiguous relationship with Māori culture like he had when he was collecting mokomokai and Māori antiquities. The Savage Club had been established in London in 1857, after the poet Richard Savage, but quickly became an almost-minstrelsy of its namesake, particularly in the clubs that spread around New Zealand from 1885. ${ }^{42}$ According to Jock Phillips, in what he terms as 'quasi-Māori ritual', leaders of the predominantly Pākehā clubs were referred to as 'rangatira' and 'ariki', with members also dressing up in piupiu and carrying plastic mere. ${ }^{43}$ Robley's behaviour and communication was often illustrative of this 'quasi-ritual'. As far back as 1866, upon his return to England after the wars in New Zealand, Robley was dressing up as 'a Māori chief' and performing the haka for a Victorian Briton audience. ${ }^{44}$ When communicating with his circle of intellectuals in New Zealand in the 1920s, Robley would often refer to himself and them with Māori

\footnotetext{
${ }^{35}$ Horatio Gordon Robley to Maurice Crompton-Smith, 5 October 1929, 'Polynesian Society Correspondence', 80-115-04B/07, ATL.

${ }^{36}$ Horatio Gordon Robley to Horace Fildes, 19 July 1919, FILD0035a, JCBR.

${ }^{37}$ Horatio Gordon Robley to Horace Fildes, 23 October 1919, FILD0035a, JCBR.

${ }^{38}$ Horatio Gordon Robley to Elsdon Best, 18 June c. 1920, MS-Papers-0072-05A, ATL.

${ }^{39}$ Fildes, 'The Maori Wars, Major General Robley: Soldier and Artist', EP, 4 September 1920, p. 9.

40 'Domestic Realm', Gisborne Times, 28 August 1926, p. 4.

41 'The Tauranga Savage Club', BPT, 4 Jan 1923, p. 2; J.C. Adams, 'To the President and the Members of the Council of the Polynesian Society’, 2 November 1925, 80-115-04B/01, ATL.

42 Nigel Cross, The Common Writer: life in nineteenth century Grub Street, (Cambridge: Cambridge University Press, 1985), p. 108; Jock Phillips, 'Men’s clubs', Te Ara; http://www.TeAra.govt.nz/en/mens-clubs/print; accessed 2 June 2021.

43 Ibid.

${ }^{44}$ Walker, 'Robley: Te Ropere 1840-1930’, p. 89.
} 
titles. Elsdon Best was frequently referred to as 'Tohunga Best' and in the lead up to his publication on the wars, Robley addressed Cowan as 'the ariki of the History'. ${ }^{45}$

When Robley was named a life member of the Tauranga Savage Club, a move spearheaded by Gilbert Mair as president, his response was published in the Bay of Plenty Times: 'Dear Mr. President, I received your brightening-up letter announcing my election to your club and I feel so pleased at the compliment. ${ }^{46}$ The following year, an article was published in the Times reporting on a visit from 'Auckland Savages' in a 'memorable day in local savagery. ${ }^{47}$ The article seems to encapsulate many of the fraternal themes of Cowan and Robley's previous incorporations of 'traditional' Māori culture into their work:

In the evening the Aucklanders were the guest of the Tauranga Savage Club at the Coronation Hall which was neatly decorated with flags and photographs depicting Maori Historical Events, from the brush of General Robley of England... [After the welcome] Bro. T. T. Garland was then installed, in accordance with Maori tradition, as Rangatira for the evening's korero. The singing of the National Anthem was followed by a selection by the Tauranga Savage Club's orchestra.... Reverting to more serious affairs, Rangatira Garland had something interesting to say about Savagery, the text of which was as follows: Friendship is the wine of life. Savagery, if it meant anything, was a brotherhood. ${ }^{48}$

Robley's prominence here suggests that he had indeed been a significant creator of visual narratives of a local history, and as a living connection to the New Zealand Wars, stood as a symbol of the martial brotherhood propagated during the Great War. What it also demonstrates is the beginning of Robley's dubious legacy in New Zealand, that has made Robley himself part of a past New Zealand would rather forget.

By the end of the 1920s, perhaps as part of reflections on his own mortality, Robley began to change his tune on not only his significance to New Zealand history but also his relationship with Māori culture, releasing the grip on his 'expert' reputation. In an undated letter to Best from a collection of correspondence from the 1920s, Robley seems to acknowledge the limitations of his work:

Looking over my attempts at "Moko" and now "Pounamu", I consider I was rather conceited to write, when after all I was only a subaltern in NZ for a short time. ${ }^{49}$

\footnotetext{
${ }^{45}$ Horatio Gordon Robley to Horace Fildes, 7 November 1919, FILD00035a, JCBR; Horatio Gordon Robley to Horace Fildes, 1 January 1920, FILD00035b, JCBR; Horatio Gordon Robley, 31 October 1920, MS-Papers11310-11, ATL.

${ }^{46}$ Ibid.

47 'Auckland Savages Visit Tauranga', BPT, 22 September 1924, p. 5.

${ }^{48}$ Ibid.

${ }^{49}$ Horatio Gordon Robley to Elsdon Best, undated, MS-Papers-0072-05A, ATL.
} 
After years of signing off his letters to his New Zealand contemporaries as 'Te Ropere', in a 1929 letter to Polynesian Society council member Maurice Crompton-Smith, Robley signed off as H.G. Robley, and added '("Te Ropere" - that was when I drew Maori). ${ }^{50}$ Which seemed to suggest that Robley, at the end of his life, was noting that he no longer was doing such drawings and that he was now at a distance of space and time to the objects, places and people from which he drew inspiration.

When Robley did eventually die on 30 October 1930, the cable announcing his death was published in at least 22 newspapers across New Zealand. For Robley, who had been so persistent in his desire to create New Zealand local history, the report published in the Auckland Star would have probably been the most satisfactory, had he lived to see it:

Of peculiar significance to the Dominion, the death of M.G. Robley will snap a link with the past that has become part and parcel of New Zealand's young history [my emphasis]. ${ }^{51}$

However, it was in 1931 that Robley finally received the long and considered obituary he had anticipated. Written by the editor of the Journal of the Polynesian Society and Chief Librarian of the Alexander Turnbull Library, Johannes Andersen, the obituary was primarily crafted using the material given to Fildes in 1919 and $1930 .^{52}$ These reports and obituaries suggest that Robley's death was seen, not just as the loss of a tangible connection to a formative part of New Zealand's past, but also as the death of someone who had been instrumental in creating it's historical memory.

While Robley was reconsidering his 'expertise' on Māori topics, Cowan was struggling to reconcile his nostalgic view of Māori within a rhetoric of modernity, particularly when he returned to travel writing for the New Zealand Railways Department from 1927. Unlike his earlier travel writing and to an extent his prominent historical publications of recent years, by this time 'traditional Māori culture' was slightly more difficult to be relegated to an ancient past. Māori themselves for one, were defining their position in post-Great War society in a myriad of ways. The scrupulous work of the Māori Ethnological Board to bring aspects of cultural heritage within a realm of Western progressive intellectualism providing one such example. ${ }^{53}$ Cowan's inability to reconcile a Māori presence in a discourse of modernity whilst also relegating favourable aspects of Māori history to a nostalgia for his childhood is particularly apparent in his 1928 travel brochure, entitled Romance of the Rail. As Lydia Wevers has explored, Cowan's presentation of those rural areas made reachable by the 'strength and power' of modern railways, was often done with his 'inimitable boys-own style, fleshed and coloured

\footnotetext{
${ }^{50}$ Horatio Gordon Robley to M. Crompton Smith, 5 October 1929, 80-115-04B/07, ATL.

51 'Link with Early N.Z.: Death of Famous Maori War Veteran’, AS, 30 October 1930, p. 7.

52 Johannes Andersen, 'Obituary: Horatio Gordon Robley, 1840-1930’, The Journal of the Polynesian Society, March 1931, Vol. 40, No. 1, pp. 39-46.

${ }^{53}$ McCarthy and Tapsell, 'Te Paori Whakapapa', pp. 94-95.
} 
with romantic imagery. ${ }^{54}$ Such style Wevers is referring to glossed those areas and peoples with a nostalgic hue, very much influenced by the childhood Cowan had come to reference time and again. But Cowan's imagery of the modern railway, the means of the visitor's transport to these places, was that of an 'image of conquest' reminding the reader and visitor of what is being 'conquered. ${ }^{55}$ Wevers suggests that these 'countervailing rhetorical currents' make it almost 'impossible to know what his primary objective is - to mourn the lands of mystery and the heroes of the past or to celebrate the arrival of the conquest?' 56

While the brochure grapples with this duplicity, it does away with any suggestion that the dynamic is symptomatic of anything more serious when in the chapter entitled 'New Zealand, Wonderland of the Pacific', Cowan states: 'There is no racial problem whatever. Peace between the new settlers and the Natives was firmly established half a century ago. ${ }^{57}$ The brochure ultimately promotes visits on the basis of the allure of the comparatively 'untouched landscapes', imbued with a history inextricably tied to Māori authentic culture. Brendan Hokowhitu has described this type of dynamic as a sort of neocolonial 'Disney Fantasyland - a timeless childlike world, free from the hegemony of the powerful adult. ${ }^{58}$ Cowan's presentation of modern train travel into this kind of fantasyland fosters a sense of paternalistic observance of authentic Māori culture that allows 'colonial guilt to remain in the unconscious. ${ }^{59}$ This is not to say that Cowan did not support measures to allow for Māori development economically. As his economic report on 'the Maori' from 1930 suggests, Cowan believed the Māori land needed to be secured from any further dispossession and Māori should be supported in developing their lands for agricultural and other purposes. ${ }^{60}$ But even this did not appear to challenge a rendering of Māori that fitted within a nostalgic image of Māori and their industry in his childhood on the aukati border. The modernity of the 1920s and the aspirations of those such as Ngata and the Board, Te Puea Hērangi and Tahupōtiki Rātana signalled a divergence from Cowan's understanding of a local New Zealand past and the place of Māori in it.

After the death of Statham's former collaborator Robley, and while Cowan continued to grapple with how to position Māori in his writing, Statham was back in Auckland as Honorary Inspector of Graves for the RSA, where she was now able to continue the historical work she enjoyed, even if it was unpaid. This time, however, would bring new concerns for how to remember the past at a time when New Zealand society was looking forward from the grief of the Great War. For Statham, whose

\footnotetext{
${ }^{54}$ Wevers, 'Romance of the Rail’, p. 45.

${ }^{55}$ Ibid.

${ }^{56}$ Ibid, pp. 45-46.

57 James Cowan, Romance of the Rail: Through the Heart of New Zealand: The North Island Main Trunk Railway: A Descriptive and Historical Story, (Wellington: Govt. Printer, 1928), p. 59.

${ }^{58}$ Hokowhitu, ‘The Death of Koro Paka: “Traditional” Māori Patriarchy’, p. 128.

59 Ibid.

${ }^{60}$ James Cowan, The Maori: Yesterday and To-Day, (Christchurch: Whitcombe \& Tombs, 1930), p. 17-18.
} 
memorialising work dealt directly with the topic of death and burial, continuing remembrance would mean needing to consider how the past was framed within the forward, hopeful momentum of modernity. The rise of functional memorials to the Great War dead from 1919, in the form of new urban, memorial buildings and facilities, had already demonstrated how to delicately balance remembering with a sense of moving forward. ${ }^{61}$ But back in Auckland in the 1930s, Statham was pushed to try and apply something similar to the graves of the locally buried soldiers and pioneers of the colonial past.

Unlike those utilitarian Great War memorials to the dead in foreign lands, Statham was having to reconceptualise the place of old grave sites in the modern urban city. The turn of the century was a time when many of the cemeteries which had been used during the New Zealand Wars and pioneering period were starting to reach capacity. Most pertinent was Symonds Street Cemetery which was officially closed by the Auckland (Symonds Street) Cemeteries Act 1908, though the Act included provisions for any outstanding family plots or exceptions for further burials. ${ }^{62}$ Symonds Street had been a foundational focus for the Victoria League’s Auckland Branch and central to Statham's initial work, primarily for those New Zealand War soldiers and sailors buried there. ${ }^{63}$ It was however, increasingly taking on an aura of genesis as Auckland City developed, particularly as it was the resting place of 'pioneers' such as Governor Hobson, merchant James Williamson and Colonel George Dean-Pitt. At least that was who Statham and President of the Victoria League J.A. Mowbray cited when in 1934 and 1935 they approached the Minister of Internal Affairs to report that the graves had fallen into disrepair yet again. ${ }^{64}$

In 1934, the complexities around how do deal with the crumbling gravestones were largely the same as in 1910 but the resolutions discussed were decidedly different. Statham and Mowbray had initially been in contact with then Under-Secretary Malcolm Fraser, who had shut the matter down in August $1934 .{ }^{65}$ When the new Under-Secretary Joseph W. Heenan took up the position in April 1935, Statham approached him with the matter. ${ }^{66}$ Similar to her arguments in her early work, Statham was concerned with the fact that the records for the Symonds Street Cemetery had perished in a fire and that the information that was engraved on the headstones was the only record available to remember the buried by. ${ }^{67}$ At this point Statham still appeared to be focused on preserving individual graves stones as they were. The Symonds Street Memorial had been erected down the road in 1920, but this had been in addition to the preservation measures of the gravestones in the cemetery, not instead of them. ${ }^{68}$

\footnotetext{
${ }^{61}$ Phillips, To the Memory, p. 93.

62 Auckland (Symonds Street) Cemeteries Act, 1908, 8 EDW VII, No. 12; http://www.nzlii.org/nz/legis/hist_act/asca19088ev1908n12486/; accessed 22 May 2021.

63 J.A. Mowbray to J.A. Young, 9 February 1934, 'War Graves - Cemetery - Symonds St', ACGO 8333, IA1W1893, Box 3, Record 7/4/11, ANZ.

${ }^{64}$ Ibid; Edith Statham to Joseph Heenan, 16 September 1935, ACGO 8333, IA1W1893, 3, 7/4/11, ANZ.

65 Malcolm Fraser to Edith Statham, 1 August 1934, ACGO 8333, IA1W1893, 3, 7/4/11, ANZ.

${ }^{66}$ Edith Statham to Joseph W. Heenan, 29 May 1935, ACGO 8333, IA1W1893, 3, 7/4/11, ANZ.

${ }^{67}$ Edith Statham to Joseph W. Heenan, 9 October 1935, ACGO 8333, IA1W1893, 3, 7/4/11, ANZ.

68 J.G. Ward to Edith Statham, 15 January 1912, Ephemera (Loose), Boxes 1, 4, 14, 15, NZMS 1244, GGSC.
} 
Statham was not afraid of the idea of a common memorial such as an obelisk, as a cost-effective way to replace crumbling headstones and retrieving the names of the men before they deteriorated forever. ${ }^{69}$ However, this was not as easy a task as it had been with imperial soldier graves, as many of the families of those buried at Symonds Street were still local and visiting the cemetery regularly. In a letter from the Town Clerk to Heenan on the matter, the Clerk pointed out that when the prospect of an obelisk for the remaining non-soldier graves was put forward in 1920, much objection had been raised by the families. $^{70}$

In line with both her Victoria League and government work, whether it be individual gravestones or a cost-effective obelisk, Statham continued to push Heenan to subsidise the renovation project. After multiple letters from Statham during his first year, Heenan was reluctant to provide expenses. In the midst of a financial depression, Heenan argued that his Department had already expended $£ 600$ on the Symonds Street graves and he wanted the Auckland Council to take more responsibility in the matter. ${ }^{71}$ Finally in October 1935, Heenan wrote to Statham to let her know that it was not at all possible for the Department to expend $£ 100$ for the work within the current financial year, but that the matter would be reviewed again 'early in the New Year.' ${ }^{72}$ Statham relented, but was not prepared to waste any time. Eight days into 1936 she sent another letter to Heenan enquiring on the matter: 'you stated that the matter would be discussed in early January. I am now writing to ask if you will kindly inform me whether anything has been decided about the matter. ${ }^{73}$ Heenan, slightly impatient with Statham at this point responded: 'I stated that this matter would again be considered early in the New Year not early January. In view of the change of government and... owing to more important matters of policy... This matter must perforce in abeyance a little longer [emphasis in original]. ${ }^{74}$ Statham backed down at this point, stating that she would 'defer any further correspondence' until she heard from him again. ${ }^{75}$

Not keeping to her word, in April 1936 Statham wrote to Heenan yet again, this time drawing upon the centennial focus of Heenan and the new Labour government. ${ }^{76}$ But this time she included a letter to the editor of the New Zealand Herald that she wished to draw Heenan's attention to, which read:

\footnotetext{
${ }^{69}$ Edith Statham to Joseph W. Heenan, 9 October 1935, 19 July 1938, ACGO 8333, IA1W1893, 3, 7/4/11, ANZ.

70 Town Clerk, to Joseph Heenan, 30 July 1935, ACGO 8333, IA1W1893, 3, 7/4/11, ANZ.

71 Joseph Heenan to Edith Statham, 6 August 1935, Joseph Heenan to the Town Clerk, 6 August 1935, ACGO 8333, IA1W1893, 3, 7/4/11, ANZ.

72 Joseph Heenan to Edith Statham, 7 October 1935, ACGO 8333, IA1W1893, 3, 7/4/11, ANZ.

${ }^{73}$ Edith Statham to Joseph W. Heenan, 8 January 1936, ACGO 8333, IA1W1893, 3, 7/4/11, ANZ.

${ }^{74}$ Joseph Heenan to Edith Statham, 13 January 1936, ACGO 8333, IA1W1893, 3, 7/4/11, ANZ.

${ }^{75}$ Edith Statham to Joseph W. Heenan, 15 January 1936, ACGO 8333, IA1W1893, 3, 7/4/11, ANZ.

${ }^{76}$ Rachel Barrowman, 'CCulture-organising' Joe Heenan and the beginnings of state patronage of the arts', JNZS, Vol. 6, No. 2, 1996, p. 6.
} 
Sir - Kindly allow space for a few remarks on the cemeteries in Symonds Street, where rest many of Auckland's early citizens and pioneers... It is high time the controlling authorities initiated some plan for transforming these cemeteries into park areas. If a commencement were made now the citizens of today might hope to see these cemeteries turned into beautiful and attractive environs of the city before the centenary celebrations in $1940 .{ }^{77}$

Heenan was interested in the idea, as he stated he had also seen a few examples of old closed cemeteries laid out as public parks in the 'Old Country." ${ }^{78}$ Statham concurred by insisting that 'laying out the cemetery as a park' was something she had tried to get done for many years, and would be glad if her suggestions would be 'carried into effect later. ${ }^{79}$ Statham was put in contact with the Inspector of Parks right away about the concept, but was snapped back to the reality of the concerns of family members of those buried on site, when just over two months later she received a complaint from a family member about the conditions of an individual head stone. ${ }^{80}$ The matter seemed to have been dropped by April 1937 when Heenan finally approved the $£ 100$ funding for the renovation work of the individual graves. ${ }^{81}$

However in July 1938, there appeared to have been a meeting of the City Council at which a city engineer, Mr Tyler, presented a scheme to convert the Symonds Street cemetery into a public park. ${ }^{82}$ Perhaps further heightened by ongoing construction of the Grafton Bridge encroaching on the site, ${ }^{83}$ the proposed scheme created an uproar in the newspapers. On the one hand, the prospect was considered disrespectful and desecrating. One letter to the editor signed as 'relative' wrote into the Auckland Star in August:

Even the heathen had respect for the graves of their dead, yet here in our Christian community the city engineer proposes to turn consecrated cemeteries into a public park, removing enclosing walls and memorial stones and leaving the graves of our beloved dead to become part of a lawn. $^{84}$

Another article published in the New Zealand Herald the same day, highlighting the involvement of the Auckland Fine Arts Committee, also dispelled the idea that those involved would go forth without

\footnotetext{
${ }^{77}$ D.P. O’Leary, Letter to the Editor, NZH, 19 April 1936, in Edith Statham to Joseph W. Heenan, 20 April 1936, ACGO 8333, IA1W1893, 3, 7/4/11, ANZ.

78 Joseph Heenan to Edith Statham, 23 April 1936, ACGO 8333, IA1W1893, 3, 7/4/11, ANZ.

${ }^{79}$ Edith Statham to Joseph W. Heenan, 30 April 1936, ACGO 8333, IA1W1893, 3, 7/4/11, ANZ.

${ }^{80}$ Edith Statham to Joseph W. Heenan, 7 August 1936, ACGO 8333, IA1W1893, 3, 7/4/11, ANZ.

81 Joseph Heenan to Edith Statham, 15 April 1937, ACGO 8333, IA1W1893, 3, 7/4/11, ANZ.

82 'City Cemeteries', NZH, 23 July 1938 ACGO 8333, IA1W1893, 3, 7/4/11, ANZ.

${ }^{83}$ Edith Statham to Joseph Heenan, 9 July 1937, ACGO 8333, IA1W1893, 3, 7/4/11, ANZ.

84 'Symonds St Cemetery’, AS, 11 August 1938, ACGO 8333, IA1W1893, 3, 7/4/11, ANZ.
} 
consulting 'surviving relatives and the religious organisations.' ${ }^{85}$ There were also very positive reactions to the idea. One respondent, V.L. Jackson, wrote:

On several visits lately, I have failed to find a relative's grave, and I suppose the same would apply to 50 per cent of the younger generation. In its neglected state the cemetery is very unsightly; nobody cares to visit it, and its gloomy surroundings leave one much depressed. Why not make the place brighter and more attractive? ${ }^{86}$

Statham's support for the initiative suggested that she was continuing to try and install the same generative remembrance for the settlers and soldiers of the colonial past, as had been done with Great War memorial buildings. But in this instance, Statham's attempt to have remembrance for the dead in a democratic, modernist fashion of the memorial park conflicted with the way in which many of the families had wanted to mourn their dead as individuals in a family plot. While the scheme never came to fruition, the example illustrates how Great War remembrance of the thousands of fallen soldiers in distant battlefields tended to serve New Zealand as a modern progressive nation more so than the dead of a settling past who were buried locally.

As for Cowan during this 1930s period, he too continued to look at the new ways to transform the colonial past into positive, cohesive aspirations for the future of New Zealand historical memory. As Wevers argues, Pākehā naturalisation and claims to nativism are most frequently fostered through connections of childhood and landscape, innocence and space. ${ }^{87}$ This was certainly true of Cowan's own sense of self as a New Zealander, so it is no wonder that his next move was to provide the same for young New Zealanders. Cowan's payments from the government to write on 'Maori history' had ended in 1930, but his publications thereafter continued to focus on Māori topics. ${ }^{88}$ In 1930, Cowan republished a revised edition of his 1910 publication The Maoris of New Zealand, this time entitled The Maori Yesterday and Today. With the publication of Tales of the Maori Coast in 1930, Legends of the Maori written collaboratively with Sir Maui Pomare in 1930-1934, and Tales of the Maori Bush in 1934, it appeared Cowan was favouring the anthology format of Māori-focused folkloric stories. In 1935, Cowan published Hero Stories of New Zealand, a seemingly more universal title, that included a mixture of Māori and Pākehā 'adventure stories', many of which were moments of the New Zealand Wars repurposed as adventurous tales. ${ }^{89}$ Thomson Leys had prophesised the direction Cowan would take in fostering a sense of homemade heroism back in 1918 when he suggested that 'the New Zealander

\footnotetext{
85 'Old Cemetery, Symonds Street Areas: Statement by Mayor’, NZH, 11 August 1938, ACGO 8333, IA1W1893, 3, 7/4/11, ANZ.

${ }^{86}$ V.L. Jackson, 'Symonds Street Cemetery', NZH, 13 August 1938, ACGO 8333, IA1W1893, 3, 7/4/11, ANZ.

${ }^{87}$ Wevers, 'Being Pakeha', p. 4.

88 'Payments to James Cowan for Writing Official Maori History and Articles for Publications', 1934, ACGO

8333, IA1, 1280, 4/2/13, ANZ.

${ }^{89}$ James Cowan, Hero Stories of New Zealand, (Wellington: Harry H. Tombs Ltd, 1935), pp. xiii-xiv.
} 
of the future should be proud of the courage, enterprise and self-reliance of the pioneer settlers as the Americans today are of the heroes of the Revolution. ${ }^{90}$ Besides the fact that this painted any Māori opposition in a pretty dubious light, this American comparison was a strong feature of Cowan's work, particularly in Hero Stories. In the preface Cowan writes:

If ever there was a country that developed the spirit of the frontier it was New Zealand, Explorers, Scouts, bush-fighters, frontier settlers we have had in multitude, men (and women, too) who lived adventurous days and nights and suffered and endured. I know many men who were as well entitled as any hero of America's West to the title of frontiersman, men who lived wild days on the border... British troops fight their slow way against the Maori on his native fern-heath and in his stockades; the gold seekers who carried their swags through icy torrents and over snowy mountains in a wilder land than California - the sum of their efforts would seem to have constituted a true epic of conquest and colonisation. ${ }^{91}$

For Cowan, having 'addressed' the history of colonial conflict, that history could now be told as romantic adventure stories. In this new historical genre the only threat to national unity was having a new generation look elsewhere for patriotic adventure stories.

Cowan did not state that Hero Stories was indeed geared towards an adolescent readership, but one year later he returned as a regular columnist at the Auckland Star, this time producing a weekly article for the children's supplement entitled Enzed Junior. ${ }^{92}$ According to Kathryn Parsons, the supplement was designed to be a collectable that children in the Greater Auckland area could keep in binders, and there is evidence to suggest that children did just that. ${ }^{93}$ One of Cowan's first stories in Enzed Junior was entitled 'Boy Heroes of New Zealand', which according to Parsons was drawn directly from Hero Stories. ${ }^{94}$ Cowan started the article setting up a sense of a typical New Zealand boyhood:

The history of New Zealand, and particularly the adventurous contact between the two races, Pakeha and Maori contains many a dramatic incident in which a boy has played a man's part and distinguished himself by his courage and resolution and self-reliance when most lads would be at school. ${ }^{95}$

Tailoring his reference points to the adolescent reader, Cowan went on to describe Māori boys who (in traditional martial fashion) had started on the war path as early as twelve. Against this backdrop of war

\footnotetext{
90 Thompson W. Leys to George W. Russell, 1 February 1918, ACGO 8333, IA1, 1280, 4/2/13, ANZ.

${ }^{91}$ Cowan, Hero Stories of New Zealand, p. viii.

92 Kathryn Parsons, ““A Famous Writer Coles to Our Pages”: James Cowan's Children's Writing for the Enzed Junior', JNZS, No. 19, 2015, p. 98.

93 Ibid, p. 101.

${ }^{94}$ Ibid.

95 James Cowan, ‘Boy Heroes of New Zealand’, Enzed Junior, 5 February 1936, p. 196; ‘Assorted clippings relating to Maori culture and New Zealand history’, fMS-Papers-11310-184, ATL.
} 
faring so inherent it started in childhood, Cowan went on the describe 'the white boy's hard schooling', pioneer boys being required to take up weapons at a similar age. ${ }^{96}$ In doing so he transported the ideas from his earlier works, to a children's realm, that rugged Pākehā masculinity was both in the name of respect for 'traditional' Māori hypermasculinity and sharpened by the experience of opposing it. Aside from tailoring the theme and message to an adolescent audience, Cowan's vocabulary in his contributions were relatively unchanged from the publications he had produced earlier for an adult readership. ${ }^{97}$ Which appeared to say more about Cowan's regular style of writing than they did about the capacity for adolescent readers to understand big concepts of war and violence. There appeared to be a dual process of remembering and forgetting in these historical stories fashioned for children: to remember the martial, masculine values set forth by the conflict of settlement but also to forget the trauma, death and raupatu that also occurred as part of this 'adventuring contact.'

In this late part of his life, Cowan gained some influence in this more adolescent, pedagogical realm. It is unclear whether it was due to the Enzed Junior weekly articles Cowan had been publishing since January 1936, but in September of the same year he received a letter from Patricia Moore, a student at Epsom Girls Grammar. ${ }^{98}$ In the letter, addressed to the Librarian of the House of Representatives to forward to Cowan, Moore informed Cowan that her class had been tasked with writing a book 'concerning Maoris.' As Moore had grown up in the King Country, she told Cowan she had wanted to focus on the 'History and Legends of the King Country.' Not only was the request indicative of his influence in schools, the letter from a young person eager to know more about culture of the environment in which she was reared seemed to have an impact on Cowan as it was the only letter of its kind included in a group of correspondence with his 'friends. ${ }^{99}$ When Enzed Junior eventually folded in May 1941, owing to the ongoing cost of the Second World War, the editor in his parting message singled out Cowan for his contribution, writing:

Perhaps we should give an extra special cheer to Mr. James Cowan who for many years now has for our benefit dipped into that vast treasure house of knowledge and memories that is his alone. "Jimmy Cowan" as he is affectionately known in this country which he loves and knows so well, is a living history book. He has seen New Zealand grow from a colony to a nation and what is even more valuable is he has remembered and noted... Few people have done so much to depict Maori as he is without romance or sentimentality, and perhaps no one has ever written history in such an enthralling and charming way. Reading a Cowan article is like sitting by a

\footnotetext{
96 Ibid.

${ }^{97}$ See series of article examples in fMS-Papers-11310-184, ATL.

98 Patricia Moore to James Cowan, 14 September 1936, MS-Papers-11946-173, ATL.

99 See series of letters at MS-Papers-11946-173, ATL.
} 
fire on a winter's night and listening to "Jimmy" himself telling a tale of great warriors of the fern hills of long ago. ${ }^{100}$

Being labelled as a 'living history book' must have been a satisfactory moment for Cowan whose personal experience and nostalgia had always been so central to his work. The claim that Cowan had not depicted Māori as sentimental and romantic in his 'entralling and charming' histories, speaks to the obscurative power of Cowan's depictions of the settling past.

Cowan's attempts to inculcate a sense of nativism amongst Pākehā children was further emphasised through a series of correspondence with Frank Combs at the Department of Education and E.S. Andrews at the National Education Institute. In a letter from Combs to Cowan in November 1937, Combs referenced that Cowan had sent him copies of Hero Stories of Old New Zealand and The Old Frontier, which he 'greatly appreciated.' ${ }^{101}$ Combs' responsibilities at the Department of Education included assisting in the publication of books that would give children an understanding of their national heritage, as well as textbooks, bulletins and handbooks for students. He had also been involved in enlivening the New Zealand School Journal. ${ }^{102}$ Cowan, it seems, had approached Combs about having Hero Stories be made available as a school resource, to which Combs agreed:

If what I am doing in the Education Department develops New Zealand writers, particularly those of your own sterling character, can look to me to do my utmost not for them but for New Zealand literature which, of course, ought to be the lifeblood of local feeling and imagining. "Hero Stories of New Zealand" I quite agree is a book [that] copies of which ought to be in every school. I will continue to do what little I can to have it recognised. ${ }^{103}$

A similar stance was taken by Andrews who was in correspondence with Cowan about an article of his to be published in the Education Institute Journal in February 1938. Speaking of Cowan's article which was to do with King Tāwhiao, Andrews requested Cowan keep in the text the jovial praise of Tāwhiao ('to hooray') as he was trying to ban 'finicky, pedantic English from the pages of "National Education", to give it some of the tang of the best local speech and in doing this, you [Cowan] I am sure can be a tower of strength.' ${ }^{104}$ Andrews went on to request that Cowan ensure that every article he provided from there on out have 'plenty of the meat of history - stuff that they can directly hand to children.' ${ }^{105}$ It is difficult to quantify just how much influence Cowan had on those charged with creating school curriculums and designating resources. But what his correspondence with Combs and Andrews demonstrates is that Cowan had a reputation for being a central figure of a more general movement to

\footnotetext{
100 ‘And So, Au Revoir!’, Enzed Junior, 31 May 1941, p. 1, fMS-Papers-11310-184, ATL.

${ }^{101}$ Frank Combs to James Cowan, 17 November 1937, 'Inward Correspondence', MS-Papers-0039-01A, ATL.

102 William Renwick, 'Combs, Frank Livingstone', DNZB, Te Ara, 1998;

https://teara.govt.nz/en/biographies/4c27/combs-frank-livingstone; accessed 22 May 2021.

${ }^{103}$ Frank Combs to James Cowan, 17 November 1937, MS-Papers-0039-01A, ATL.

${ }^{104}$ E.S. Andrews to James Cowan, 22 February 1938, MS-Papers-0039-01A, ATL.

105 Ibid.
} 
pedagogically break away from old world sentiments. In Cowan's correspondence at the time, the emphasis appears to be not on remembering the realities of colonial conflict but remembering colonial conflict to create a sense of locality. But of course, a full and effective memory of the conflict would be to challenge the territorial right to that locale.

By the end of the decade, Cowan returned from a focus on the nativism of New Zealand children to another exploration of his own in his 1940 publication, Settlers and Pioneers. The publication provided much of Cowan's nostalgic renderings of his childhood home as part of the settlement in the Waikato. It was in this publication that Cowan provided his description, as included in chapter one: 'the first home I knew, the first trees and the first flowers, were on the soil that had less than ten years before been a battlefield. ${ }^{106}$ The publication was a part of the Centennial surveys, commissioned by the Department of Internal Affairs as a part of the 1940 centennial celebrations. When Cowan's manuscript arrived, it was labelled by a member of the Centennial Publication staff as a 'wildly episodic bundle of papers', referring to the anthological form of Cowan's historical writing at this time. ${ }^{107}$ The publication marked the moment that Cowan's nostalgic, adventuring style of history was being overtaken by new modern forms of historical scholarship which emphasised professional distance between the past and the historian. ${ }^{108}$ In some ways, Cowan had already been creating this distance, through his portrayal of the colonial past as being resolved in the present. But the centrality of his personal experience and nostalgia would be the undermining factor of his credibility in the new realm of the modern, professional historian.

\footnotetext{
${ }^{106}$ Cowan, Settlers and Pioneers, p. 44.

${ }^{107}$ D. O. W. Hall, "Mr Cowan's Survey," 8 September 1939, IA1, 62/110/2, ANZ, as cited in Hilliard, 'Stories of an Era Not Yet So Very Remote', p. 29.

${ }^{108}$ Belgrave, p. 59.
} 


\section{Conclusion}

Together, the histories of James Cowan, Edith Statham and Horatio Gordon Robley created a memory of the most contentious moments of New Zealand's colonial past. The histories came together primarily within the period between 1914 and 1923, and as this thesis has demonstrated, their shared focus on telling the story of colonial conflict came through a long period of activity in different spheres. Through their different 'theatres of memory', public space, print media and the museum, the three history-makers selected figures and events from the past to secure a sense of 'history' for the future. In doing so, Cowan, Statham and Robley's work reflected the tension of the settler colony to create a culturally distinct national locale, as well as nurture the cultural relationship with the imperial old world. Their coalescing historical work often did both, distinguishing the settler past by proximity to Māori and an intimate relationship with landscape, then drawing Māori into imperial definitions of valour and respectability. The nascent histories of Cowan, Statham and Robley were fundamentally contradictory to the modernity and progress of New Zealand, and for this reason they were not able to create an ongoing culture of historical remembrance. Their histories came to be forgotten, lapsed into a national forgetfulness. As this thesis has demonstrated, their historical work often contributed to the cultural forces that led to such forgetting.

The first chapter delineated how settlement was part of their biographical formation, particularly for Statham and Cowan who each had contrasting experiences of settlement in New Zealand from childhood. Statham's experience in the rapidly growing settlement of Dunedin from 1863 exemplified some of the key concerns of those settling in the area. Marked by its mineral wealth and relatively sparse indigenous population, Dunedin society was better able to create an idealistic, progressive new world settlement, by spearheading new age political movements such as woman's suffrage. It was in this realm that Statham as a single, economically independent woman gained her organisational stride and later emboldened her idea of progressive female citizenship by contributing to imperial and national patriotic efforts. For her contemporary Cowan, who was born in 1870 and raised on the embattled Waikato frontier, new world settlement was defined through entirely different means. Before Cowan was born, settlement in the Waikato was marked by its lack of success. The scheme to promote military settlement and establish farmland had largely failed, standing in stark contrast with the remnants of Māori industry across the aukati border. Settlement in this context involved the managing of old threats and previous failings, establishing at the very least a cordial relationship with Māori who once fought against a settler colonial presence, and successful agriculture on the land being settled. These contrasting colonial experiences formed Statham and Cowan's later attempts to create a colonial memory for the New Zealand collective. 
The subjectivity of any individual effort to foster a sense of a collective memory is apparent in the colonial experience of both Cowan and Robley. Particularly given that their own later recollections of their colonial experiences form a significant part of how we have come to know those experiences. In these recollections and secondhand records of the time, Robley and Cowan were much more intimately involved in the colonial conflicts with Māori than Statham was in Dunedin. Robley's inroad to New Zealand was as a soldier in the British Army in 1864-66. His time in New Zealand was only temporary, but in those two years in the colony, Robley became immersed in Māori culture. It was this proximity that allowed him to see ethnological truths about his collection of mokomokai that supposedly no one else could. In doing so, Robley joined the ranks of Pākehā artists and ethnographers attempting to salvage the remnants of what they saw as fast disappearing authentic Māori culture. Cowan's reminiscences of his colonial experience, on the other hand, served to resolve those struggles of Waikato settlement. In his colonial experience, Māori and Pākehā lived harmoniously though not without knowledge of prior tensions, and despite his father's apparent bankruptcy, Cowan recalled his family farm as being more successful and productive than those of the initial military settlement scheme. Like Robley, this proximity served Cowan at the time, when he moved to Auckland in 1888 to become a journalist covering 'Māori affairs.' Cowan and Robley’s accounts hold greater meaning later, but the proximity with Māori they emphasise was also being affirmed in their immediate engagements into the new century. Their accounts of their colonial experience both explain why they had confidence in their expertise on Māori subjects and exemplify how confident they would become in those credentials.

The second chapter explored how Cowan, Robley and Statham collectively demonstrated the 'entanglement' of national and imperial belonging in their work from 1901 to $1914 .{ }^{1}$ According to Jane Stafford and Mark Williams, in this time period 'Maoriland merged with a mood of imperial enthusiasm that lead to war.' ${ }^{2}$ The culture of Maoriland continued to draw on Māori art and imagery to create a cultural locale, while the death of Queen Victoria in 1901 and the end of the Anglo-South African War in 1902 both reaffirmed a sense of imperial duty and belonging to the wider empire. 1901 also saw the passing of the Māori Antiquities Act. Spearheaded by Native Minister, James Carroll, the Act marked a change within the discourse of Maoriland. Robley's offer to sell his collection of mokomokai to the New Zealand government, while in line with the stipulations of the Act, was rejected by Carroll. The rejection of the collection along with the response from Pākehā New Zealanders served as an important point of divergence within Maoriland between the opportunity to advance and protect Māori interests and the continued accelerating use of their imagery by Pākehā at the same time. Cowan himself took part in this acceleration through his work at the Department of Tourist and Health Resorts, turning Maoriland into a wonderland for the 'pleasure-seeking' international tourist, prospective settlers, and

\footnotetext{
${ }^{1}$ Hunter, 'National and Imperial Belonging in Wartime', p. 32.

2 Stafford and Williams, p. 11.
} 
wealthy New Zealanders. ${ }^{3}$ His 1907 publication of New Zealand or Ao-tea-roa was included in the collections of travel literature on offer at New Zealand House in London, contributing to the construction of the new Dominion within the metropolitan space. Robley, operating from the metropolitan space, also continued to produce Māori imagery for a predominantly non-Māori audience through his foray into the new prolific medium of the picture postcard.

The Edwardian picture postcard, used by Robley to apply Māoriland distinction to the Dominion from his metropolitan perspective, was also indicative of intimate relationships between those in the Dominion and those in the British homeland. As Katie Pickles has demonstrated, the Victoria League was another influential proponent of fostering 'friendliness' and enduring attachments with Britain. ${ }^{4}$ As a mainstay at the Auckland branch of the League, Statham was a champion of this cause. It was within this discourse of strengthening imperial ties that Statham sought to bring the 'incidents of the wars in New Zealand' into historical understanding. Statham was concerned primarily with marking the graves of those who fought for empire in New Zealand, as had been done by her contemporaries in South Africa after the end of the Anglo-South African War. The work appeared as a part of Statham's pursuit of a progressive female citizenship by conducting her duty of ensuring the remembrance of the imperial soldier-citizen. The remainder of Statham's work with the League, particularly focused on the Symonds Street memorial to the Imperial and Colonial forces, and the 'friendly Maories', reflected both a public and governmental desire to resituate New Zealand's colonial past within an imperial narrative. These efforts indicated the strength of imperial fervour in New Zealand in the lead up to another war for empire in Europe. The second chapter ultimately demonstrated that fostering a cultural, national locale and reinforcing belonging to empire were strong, coexisting forces during this 1901-1914 period. Both impacted the view of New Zealand's past as well as how New Zealand would aide empire when the Great War commenced.

Chapter three charted the period during and after the Great War when all three of the historymakers focused on the wars of the colonial past and began to organise the events into a crafted historical narrative. From 1914, Statham continued her work refurbishing old soldier graves, this time as a government employee, Robley's water colours had been put on display at the Dominion Museum and Cowan was a freelance reporter, soon-to-be government historian. Operating from these distinct 'theatres of memory' of public space, the museum and print media, the combined work of the three history-makers appears as a nexus of memory. Each had a unique objective to shape the collective memory of New Zealand's colonial past. By this point in time, Cowan and Robley had caught up to Statham's incorporation of people of the colonial past into an imperial tradition. They had witnessed

\footnotetext{
${ }^{3}$ McClure, p. 57.

${ }^{4}$ Pickles, 'The Victoria League in New Zealand', p. 30.
} 
New Zealand's distinction in the fight for empire and looked to the colonial past to validate the martial, modern and masculine values of New Zealand's Great War forces.

All three history-makers negotiated the inclusion of Māori who had not fought for empire into their narratives. This was particularly difficult for Statham whereas Cowan and Robley, long participants of Maoriland discourses, took to the task more naturally. The key was to select those Māori figures such as Rewi Maniapoto at Ōrākau and Rawiri Pūhirake at Te Ranga whose 'patriotism' for the Māori cause and honourable treatment of the imperial and colonial opposition could be incorporated into romantic historical storytelling. For Cowan and Robley, drawing certain Māori figures into a narrative of admiration also involved drawing Anglo-settlers into a comparable realm. There was a need in this dualistic relationship, to present a martial predisposition for violence in the Māori opposition which the more 'noble' among them could contain and channel into respectable soldierly behaviour. The idea of Māori as innately warlike also gave the Anglo-colonials who had fought against Māori and alongside them a sense of comparable martial capacity. In Cowan, Robley and Statham's nexus of memory we see how historical narrative was employed to affirm what Brendan Hokowhitu has identified as the 'hybridisation of Māori masculinity and British patriarchy.' 5

As a progressive woman of the new world whose pursuit of that ideal led her to commemorating imperial soldiers, Statham embodied the dichotomy of belonging in New Zealand. The contradictory nature of Statham's work was further demonstrated in the final chapter through an analysis of how her experience working with the New Zealand government contrasted with that of Cowan's. Having spearheaded the imperial style of remembrance that would come to be utilised in the memory boom of the Great War from when she was with the Victoria League in 1910, Statham was an important figure in New Zealand's early culture of commemoration. But when she attempted to negotiate further government assistance in her memorial and grave care work in Auckland her entitlement to such assistance was denied. Not only did Statham reflect New Zealand's dichotomous sense of belonging, she also highlighted the contradictory nature of settler colonial progressivism, both uplifted by its policies and repressed by its cultural values. ${ }^{6}$

The final chapter charted the contextual changes effecting the work and reflections of the three history-makers, in the years that followed Cowan's The New Zealand Wars publication. The 1920s saw the establishment of the Board of Māori Ethnological Research, an example of what Marilyn Lake has identified as 'indigenous progressivism calling settler colonialism to account. ${ }^{77}$ The Board, gradually steering the study of Māori subjects away from the control of Pākehā experts such as Cowan and Robley, was not the only catalyst for change impacting the history-makers' work. But it does indicate the beginning of what would be a disillusionment with Cowan and Robley's nostalgic hue. Robley

\footnotetext{
${ }^{5}$ Hokowhitu, ‘The Death of Koro Paka: “Traditional” Māori Patriarchy', p. 134.

${ }^{6}$ Lake, p. 5.

${ }^{7}$ Ibid, p. 224.
} 
himself would come to some limits of his experience by the time he died in 1930. Statham's last memorial project with the government at Rangiriri in 1927 also appeared less convincing in its cause for commemoration than those at Ôrākau and Te Ranga over a decade earlier. The incarceration of 183 Māori combatants after the battle seemed to give the commemoration a decidedly less resounding tone of a previous feud between brothers. These later experiences remind us of the fallibility of the narratives put forth by Cowan, Statham and Robley when operating outside of the nexus of memory particular to the timeframe in which it occurred.

As Paul Connerton has explained 'no narrative of modernity as a historical project can afford to ignore its subtext of forgetting. ${ }^{8}$ Connerton's assertion is apparent in the transformations of Cowan and Statham's work after Robley's death in 1930. When Statham revisited the issue of the deterioration of gravestones of settlers and soldiers in Symonds Street cemetery, she sought to apply some of the new Great War memorial styles to the colonial cemetery. Statham shared in the idea that the cemetery be transformed into a memorial park, which demonstrated a desire to ensure an ongoing culture of positive remembrance in the modern, progressive, urban space. However, the scheme was quashed due to sensitivities surrounding the families of those buried in the cemetery, who opposed such a democratising or depersonalising type of remembrance. Cowan's approach was similar. In taking his nostalgic historical episodes to an adolescent audience, Cowan hoped to foster local feeling in the minds of New Zealand's children. In doing so, Cowan had also hoped to install a prominent sense of historical memory in all New Zealanders. But his attempts to create a sense of locality and nativism in his adolescent Pākehā readership tended to promote a forgetting of the conflicts of settlement because of what Māori defiance suggested about the right to claim such territorial belonging.

This thesis has traversed the spatial and temporal landscapes of James Cowan, Edith Statham, and Horatio Gordon Robley's lives and careers within the structure of settler colonialism in New Zealand. This discussion has expanded upon the previous scholarship on memory and forgetting of New Zealand's colonial past. The inclusion of Robley has expanded upon the work of Vincent O'Malley and Kynan Gentry by demonstrating that New Zealand histories were not just produced in New Zealand. ${ }^{9}$ By situating the history-makers work within the logic of settler-colonialism, this thesis has been better able to tease out some of the reasoning as to why the remembering of the New Zealand Wars has fluctuated to this day. ${ }^{10}$ Through an analysis of Cowan, Statham and Robley's publications, manuscripts, monuments, correspondence and newspaper reports, this thesis has incorporated the relevant aspects of their lives and careers into an analysis of their memory and history-making. The period of their collaborative creation of historical memory of the New Zealand Wars between 1914 and 1923, appeared as a contradiction of the forgetfulness of settler colonial societies like New Zealand.

\footnotetext{
${ }^{8}$ Connerton, p. 38.

${ }^{9}$ Gentry, pp. 93-124; O’Malley, The Great War for New Zealand: Waikato 1800-2000, pp. 15-31.

${ }^{10}$ Ibid; Ibid; Macdonald, 'The First World War and the making of Colonial Memory.'
} 
Without purporting to resolve their contradictory nature, this thesis has demonstrated that their nascent histories of this period were a result of a long trajectory of consideration for national or local, and imperial belonging in New Zealand. In observing contextual catalysts of the New Zealand Wars, the Anglo-South African War and the Great War, this thesis has demonstrated the martial and masculine nature of these nascent creations of a New Zealand colonial memory. In doing so, this thesis has touched upon some of the consequences this holds for members of society, whether they are incorporated in such narratives, or excluded from them. This thesis is ultimately a demonstration of the ongoing contention between history and settler colonial progressivism that continues to this day.

In 1934, the Auckland branch of the Victoria League gathered in a room decorated with 'Christmas lilies, red gladioli and blue hyacinths' to honour the first secretary of the outpost, Edith Statham. ${ }^{11}$ In Statham's address to the members of the League she thanked them for the tribute and after outlining her work as inspector of soldiers' graves, implored those present to carry on the duty of upkeep. ${ }^{12}$ Statham continued to be closely affiliated with the League while she was part of Auckland's RSA, drawing on its network in her continued work to keep local cemeteries such as Waikaraka looking tidy. ${ }^{13}$ She also continued to be involved in a wide range of other organisations such as the Waitemata Progress League, the Kohimarama-St. Heliers branch of the WCTU, the Howard League for Prison Reform, the Girl Guides Association and the Plunket Society. ${ }^{14}$ By this time, however, Statham was getting older and starting to slow in her work. In an executive meeting of the Victoria League in 1937, an 84-year-old Statham was noticeably absent from the meeting, reported to be ill. ${ }^{15}$ Statham was back and working by the next year, and executive meeting minutes suggested that the League was supporting her financially during this time. ${ }^{16}$

Statham's activity appeared relatively quiet compared to her extensive engagements prior her tribute by the League. But in 1941, in what appeared to be her last letter to the editor, Statham went out on the same issue that earned her such a reputation. Protesting the unmarked graves at Waikumete Cemetery, Statham wrote in her characteristic way: 'to my mind every man who wore the King's uniform is entitled to have attention given to his last resting place. ${ }^{, 17}$ In 1943, the Victoria League celebrated Statham's $93^{\text {rd }}$ birthday, indicating a change in pace for the ever-energetic Statham. ${ }^{18}$ She

\footnotetext{
11 'Victoria League: Miss Statham Honoured’, NZH, 12 December 1934, p. 6.

12 Ibid.

13 'Soldiers’ Graves’, NZH, 26 September 1935, p. 14.

${ }^{14}$ Society and Crime: Reforms in Treatment', NZH, 26 February 1927, p14; 'Girl Guides Association', NZH, 22 November 1928, p. 7; 'Infant Welfare', NZH, 22 May 1930, p. 16.

15 'Executive Meeting', 23 November 1937, Executive Committee Meeting Minutes 1936-1944, Box 43, NZMS 1244, GGSC.

16 'Executive Meeting', 28 June 1938, 20 September 1938, Executive Committee Meeting Minutes 1936-1944, Box 43, NZMS 1244, GGSC.

${ }^{17}$ Edith Statham, 'Soldiers' Graves', NZH, 24 October 1941, p. 4.

18 'Birthday Party', NZH, 15 April 1943, p. 5.
} 
remained unmarried and not much is known about her personal life. Reports in the New Zealand Herald suggested that Statham had continued to reside with Emily Rigg who she had left Dunedin with in 1901. ${ }^{19}$ Statham died at her home on Gifford St, St. Heliers, on 13 February 1951 at the age of 97. She was described in an obituary in the Otago Daily Times two days later as 'a noted worker in many welfare organisations., $^{20}$

From late 1939 to early 1940, the New Zealand public turned out in droves to the various events and activities that had been designated to celebrate 100 years since the 'birth of the nation' and signing of Treaty of Waitangi. In Wellington, a combination of funds from local council and corporate shareholders was collected and channelled into building an elaborate structure in the suburb of Rongotai to house the New Zealand Centennial Exhibition from November 1939 to May $1940 .{ }^{21}$ The Exhibition boasted historical, artistic and agricultural displays, and even included a full playpark of carnival rides, quite the advancement from the daily remembrance promoted in Edith Statham's 1935 memorial park idea. ${ }^{22}$ The 'keynote' event however, had been the re-enactment of the Treaty signing at Waitangi, where Apirana Ngata appeared front and centre of the proceedings, including leading the Ngati Porou haka at the opening of the whare whakairo on site. ${ }^{23}$

Aside from his Settlers and Pioneers contribution to the Centennial Surveys, James Cowan had little to do with the 1940 celebrations. The purpose of the celebrations, Rachel Barrowman defines, as 'honouring the pioneers, celebrating a century of material progress and government, and about fostering "a proper national pride" in time of war. ${ }^{24}$ The centenary had become a significant cultural event largely through the energies of Under-Secretary of the Department of Internal Affairs, Joseph Heenan. Heenan had spearheaded the 'historical publications programme' as a part of the centennial preparations. In the wake of its success, Heenan established the Historical Branch with John C. Beaglehole as key advisor, continuing a systematic government production of historical works. ${ }^{25}$ Cowan's absence from the new branch was, in part, due to his age and ailing health. He had for the most part of the last decade suffered from rheumatism which made him increasingly immobile. By 1936, this was the reason that the new Labour Government had granted him a $£ 100$ annuity, in what Barrowman suggests was Heenan’s first act of 'cultural patronage. ${ }^{26}$ In 1941, the year of the Historical Branch’s establishment, Cowan's health

\footnotetext{
19 'St.Heliers Bay Notes', NZH, 6 April 1925, p. 10; NZH, 10 March 1931, p. 3.

20 'Obituary', $O D T, 15$ February 1951, p. 9.

${ }^{21}$ Gavin McLean, 'Business as Usual', in William Renwick (ed.), Creating a National Spirit: Celebrating New Zealand's Centennial, (Wellington: Victoria University Press, 2004), p. 25.

${ }^{22}$ Gavin McLean, 'Hurrah for Playland!', William Renwick (ed.), Creating a National Spirit, p. 90.

${ }^{23}$ Barrowman, p. 5; William Renwick, 'Reclaiming Waitangi', in William Renwick (ed.), Creating a National Spirit, p. 108.

${ }^{24}$ Barrowman, p. 5.

${ }^{25}$ Ibid, p. 6.

${ }^{26}$ Ibid, p. 4.
} 
deteriorated rapidly and he moved to Ōtaki Beach hospital where he died in September 1943 at 73 year of age. ${ }^{27}$

Cowan's exclusion from this new wave of professional historical work was, in part age-related, but also primarily due to differences in research style. Cowan's histories located himself within the narrative, which was seen as antithetical to the new professionally qualified generation's assertion of distance between the researcher and the past. ${ }^{28}$ This had also been a cause of his alienation from the field of Māori ethnology, and for good reason. The Board of Māori Ethnological Research had gone from a small operation publishing the backlog of research held by the Polynesian Society, to effectively taking over government-funded research into Māori cultural heritage by the 1930s, prioritising Māori sources and emphasising a more disciplined inclusion of Pākehā scholarship. ${ }^{29}$

Isolated by both his failing health, the new discourses in research and his finances in the wake of the economic downturn, Cowan became despondent in his later years. ${ }^{30}$ Appearing to throw punches from below, this sometimes manifested as criticism of the new generation, including Te Rangi Hīroa (Peter Buck). In a letter to Heenan, Cowan criticised Te Rangi Hīroa for not consulting enough Māori authorities for his publication of Vikings of the Sunrise. ${ }^{31}$ Cowan's melancholy, it has been argued by Roger Blackley, is the mostly likely reason behind an image of Cowan, unearthed by Ariana Tīkao at the Alexander Turnbull Library in 2015. ${ }^{32}$ The photograph of a much younger Cowan with a tà moko, huia feathers and ear pendant drawn over top also includes an inscription in Cowan's handwriting that reads 'brooding over my woes (and $\underline{\text { moko }}$ )' (fig. 10). Blackley argues that the image is indicative of the response to a career fading and consequential depression. ${ }^{33}$ But in this image a contemporary viewer might also reflect on the dichotomy of Cowan's self-resolving histories and the ultimate impact (or lack thereof) of those histories on the historical memory and belonging of Pākehā New Zealand. As Stephen Turner articulates, New Zealand is a land of failed separation, neither fully separate from its imperial ties, nor able to directly confront the negotiation of settlement with Māori, resulting in an 'inarticulate melancholy of place. ${ }^{34}$ This notion might be the most enduring legacy of the nascent histories of Cowan, Statham and Robley.

\footnotetext{
${ }^{27}$ Colquhoun, 'Cowan, James', DNZB, Te Ara.

${ }^{28}$ Belgrave, p. 59.

${ }^{29}$ McCarthy and Tapsell, ‘Te Paori Whakapapa', pp. 87-106.

${ }^{30}$ Blackley, Galleries of Maoriland, p. 239.

${ }^{31}$ J.W. Heenan to James Cowan, 10 May 1939, MS-Papers-0039-01A, ATL.

32 Blackley, Galleries of Maoriland, p. 239.

${ }^{33}$ Ibid.

${ }^{34}$ Turner, p. 23.
} 


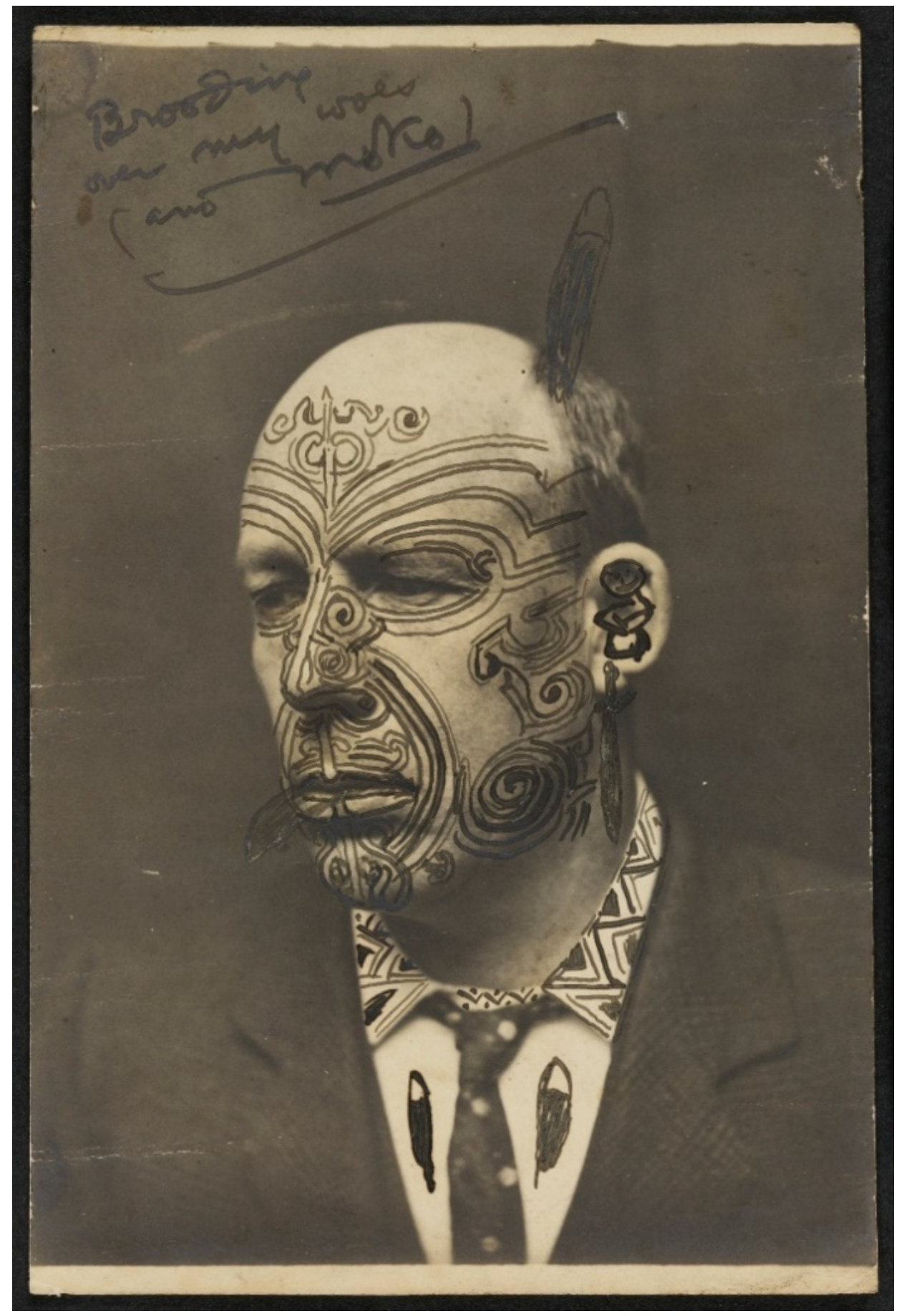

Fig. 10 - 'James Cowan, with a moko drawn in pen’, PAColl-10171, Alexander Turnbull Library, Wellington. 


\section{Bibliography}

\section{Primary Sources}
a) Newspapers

Auckland Star, 1888-1938.

Bay of Plenty Times, 1912, 1923-1924.

Dominion, 1920.

Evening Post, 1902-1934.

Evening Star, 1890-1909.

Gisborne Times, 1926.

Hawera Star, 1934.

Lyttelton Times, 1907, 1914.

New Zealand Herald, 1895-1943.

New Zealand Times, 1902-1907.

Observer, 1894, 1907.

Otago Daily Times, 1875-1951.

Otago Witness, 1895-1900.

Press, 1902-1924.

Thames Star, 1901.

b) Archives

$\underline{\text { Alexander Turnbull Library (ATL) }}$

Best, Elsdon, 1856-1931: Papers, MS-Group-1795, ATL.

'Inward Correspondence - H.G. Robley’, MS-Papers-0072-05A, 'Series 1 - Inwards correspondence’, Series-4710.

Cowan Family: Collection, ATL-Group-00003, ATL. 
‘Correspondence with Jim’s Friends’, MS-Papers-11946-173, 'Correspondence, official documents, and related material', Series-5935.

Cowan, James, 1870-1943: Collection of photographs, PA-Group-00668, ATL.

‘James Cowan, with a moko drawn in pen’, PAColl-10171, ATL.

Cowan, James, 1870-1943: Papers, MS-Papers-0039, ATL.

'Inward Correspondence Re Cowan’s Literary Work’, MS-Papers-0039-03, ‘Series 1

Correspondence', Series-0792.

'Inward Correspondence’, MS-Papers-0039-01A, 'Series 1 Correspondence’, Series-0792.

Cowan, James, 1870-1943: Papers, MS-Group-2097, ATL.

'Correspondence and Papers about Moko', MS-Papers-11310-11, 'Series 1 Correspondence’, Series-5363.

‘Correspondence’, MS-Papers-11310-105, ATL, 'Series 1 Correspondence’, Series-5363.

'Assorted clippings relating to Maori culture and New Zealand history', fMS-Papers-11310184, ‘Series 4 Printed Matter’, Series-5366.

Donne, Thomas Edward 1860-1945: Papers, MS-Group-0028, ATL.

‘Article by Robley’, MS-Papers-1387-14, ‘6 Papers relating to Horatio Robley’, Series-1478.

'Horatio Gordon Robley - Inward Correspondence’, MS-Papers-1387-12, ‘6 Papers relating to Horatio Robley’, Series-1478.

'Horatio Gordon Robley - Outward Correspondence’, MS-Papers-1387-13, ‘6 Papers relating to Horatio Robley', Series-1478.

Hill, Henry Thomas, 1849-1933: Papers, ATL-Group-00435, ATL.

'Inward correspondence - T F Cheeseman, W Petrie, J Drummond and others', MS-Papers0172-010.

Polynesian Society: Records 1845-2011, MS-Group-0677, ATL.

‘Correspondence’, 80-115-04B/01, ‘Correspondence Files’, Series-0233.

‘Correspondence’, 80-115-04B/07, ‘Correspondence Files’, Series-0233.

Robley, Horatio Gordon 1840-1930: Correspondence relating to Maori customs, especially tattooing, Maori sketches, plan of Gate Pa, tattoo patterns etc, MS-Papers-0016, ATL. 
‘Hon. R. Seddon’, ca. 1890, E-280-001.

‘[Robley, Horatio Gordon], 1840-1930 :[Hei-tiki. ca 1900]’, E-280-017-1.

‘[Robley, Horatio Gordon], 1840-1930 :[Maori carving. ca 1900]’, E-280-005.

'Sketches', MS-Papers-0016-03.

Robley, Horatio Gordon, 'Paul Kruger, president of the Transvaal, drawn with Māori facial tattoo’, A080-025, ATL.

Smith, Sydney Charles, 1888-1972: Photographs of New Zealand, PA-Group-00242, ATL.

‘Carillon Dedication’, 25 April 1932, 1/1-020293-G.

\section{Archives New Zealand (ANZ)}

'Departmental - Records - Historical - Appointment of Mr. J. Cowan’, ACGO 8333, Series IA1, Box 1280, Record 4/2/13, ANZ.

'Folder of notes and papers relating to Maori War and Historical Cemeteries, Graves and Memorials', ACGO 8398, Series IA 76, Box 1, Item 1, ANZ.

'National War Memorial, Art Gallery and Dominion Museum 1928-1934', ADRK 17391, Record Group T1, Box 359, Record 52/546, ANZ.

'Outwards Letterbook - High Commissioner 1905-1913’, ACGO 8336, IA4, Box 168, Item 171, ANZ.

'Photograph Album - New Zealand War Graves - Inspection of Graves', ACGO 8396, IA 76, Box 5, Item 29, ANZ.

'War Graves - Cemeteries Auckland District - Care of - Inspection by Miss E.M. Statham', ACGO 8333, IA1, Box 1661, Record 32/1/26, Part 1, ANZ.

'War Graves - Cemeteries Auckland District - Care of - Inspection by Miss E.M. Statham', ACGO 8333, IA1, Box 1661, Record 32/1/26, Part 2, ANZ.

'War Graves - Cemetery - Symonds St', ACGO 8333, IA1 W 1893, Box 3, Record 7/4/11, ANZ.

‘War Graves - King Tāwhiao’, ACGO 8333, IA1, Box 1294, Record 7/4/69, ANZ.

'War Graves - Maori Guide (Sophia) Rotorua', ACGO 8333, IA1, Box 1294, Record 7/4/75, ANZ.

‘War Graves - Monthly and General Reports’, ACGO 8333, IA1, Box 1287, Record 7/4/2, ANZ. 
'War Graves - Orakau’, ACGO 8333, IA1, Box 1292, Record 7/4/38, ANZ.

J.C. Beaglehole Special Collections, Victoria University of Wellington Library (JCBR)

Fildes Collection

‘Autobiographical notes by Maj.-Gen. H. Robley’, Box 22, FILD00057, JCBR.

Fildes, Horace, 'Major General H. Gordon Robley, Soldier and Artist. Sketches in an Army

Career of Thirty Years and after', 1921, Fildes MSS 1507, Folder 1, JCBR.

'Mair, Gilbert, 18 Nov 1920 - 8 Jun 1923’, FILD00027, JCBR.

'Miscellaneous MSS notes and photographs concerning Major-General Robley’, Fildes MSS 1507, Folder 2, JCBR.

'Notebook containing autobiographical notes by Maj.-Gen. H. Robley’, Box 22, FILD00056, JCBR.

'Robley, H. G. (Major-General)’, 1919, Box 10, FILD0035a, JCBR.

'Robley, H. G. (Major-General)', 1920, Box 10, FILD00035b, JCBR.

'Robley, H. G. (Major-General)’, 1921, Box 10, FILD0035c, JCBR.

\section{Sir George Grey Special Collections, Auckland Libraries (GGSC)}

Carr Rollett, Hilda, 'Report to the President and Members of the Victoria League', 6 March 1911, 'Early reports, minutes, etc.', NZMS, Box 43, GGSC.

‘Edith Mary Statham’, Ref. File 438, GGSC.

Ephemera (Loose), Boxes 1, 4, 14, 15, NZMS 1244, GGSC.

'Executive Committee Meeting Minutes 1936-1944’, Box 43, NZMS 1244, GGSC.

'First Minute Book, 1909-1918’, 18 November 1909, NZMS 1244, Box 43, GGSC.

'Reports of the Branches: Auckland', Victoria League: Report of the Fourth Dominion Conference, 24-25 November, 1925, NZMS 1244, Box 37, GGSC. 
Richardson, James D., 'War memorial on the corner of Wakefield and Symonds Street, Auckland', Ref. 4-3393, GGSC.

Statham, Edith, 'Report to the Council', 24 June 1913, Box 43, NZMS 1244, GGSC.

Statham, Edith, 'Report to the President and Members of the Victoria League', 7 March 1912, Box 43, NZMS 1244, GGSC.

'To be Erected in Auckland: The Victoria League’s Memorial to Sailors and Friendly Natives who fell in the Maori Wars', 18 June 1914, AWNS-19140618-40-4, GGSC.

\section{$\underline{\text { Te Awamutu Museum }}$}

'Orakau 50 ${ }^{\text {th }}$ Anniversary’, 01 April 1914, PH1497.

\section{Te Papa Tongarewa}

Robley, Horatio Gordon, 'No 3 Gate Maketu Pa’, 1865, Reg. no. 1992-0035-1892, Te Papa Collections; https://collections.tepapa.govt.nz/object/98620; accessed 16 April 2021.

\section{c) Published}

Andersen, Johannes, 'Obituary: Horatio Gordon Robley, 1840-1930', The Journal of the Polynesian Society, Vol. 40, No. 1, March 1931, pp. 39-46.

Banks, Joseph, J.C. Beaglehole (ed.), The Endeavour Journal of Joseph Banks 1768-1771, Vol. I, (Sydney: Halstead Press, 1962).

Cowan, James, Adventures of Kimble Bent, (Christchurch: Whitcombe and Tombs, 1911).

Cowan, James, Hero Stories of New Zealand, (Wellington: Harry H. Tombs Ltd, 1935).

Cowan, James, Maori Biographies, Sketches of Old New Zealand, (Auckland: Brett Publishing Co., 1901).

Cowan, James, New Zealand or Ao-tea-roa, (Wellington: Dept. of Tourist and Health Resorts, 1908). 
Cowan, James, Romance of the Rail: Through the Heart of New Zealand: The North Island Main Trunk Railway: A Descriptive and Historical Story, (Wellington: Govt. Printer, 1928).

Cowan, James, Samoa and its Story, (Christchurch: Whitcombe and Tombs, 1914).

Cowan, James, Settlers and Pioneers, (Wellington: Department of Internal Affairs, 1940).

Cowan, James, Tales of the Maori Bush, (Christchurch: Whitcombe and Tombs, 1934).

Cowan, James, The Maori: Yesterday and To-Day, (Christchurch: Whitcombe \& Tombs, 1930).

Cowan, James, The Maoris in the Great War; A History of the Native Contingent and Pioneer

Battalion Gallipoli 1915, France and Flanders, 1916-1918, (Auckland: Maori Regimental

Committee, 1926).

Cowan, James, The New Zealand Wars: A History of the Maori Campaign and the Pioneering Period, Vol. 1, $3^{\text {rd }}$ ed. (Wellington: Govt. Printer, 1983).

Cowan, James, The New Zealand Wars: A History of the Maori Campaigns and the Pioneering Period, Vol. II, $3^{\text {rd }}$ ed. (Wellington: Govt Printer, 1983).

Cowan, James, The Old Frontier: Te Awamutu, The Story of the Waipa Valley, (Te Awamutu: Waipa Post and Publishing Company, 1922).

Pember Reeves, William, The Long White Cloud - Ao Tea Roa, (London: Horace Marshall and Son, 1898).

Robley, Horatio Gordon, Moko; or Maori Tattooing, (London: Chapman and Hall, 1894).

Robley, Horatio Gordon, Pounamu - Notes on New Zealand Greenstone, (London: T.J.S. Guilford \& Co., 1915).

Victoria League Tenth Annual Report 1911-12, (London: Victoria League, 1912).

\section{d) Appendices to the Journal of the House of Representatives (AJHR)}

'Maori Antiquities Act 1901', AJHR, 1901, Session I, G-08, p. 1.

Thomson, J. Allan, Hogben, G., 'Organization of Scientific and Industrial Research', AJHR, 2

October 1917, Session I, H-47, p. 7. 


\section{e) Legislation}

Auckland (Symonds Street) Cemeteries Act 1908, 8 EDW VII, No. 12;

http://www.nzlii.org/nz/legis/hist_act/asca19088ev1908n12486/; accessed 22 May 2021.

Science and Art Act 1913, 4. GEO. V. No. 22;

http://www.nzlii.org/nz/legis/hist_act/saaa19134gv1913n22196/; accessed 26 January 2021.

New Zealand Institute Act 1867, No. 36; http://nzlii.org/nz/legis/hist_act/nzia186731v1867n36364/; accessed 19 May 2021.

\section{Secondary Sources}

\section{a) Books}

Anderson, Benedict, Imagined Communities, Revised Edition (London: Verso, 2006).

Ballantyne, Tony, Webs of Empire: Locating New Zealand's Colonial Past, (Wellington: Bridget Williams Books, 2012).

Barnes, Felicity, New Zealand's London: A Colony and its Metropolis, (Auckland: Auckland University Press, 2012).

Belich, James, Paradise Reforged, (London: Penguin Books, 2002).

Belich, James, The New Zealand Wars and the Victorian Interpretation of Racial Conflict, (Auckland: Auckland University Press, 1986).

Bell, Leonard, Colonial Constructs: European Images of Maori, 1840-1914, (Auckland: Auckland University Press, 1992).

Brooking, Tom, Richard Seddon: King of God's Own, (London: Penguin Books, 2014).

Connerton, Paul, The Spirit of Mourning: History, Memory and the Body, (Cambridge: Cambridge University Press, 2011).

Crawford, John and Ellen Ellis, To Fight for the Empire, (Auckland: Reed Books, 1999).

Cross, Nigel, The Common Writer: Life in Nineteenth Century Grub Street, (Cambridge: Cambridge University Press, 1985). 
Gentry, Kynan, History, Heritage, and Colonialism, (Manchester: Manchester University Press, 2015).

Grant, Ian, Lasting Impressions: The Story of New Zealand's Newspapers 1840-1920, (Masterton: Fraser Books, 2018).

Hastings, David, Extra! Extra!: How People Made the News, (Auckland: Auckland University Press, 2013).

Hilliard, Chris, The Bookmen’s Dominion, (Auckland: Auckland University Press, 2006).

King, Michael, Being Pakeha Now, (Auckland: Penguin Books, 1999).

King, Michael, Te Puea: A Biography, Rev. Ed. (Auckland: Hodder and Stouton, 1978).

Lake, Marilyn, Progressive New World: How Settler Colonialism and Transpacific Exchange Shaped American Reform, (London: Harvard University Press, 2019).

Lawlor, Pat, Old Wellington Days, (Wellington: Whitcombe \& Tombs, 1959).

McCarthy, Conal, Exhibiting Maori: A History of Colonial Cultures on Display, (Oxford: Berg, 2007).

McClure, Margaret, The Wonder Country: Making New Zealand Tourism, (Auckland: Auckland University Press, 2004).

Melvin, Les W., Horatio Gordon Robley: Soldier Artist in the Bay of Plenty 1864-1866, 2nd ed. (Tauranga: Tauranga Historical Society, 1990).

Newstead Simmons, Alma, Fifty Years of the Victoria League in Auckland, New Zealand 1910-1960:

Golden Jubilee Year, (Auckland: Pelorus Press, 1960).

Nora, Pierre, Rethinking France: Les Lieux de Memoire, Revised Edition (Chicago: Chicago Press, 2001).

O’Malley, Vincent, The Great War for New Zealand: Waikato 1800-2000, (Wellington: Bridget Williams Books, 2016).

O’Malley, Vincent, The New Zealand Wars, Ngā Pakanga o Aotearoa, (Wellington: Bridget Williams Books, 2019).

Olssen, Erik, A History of Otago, (Dunedin: John McIndoe, 1984).

Petrie, Hazel, Chiefs of Industry, (Auckland: Auckland University Press, 2006). 
Phillips, Jock and Chris Maclean, The Sorrow and the Pride, (Wellington: Department of Internal Affairs, 1990).

Phillips, Jock, To the Memory: New Zealand's War Memorials, (Nelson: Potton and Burton, 2016).

Pickles, Katie, Female Imperialism and National Identity, (Manchester: Manchester University Press, 2002).

Reese-Jones, Margaret, Printer's Progress: A New Zealand Newspaper Story 1840-2014, (Gisborne: Gisborne Herald Co. Ltd., 2015).

Samuel, Raphael, Theatres of Memory, Volume I: The Past and Present in Contemporary Culture, (London: Verso, 1994).

Stafford, Jane and Mark Williams, Maoriland: New Zealand Literature, (Wellington: Victoria University Press, 2006).

State Services Commission, The Journey of the Treaty, (Wellington: 2005).

Stokes, Bertram O., A History of the Victoria League for Commonwealth Friendship in New Zealand, (Auckland: The League, 1979).

Thomas, Nicholas, In Oceania: Visions, Artifacts, Histories, (Durham: Duke University Press, 1997).

Tuhiwai-Smith, Linda, Decolonising Methodologies: Research and Indigenous Peoples, (Dunedin: Otago University Press, 1999).

Veracini, Lorenzo, The Settler Colonial Present, (London: Palgrave Macmillan, 2015).

Winter, Jay, Remembering War: The Great War Between Memory and History in the $20^{\text {th }}$ Century, (New Haven: Yale University Press, 2006).

Wood, Pamela, Dirt: Filth and Decay in a New World Arcadia, (Auckland: Auckland University Press, 2005).

\section{b) Chapters in Edited Collections}

Brookes, Barbara, 'The Risk to Life and Limb: Gender and Health', in Barbara Brookes, Annabel Cooper, and Robin Law, (eds.), Sites of Gender: Women, Men and Modernity in Southern Dunedin, 1890-1939, (Auckland: Auckland University Press, 2003).

Brookes, Barbara, Erik Olssen and Emma Beer, 'Spare Time? Leisure, Gender and Modernity', in Barbara Brookes, Annabel Cooper, and Robin Law, (eds.), Sites of Gender: Women, Men and Modernity in Southern Dunedin, 1890-1939, (Auckland: Auckland University Press, 2003). 
Cooper, Annabel, Erik Olssen, Kirsten Thomlinson and Robin Law, 'The Landscape of Gender Politics: Place, People and Two Mobilisations', in Barbara Brookes, Annabel Cooper, and Robin Law, (eds.), Sites of Gender: Women, Men and Modernity in Southern Dunedin, 1890-1939, (Auckland: Auckland University Press, 2003).

King, Michael, 'Introduction', in James, Cowan, The New Zealand Wars: A History of the Maori Campaigns and the Pioneering Period, Vol. II, $3^{\text {rd }}$ ed. (Wellington: Govt Printer, 1983).

McLean, Gavin, 'Business as Usual: Managing and Funding the Centennial Exhibition', in William Renwick (ed.), Creating a National Spirit: Celebrating New Zealand's Centennial, (Wellington: Victoria University Press, 2004).

McLean, Gavin, 'Hurrah for Playland!', in William Renwick (ed.), Creating a National Spirit: Celebrating New Zealand's Centennial, (Wellington: Victoria University Press, 2004).

Olssen, Erik, 'Working Gender, Gendering Work: Occupational change and Continuity in Southern Dunedin', in Barbara Brookes, Annabel Cooper, and Robin Law, (eds.), Sites of Gender: Women, Men and Modernity in Southern Dunedin, 1890-1939, (Auckland: Auckland University Press, 2003).

Renwick, William, 'Reclaiming Waitangi', in William Renwick (ed.), Creating a National Spirit: Celebrating New Zealand's Centennial, (Wellington: Victoria University Press, 2004).

Sinnreich, Richard Hart, ‘An Army Apart’, in Peter R. Mansoor, (ed), The Culture of Military Organisations, (Cambridge: Cambridge University Press, 2019).

Turner, Stephen, 'Settlement as Forgetting', in Klaus Neumann, Nicholas Thomas, and Hilary Ericksen, (eds.), Quicksands: Foundational histories in Australia and Aotearoa New Zealand, (Sydney: University of New South Wales Press, 1999).

Veracini, Lorenzo, 'Telling the End of the Settler Colonial Story', in Fiona Bateman, and Lionel Pilkington (eds.), Studies in Settler Colonialism: Politics, Identity and Culture, (London: Palgrave Macmillan, 2011).

Wolfe, Patrick, 'Islam, Europe and Indian Nationalism: Towards a Postcolonial Transnationalism', in Ann Curthoys and Marilyn Lake (eds), Connected Worlds: History in Transnational Perspective, (Canberra: ANU E-Press, 2005). 


\section{c) Articles}

Adams, Tui, Ngahinaturae Te Uira and Ann Parsonson, 'Behold a Kite that Flies Towards You: the Kingtanga and the 'Opening' of the King Country', New Zealand Journal of History, Vol. 31, No. 1, 1997, pp. 99-116.

Barrowman, Rachel, “'Culture-organising' Joe Heenan and the beginnings of state patronage of the arts', Journal of New Zealand Studies, Vol. 6, No. 2, 1996, pp. 3-10.

Belich James, 'Myth, Race and Identity in New Zealand', New Zealand Journal of History, Vol. 31, 1997, pp. 9-22.

Bell, Avril 'Bifurcation or Entanglement? Settler Identity and Biculturalism in Aotearoa New Zealand', Continuum, Vol. 20, No. 2, 2006, pp. 253-268.

Blackley, Roger, 'The Plutarch of Maoriland: James Cowan and Pictures of Old New Zealand', Journal of New Zealand Studies, Vol. 19, 2015, pp. 111-123.

Bush, Julia, 'Edwardian Ladies and the "Race" Dimensions of British Imperialism', Women's Studies International Forum, Vol. 21, No. 3, 1998, pp. 277-289.

Coleborne, Catharine and Ondine Godtschalk, 'Colonial Families and Cultures of Health: Glimpses of Illness and Domestic Medicine in Private Records in New Zealand and Australia, 1850-1910', Journal of Family History, Vol. 38, No. 4, 2013, pp. 403-421.

Cooper, Annabel, 'No Ōrākau: Past and People in James Cowan’s Places’, Journal of New Zealand Studies, No. 19, 2015, pp. 63-78.

Georgiou, Dion, 'Restaging Mafeking in Muswell Hill: Performing Patriotism and Charitability, Historical Research, Vol. 91, No. 254, 2018, pp. 744-771.

Gibbons, Peter, ‘Cultural Colonisation and National Identity’, New Zealand Journal of History, Vol. 36, No. 1, 2002, pp. 5-17.

Hillard, Chris, 'Stories of an Era not yet so very Remote: James Cowan in and out of New Zealand History’, Journal of New Zealand Studies, No. 19, 2015, pp. 28-39.

Hokowhitu, Brendan, 'Producing Elite Indigenous Masculinities', Settler Colonial Studies, Vol. 2, No. 2, 2012, pp. 23-48.

Hokowhitu, Brendan, ‘The Death of Koro Paka: “Traditional” Māori Patriarchy', The Contemporary Pacific, Vol. 20, No. 1, 2008, pp. 115-141.

Hokowhitu, Brendan and Tiffany Page, 'Post-Colonial Peace', Junctures, Vol. 14, 2011, pp. 13-25. 
Hunter, Kathryn, 'National and Imperial Belonging in Wartime: The Tangled Knot of Australians and New Zelanders as British Subjects during the Great War', Australian Journal of Politics and History, Vol. 63, No. 1, 2017, pp. 31-44.

Hunter, Kathryn, “'Sleep on dear Ernie, your battles are o’er’: A Glimpse of a Mourning Community, Invercargill, New Zealand, 1914-1925’, War in History, Vol. 14, No, 1, 2007, pp. 36-62.

Kēhaulani Kauanui, J., ““A Structure, Not an Event”: Settler Colonialism and Enduring Indigeneity’, Lateral, Iss. 5, No. 1, 2016.

Kiersnowska, Beata, 'Female Cycling and the Discourse of Moral Panic in Late Victorian Britain', Journal of the Spanish Association of Anglo-American Studies, Vol. 41, No. 2, 2019, pp. 85-103. Loveridge, Steven, “"Soldiers and Shirkers”: Modernity and New Zealand Masculinity During the Great War', New Zealand Journal of History, Vol. 47, No. 1, 2013, pp. 59-79.

Macdonald, Charlotte, ‘The First World War and the making of Colonial Memory', Journal of New Zealand Literature, Vol. 33, No. 2, 2015, pp. 15-37.

Macdonald, Charlotte, 'Woolwich to Wellington: From Settler Colony to Garrisoned Sovereignty', New Zealand Journal of History, Vol. 53, No. 1, 2019, pp. 50-76.

Maguire, Anna, 'Looking for Home? New Zealand Soldiers Visiting London During the First World War', The London Journal, Vol. 41, No. 3, 2016, pp. 281-298.

Mahuika, Nēpia, “Closing the Gaps': From Postcolonialism to Kaupapa Maori and Beyond', New Zealand Journal of History, Vol. 46, No.1, 2011, pp. 15-32.

McCarthy, Conal, “"Empirical Anthropologists Advocating Cultural Adjustments”: The Anthropological Governance of Āpirana Ngata and the Native Affairs Department', History and Anthropology, Vol. 25, No. 2, 2014, pp. 280-295.

McCarthy, Conal, and Paul Tapsell, 'Te Paori Whakapapa: The Origins, Operation and Tribal Networks of the Board of Maori Ethnological research 1923-1935', Journal of the Polynesian Society, Vol. 128, No. 1, 2019, pp. 87-106.

McGibbon, Ian, 'New Zealand’s First Conquest', New Zealand International Review, Vol. 39, No. 1, 2014, p. 18.

Meredith, Paul, 'Tēnā koe Hēmi Kāwana: A Ngāti Maniapoto Half-Caste from Kihikihi Greets James Cowan', Journal of New Zealand Studies, Vol. 19, 2015, pp. 5-15.

Nora, Pierre, 'Between Memory and History: Les Lieux de Mémoire’, Representations, No. 26, 1989, pp. 7-24. 
Parsons, Kathryn, ““A Famous Writer Coles to Our Pages”: James Cowan's Children’s Writing for the Enzed Junior’, Journal of New Zealand Studies, No. 19, 2015, pp. 98-110.

Pickles, Katie, “"A link in 'the great chain of Empire friendship”: the Victoria League in New Zealand', The Journal of Imperial and Commonwealth History, Vol. 33, No. 1, 2005. pp. 29-50.

Pishief, E., 'Augustus Hamilton’s “scientific specimens or 'Maori Art”: agency and the social life of things', Journal of the Royal Society of New Zealand, Vol. 47, No. 1, 2017, pp. 132-137.

Rice, Rebecca ‘The ‘Gordon Collection’ of Photographic Portraits Relating to the New Zealand Wars', New Zealand Journal of History, Vol. 52, No. 1, 2018, pp. 41-68.

Sargison, Patricia, 'Gender, Class, and Power: Ideologies and conflict during the transition to trained female nursing at two New Zealand hospitals, 1889-95', Women’s History Review, Vol. 6, No. 2, 1997, pp. 165-178.

Tau, Te Maire, 'I-nga-ra-o-mua’, Journal of New Zealand Studies, Vol. 10, 2011, pp. 45-62.

Tîkao, Ariana, ‘Borderland: From Archive to Gallery: Working on James Cowan's Papers', Journal of New Zealand Studies, No. 19, 2015, pp. 16-27.

Veracini, Lorenzo, 'Historylessness: Australia as a Settler Colonial Collective', Postcolonial Studies, Vol. 10, No. 2, 2007, pp. 271-285.

Walker, Franchesca, “'Descendants of a Warrior Race’: The Maori Contingent, New Zealand Battalion, and Martial Race Myth’, War \& Society, Vol 31, No. 1, 2012, pp. 1-21.

Wevers, Lydia, ‘Being Pakeha: The Politics of Location', Journal of New Zealand Studies, No. 4, October 2005, pp. 1-9.

Wevers, Lydia, 'Romance of the Rail', Journal of New Zealand Studies, Vol. 19, 2015, pp. 40-49.

Wolfe, Patrick, 'Settler Colonialism and the Elimination of the Native', Journal of Genocide Research, Vol. 8, No. 4, 2006, pp. 387-409.

Worthy, Scott, 'Communities of Remembrance: making Auckland's War Memorial Museum', Journal of Contemporary History, Vol. 39, No. 4, 2004, pp. 588-618.

\section{d) Theses}

Hilliard, Chris, 'Island Stories: The Writing of New Zealand History’, MA thesis, Auckland University, 1997. 
Loveridge, Steven, 'Sentimental Equipment: New Zealand, the Great War and Cultural Mobilisation', PhD thesis, Victoria University of Wellington, 2013.

Walker, Timothy, ‘Robley: Te Ropere 1840-1930’, MA thesis, Auckland University, 1985.

Wood, Greg, 'Revisiting James Cowan: a reassessment of the New Zealand Wars (1922-23)', MA thesis, Auckland University, 2010.

Whiting, Lydia, 'Memories of the Masculine: James Cowan and the Homogenising of a New Zealand Collective Memory’, BA(Hons) research essay, Victoria University of Wellington, 2019.

\section{e) Te Ara - Encyclopedia of New Zealand}

Ballara, Angela, 'Patuone, Eruera Maihi', DNZB, Te Ara, 1990, updated 2010;

https://teara.govt.nz/en/biographies/1p12/patuone-eruera-maihi; accessed 3 July 2021.

Colquhoun, David, 'Cowan, James', DNZB, Te Ara, 1996, updated 2012;

https://teara.govt.nz/en/biographies/3c36/cowan-james; accessed 27 April 2021.

Crawford, J. A. B., 'Porter, Thomas William', DNZB, Te Ara, 1993;

https:/teara.govt.nz/en/biographies/2p26/porter-thomas-william; accessed 4 July 2021.

Curnow, Jenifer, 'Hinerangi, Sophia', DNZB, Te Ara, 1993, updated 2015;

https://teara.govt.nz/en/biographies/2h37/hinerangi-sophia; accessed 23 July 2021.

Derby, Mark, 'Strikes and labour disputes - Early labour disputes', Te Ara, 2011;

http://www.TeAra.govt.nz/en/strikes-and-labour-disputes/page-2; accessed 20 June 2021.

Phillips, Jock, 'Men’s clubs', Te Ara, 2011, updated 2018; http://www.TeAra.govt.nz/en/mens-

clubs/print; accessed 2 June 2021.

Phillips, Jock, 'Statham, Edith Mary', DNZB, Te Ara, 1996;

https://teara.govt.nz/en/biographies/3s32/statham-edith-mary; accessed 15 May 2021.

Pollock, Kerryn, 'King Country region - Te Rohe Pōtae', Te Ara, 2011, updated 2015;

http://www.TeAra.govt.nz/en/king-country-region/page-6; accessed 28 June 2021.

Renwick, William, 'Combs, Frank Livingstone', DNZB, Te Ara, 1998;

https://teara.govt.nz/en/biographies/4c27/combs-frank-livingstone; accessed 22 May 2021. 
Wikaira, Martin, 'Ngāti Tūwharetoa - Lands and people', Te Ara - the Encyclopedia of New Zealand, 2005, updated 2017; http://www.TeAra.govt.nz/en/ngati-tuwharetoa/page-1; accessed 3 July 2021.

\section{f) Electronic Sources}

Yang Maya, Oliver Milman, 'Charlottesville removes Confederate statues that helped spark deadly rallies', The Guardian, 10 July 2021; https://www.theguardian.com/us-

news/2021/jul/10/charlottesville-statue-; accessed 13 July 2021.

'National Repatriation Policy for Kōiwhi Tangata and Associated Burial Taonga within Aotearoa', Museums Aotearoa, 24 June 2021;

https://www.museumsaotearoa.org.nz/publications/repository/national-repatriation-policy-koiwitangata-and-associated-burial-taonga; accessed 13 June 2021.

“'Stop immortalising a legacy of murder': Which NZ statues need to be toppled?', The Spinoff: 12 June 2020; https://thespinoff.co.nz/atea/12-06-2020/stop-immortalising-a-legacy-of-murder-whichnz-statues-need-to-be-toppled/; accessed 13 July 2021. 